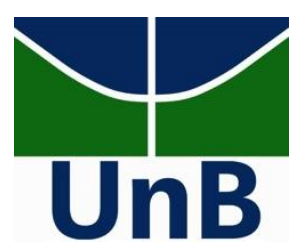

Universidade de Brasília

Faculdade UnB Planaltina

Programa de Pós-Graduação em Gestão Pública

Mestrado Profissional em Gestão Pública

AÇÕES AFIRMATIVAS PARA A POPULAÇÃO NEGRA EM PROGRAMAS DE PÓS- GRADUAÇÃO: APROFUNDANDO A QUESTÃO DA UNIVERSIDADE DE BRASÍLIA

RIVANY BORGES BEÚ

Brasília - DF

2015 


\title{
AÇÕES AFIRMATIVAS PARA A POPULAÇÃO NEGRA EM PROGRAMAS DE PÓS-GRADUAÇÃO: APROFUNDANDO A QUESTÃO DA UNIVERSIDADE DE BRASÍLIA
}

\author{
Dissertação apresentada ao Programa de Pós- \\ graduação em Gestão Pública (PPGP), da Faculdade \\ UnB Planaltina (FUP), Universidade de Brasília \\ (UnB) como requisito parcial para obtenção do título \\ de Mestre em Gestão Pública.
}

Orientadora: Professora Doutora Andréa de Oliveira Gonçalves

Brasília - DF

2015 
Ficha catalográfica elaborada automaticamente, com os dados fornecidos pelo(a) autor(a).

Beú, Rivany Borges
Ações afirmativas para a população negra em programas de pós-
graduação stricto sensu:aprofundando a questão na universidade de
Brasília /
Rivany Borges Beú; orientador Andréa de Oliveira Gonçalves. --
Brasília, $2015.170 \mathrm{p}$.
Dissertação (Mestrado - Mestrado Profissional em Gestão
Pública) -- Universidade de Brasília, 2015.
1. I. Gonçalves, Andréa de Oliveira, orient.
TÍtulo.




\title{
AÇÕES AFIRMATIVAS PARA A POPULAÇÃO NEGRA EM PROGRAMAS DE PÓS-GRADUAÇÃOO: APROFUNDANDO A QUESTÃO DA UNIVERSIDADE DE BRASÍLIA
}

\author{
Dissertação apresentada ao Programa de Pós- \\ Graduação em Gestão Pública (PPGP), da Faculdade \\ UnB Planaltina (FUP), Universidade de Brasília \\ (UnB), como requisito parcial para obtenção do título \\ de Mestre em Gestão Pública.
}

Aprovada em:

Banca examinadora:

Professora Doutora Andréa de Oliveira Gonçalves - Orientadora

Programa de Pós-Graduação em Gestão Pública - Universidade de Brasília

Professora Doutora Denise Bomtempo Briche de Carvalho - Membro Externo

Programa de Pós-Graduação em Serviço Social - Universidade de Brasília

Professor Doutor Marcelo Carvalho Rosa - Membro Externo

Programa de Pós-Graduação em Sociologia - Universidade de Brasília

Professora Doutora Maria Raquel Gomes Maia Pires - Suplente

Programa de Pós-Graduação em Gestão Pública - Universidade de Brasília 
Aos meus amados filhos. Que este trabalho, um dia, lhes inspire a buscarem o conhecimento científico. 


\section{AGRADECIMENTOS}

É com o sentimento de dever cumprido que agradeço primeiramente a Deus por ser a razão maior de existência.

Ao meu amado e dedicado esposo, vão os agradecimentos mais que especiais pela cumplicidade ao longo dessa jornada, cujo o apoio foi fundamental.

Aos meus filhos amados agradeço o amor puro que trocamos diariamente, fonte de inspiração que me motivou a persistir.

Aos meus pais, os agradecimentos serão eternos por me darem o elemento que originou tudo isso, a vida. Ao padrasto também agradeço sua parcela de contribuição.

À minha orientadora Andréa de Oliveira Gonçalves que soube conduzir a construção desta Dissertação, compreendendo as adversidades e os dilemas vividos pela mulher contemporânea, meus agradecimentos carinhosos.

Por contribuir com o conhecimento adquirido ao longo do curso, agradeço aos professores que carregam em seus ombros a responsabilidade de desempenhar um dos papéis mais importantes na sociedade: a educação.

Aos queridos colegas da primeira turma (2/2013) do PPGP, agradeço a participação, a compreensão, o companheirismo, a paciência, os ensinamentos e muito mais coisas que agregaram para o curso e para a meu crescimento. Sem vocês, teria sido muito mais difícil.

Aos meus colegas de trabalho, agradeço por compreenderem os momentos atribulados, ao Valdeci pelas liberações e, especialmente, à Marcia Abrahão pelo apoio sempre expresso, e pela confiança.

À Universidade de Brasília, agradeço pelo apoio financeiro, pela oportunidade dada aos seus servidores em avançar na vida acadêmica com qualidade. 
"Somos o que repetidamente fazemos. A excelência, portanto, não é um feito, mas um hábito" 


\title{
AÇões AFIRMATIVAS PARA A POPULAÇÃo NEGRA EM PROGRAMAS DE PÓS- GRADUAÇÃO: APROFUNDANDO A QUESTÃO DA UNIVERSIDADE DE BRASÍLIA
}

\begin{abstract}
RESUMO
No setor da educação superior brasileira o governo vem buscando implantar políticas públicas de ações afirmativas com o objetivo de ampliar o acesso da população negra como respostas a lacunas sociais. A Universidade de Brasília ganhou importância nesse cenário em razão de sua participação nas discussões sobre as questões que circundam esse tipo de política pública e pela visibilidade dada às ações afirmativas, ao implantar o modelo de sistema de cotas na graduação em 2004, tornando-se pioneira no âmbito federal. O estabelecimento da chamada "Lei das Cotas", em 2012, representou a consolidação dessa política pública no âmbito federal. Nos anos seguintes, surgiram iniciativas em algumas universidades públicas federais, sugerindo uma tendência de ampliação do sistema de cotas para a pós-graduação stricto sensu em 2015. A Universidade de Brasília figura entre as instituições de ensino superior como uma das pioneiras nesse tipo de ação ao implantar políticas de ações afirmativas em quatro programas de pós-graduação stricto sensu. Em 2014, o governo sinalizou um incentivo a essa tendência, ao estipular a meta 14.5 do Plano Nacional de Educação, colocando o desafio de aumentar o percentual de negros mestres e doutores no Brasil. Nesse contexto, esta Dissertação tem relevância por proporcionar novas discussões sobre um tema pouco explorado, e por contribuir para as fases de uma política pública, uma vez que se propõe analisar as ações de ampliação ao acesso da população negra a programas de pós-graduação stricto sensu da Universidade de Brasília entre 2004 a 2015. É uma pesquisa qualitativa e exploratória que para alcançar o objetivo foi estabelecido um percurso metodológico que incluiu a definição das técnicas de coleta e de análise de dados que melhor se adequassem ao alcance dos objetivos específicos. As técnicas de coleta de dados foram a pesquisa documental e as entrevistas semiestruturadas. As técnicas de análise de dados foram a análise de conteúdo e a análise documental. Foram definidas duas dimensões da pesquisa e quatros categorias teóricas ex-ante, as quais refletem os objetivos específicos. Essa estrutura guiou as definições seguintes, como a elaboração das perguntas de pesquisa. Dessa forma, ao final da análise, foram definidas quatro categorias finais as quais representam resultados dos objetivos específicos. Os resultados demonstram que a UnB tem sido omissa com a não existência da política institucional de ampliação ao acesso da população negra nos cursos de pós-graduação stricto sensu, sendo que quatro unidades acadêmicas seguem na vanguarda com suas iniciativas isoladas, possível pela autonomia regulamentar que dispõem. Os resultados confirmam a hipótese diretriz de que o esforço da Universidade de Brasília para a institucionalização da ação afirmativa na pós-graduação stricto sensu não ocorre na mesma medida das pressões de grupos como estudantes e do próprio governo, embora as pressões estejam norteando agendas governamentais.
\end{abstract}

Palavras-chave: Ampliação ao acesso, população negra, política pública, ação afirmativa. pós-graduação stricto sensu. 


\title{
AFFIRMATIVE ACTIONS FOR BLACK POPULATION IN POSTGRADUATE PROGRAMS: DEEPENING THE QUESTION IN THE UNIVERSITY OF BRASILIA
}

\begin{abstract}
The Brazilian Government has been seeking to establish affirmative action on the high education sector aiming to expand the black population access as an answer to social gaps. The University of Brasília has gain importance in this scene due to its participation in discussing this kind of public policy and due to the visibility of affirmative action's with the implementation of the quota system for undergraduate education in 2004, breaking ground nationally. The so-called "Quota Law" establishment in 2012 represented the consolidation of this public policy in the Federal sphere. On the following years, initiatives were created in public universities, suggesting a tendency to extend the quota system for stricto sensu postgraduate programs in 2015. The University of Brasilia stands as a pioneer in this type of action among higher education institutions, implementing affirmative action policies in four postgraduate studies programs. In 2014, the government encouraged this trend by establishing the goal 14.5 of the National Educational Plan, creating the challenge to increase the percentage of black teachers and doctors in Brazil. In this context, this dissertation is relevant for providing further discussions on a relatively unexplored subject, and to contribute to develop a public policy as it analyzes actions to increase the access of black people to stricto sensu postgraduate programs in the University of Brasilia from 2004 to 2015. $t$ is a qualitative and exploratory. To achieve the research objective a methodological approach was established including the definition of data collecting and analysis that better reached the specific goals. The methodological approach involved collecting data through document analysis and semistructured interviews. The analysis technics included documental and content analysis. Two dimensions and four theoretical ex-ante categories were defined witch reflected the specific goals. This structure guided the following definitions, such as the elaboration of research questions. Thereby, by the end of the analysis, four final categories were defined and they represent specific objective results. The results show that $\mathrm{UnB}$ has been silent with the lack of institutional policy to the expansion of the black population access in the postgraduate stricto sensu courses. It is noteworthy that four departments are in the cutting edge with its isolated initiatives, possible due to the regulatory autonomy they have. The results confirm the hypothesis guideline that the University of Brasília effort to institutionalize affirmative action in postgraduate programs does not occur at the same extent as both government and students groups pressure, though pressure are guiding government agendas.
\end{abstract}

Key words: Public policy, black population, affirmative action, University of Brasília, stricto sensu postgraduate programs 


\section{LISTA DE FIGURAS}

Figura 1 - Evolução da Oferta de Cursos de Mestrado Profissional no Brasil....................... 119

Figura 2 - Exemplo de Cálculo da Lei de Cotas ............................................................. 139

Figura 3 - Representação do Processo de Pesquisa .......................................................... 145

Figura 4 - Marcos para Consolidação das Ações Afirmativas .............................................. 187

Figura 5 - Público Negro x Público Branco Ingressante no Ensino Superior........................ 194

Figura 6 - Proporção de Público Negro x Público Branco por Grau no Ensino Superior ..... 195

Figura 7 - Pressão para Política Pública de Ação Afirmativa na Pós-Graduação Stricto Sensu 


\section{LISTA DE QUADROS}

Quadro 1 - Relação Entre Dimensões x Categorias Teóricas e Objetivos Específicos

Quadro 2 - Elaboração das Perguntas das Entrevistas Semiestruturadas 158

Quadro 3 - Análise Documental e Sua Contribuição 162

Quadro 4 - Panorama das Entrevistas Semiestruturadas. 164

Quadro 5 - Domínios Possíveis da Aplicação da Análise de Conteúdo 166

Quadro 6 - Sistema de Categorização (Sintético) 167

Quadro 7 - Codificação do Sistema de Categorização 168

Quadro 8 - Sistema de Categorização (Analítico) 170

Quadro 9- Modelo Analítico de Pesquisa 183

Quadro 10 - Boas Práticas de Políticas de Ação Afirmativa em Programas de Pós-Graduação Stricto Sensu 


\section{LISTA DE ABREVIATURAS}

ALERJ

Assembléia Legistaliva do Rio de Janeiro

ANDIFES Associação Nacional dos Diregentes das Instituições Federais de Ensino Superior

ANPG Associação Nacional de Pós-graduandos

CAPES Coordenação de Aperfeiçoamento de Pessoal de Nível Superior

CEAM Centro de Estudos Avançados Multidisciplinares

CEPE Conselho de Ensino, Pesquisa e Extensão

CGEE Centro de Gestão e Estudos Estratégicos

CNE Conselho Nacional de Educação

CNPq Conselho Nacional de Desenvolvimento Científico e Tecnológico

CPP Câmara de Pesquisa e Pós-graduação

FD Faculdade de Direito

IBGE Instituto Brasileiro de Geografia e Estatística

ICS Instituto de Ciências Humanas

IFES Instituições Federais de Ensino Superior

IPEA Instituto Nacional de Pesquisa Econômica Aplicada

MEC Ministério da Educação

MCTI Ministério da Ciência, Tecnologia e Inovação

MTE Ministério do Trabalho e Emprego

PNAES Programa Nacional de Assistência Estudantil

PNE Plano Nacional de Educação

PPA Plano Pluri Anual

PPG's Programas de Pós-graduação

SEPPIR Secretaria de Políticas de Promoção da Igualdade Racial

SNPG Sistema Nacional de Pós-graduação

SPM Secretaria de Políticas para Mulher

UA Unidade Acadêmica

UERJ Universidade do Rio de Janeiro

UNEB Universidade Estadual da Bahia 


\section{SUMÁRIO}

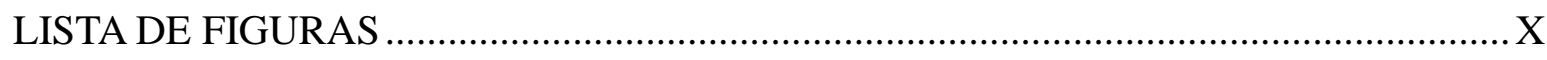

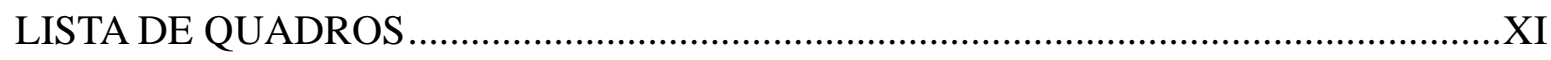

LISTA DE ABREVIATURAS ...............................................................................

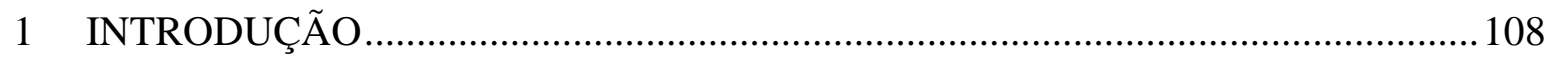

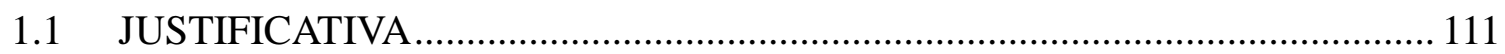

1.1.1 A meta 14, estratégia 14.5 do Plano Nacional de Educação de 2014 ................ 113

1.1.2 O Cenário dos Programas Pós-graduação stricto sensu no Brasil.................... 115

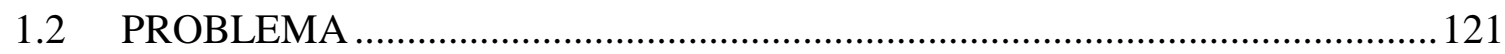

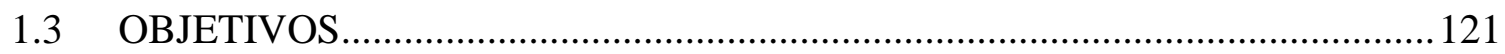

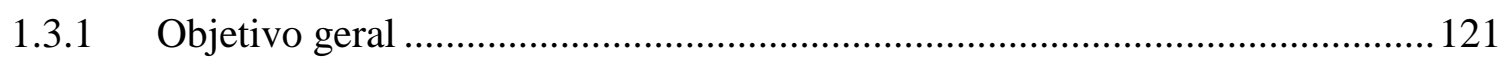

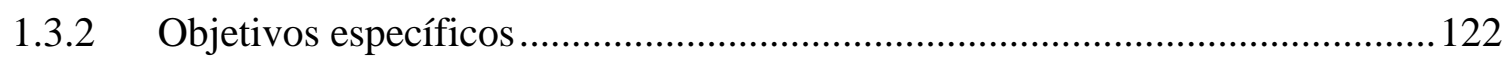

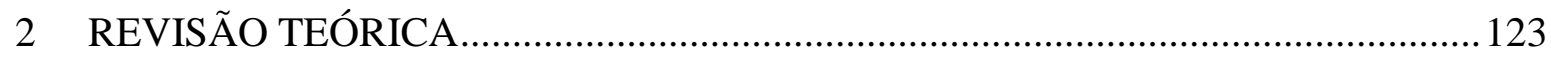

2.1 LACUNAS SOCIAIS COMO CAMPO DE ATUAÇÃO DE POLÍTICAS

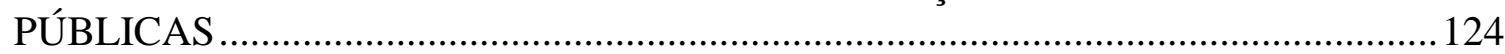

2.2 O CONCEITO DE AÇÃO AFIRMATIVA ............................................................ 126

2.3 O CONCEITO AO ACESSO NA EDUCAÇÃO SUPERIOR .................................. 129

2.4 AÇÃO AFIRMATIVA E A POLÍTICA DE PERMANÊNCIA ESTUDANTIL...... 130

2.5 O IMPACTO DA DECLARAÇÃO E PROGRAMA DE AÇÃO DE DURBAN ... 132

2.6 A SECRETARIA DE POLÍTICAS DE PROMOÇÃO DA IGUALDADE RACIAL

2.6.1 As Primeiras Experiências de Ações Afirmativas Amparadas por Leis nas Universidades Públicas

3 PERCURSO METODOLÓGICO ....................................................................... 142

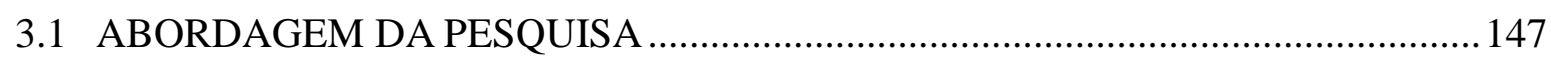

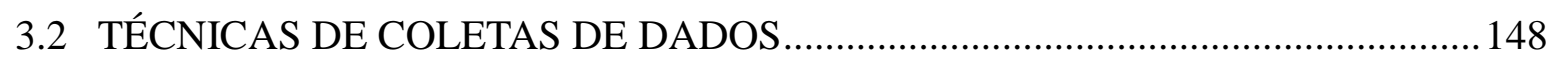

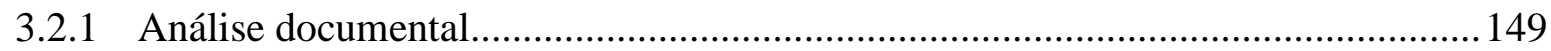

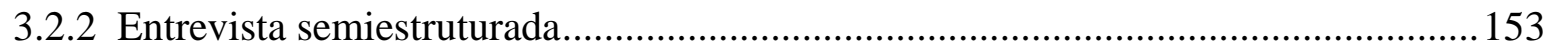

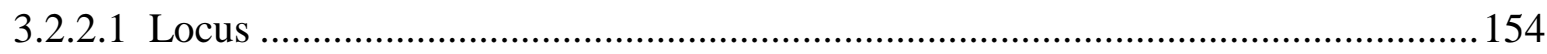

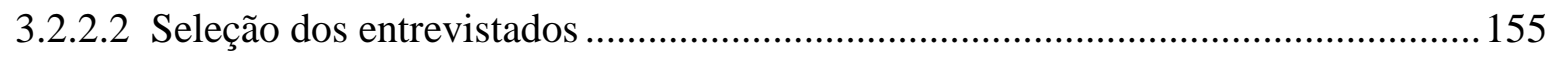

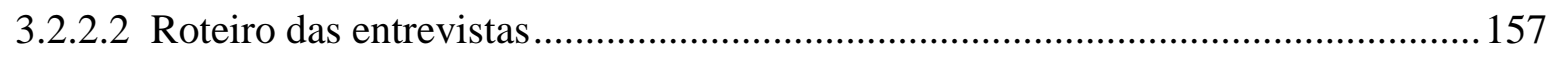

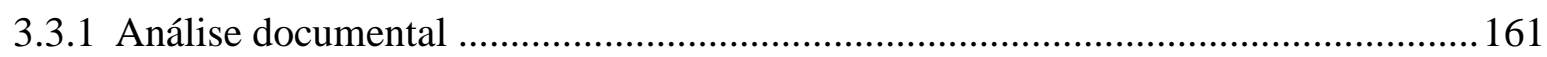

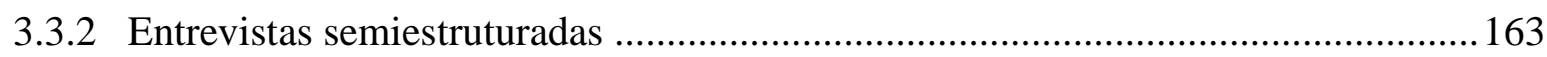




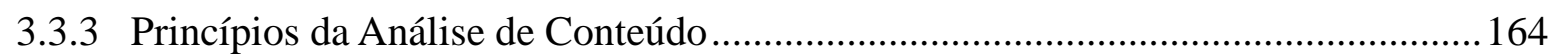

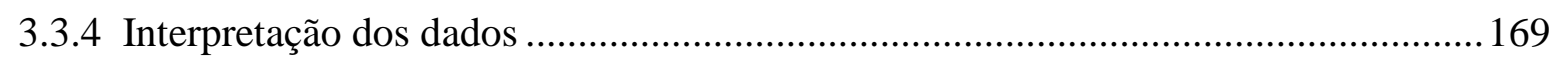

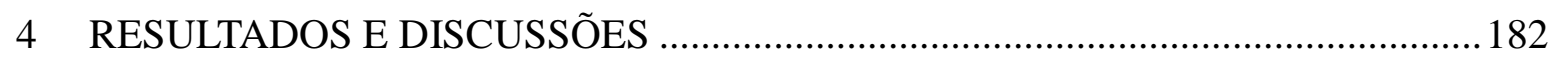

4.1 RESULTADOS GERADOS PELA ANÁLISE DOCUMENTAL..............................185

4.1.1 O Histórico das Políticas Públicas de Educação Superior que Adotam Ações Afirmativas nas Universidades Públicas do Brasil ............................................................ 185

4.1.2 A Perspectiva do Arcabouço Jurídico para Ações Afirmativas no Ensino Superior nas Universidades Públicas

4.1.3 Os Pioneiros na Implantação de Ações Afirmativas nas Universidades Públicas do Brasil.....

4.1.4 O caminho para a Implantação de Ações Afirmativas em Cursos de Pós-

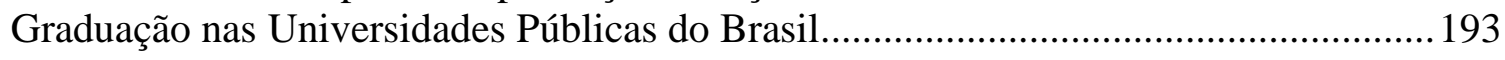

4.2 RESULTADOS GERADOS PELA ANÁLISE DE CONTEÚDO .............................. 193

4.2.1 Aprofundamento na Universidade de Brasília........................................................... 193

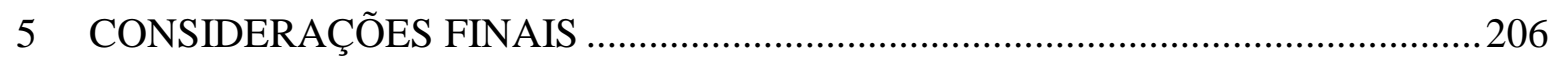

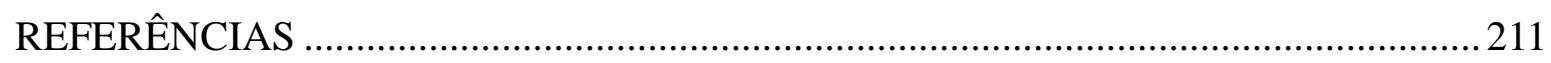

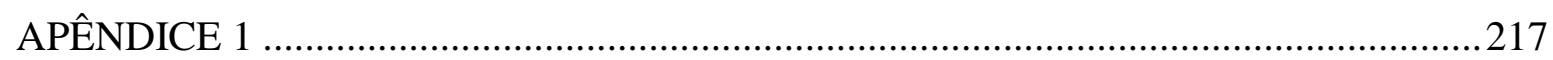

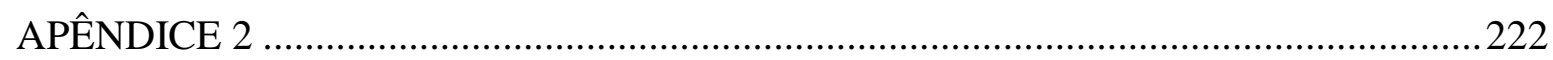

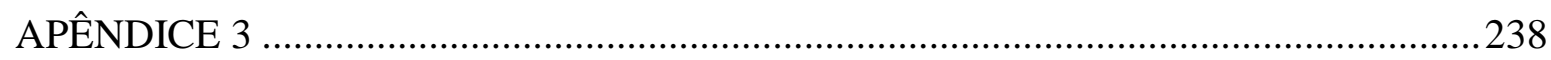

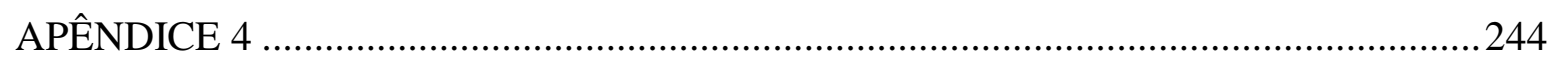

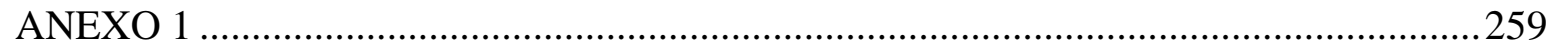

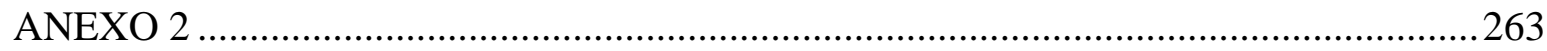




\section{INTRODUÇÃO}

Na Perspectiva da gestão pública, o setor da educação superior brasileira vem buscando implantar políticas públicas de ações afirmativas, objetivando ampliar o acesso da população negra ao Ensino Superior. O sistema de cotas para negros nos cursos de graduação é um dos exemplos dessa iniciativa, embora ainda incipiente no âmbito da pós-graduação stricto sensu. Tal modalidade foi introduzida em diversas universidades públicas, inicialmente na esfera estadual, e depois na federal, a exemplo da Universidade de Brasília, na qual passou a vigorar a partir do segundo semestre de 2004, por meio do edital de vestibular para ingresso em cursos de graduação.

Essa universidade fez um relatório contendo uma análise sobre os dez anos de experiência da UnB com o sistema de cotas. A UnB foi pioneira nas discussões (iniciadas em 1999) sobre as cotas raciais no Brasil, e que acabou tornando-se política de Estado "como evidencia o projeto de Lei em trâmite no Congresso Nacional que reserva $20 \%$ das vagas no serviço público para negros" (UNB, 2013, p. 36). Hoje, já em vigor, a Lei n. ${ }^{\circ} 12.990$, de 9 de junho de 2014, é aplicável à administração pública federal, autarquias, fundações públicas, empresas públicas e sociedades de economia mista controladas pela União. A UnB teve papel importante na visibilidade da necessidade de ações afirmativas no ensino superior.

Contins e Sant'ana (1996, p. 216) listam iniciativas anteriores registradas no país, a partir do movimento observado na esfera estadual, a exemplo do Rio de Janeiro. O projeto de lei assinado por Carlos Minc ${ }^{1}$, na Assembleia Legislativa do Estado do Rio de Janeiro, em 1993, propõe a "instituição de quota mínima (primeiro, de dez, e, depois, de vinte por cento) para setores étnicos raciais socialmente discriminados em instituições de ensino superior",

\footnotetext{
${ }^{1}$ Carlos Minc Baumfeld (Rio de Janeiro, 12 de julho de 1951) é geógrafo, professor, ambientalista, político, exguerrilheiro e economista brasileiro. É membro-fundador do Partido Verde (PV). É autor de inúmeras leis aprovadas pela Assembleia Legislativa do Rio de Janeiro, das quais muitas são voltadas para a defesa do meio ambiente, enquanto outras têm mais a ver com a cidadania. Com o pedido de demissão da ministra do Meio Ambiente, Marina Silva, em 13 de maio de 2008, foi convidado para assumir o ministério. Em 31 de março de 2010 deixou o ministério para concorrer novamente ao cargo de deputado estadual. Em abril de 2014, retomou seu mandato na ALERJ, onde ocupou a presidência da Comissão de Combate às Discriminações e Preconceitos de Raça, Cor, Etnia, Religião e Procedência Nacional. Atualmente, é o Presidente da Comissão Especial para Acompanhar o Cumprimento das Leis da ALERJ e de Combate à Impunidade e à Violência (Fonte: <https://pt.wikipedia.org/wiki/Carlos_Minc〉. Acesso em 29 de dezembro de 2015).
} 
dentre eles a população de negros e índios. "O texto relativo a essa iniciativa circulou por várias instâncias do movimento negro, gerando debates e posturas tanto favoráveis quanto desfavoráveis".

Contudo, tais ações não têm como foco o acesso dos negros à pós-graduação stricto sensu. O reflexo pode ser observado sob a perspectiva do estudo intitulado 'Mestres 2012: estudo da demografia da base técnico-científica brasileira', um esforço integrado entre o Centro de Gestão e Estudos Estratégicos (CGEE), a Coordenação de Aperfeiçoamento de Pessoal de Nível Superior (Capes/MEC), o Ministério da Ciência, Tecnologia e Inovação (MCTI), o Ministério do Trabalho e Emprego (MTE), o Conselho Nacional de Desenvolvimento Científico e Tecnológico (CNPq) e o Instituto Brasileiro de Geografia e Estatísticas (IBGE); que demonstra o espantoso número, a saber: cerca de apenas $8 \%$ da população total, em 2012, era formada por titulados negros (3\% dos mestres e $2 \%$ dos doutores).

\begin{abstract}
A população de mestres e doutores é muito mais branca do que a população como um todo. Os brancos correspondiam a $47 \%$ da população residente no Brasil no ano de 2010 , mas sua participação chegava a cerca de $80 \%$ da população de residentes cujo nível mais elevado de instrução era o mestrado e o doutorado. Em compensação, os pardos, que representavam $42 \%$ da população total, alcançavam apenas $16 \%$ da população de mestres e $12 \%$ da de doutores. E os negros, cerca de $8 \%$ da população total, representavam apenas $3 \%$ dos mestres e $2 \%$ dos doutores (CGEE, 2012, p. 22).
\end{abstract}

A falta de ações de estímulos ao acesso à população negra em programas de pósgraduação stricto sensu pode ser verificada também no relatório da Universidade de Brasília (UnB, 2013). Nesse documento constam os dados de uma pesquisa realizada com uma amostra de cotistas egressos, para os quais foram feitas uma pergunta com objetivo de conhecer a sua situação em relação à pós-graduação. No resultado, apresentado no Anexo 2, constata-se que, dos $57 \%$ dos cotistas, a maior parte não havia feito, nem estava cursando algum curso de pós-graduação; $15 \%$ fez ou estava cursando o mestrado; e, $1 \%$ fiz ou estava cursando doutorado. 
A pesquisa se deu sob a perspectiva macro da instituição ${ }^{2}$ a fim de verificar o posicionamento da gestão da universidade com relação ao tema. Esse formato se deu em função da formação da autora em Administração, que tende a adotar o olhar dos fatores organizacionais. Por isso, esta pesquisa estuda a questão da ampliação do estímulo ao acesso da população negra na pós-graduação stricto sensu, como um aprofundamento do caso na instituição Universidade de Brasília.

Esta Dissertação trata-se de uma pesquisa qualitativa e exploratória. Grawitz (1975, p. 363) afirma que uma pesquisa exploratória de uma comunidade mais ou menos ampla será orientada para uma descrição, tratando de uma forma geral a totalidade do sistema social de um determinado grupo: instituições, ritos, entre outros.

Foi adotado como meio de compreensão do objeto de pesquisa o modelo de "Processo de pesquisa em administração", de Hair et al (2005, p. 76), compreendido em três fases: 1) Formulação, "a definição da substância e do processo de pesquisa" - representada pela parte introdutória, inclusive, definição dos objetivos até a revisão da literatura; 2) Execução, reunião de informações a serem verificadas, codificadas e armazenadas para análise - parte do percurso metodológico, até a definição das técnicas de coletas de dados; e, 3) Análise dos dados obtidos, que fornecem respostas às questões da pesquisa - parte final desde as técnicas de análise de dados.

A primeira fase foi concebida por meio de revisão da literatura que ancorou todo o trabalho. $\mathrm{Na}$ fase de execução, foram utilizadas as técnicas de coletas de dados análise documental e entrevistas semiestruturas. Para analisar os dados obtidos em campo, foram utilizadas as técnicas análise documentar e análise de conteúdo. Essas fases geraram resultados que possibilitaram realizar a discussão e a conclusão da Dissertação, representando a terceira fase da pesquisa.

\footnotetext{
${ }^{2}$ Teoria institucional: de maneira sintética, podemos afirmar que, nos estudos organizacionais, essa abordagem dá especial atenção a aspectos institucionais do ambiente, conjugado com sua dimensão técnica. Nesse sentido, valoriza as implicações sobre a ação e o comportamento organizacional, mas investiga também temas ligados à compreensão de processos de produção, manutenção e transformação de normas sociais; além do relacionamento entre normas formais e informais, da mudança institucional e da influência de crenças culturais na ascensão de estruturas institucionais e formas organizacionais, entre outras questões (GUARIDO FILHO et al, 2005, 2009, p. 2 e 3$)$.
} 
A última década foi escolhida como recorte temporal, por ser considerada o período no qual ocorreu uma consolidação das ações afirmativas na graduação, observados os movimentos para a construção de uma política pública de ação afirmativa institucional para acesso da população negra também em cursos de Pós-graduação stricto sensu.

\subsection{JUSTIFICATIVA}

A questão do acesso da população negra ao ensino superior é amplamente discutida na sociedade, e, por isso, existe uma política de governo com o objetivo de dar uma resposta a essa demanda social, a Lei das cotas N $.^{\circ} 12.711 / 2012$, que abrange as instituições federais de ensino superior.

Quando se trata de pós-graduação stricto sensu, não se observam muitas discussões. Pode-se considerar como premissa o fato de que o assunto na graduação alcançou um grau de maturidade, o que justifica, por essa perspectiva, a ampliação do foco para a pósgraduação stricto sensu.

Na esfera federal, a Universidade de Brasília inova ao implantar, em 2014, Programas de Pós-graduação (PPG's) stricto sensu, com reserva de vagas para a população negra, por meio de iniciativas isoladas de três unidades acadêmicas, abrangendo quatro cursos, mesmo sem haver uma política pública de ação afirmativa implantada institucionalmente, como foi o caso da graduação. Na esfera estadual, essa iniciativa ocorre desde 2002, a exemplo da Universidade Estadual da Bahia (UNEB).

Observa-se, desde 2012, após a determinação da Lei das Cotas, um momento de aumento da pressão por diversos setores da sociedade, para a institucionalização de uma política publica de ação afirmativa para ampliação ao acesso da população negra aos cursos de pós-graduação stricto sensu, tais como: o lançamento pelo governo, em 2014, da meta 14 no Plano Nacional de Educação, discutida na sequência, sinalizando um início de diretriz para esse tema; além da UNEB, que institucionalizou, a reseva de vagas para negros na pós- 
graduação junto com a graduação, resultando em outras iniciativas que começam a surgir no âmbito dos próprios cursos, como, por exemplo, na UFRJ e na própria UnB, que ampliaram o sistema de cotas nos cursos de Antropologia Social em 2014 e 2015, respectivamente; o movimento dos estudantes pressionando melhorias ao acesso e permanência de negros e desprivilegiados economicamente, como ocorreu, recentemente com a iniciativa da Associação de Pós-graduandos da UnB (APG), que priorizou a discussão sobre a necessidade de haver ações afirmativas no I Fórum de Representantes Discentes dos Programas de PósGraduação da $\mathrm{UnB}^{3}$, criando um documento onde expressa a demanda por institucionalização de cotas na pós-graduação.

Segundo Minayo (2001, p. 41) a justificativa “(:) Trata-se da relevância, do por que tal pesquisa deve ser realizada. Quais motivos a justificam? Que contribuições para a compreensão, intervenção ou solução do problema de tal pesquisa?”. Desta forma, este estudo é relevante uma vez que promove a ampliação dessas reflexões, trazendo visibilidade às ações, ainda incipientes, no cenário de institucionalização de uma política pública de ação afirmativa que amplie o acesso da população negra nos PPG's stricto sensu. A meta 14 do PNE estipulada pelo governo via Ministério da Educação (MEC) pode ser vista como iniciativa que representa uma oportunidade para discutir o tema. As iniciativas crescentes dos PPGs, com autonomia para isso, reforça a relevância desse debate. Esta pesquisa agrega com contribuições para compreensão dos movimentos que estão ocorrendo e, principalmente, como a Universidade de Brasília está tratando o tema sob a perspectiva de sua atuação enquanto gestão.

\footnotetext{
${ }^{3}$ O I Fórum de Representantes Discentes da Pós-graduação da UnB foi organizado pela Associação de Pósgraduandos (APG), Ieda Delgado da Universidade de Brasília. Foi realizado no dia 29 de junho de 2015, no Salão de Atos da UnB. O objetivo do fórum foi reunir representantes para discutir problemas que os estudantes de pós-graduação enfrentam na grande maioria dos programas e institutos, na UnB. O fórum foi realizado em parceria com o Decanato de Pesquisa e Pós-graduação, e foi discutido em eixos temáticos, além de espaços deliberativos. Os eixos temáticos foram relativos às condições de pesquisa, assistência estudantil, sendo que ações afirmativas foram votados. Da discussão saíram documentos que são as "opiniões dos representantes discentes acerca da comunidade acadêmica da universidade, que abriga cerca de 8 mil pós-graduandos stricto sensu, mais os lato sensu", afirma Gabriel Nascimento, Vice-Presidente Regional Centro-Oeste da ANPG e membro da APG Ieda Delgado, da UnB. (Fonte: 〈http://www.anpg.org.br/?p=8635>, Acesso em 20 de dezembro).
} 


\subsubsection{A meta 14, estratégia 14.5 do Plano Nacional de Educação de 2014}

O Governo Federal lançou o Plano Nacional de Educação (PNE), sob a tutela do Ministério da Educação (MEC), em forma de lei, n. ${ }^{\circ}$ 13.005, de 25 de junho de 2014, com proposta de um planejamento de longo prazo, com vigência de dez anos, em cumprimento à Carta Magna, Art. 214. A alteração de plano plurianual para decenal foi feita em 2009, pela

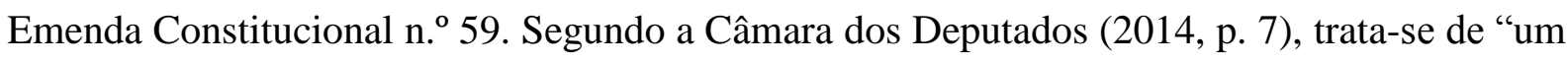
instrumento de planejamento do nosso Estado democrático de direito que orienta a execução, o aprimoramento de políticas públicas do setor". A ideia foi: "aperfeiçoar seu objetivo" de articular o "sistema nacional de educação em regime de colaboração e definir diretrizes, objetivos, metas e estratégias de implementação para assegurar a manutenção e o desenvolvimento do ensino, em seus diversos níveis, etapas e modalidades, por meio de ações integradas das diferentes esferas federativas" (BRASIL, 2014, p. 9).

$\mathrm{O}$ instrumento segue diretrizes que modificam indicadores importantes como a erradicação do analfabetismo e a melhoria da qualidade da educação, de acordo com a documento de referencia do PNE (Brasil, 2014, p.9). Para alcançar seus objetivos, o governo estipulou as metas para os diversos segmentos, a saber: Meta 1 - Educação Infantil; Meta 2 Ensino Fundamental; Meta 3 - Ensino Médio; Meta 4 - Inclusão; Meta 5 - Alfabetização Infantil; Meta 6 - Educação Integral; Meta 7 - Qualidade da Educação Básica/IDEB; Meta 8 - Elevação da Escolaridade/Diversidade; Meta 9 - Alfabetização de Jovens e Adultos; Meta 10 - EJA Integrada; Meta 11 - Educação Profissional; Meta 12 - Educação Superior; Meta 13 - Qualidade da Educação Superior; Meta 14 - Pós-Graduação; Meta 15 - Profissionais da Educação; Meta 16 - Formação; Meta 17 - Valorização dos Profissionais do Magistério; Meta 18 - Planos de Carreira; Meta 19 - Gestão Democrática; Meta 20 - Financiamento da Educação.

Constata-se a existência de uma meta incluída no Plano Nacional de Educação em 2014, a qual torna o assunto compulsório, além de revelar sua importância para a sociedade, colocando um peso ainda maior na contribuição deste estudo.

Em junho de 2014, foi sancionada a Lei n. ${ }^{\circ}$ 13.005, que aprova o Plano Nacional de Educação (PNE), com vigência de 10 (dez) anos, a partir da publicação da lei, com a finalidade de regulamentar uma determinação estabelecida pela Constituição Federal de 1988, 
em seu artigo 214. No inciso III do PNE está definido a diretriz de "superação das desigualdades educacionais, com ênfase na promoção da cidadania e na erradicação de todas as formas de discriminação (Lei 13.005 de 25 de junho de 2014, p. 1)":

\begin{abstract}
Meta 14: elevar gradualmente o número de matrículas na pós-graduação stricto sensu, de modo a atingir a titulação anual de 60.000 (sessenta mil) mestres e 25.000 (vinte e cinco mil) doutores. [...] 14.5) implementar ações para reduzir as desigualdades étnico-raciais e regionais e para favorecer o acesso das populações do campo e das comunidades indígenas e quilombolas a programas de mestrado e doutorado (Lei 13.005 de 25 de junho de 2014, p. 25)
\end{abstract}

Essa meta pode ser considerada uma medida relevante à implantação de ações afirmativas ao acesso da população negra a Programas de Pós-graduação stricto sensu, já que, de acordo com o censo do Instituto Brasileiro de Geografia e Estatística (IBGE), 79,18\% dos mestres no país são brancos. Como foi verificado, a experiência e a legislação brasileiras privilegiam a implantação dessas políticas no âmbito da graduação, cuja exceção é a Universidade Estadual da Bahia (UNEB), que desde 2002 englobou a pós-graduação em seu sistema de cotas.

Seguindo o viés social do governo, a estratégia 14.5 objetiva diminuir as desigualdades sociais no âmbito dos cursos de Pós-graduação stricto sensu com o estímulo ao acesso de negros e outros grupos nesses programas. A estratégia do governo desafia às instituições de ensino superior a discutirem, estudarem e implantarem ações afirmativas para acessos de negros também aos cursos de mestrado e doutorado.

No entendimento da Câmara dos Deputados (2014, p. 7), o Plano Nacional de Educação é uma

\footnotetext{
"lei viva, a ser lida, revisitada e, principalmente, observada. O seu cumprimento é objeto de monitoramento contínuo e de avaliações periódicas realizadas pelo Ministério da Educação (MEC), pelas comissões de educação da Câmara e do Senado, pelo Conselho Nacional de Educação (CNE) e pelo Fórum Nacional de Educação" (BRASIL, 2014).
}

Posto isso, Carvalho (2006, p. 101), considerando-se a existência de um conhecimento acumulado decorrentes de pesquisas científicas, dados estatísticos e opiniões a respeito das questões de desigualdades étnico-raciais e das ações afirmativas no ensino superior, explica que 
o ideário das cotas, que apenas começam na graduação, aponta para questionamentos teóricos e metodológicos muito mais densos e amplos do que possam parecer à primeira vista. A ideologia da mestiçagem, por exemplo, tão difundida nas ciências sociais brasileiras, é uma teoria cara aos acadêmicos brancos; já os acadêmicos negros não se identificam com ela e a maioria deles vê o discurso da mestiçagem como parte de uma ideologia racista que visa a desautorizar e a desarmar a afirmação de uma negritude. E sem negritude não há demanda por reparação dos danos causados aos atuais descendentes negros após séculos de escravidão.

Portanto, reconhecendo o conhecimento acumulado, fruto dessas discussões, esta Dissertação ganha relevância, uma vez que dá visibilidade às principais políticas de inclusão de estudantes negros na pós-graduação stricto sensu na educação superior, aprofundando os estudos na Universidade de Brasília, no período que compreende 2004 a 2015, contribuindo para o avanço dessa política pública.

\subsubsection{O Cenário dos Programas Pós-graduação stricto sensu no Brasil}

De acordo com Cury (2005, p.7) a pós-graduação consolidou-se no final dos anos 1960, e sua institucionalização teve como marco histórico o ano de 1930, na era Vargas, pelo decreto n. ${ }^{\circ}$ 19.851, de abril de 1931, o qual, em seu Art. $1^{\circ}$, impunha "investigação científica em quaisquer domínios dos conhecimentos humanos, como a finalidade do ensino universitário”. O autor destaca, ainda, o papel importante da Universidade de Brasília (UnB) na criação específica da pós-graduação, considerando "um dos seus momentos mais significativos", o que ocorreu na criação da fundação da Universidade de Brasília (UnB), estabelecida pela lei n. ${ }^{o}$ 3.998, de 15 de dezembro de 1961.4. Nessa universidade, a pósgraduação tornou-se uma atividade institucional.

O parecer CES/CFE 977, de 1965, contribuiu com a definição de pós-graduação stricto sensu, cuja base conceitual utiliza-se até hoje. Esse documento teve dois objetivos: definir os cursos de pós-graduação, uma vez reconhecida a imprecisão sobre a natureza desses cursos; e, implantar e desenvolver o regime de cursos de pós-graduação no ensino superior (BRASIL, 2005, p. 162).. O conceito estabelecido foi o ciclo de cursos regulares em segmento à graduação, sistematicamente organizados, visando desenvolver e aprofundar a formação 
adquirida no âmbito da graduação e conduzindo à obtenção de grau acadêmico (BRASIL, 2005, p. 166).

Esse parecer foi fundamentado a partir do estabelecimento de características consideradas fundamentais a estarem presentes nos cursos de pós-graduação stricto sensu, a saber, ao stricto sensu

\begin{abstract}
é de natureza acadêmica e de pesquisa e mesmo atuando em setores profissionais tem objetivo essencialmente científico, enquanto a especialização, via de regra, tem sentido eminentemente prático-profissional; confere grau acadêmico e a especialização concede certificado; finalmente a pós-graduação possui uma sistemática formando estrato essencial e superior na hierarquia dos cursos que constituem o complexo universitário (BRASIL, 2005, p. 166).
\end{abstract}

A pós-graduação stricto sensu é dividida em dois níveis, definidos no referido parecer: o primeiro é o mestrado, que pode ser encarado como etapa preliminar na obtenção do grau de doutor ou como grau terminal; e o segundo é o doutorado, que tem por finalidade proporcionar formação científica ou cultural ampla e aprofundada, desenvolvendo a capacidade de pesquisa e poder criados nos diferentes ramos do saber. Segundo o parecer, é possível fazer o doutorado sem passar pelo mestrado. Uma curiosidade é que o documento foi relatado por Newton Sucupira, que inspirou o nome do sistema de base de dados de avaliação dos Programas de pós-graduação stricto sensu.

O governo atua por intermédio da Coordenação de Aperfeiçoamento de Pessoal de Nível Superior (CAPES), órgão responsável pelo funcionamento dos programas de pósgraduação stricto sensu (PPG,s). A Capes é uma fundação do Ministério da Educação (MEC), cuja missão é desempenhar "papel fundamental na expansão e consolidação da pós-graduação stricto sensu (mestrado e doutorado) em todos os estados da Federação" (CAPES, 2014).

Com base na chamada Lei de Diretrizes Bases da Educação, n. ${ }^{\circ}$ 9.394, de 20 de dezembro de 1996, a pós-graduação stricto sensu abrange os programas de mestrado e doutorado, ofertados a candidatos com formação comprovada em cursos superiores de graduação e que atendam às exigências das instituições de ensino e ao edital de seleção. Portanto, os Programas de Pós-graduação (PPG's) concretizam a pós-graduação stricto sensu nas unidades acadêmicas das universidades, no contexto do ensino superior público brasileiro. 
O governo atua, por intermédio do órgão responsável, no funcionamento dos PPG's e na Coordenação de Aperfeiçoamento de Pessoal de Nível Superior (Capes). Essa é uma fundação do Ministério da Educação (MEC), cuja missão é desempenhar "papel fundamental na expansão e consolidação da pós-graduação stricto sensu (mestrado e doutorado) em todos os estados da Federação" (CAPES, 2014).

Os PPG’s são sistematicamente avaliados segundo o modelo implantado a partir de 1998, chamado de Sistema Nacional de Pós-Graduação (SNPG). A CAPES entende que a avaliação é atividade essencial para assegurar e manter a qualidade dos cursos de mestrado e doutorado no país. A área na Capes responsável pela orientação dos trabalhos é a Diretoria de Avaliação, que conta com a participação da comunidade acadêmico-científica, por meio de consultores ad hoc para realizar as avaliações in loco. Os resultados da avaliação servem de base para a formulação de políticas para a área de pós-graduação, bem como para o dimensionamento das ações de fomento (bolsas de estudo, auxílios, etc).

Para garantir a qualidade dos cursos de mestrado e doutorado, critérios operacionais e normas são necessários para dirigir e controlar sua implantação e desenvolvimento. A autorização, reconhecimento e renovação de reconhecimento dos cursos de mestrado acadêmico e doutorado são obtidos a partir dos resultados da avaliação e do acompanhamento conduzidos pela CAPES, de acordo com as exigências previstas na legislação, a Resolução CNE/CES n. ${ }^{\circ}$ 1/2001, alterada pela Resolução CNE/CES n. ${ }^{\circ}$ 24/2002.

A Capes, por intermédio do Conselho Nacional de Educação (CNE), recomenda os cursos de Pós-graduação stricto sensu - mestrado profissional/acadêmico e doutorado com nota igual ou superior a '3', para que os cursos novos sejam reconhecidos e os em funcionamento sejam renovados. Apenas esses cursos têm autorização do CNE/MEC para expedirem diplomas com validade nacional.

Críticas têm sido feitas ao Sistema de Avaliação da Capes, com a discussão girando em torno da dicotomia 'quantitativo versus qualitativo'. Essas

\footnotetext{
"se desdobram em diversas variáveis, como subjetivo ou objetivo, concentrado na formação de centros de excelência ou na perspectiva inclusiva, centrado no professor ou no aluno, estruturalista ou pós-estruturalista, dentre outros, o que tem impedido a possibilidade/necessidade de formatar novos consensos sobre o assunto" (TREVISAN et al, 2013, p. 375)
} 
Trevisan et al (op.cit., p. 374) afirma

"que existem duas grandes linhas de pensamento sobre esse assunto: uma, que caminha em favor da manutenção da avaliação que vem sendo utilizada e, outra, que a rejeita, por considerá-la excessivamente concentrada na avaliação do aspecto somente quantitativo da produção dos programas. É um assunto que produz muita discussão e controvérsias".

A própria CAPES (2010, p. 34), dmite a necessidade de avançar em seu processo avaliativo, o que fica claro no Plano Nacional para a Pós-graduação 2011-2020, no título 'Nota Sobre a Transição Necessária da Pós-Graduação Brasileira', na reflexão abaixo.

\begin{abstract}
A pós-graduação brasileira, ao dar prioridade ao desempenho acadêmico, através de um conjunto de instrumento de regulação legal, incentivos e mecanismos de avaliação, ao lado de muitos resultados positivos, acabou criando um sistema altamente subsidiado cuja principal função, na prática, é se auto-alimentar, e que, com exceções de sempre, nem conseguem produzir uma ciência de padrão internacional, nem consegue gerar tecnologia avançada para o mercado de trabalho não acadêmico.

O sistema atual de avaliação e apoio à pós-graduação no Brasil, que existe desde os anos 70, cumpriu funções importantes, mas agora precisa ser alterado no sentido de reduzir a centralização e estimular a autonomia e a diversificação dos diversos programas e objetivos que coexistem sob esta denominação geral.
\end{abstract}

Os cursos de mestrado profissional foram criados em 1999, tendo como público alvo os interessados em obter alto nível de qualificação profissional, sendo essa a principal diferença em relação ao mestrado acadêmico. Tem como ethos a busca pela alta qualidade profissional de quem opta por esse tipo de curso, segundo a CAPES/MEC (2014).

A quantidade de programas de pós-graduação profissional stricto sensu ofertados no Brasil vem aumentando consideravelmente, sugerindo ser uma tendência para consolidação da modalidade. No ano de sua criação, foram ofertados 04 cursos no país, sendo que esse número aumentou para 62 em 2003, e, em 2007, subiu para 184, enquanto que, em 2011, aumentou para 522, chegando a 574 até Julho de 2015 (PORTAL BRASIL, 2014). 
Figura 1 - Evolução da Oferta de Cursos de Mestrado Profissional no Brasil

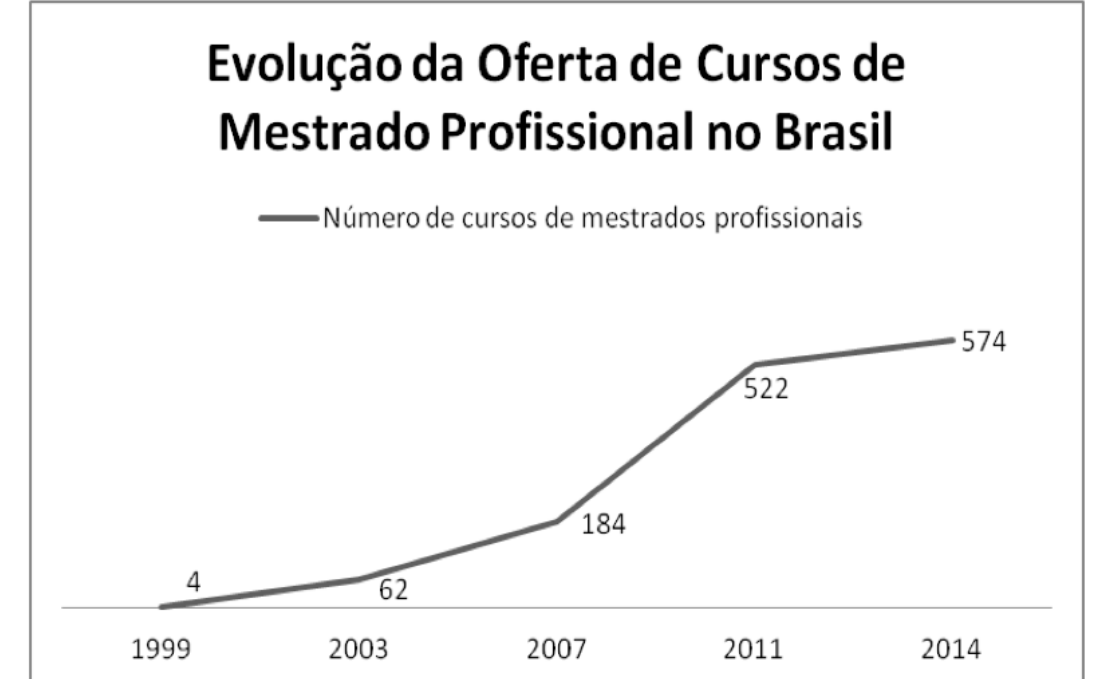

Fonte: Elaborado com base em dados de cursos recomentados no sítio da Capes

Existiam, em 2014, onze cursos de mestrado profissional autorizados pela CAPES/MEC na Universidade de Brasília (UnB), que representavam 2\% em relação a todas as Instituições de Ensino Superior (IES) do país, correspondendo a $65 \%$ dentre as universidades. Com relação às IES, e no âmbito da região centro-oeste, esses cursos correspondiam a $29 \%$ e, ainda, comparando com o Distrito Federal (DF) representavam 65\% dos mestrados profissionais existentes. Posto isso, pode-se inferir que os cursos de mestrado profissional da UnB representavam importante papel com um número significativo no cenário nacional, regional e local até 2014. (CAPES/MEC, 2014). Esta é a situação atual dos programas de pós-graduação stricto sensu, bem como da avaliação feita periodicamente pela CAPES.

No que tange as ações afirmativas, muito tem se estudado a respeito das políticas públicas de incentivo da população negra à pós-graduação stricto sensu, e, com isso, diversas ações afirmativas têm sido adotadas quando se fala em graduação, embora pouco tem se pesquisado com relação ao tema. A falta de registro da raça dificulta identificar o número de pessoas negras matriculadas, dificultando também a realização de uma análise mais acurada, e se há lacuna que distancia esse público do ingresso nesses programas.

O relatório feito pela própria universidade sobre sua experiência afirmativa de 10 anos nos cursos de graduação contribui para sinalizar que há demanda por parte desse público. Realizou-se uma entrevista com um grupo de cotistas de graduação egressos em que, dentre as 
perguntas, havia uma direcionada à pós-graduação, a saber: "Fez ou está fazendo curso de pós-graduação?”. A pesquisa realizou-se com a partir dos seguintes procedimentos:

Procedimentos da Pesquisa: A pesquisa ocorreu no período entre 20 de maio de 2013 e 09 de junho de 2013. Nesse intervalo, de tempo foi disponibilizado um questionário online para ser respondido pelos cotistas. O link desse questionário foi enviado para um total de 1.504 cotistas no dia 20/05 e seis novos envios foram feitos no período para aqueles que ainda não haviam respondido a pesquisa. Foram enviadas também aos cotistas mensagens de texto, via SMS , no início da pesquisa e uma semana antes do seu encerramento. Além disso, foi feito, ainda, contato telefônico alertando sobre a pesquisa e sua importância. Responderam ao questionário 395 cotistas, uma amostra de $26 \%$ do total de contatados (UNB, 2013).

Um gráfico com esta experiência pode ser verificado no Anexo 2: Cotistas Egressos da UnB e Suas Situações em Relação à Pós-graduação. Ficou demonstrado que "a maior parte dos cotistas (57\%) declarou não ter feito ou estar fazendo algum curso de pósgraduação" (UnB, 2013, p. 34). Isso significa que, da amostra de 395 respondentes, 226 não fizeram e nem estão fazendo pós-graduação. Enquanto que o o número dos que fizeram ou estão fazendo é de 63 (16\%), sendo, desses, 60 cursam ou cursaram mestrado (15\%), 3 doutorado (1\%). A pesquisa também apontou que 104 dos entrevistados fizeram ou fazem especialização (26\%), e 2 aperfeiçoamento (1\%).

No âmbito nacional, verifica-se uma incipiente aplicação do sistema de cotas da graduação para a pós-graduação, tendo como pioneiro o programa de Antropologia Social do Museu Nacional da UFRJ, que teve sua proposta aprovada em 2013 e implantada a partir em 2014.

A Universidade de Brasília segue essa tendência, com a implantação de reserva de vagas em quatro de seus Programas de Pós-gradação stricto sensu acadêmicos. Os primeiros cursos a aprovarem uma ação afirmativa no PPG's foram a Antropologia, em2013; a Sociologia, em2014; ambos do Instituto de Ciências Sociais (ICS); e o curso Direitos Humanos e Cidadania, em 2014, ligado ao Centro de Estudos Avançados Multidisciplinares (CEAM), todos os três implantados em 2015. A Faculdade de Direito (FD) aprovou, no ano seguinte, em 2015, com implantação de reserva de vagas no PPG em Direito marcada para o ano de 2016. 
Esse panorama demonstra a existência de demandas de diversas frentes, convergindo para o caminho de institucionalização de políticas públicas de ação afirmativa para aumentar o acesso da população negra aos PPG's stricto sensu. A população, por meio dos movimentos negros, as unidades acadêmicas, com iniciativas isoladas dentro das universidades, e o governo com a meta 14.5 são exemplos de forças para a concretização de uma demanda embrionária na pós-graduação, após a maturidade na graduação.

\subsection{PROBLEMA}

Segundo Sampieri et al (2006) o problema de pesquisa serve para aperfeiçoar e estruturar a ideia de uma pesquisa, imprimindo maior formalismo. Para Hair et al (2005), ao ser definido o problema, um plano de ação deve ser elaborado para investigar e fazer recomendações a fim de solucioná-lo.

Esta pesquisa parte da questão do problema das ações afirmativas e da população negra em programas de pós-graduação stricto sensu, com aprofundamento na Universidade de Brasília, objetivando responder a seguinte questão: a ampliação ao acesso de alunos negros aos cursos de Pós-graduação stricto sensu da Universidade de Brasília tem atendido às demandas das pressões sociais? Para isso, parte-se da suposição: a UnB pouco tem ser esforçado institucionalmente para atender às demandas por uma política pública de ação afirmativa que estimule a ampliação ao acesso da população negra nos cursos de pósgraduação stricto sensu.

\subsection{OBJETIVOS}

\subsubsection{Objetivo geral}

Para Grawitz (1975), a função da definição do objetivo é determinar o que se quer descobrir ou medir, e, também, definir as fronteiras da investigação. Para tanto, na presente Dissertação o objetivo geral foi definido da seguinte forma: analisar as ações de ampliação ao 
acesso da população negra a programas de pós-graduação stricto sensu da Universidade de Brasília entre 2004 a 2015.

\subsubsection{Objetivos específicos}

Para que o objetivo geral fosse alcançado, estabeleceram-se algumas etapas a serem seguidas, os objetivos específicos, a saber:

1) descrever o histórico das políticas públicas de educação superior que adotam ações afirmativas praticadas nas universidades públicas do Brasil;

2) descrever/caracterizar as boas práticas das políticas de ações afirmativas em programas de pós-graduação stricto sensu;

3) descrever as ações afirmativas adotadas na Universidade de Brasília para acesso de negros em cursos de graduação e pós-graduação stricto sensu no período de 2004 a 2015;

4) identificar as dificuldades ao acesso da população negra aos Programas de Pósgraduação stricto sensu ofertados pela Universidade de Brasília sob a perspectiva da instituição sob a perspectiva da instituição. 


\section{REVISÃO TEÓRICA}

Grawitz (1975) afirma que ao se definir o objetivo, é prudente conhecer a bibliografia, tanto sobre o mesmo problema a ser tratado quanto acerca de problemas diferentes, mas estudados no mesmo local e que podem trazer dados semelhantes. Tais conhecimentos fazem parte das etapas preliminares de uma pesquisa e permite contribuir para concepção de um plano de investigação.

Os pesquisadores, por meio da teoria - definida como 'um conjunto de afirmações sistematicamente relacionadas'-, desenvolvem novas teorias fundamentadas em pesquisas realizadas com fenômenos semelhantes. De forma análoga, pesquisas em Administração fundamentam-se no histórico de instituições para desenvolver seus temas. (HAIR et al, 2005). Sampieri et al (2006) consideram importante conhecer o que já foi pesquisado, uma vez que o conhecimento acumulado contribui para o estudo atual e aponta para o futuro. Para Alyrio (2009, p. 82), a pesquisa bibliográfica, assim a chama, consiste em investigar em material teórico como livros, artigos, publicações avulsas, boletins, jornais, revistas, monografias, dissertações, teses, etc.; para, assim, "proporcionar a avaliação do assunto sob um enfoque novo ou com uma abordagem diferenciada, levando a novas conclusões".

A revisão da literatura, por meio do levantamento bibliográfico, pode ser compreendida como a parte inicial de um trabalho científico. É importante perceber que, se feita de forma completa, agrega em melhor compreensão de uma questão (Hair et al, 2005).

Para Sampieri et al (2005, p. 54), o levantamento bibliográfico, obtido na revisão da literatura, possibilita "identificar, obter e consultar" a produção bibliográfica acerca do assunto estudado, com o intuito de "extrair e recompilar" informações significativas para a pesquisa. Porém, o autor destaca a necessidade de correta seleção, em meio a publicações diversas observadas na atualidade, as quais abordam o "tema com enfoque similar" ao que se está estudando.

Neste capítulo objetiva-se a investigação do conhecimento acumulado, por meio do estudo de diversas fontes e formas, tais como, livros, artigos, documentos entre outros. 
Possibilitou-se, pela contextualização teórica, por assuntos mais amplos, por conceitos e tópicos mais estritos, a melhor compreensão das políticas públicas de incentivo à ampliação ao acesso da população negra à educação superior brasileiro.

\subsection{LACUNAS SOCIAIS COMO CAMPO DE ATUAÇÃO DE POLÍTICAS PÚBLICAS}

De acordo com Rua (1998, p. 4), as sociedades têm como principal característica a diferenciação, o que significa que seus membros possuem atributos, ideias, valores diferenciados e desempenham papéis diferentes. Para a autora, uma forma de conciliar os conflitos resultantes dessas diferenças são as políticas públicas, as quais compreendem "um conjunto de procedimentos destinados à resolução pacífica de conflitos em torno da alocação de bens e recursos públicos".

A sociedade brasileira foi formada por diferentes povos: indígenas, africanos, europeus, asiáticos, entre outros. Suas desigualdades têm origem na colonização portuguesa que, juntamente com outros povos de origem europeia, usufruíram de vantagens com relação aos demais povos. Essa ausência de igualdade de benefícios resultou nas "grandes desigualdades pautadas por diferenças de pertencimento de classe social, de grupo racial e de sexo/gênero" (SANTOS et al, 2008, p. 914). O cenário resultante demonstra que "ricos e pobres, mulheres e homens, negros, indígenas, brancos, amarelos, entre outros, têm possibilidades e maneiras muito distintas e desiguais para a obtenção de bônus e de pagamento dos ônus sociais" (SANTOS et al, op.cit, p. 914).

As desigualdades étnico-raciais geram uma demanda social recorrente, uma vez que "expressam problemas não resolvidos ou mal resolvidos, e que estão sempre voltando a aparecer no debate político e na agenda governamental” (RUA, 1998, p. 3). Porém, de acordo com a Secretaria de Políticas para Mulheres (BRASIL, 2011), da Presidência da República, historicamente, a ação do Estado tem produzido e mantido essas desigualdades. Dessa maneira, planejar a política pública, a partir da perspectiva de gênero e raça, exige reconhecer, enfrentar e eliminar os mecanismos de perpetuação das desigualdades e construir alternativas, no sentido da realização plena e progressiva dos direitos humanos e das pessoas pertencentes aos segmentos raciais discriminados. Parte-se do reconhecimento de que toda política tem 
impacto sobre as relações de gênero e no enfrentamento ao racismo. Portanto, para a Secretaria de Políticas para Mulheres, elas podem e devem ser analisadas através desta perspectiva (BRASIL, 2011).

No Brasil, observa-se a adoção de políticas públicas em combate às referidas desigualdades, as quais estão sendo largamente discutidas de forma transversal e intersetorial, englobando as três esferas do governo e seus diversos setores como Saúde e Educação, para, assim, alcançar o "entendimento mais amplo e adequado das estruturas e dinâmicas sociais que se mobilizam - na produção de desigualdades de gênero, raciais, geracionais, de classe, entre outras" (SPM, 2013, p. 9). Ao mesmo tempo, insere-se "o paradigma da responsabilidade compartilhada, ou seja, cabe a todos os órgãos dos três níveis federativos", adquirindo, assim, uma visão sistêmica.

Desde a década de 2000 até agora, a administração pública brasileira vem inserindo, cada vez mais em sua agenda, assuntos sociais e tomando medidas (políticas, planos e programas), a fim de promover oportunidades iguais para pessoas vitimadas por discriminações. Tal importância pode ser verificada no orçamento público, por meio do Plano Pluri Anual 2012-2015, Anexo 1, com o próprio "PROGRAMA: 2034 - Enfrentamento ao Racismo e Promoção da Igualdade Racial”, sob responsabilidade da Secretaria de Políticas de Promoção da Igualdade Racial da Presidência da República. (MINISTÉRIO DO PLANEJAMENTO, ORÇAMENTO E GESTÃO, 2014, p. 81 e 82).

No entendimento da SPM (2011), esse posicionamento se faz necessário, pois as políticas públicas atingem mulheres e homens de forma desigual, assim como afetam de maneira diversa os grupos étnico-raciais. "Inserir as perspectivas de gênero e raça no orçamento é, portanto, reflexo da preocupação em implementar tais políticas, garantindo os recursos para sua execução" (SPM, 2011, p. 77).

Na perspectiva social, as políticas públicas de ação afirmativa visam à "superação da subordinação social vivenciada por esses grupos, uma vez que a "participação igualitária, numa sociedade democrática exige a reconfiguração das estruturas das instituições sociais, fundamentadas no reconhecimento desses padrões culturais, objetivando a paridade de participação"”' (BORGES, 2012, p. 2). 
Dados do Instituto Nacional de Pesquisa Econômica Aplicada (IPEA) informam que, "apesar da diminuição da desigualdade ao acesso de brancos e negros à universidade nos últimos anos, ainda é pequena a presença de negros e negras nas universidades brasileiras, o que corrobora a relevância da discussão sobre ações que mitiguem o problema” (IPEA, 2011, p. 150). Essa afirmação sinaliza que as ações afirmativas intensificadas no início do milênio estão dando um resultado positivo ao proporcionar maior igualdade para a entrada nas universidades. Porém, em números, ainda tem menos negros no Ensino Superior, mostrando a necessidade de continuação dessa prática.

\subsection{O CONCEITO DE AÇÃO AFIRMATIVA}

Para analisar ações afirmativas, faz-se necessário compreender o conceito que essa expressão exprime. Contins e Sant'ana (1996) trazem uma base conceitual, obtida dos anais do seminário "International Perspectives on Affirmative Action", resultado de um encontro de pesquisadores ocorrido em agosto de 1982 no Centro de Estudos e Conferências de Bellagio na Itália”. Segundo os autores, na ocasião, foi convencionado o que chamaram de “definição operacional" sobre ação afirmativa: "uma preferência especial em relação a membros de um grupo definido por raça, cor, religião língua ou sexo com o propósito de assegurar acesso a poder, prestígio e riqueza" (CONTINS \& SANT'ANA, 1996, p. 209), proposto pelo participante Jack Greenberg. A definição foi complementada por William L Teylor, outro participante do referido seminário, reforçando "que a ação afirmativa tem como função específica a promoção de oportunidades iguais para pessoas vitimadas por discriminação". Esse viés se enquadra ao presente estudo, uma vez que defende que o objetivo das ações afirmativas é "o de fazer com que os beneficiados possam vir a competir efetivamente por serviços educacionais e por posições no mercado de trabalho" (op. cit., p. 209).

Taylor apud Contins e Sant'ana (1996) faz questão de diferenciar os conceitos de ação afirmativa das definições de reparação e redistribuição:

o primeiro necessariamente inclui como beneficiados de seus programas todos os membros do grupo prejudicado. O segundo por sua vez pressupõe como critério suficiente (ou mesmo exclusivo) a carência econômica ou socioeconômica dos membros do grupo em questão independentemente dos motivos dessa carência. A ação afirmativa diferenciar-se-ia no primeiro caso porque em programas de ação 
afirmativa o pertencimento a um determinado grupo não é suficiente para que alguém seja beneficiado; outros critérios iniciais de mérito devem ser satisfeitos para que alguém seja qualificado para empregos ou posições. Já em relação à redistribuição, ela distingue-se por configurar-se em medida de justiça (implicando a finalidade de reparação) a qual constitui-se em argumento legal para o seu pleito, tal como a jurisprudência norte-americana a consagrou. (CONTINS \& SANT'ANA, 1996, p. 209)

Alguns autores se referem às ações afirmativas como medidas compensatórias, a exemplo de quando afirma que a focalização das políticas universalistas "sobre grupos específicos seria um modo de tornar possível que seja dado mais a quem mais precisa e compensar ou reparar sequelas do passado" (PEIXOTO \& BRAGA, 2012, p. 167), embora sua implementação fosse insuficiente para promover a inclusão na visão dos autores.

Os próprios Contins e Sant'ana (1996, p. 218), ora mencionados, afirmam que as ações afirmativas ajudaram os negros no Brasil, e, portanto, enquanto "ação compensatória, visa, segundo este ponto de vista, à discriminação historicamente sofrida pelos negros no Brasil". Para os autores, partindo-se da ótica de que as desigualdades étnico-raciais devem ser resolvidas dentro do Estado, e não fora dele, a "assistência compensatória deve agir primordialmente na educação que é onde ela atinge o maior número de pessoas" (op.cit., p. 217).

No contexto brasileiro, a Secretaria de Políticas de Promoção da Igualdade Racial da Presidência da República - SEPPIR ${ }^{4}$, define ações afirmativas como "políticas públicas feitas pelo governo ou pela iniciativa privada com o objetivo de corrigir desigualdades raciais presentes na sociedade, acumuladas ao longo de anos" (SEPPIR, 2014). A SEPPIR classifica três tipos, de acordo com a finalidade: 1) para reverter a representação negativa dos negros; 2) para promover igualdade de oportunidades; e 3) para combater o preconceito e o racismo.

Extrapolando a definição, para a SEPPIR, as ações afirmativas no Brasil estão alicerçadas no conceito de equidade expresso na constituição, cuja essência é tratar os iguais

\footnotetext{
4 SEPPIR - Secretaria de Políticas de Promoção da Igualdade Racial, criada pela Medida Provisória n ${ }^{\circ}$ 111, de 21 de março de 2003, convertida na Lei $n^{\circ}$ 10.678. A Secretaria de Políticas de Promoção da Igualdade Racial da Presidência da República nasce do reconhecimento das lutas históricas do Movimento Negro Brasileiro. Porém, em meio à crise econômica do ano corrente a esta pesquisa, a Presidente Dilma Rousseff (PT) decidiu criar o Ministério da Cidadania, o qual unirá as Secretarias das Mulheres, da Igualdade Racial, dos Direitos Humanos e a Secretaria Geral da Presidência. (Fonte: <http://www.seppir.gov.br/sobre-a-seppir/o-ministerio, e, http://www.brasil247.com/pt/247/brasil/198237/Minist\%C3\%A9rio-da-Cidadania-reunir\%C3\%A1-IgualdadeDireitos-Humanos-e-Mulheres.htm> Acesso em 29 de dezembro de 2015)
} 
de forma igual e os desiguais de forma desigual. Dessa forma, a Secretaria adota ações de estímulos ao público considerado sem oportunidades iguais em função de discriminação e racismo.

O MEC define ações afirmativas como sendo "o conjunto de medidas especiais voltadas a grupos discriminados e vitimados pela exclusão social ocorridos no passado ou no presente". Coloca como objetivos institucionais "eliminar as desigualdades e segregações, de forma que não se mantenham grupos elitizados e grupos marginalizados na sociedade, ou seja, busca-se uma composição diversificada onde não haja o predomínio de raças, etnias, religiões, gênero, etc.” (BRASIL, 2014).

De acordo com estudo do IPEA, ações afirmativas são "benefícios temporários concedidos a grupos sociais discriminados com o intuito de promover a igualdade de oportunidade em diferentes dimensões da vida social, em especial, na educação e no trabalho" IPEA (2011). Porém, trata-se de um esforço necessário que deve ser complementado com outros tipos de políticas públicas, abrangendo todas as nuances envolvidas, como bem explica o estudo do IPEA, que afirma:

contudo, as ações afirmativas, por si só, não são suficientes para romper com as
desigualdades raciais existentes no país. Devido à configuração da estrutura social
brasileira, é necessário que estas políticas sejam implementadas em articulação com
políticas universais, especialmente no caso da educação. Ademais, em sociedades
permeadas pelo racismo e outras discriminações, é também necessário haver uma
articulação de políticas que visem não só à promoção da igualdade racial, mas
também ao combate ao preconceito e à discriminação - inclusive por meio de um
aparato repressivo-punitivo, conforme concordam Luciana Jaccoud e Mário
Theodoro (2005) e Flávia Piovesan (2005) (IPEA, 2011, p. 157).

Do conceito às questões que estão por trás das ações afirmativas, pode-se dizer que são elas necessárias e estão mostrando resultados na igualdade de oportunidade ao acessos no Ensino Superior no Brasil, com foco no acesso à graduação. 


\subsection{O CONCEITO AO ACESSO NA EDUCAÇÃO SUPERIOR}

Segundo o dicionário virtual Michaelis, o significado da palavra 'acesso' é: “aproximação, chegada, entrada, admissão, alcance”. Porém, o conceito ao acesso para a educação superior vai além do significado da palavra, pois considera regras que sustentam um modelo de abertura de espaço para o ingresso na educação superior. Esse 'caminho' é complexo porque envolve diversas perspectivas como orçamento, democratização, desigualdades de gênero e raças, perfil socioeconômico, entre outras.

O acesso ao Ensino Superior ainda é restrito à pequena parcela da população, sendo observada uma mudança no cenário nacional com políticas educacionais, como informa Velloso (2011). De acordo com o Censo da Educação Superior (INEP, 2013, p.3) em 2012, aproximadamente $15 \%$ dos jovens (18 a 24 anos) frequentaram o Ensino Superior. De acordo com o relatório, "fica claro que as políticas de inclusão em curso precisam ser mantidas e ampliadas para garantir igualdade de oportunidades educacionais para todos os brasileiros."

O Governo, representado pelo Ministério da Educação (MEC), inseriu expectativas relacionadas ao acesso ao Ensino Superior, por meio do PPA 2012-2015 (Programa 2032 - Educação Superior - Graduação, Pós-graduação, Ensino, Pesquisa Extensão), a saber:

\footnotetext{
ampliar e democratizar o acesso à educação superior de qualidade a partir do reconhecimento do papel estratégico das universidades para o desenvolvimento econômico e social do país é o principal objetivo do Ministério da Educação neste eixo de atuação. Proporcionar este nível de ensino a uma parcela maior da população é fator decisivo para a diminuição das desigualdades sociais e regionais, para o desenvolvimento científico e tecnológico, para a inclusão social e para a geração de trabalho e renda. (BRASIL/MEC, 2014, p. 77)
}

O acesso e todo o arcabouço de regras envolvendo, desde o alto escalão do governo até a execução nas universidades, é concretizado por meio de instrumentos designados de acordo com as formas ao acesso. As diretrizes macro foram definidas recentemente pelo MEC, com a aprovação do Plano Nacional de Educação (PNE) 2014-2024, Lei 13.005 de junho de 2014. Estados, Municípios e Distrito Federal devem segui-las para propor ações que contribuam para o alcance das metas. 
Posto isso, acesso pode ser entendido como um modelo de abertura para o ingresso no Ensino Superior, disponível para toda a população, em que, por meio de suas regras, busca direcionar a certos públicos alvo os quais são considerados reconhecidamente pelo governo como os com menos oportunidades. Há uma tentativa, por parte do governo, de promover equidade, utilizando o princípio da isonomia, ou seja, tratando os iguais como iguais e os diferentes como diferentes, bem exemplificado no PNE 2014-2012. A meta 14 estipula regras específicas ao acesso à pós-graduação, e a estratégia 14.5 diz respeito ao tema estudado: "14.5) implementar ações para reduzir as desigualdades étnico-raciais e regionais e para favorecer o acesso das populações do campo e das comunidades indígenas e quilombolas a programas de mestrado e doutorado. (Lei 13.005 de 25 de junho de 2014, p. 25)

O cenário nacional é favorável ao acesso ao ensino superior de forma geral, com o Programa Universidade para Todos, além do Prouni, do Fies, do Sistema de Seleção Unificada (SiSU), do Programa de Apoio a Planos de Reestruturação e Expansão das Universidades Federais (Reuni), da Universidade Aberta do Brasil (UAB) e da expansão da rede federal de educação profissional e tecnológica, os quais ampliam significativamente o número de vagas e contribuem para um maior acesso dos jovens à educação superior (BRASIL, 2014).

\subsection{AÇÃO AFIRMATIVA E A POLÍTICA DE PERMANÊNCIA ESTUDANTIL}

Em 2010 foi aprovado o Decreto n. ${ }^{\text {o } 7.234, ~ d e ~} 19$ de julho de 2010, instituindo o Programa Nacional de Assistência Estudantil (PNAES), com a finalidade de "ampliar as condições de permanência dos jovens na educação superior pública federal” $\left(\right.$ Art. $\left.1^{\circ}\right)$. Os objetivos do PNAES estão definidos no Art. $2^{\circ}$, alíneas de I a IV, das quais se destaca para este estudo as alíneas II e a IV, a saber: "II - minimizar os efeitos das desigualdades sociais e regionais na permanência e conclusão da educação superior; e IV - contribuir para a promoção da inclusão social pela educação". No Art. $4^{\circ}$, parágrafo único, insere-se a questão socioeconômica como critério para as ações de assistência estudantil, ao definir que deve ser considerada a "necessidade de viabilizar a igualdade de oportunidades, contribuir para a melhoria do desempenho acadêmico e agir, preventivamente, nas situações de retenção e evasão decorrentes da insuficiência de condições financeiras”. 
Por se tratar de parte da população com menor poder aquisitivo, o público negro é alvo das políticas de permanência nas universidades. Dessa forma, o PNAES, em tese, tem relação direta com as ações afirmativas no ensino superior. Porém, o referido programa, embora inicie de forma abrangente ao colocar a expressão "educação superior pública federal", é direcionado à graduação.

O sistema de cotas da graduação também adota o critério socioeconômico expresso na Lei 12.711/2013, como consta no Art. 1º Parágrafo único: 50\% (cinquenta por cento) das vagas ofertadas "deverão ser reservadas aos estudantes oriundos de famílias com renda igual ou inferior a 1,5 um salário-mínimo e meio per capita" (Lei no 12.711 de 29 de agosto de 2012, p. 1). Esse percentual é distribuído entre os grupos negros, pardos e indígenas da população, “em proporção no mínimo igual à da unidade da Federação onde está instalada a instituição, segundo o último censo do Instituto Brasileiro de Geografia e Estatística (IBGE)", segundo Art. $3^{\circ}$ da referida lei.

A definição ora citada não fora ocasional, e sim, resulta de constatações empíricas e estatísticas, demonstrando que esses grupos são os mais desfavoráveis socioeconomicamente, segundo classificação do BGE. Eles são formados pelos que representam a camada da sociedade atingida pelas discriminações e que fazem jus à justiça social, a qual as políticas públicas vêm buscando atingir (lacunas sociais). Barreto (2007) entende que o apoio à permanência tem atingido estudantes dos grupos historicamente excluídos do Ensino Superior.

No entanto, ambas as políticas públicas do governo - ações afirmativas e permanência - são direcionadas para a graduação. Isso implica dizer que não há previsão orçamentária para espelhar as mesmas práticas de estímulo ao acesso e de assistência estudantil na pós-graduação. Faz-se necessário fomentar as discussões sobre esses temas a fim de ampliar o acesso à população negra nos cursos de pós-graduação stricto sensu e contribuir para a sua permanência. A Associação Nacional do Pós-graduandos (ANPG) enfatiza a questão econômica para subsidiar essas duas demandas nas pautas das reuniões em que participam. 


\subsection{O IMPACTO DA DECLARAÇÃO E PROGRAMA DE AÇÃO DE DURBAN}

A 'Declaração e Programa de Ação de Durban' foi o produto do marco histórico III Conferência Mundial contra o Racismo, a Discriminação Racial, a Xenofobia e as Formas Conexas de Intolerância, realizada em Durban, na África do Sul, no período de 31 de Agosto a 8 de Setembro de 2001. Segundo Santos (2012), o resultado contribuiu para as seguintes mudanças: houve reconhecimento por parte do Brasil da existência de racismo, das suas consequências, bem como da necessidade de adoção de ações reparadoras desses impactos; a inclusão dessa temática na agenda do governo, uma importante conquista.

Segundo Santos et al (2008, p. 292), essa conferência contribuiu de forma decisiva para a luta antirracismo no Brasil uma vez que

(...) reconheceu a discriminação existente em países onde não ocorreu segregação e, como medida de reparação aos danos causados, fixou os fundamentos jurídicofilosóficos que legitimam a adoção de ações afirmativas que possam corrigir ou mitigar as desigualdades e promover a igualdade. Assim, a posição do Brasil em relação a Durban foi decisiva para o aquecimento do debate acerca das políticas de ações afirmativas.

Carvalho (2007) concorda e vai além, pois acredita que somente após a pressão internacional é que se expôs a existência de uma discriminação velada no Brasil. Como consequência, "muitos que diziam que nós não tínhamos racismo se calaram ou não encontraram mais oportunidades para se pronunciar com a mesma liberdade que se pronunciavam antes" (CARVALHO, op.cit., p. 17), referindo-se à postura dos professores acadêmicos brasileiros, os quais passavam a imagem equivocada ao exterior, com afirmações de que o racismo era uma questão superada no Brasil. Essa situação é elucidada no seguinte fragmento do texto:

uma quantidade de professores que andou dando conferências nos Estados Unidos, na Inglaterra, na França, contando uma mentira lá fora, a saber, que aqui as relações raciais eram ótimas, que o problema eram os Estados Unidos e a África do Sul. O Estado Brasileiro preparou uma elite para mentir sobre a natureza do país no exterior. Entretanto, no ano de 2000, depois que uma leva de intelectuais acadêmicos, sobretudo norte-americanos, veio ao país, descobriu-se que o que esses professores brasileiros falavam no exterior não condizia com a realidade. Esses intelectuais estrangeiros que nos visitaram disseram, em suma, que a realidade no Brasil, no que diz respeito às relações raciais, é bem pior do que o que fora apresentado. Consequentemente, pressionaram o Brasil a preparar um perfil a ser 
apresentado na reunião mundial contra o racismo na África do Sul. Essa interpelação do exterior levou o Ipea a juntar dados que muitas pessoas já sabiam sobre as nossas relações raciais. Só que esses dados apareceram na mídia, aqui está a novidade. Assim, muitos jornalistas, que provavelmente não tinham a clareza sobre esses dados porque sempre confiaram no que os professores universitários diziam, se surpreenderam com o grau de desigualdade racial entre nós. Logo, esses dados do Ipea foram decisivos para a ampliação da discussão de políticas públicas de combate às desigualdades entre nós. Então, o professor Roberto Martins, diretor do Ipea, se tornou uma figura conhecida nacionalmente porque ele andava pelo Brasil inteiro. Ele projetava na parede uns gráficos impressionantes sobre a exclusão racial. Todos os dados relativos ao emprego, à saúde, à escolaridade revelavam que quem é negro só leva desvantagem no Brasil. Os dados do Ipea são irrefutáveis. Eu nunca vi em nenhum lugar ninguém que tenha conseguido desmontar esses dados, ninguém que minimamente tenha se apresentado para contra-argumentar. Já se vão mais de dois anos que esses dados estão sendo distribuídos pelos jornais, na televisão e em todos os lugares. Então, a conferência de Durban certamente ajudou a luta antirracismo no Brasil (CARVALHO, 2007, p. 16-17).

Santos (2012, p. 290) corrobora com essa afirmação, dizendo que foi na Conferência de Durban que “o Estado Brasileiro reconheceu os efeitos do racismo e a necessidade de adoção de medidas que pudessem minimizar ou mitigar as consequências dos seus efeitos". O autor afirma ainda que foi a partir do referido evento que as políticas de ações afirmativas passaram a ser vivenciadas de forma mais sistêmica. Acredita-se, ainda, que "a posição do Brasil na Conferência da África do Sul foi determinante, pois passou a respaldar a reivindicação antiga e, também, a exigir de maneira mais contundente a adoção de tais políticas".

Portanto, a Declaração de Durban contribuiu de forma definitiva para a mudança do Brasil no que diz respeito ao posicionamento diante dessa questão, fomentando um debate e contribuindo para a construção das políticas públicas de ações afirmativas latentes, a partir de 2004, com o envio do Projeto de Lei n. 3 , o qual se tornou, em 2012, a Lei 12.711, chamada de lei das cotas, por reservar 50\% das vagas das instituições federais para egressos de escolas públicas, dividido entre pardos, negros e indígenas, proporcionais à composição dessas na unidade da federação (BRASIL, 2004).

\subsection{A SECRETARIA DE POLÍTICAS DE PROMOÇÃO DA IGUALDADE RACIAL}

A Secretaria de Políticas de Promoção da Igualdade Racial (SEPPIR, 2015) foi criada inicialmente pela Medida Provisória ${ }^{\circ}$ 111, de 21 de março de 2003, convertida, 
posteriormente, na Lei 10.678, de 23 de maio de 2003. De acordo com o sítio oficial do órgão, sua criação representou o reconhecimento das lutas históricas do movimento negro no Brasil tendo como papel "atuar em todas estas etapas de construção de políticas de ações afirmativas, por entender que as políticas públicas são fundamentais para tornar o Brasil um país justo e com oportunidades iguais para todos" (SEPPIR, 2015).

Ligada diretamente à Presidência da República quando criada, essa secretaria tinha como finalidade a formulação, a coordenação e a avaliação de políticas e diretrizes para a promoção da igualdade racial; a formulação e a coordenação das políticas públicas afirmativas de promoção da igualdade e da proteção dos direitos de indivíduos e grupos étnicos, com ênfase na população negra, afetada por discriminação racial e demais formas de intolerância. Além disso, visava também à articulação, promoção e acompanhamento da execução dos programas de cooperação com organismos nacionais e internacionais, públicos e privados, voltados à implementação da promoção da igualdade racial. Por fim, tinha como finalidade a o coordenação e acompanhamento das políticas transversais de governo para a promoção da igualdade racial; o planejamento, a coordenação da execução e a avaliação do Programa Nacional de Ações Afirmativas; o acompanhamento da implementação de legislação de ação afirmativa e definição de ações públicas que visem ao cumprimento de acordos, convenções e outros instrumentos congêneres assinados pelo Brasil, nos aspectos relativos à promoção da igualdade e combate à discriminação racial ou étnica.

Para a SEPPIR, as ações afirmativas não devem ser vistas como um benefício, ou algo injusto, e sim, como uma intervenção do Estado, necessária para minimizar injustiças históricas de escravidão, segregação racial e racismo contra a população negra e direitos não assegurados a ela.

\footnotetext{
"Ao debater as cotas para negros nas universidades é preciso retornar ao Brasil colonial e perceber como o processo de escravidão criou desigualdades sociais que são presentes até hoje, mesmo após 127 anos da abolição da escravidão. A partir de dados estatísticos que demonstram a diferença entre negros nas universidades comparados com o percentual desta população no total de brasileiros, o governo comprova a necessidade de criar uma política para compensar séculos de desigualdades. É assim que nasce uma política de ação afirmativa. Após a leitura de um diagnóstico sociocultural histórico, há a comprovação estatística das desigualdades existentes e da necessidade de reparos. Após o diagnóstico e o planejamento de uma política de ação afirmativa, os gestores governamentais encaminham a legislação, monitoram sua aprovação e implementação". (SEPPIR, 2015)
} 
Sua atuação tem como referência política o Estatuto da Igualdade Racial (Lei 12.288/2010), o qual orientou a elaboração do Plano Plurianual (PPA 2012-2015), resultando na criação de um programa específico intitulado 'Enfrentamento ao Racismo e Promoção da Igualdade Racial'. Resultou também na incorporação desses temas em 25 outros programas, totalizando 121 metas, 87 iniciativas e 19 ações orçamentárias, em diferentes áreas da ação governamental (SEPPIR, 2015).

Ainda no início do ano de 2015, surgiram notícias da possibilidade de extinção da SEPPIR, como consequência da reforma administrativa em resposta à crise fiscal observada. Segundo informação noticiada pela SEPPIR, no segundo semestre de 2015, a Presidente em exercício anunciou a fusão de três secretarias: a SEPPIR (Secretaria de Políticas de Promoção da Igualdade Racial), a SPM (Secretaria de Políticas para Mulheres) e a Secretaria de Direitos Humanos, passando-se a se chamar Ministério das Mulheres, Igualdade Racial e Direitos Humanos, sob a coordenação da ministra Nilma Lino Gomes, que estava à frente da SEPPIR.

A fusão foi interpretada como positiva sob perspectiva do governo, como verificado na afirmação do secretário Ronaldo Barros: "agora, com a nova estrutura, a Secretaria Especial de Políticas de Promoção da Igualdade Racial terá a oportunidade de fazer uma articulação maior com pautas importantes" (SEPPIR, 2015). Sob a perspectiva do movimento negro, essa fusão foi vista como negativa, como se pode observar no sítio da Revista Fórum, na opinião de Dennis de Oliveira, professor da Escola de Comunicação e Artes da Universidade de São Paulo (ECA/USP), a saber: “(:)a perda de status de ministério destas secretarias dificultará o caráter transversal dessas políticas e reduzirá a sua visibilidade". A revista argumenta ainda que

\footnotetext{
apesar da ministra Nilma ser oriunda da SEPPIR, ela terá que dar conta das demandas de três secretarias que estarão sob o seu ministério. E a tendência é vincular as políticas de combate ao racismo a temática dos direitos humanos e cidadania, isto é, circunscrevê-las no âmbito dos direitos civis. Do ponto de vista de uma concepção de racismo estrutural, isto é retrocesso. O racismo se manifesta em todas as dimensões da vida social - no trabalho, na saúde, na educação, nos direitos sociais -, se expressa nas instituições (o chamado racismo institucional) e se legitima ideologicamente (o racismo ideológico). Isto exige um compromisso firme por meio de políticas de Estado (e não apenas de governo) no sentido de combater tenazmente o racismo. Transcende, portanto, a concepção de direitos civis e de cidadania. Ainda que de forma tímida, a visibilidade que a temática racial foi ganhando no campo institucional com o funcionamento da SEPPIR e suas articulações com outros ministérios, possibilitou que a temática fosse contaminando outras áreas (FORUM, 2015).
} 


\subsubsection{As Primeiras Experiências de Ações Afirmativas Amparadas por Leis nas Universidades Públicas}

A legislação brasileira reflete a convergência entre os temas ensino superior e igualdade racial, fomentando a discussão e a pesquisa que os envolve. Esse pode ser considerado com um ponto forte para a compreensão do que está sendo proposto neste estudo.

De acordo com Santos (2012, p. 290), datada de 1948, a Declaração Universal dos Direitos Humanos, "pode ser identificada como marco universal em defesa e justificação das ações afirmativas", e suas contribuições "foram determinantes para a inclusão da temática na agenda política".

A lei geral e orgânica da educação brasileira é a Lei de Diretrizes e Bases da Educação Nacional (LDBEN), n. ${ }^{\circ}$ 9394/96, a qual estabelece as diretrizes e as bases da organização do sistema educacional brasileiro. Ela tem como característica não ser detalhista, o que dá muita liberdade para as instituições dos sistemas de ensino municipais, estaduais e federal, conforme observa-se em seu parágrafo $2^{\circ}$ do art. $8^{\circ}$ da referida lei: “a União, os Estados, os Municípios e Distrito Federal podem organizar seus respectivos sistemas de ensino".

A Constituição Federal de 1988 também legitima a autonomia universitária em seu art. 207: "as universidades gozam de autonomia didático-científica, administrativa e de gestão financeira e patrimonial, e obedecerão ao princípio de indissociabilidade entre ensino, pesquisa e extensão". O reflexo dessa característica é à heterogeneidade das ações afirmativas praticadas em todos os níveis da federação.

Após a conferência, algumas leis estaduais foram criadas, revelando que os estados foram pioneiros na concretização dessa transformação, implantando ações afirmativas, sendo que o Rio de Janeiro e a Bahia ganham destaque. A Universidade Estadual da Bahia (UNEB) foi a primeira a implantar uma ação afirmativa na modalidade sistema de cotas, em 2002, reservando $40 \%$ das vagas para negros egressos da rede pública de ensino, e, outros $5 \%$ para indígenas, do total de vagas ofertadas pela universidade em todos os cursos de graduação e pós-graduação. 
Dois marcos do sistema de cotas da UNEB merecem destaques: 1) a universidade incluiu ações afirmativas de estímulo para acesso aos negros na pós-graduação desde o início, diferente das demais, as quais se restringiram ao âmbito da graduação; 2) interessante também é o fato da instituição ter a primeira reitora negra a dirigir uma universidade no país, na pessoa da Ivete Sacramento, que implantou as cotas para negros na UNEB, em 2002, no país.

A Lei 4151, de 04 de Setembro de 2003, levou a Universidade Estadual do Rio de Janeiro (UERJ) também a adotar o sistema de cotas, destinando 50\% de suas vagas no vestibular de 2003 para estudantes que cursaram o Ensino Médio em escolas da rede pública, incluindo cota para afrodescendentes, porém sem a inclusão do critério socioeconômico, a princípio.

Posteriormente, a Lei 5074/2007 incluiu outros grupos a terem direito à reserva de vagas. Em dezembro de 2008, a Assembleia Legislativa do Estado do Rio de Janeiro decretou e sancionou a Lei 5346/08, que estabelece, nos artigos $1^{\circ}, 2^{\circ}$ e $3^{\circ}$, o modelo praticado até hoje: " $20 \%$ (vinte por cento) para os estudantes negros e indígenas; $20 \%$ (vinte por cento) para os estudantes oriundos da rede pública de ensino; 5\% (cinco por cento) para pessoas com deficiência, nos termos da legislação em vigor, e filhos de policiais civis, militares, bombeiros militares e de inspetores de segurança e administração penitenciária, mortos ou incapacitados em razão do serviço" (UERJ, 2014).

Nessa seara de ações afirmativas, a Universidade Estadual do Mato Grosso do Sul - UEMS - também foi pioneira ao incluir reserva de vagas para negros, por meio da Lei n. ${ }^{\circ}$. 2.605, de 06 de Janeiro de 2003. Assim, determinou a reserva de $20 \%$ das vagas para negros nas Instituições de Ensino Superior (IES) do Estado.

Na esfera Federal, a Universidade de Brasília foi à primeira entre as instituições federais de ensino superior a implantar ação afirmativa de combate às desigualdades étnicoraciais, também na modalidade de sistema de cotas para ingresso na graduação, desde o vestibular de 2004. Em seu relatório de avaliação, dos 10 anos dessa política, a UnB considera que "os dados sistematizados pelo CESPE mostram que a decisão do CEPE da UnB de implantar as cotas para negros e indígenas a partir do $2^{\circ}$ semestre de 2004 foi uma medida justa e necessária para diminuir a desigualdade étnica e racial no ensino superior brasileiro" (UNB, 2013, p. 36). 
Nesse processo, houve discussão para definição da ação afirmativa, num relato de Carvalho (2007), que expõe a dificuldade em obter quorum nas reuniões, relatando ter havido contribuição de personagens importantes nessa luta como a da Edna Roland, que participou da III Conferência de Durban, como relatora, e uma participação de Joaquim Barbosa, então jurista, que se tornou o primeiro presidente negro do Superior Tribunal Federal do Brasil. Carvalho afirma:

\begin{abstract}
fizemos um debate em Março. Nesse debate, chamamos Edna Roland, uma autoridade internacional que foi relatora da conferência de Durban; chamamos o Ivair dos Santos, do Ministério da Justiça; Roberto Martins, do Ipea. O Conselho Universitário são cinquenta membros. Nessa reunião, com o fim de discutir cotas, apareceram dois professores. Os professores resolveram não comparecer à reunião, este foi o artifício deles. Agora, no mês de Julho, fizemos a segunda rodada, convidamos Joaquim Barbosa Gomes, que é um jurista brasileiro e ex-aluno da UnB. Ele é o único negro nos tribunais superiores, o único negro na parte superior do Poder Judiciário, ele tem um livro escrito sobre ação afirmativa. Joaquim Barbosa falou e defendeu novamente o nosso projeto de cotas perante oito professores dos cinquenta do Conselho Universitário. Então, o reitor não tem como pôr em pauta a votação, porque aqueles que têm de votar não querem ouvir os argumentos. Em geral, os argumentos contra as cotas são argumentos muitos débeis. Então, como eles não têm argumento, a arma maior é não ir, não comparecer para ver se esse assunto morre, para ver se ele desaparece e os privilégios continuam do jeito que estão. Não é que as pessoas são contra as cotas porque tenham algum argumento verdadeiro. Elas simplesmente são contrárias porque, se abrirem cotas para os negros, vão diminuir as cotas para as pessoas brancas: os filhos deles que querem entrar na universidade. É simples, eles vão perder uma parte dos privilégios que não querem perder (CARVALHO, 2007, p. 28-29).
\end{abstract}

Para Santos (2012, p. 300), a “UnB foi responsável por dar início a um processo que vem se expandindo gradualmente em todas as regiões do Brasil, e que culminou com a aprovação da Lei 12.711 de 2012”, a Lei Federal de Cotas. Houve uma audiência pública no Supremo Tribunal Federal (STF), em 2012, para julgar a constitucionalidade da política de reserva de vagas nas universidades. A aprovação da constitucionalidade das políticas afirmativas fomentou a aprovação da Lei 12.711 de 2012. Segue um exemplo de cálculo, seguindo os critérios determinados por essa lei. 
Figura 2 - Exemplo de Cálculo da Lei de Cotas

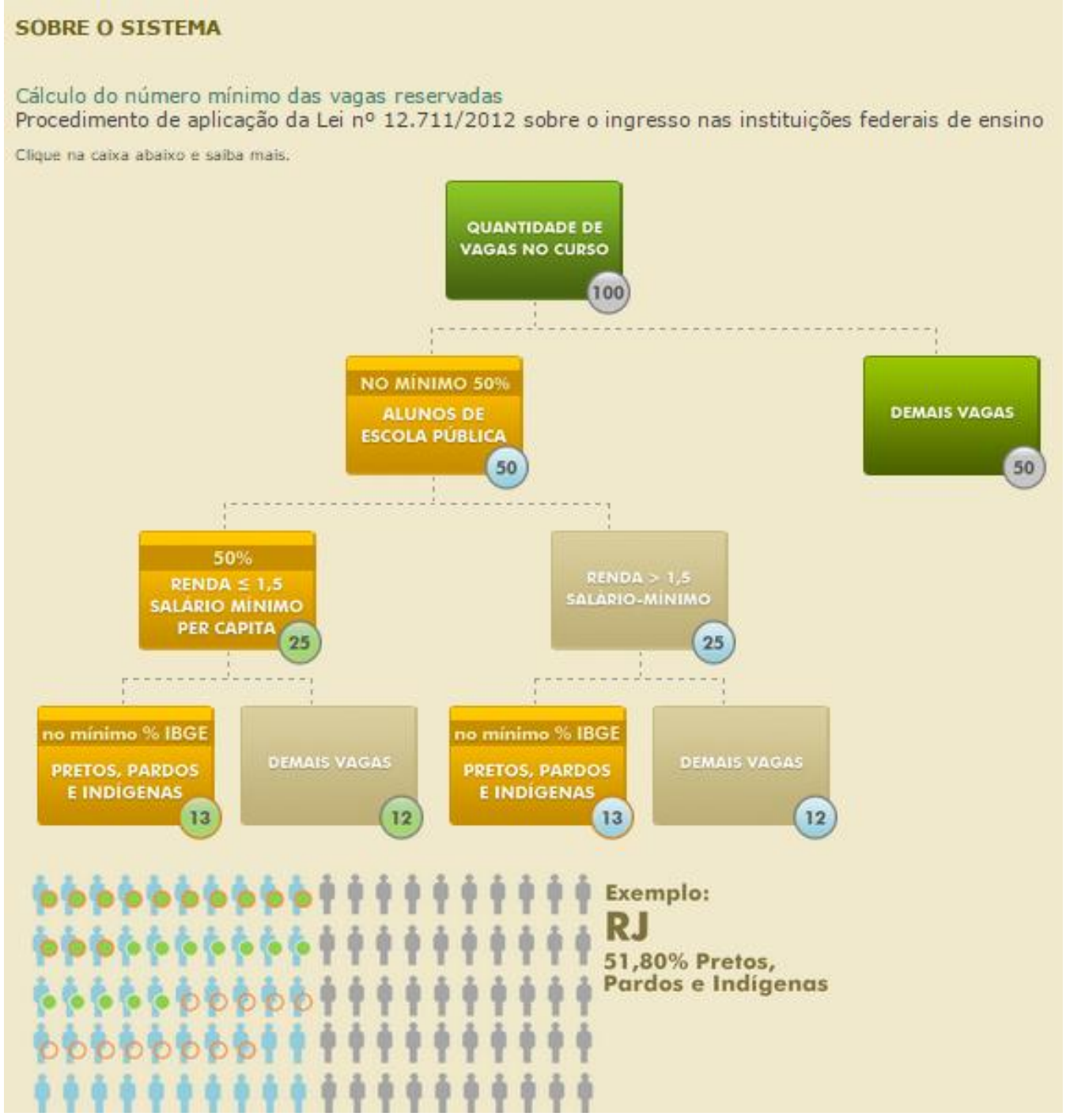

Fonte: <http://portal.mec.gov.br/cotas/sobre-sistema.html> Acesso em: 13/12/2014

Fica evidente com o exemplo que a lei estipulou a reserva de $50 \%$ das vagas das universidades federais para estudantes de escola pública, e dentro dessa reserva, destinou um percentual para estudantes pretos e $\operatorname{pardos}^{5}$ e indígenas, de acordo com a proporção da população do Estado.

A UnB avalia que essa lei, implementada desde o primeiro semestre de 2013, "significa um retrocesso, enquanto política de inclusão étnica e racial, quando comparada com

\footnotetext{
${ }^{5}$ Segundo a classificação de cor ou raça do IBGE “ a agregação de pretos e pardos e sua designação como negros justificam-se duplamente. Estatisticamente, pela uniformidade de características socioeconômicas dos dois grupos. Teoricamente, pelo fato de as discriminações, potenciais ou efetivas, sofridas por ambos os grupos, serem da mesma natureza. Ou seja, é pela sua parcela preta que os pardos são discriminados. A justificava teórica é obviamente mais importante, pois ao fornecer uma explicação para a origem comum das desigualdades dos pretos e dos pardos em relação aos brancos, coloca os dois grupos como beneficiários legítimos de quaisquer ações que venham a ser tomadas no sentido de reverter o quadro histórico e vigente dessas desigualdades. (www.ipea.gov.br/portal/images/stories/PDFs/TDs/td_0996.pdf);
} 
o sistema de cotas específico da UnB que, por sua vez, é amplamente reconhecido como o mais avançado nacionalmente" (UNB, 2013, p. 37).

A Universidade Federal de Minas Gerais (UFMG) também merece destaque nesse cenário, pois inovou, implantando uma ação afirmativa diferente: adotou a modalidade programa de bônus, em que atribui um percentual adicional às notas dos beneficiários. Inicialmente em caráter experimental - e motivada pelas ações afirmativas implantadas no estado do Rio de Janeiro - em 2003, durante quatro anos, "implantou a aplicação de bônus adicionais ao desempenho no vestibular para estudantes oriundos de escolas públicas e que se declarem pretos ou pardos, política implantada para vigorar a partir de 2009" (PEIXOTO e BRAGA, 2012, p. 169).

O modelo consistia em acrescentar às notas de ambas as etapas do vestibular $10 \%$ ou de $15 \%$ à nota dos estudantes que comprovassem haver cursado todo o Ensino Médio, e pelo menos as quatro últimas séries do Ensino Fundamental em escolas públicas: 10\% de bônus para estudantes egressos de escolas públicas, sendo necessária a comprovação, após a aprovação no vestibular; $15 \%$ de bônus para aqueles que se autodeclararam pretos ou pardos, bastando a autodeclaração, sem exigência de comprovação no ato da inscrição.

Em se tratando de pós-graduação, a UNEB foi a primeira a incluir ações afirmativas desde o início, em 2002. A UnB avança nesse sentido, pois adota reserva de vagas para negros em quatro programas de pós-graduação, e, o Centro de Desenvolvimento Sustentável (CDS) introduziu no mestrado uma inovação ao oferecer quinze das trinta vagas ofertadas, destinadas a candidatos que se autodeclarasse indígena e quilombola, na seleção de primeiro semestre de 2015, (segunda turma) com bolsas de estudo. Na primeira turma, incluíram-se apenas os indígenas (UNB, 2014).

Um movimento vem ocorrendo como consequência da imposição da Lei das Cotas para a graduação em 2012, que é a implantação e reservas de vagas de mestrado e doutorado em cursos de departamentos de universidades (unidades acadêmicas), iniciativas isoladas, visto que não há uma política pública institucional de estímulo para acesso à população negra na pós-graduação stricto sensu. A UNEB, na esfera estadual, foi à única que implantou, desde 2002, o modelo abrangendo graduação e pós-graduação. A partir de 2014, duas universidades federais tiveram iniciativas de adotar sistema de cotas. Tais iniciativas 
isoladas de unidades acadêmicas tiveram o apoio da instituição a que pertencem. A primeira foi a UFRJ, programa de Antropologia Social do Museu Nacional e a segunda foi a UnB que implantou quatro programas, três em 2015, e um em fase de seleção para implantação em 2016.

Outras iniciativas confirmam a tendência de ampliar o sistema de cotas na pósgraduação em forma de lei. As universidades federais UFAL, UFSC, UFPel e UFPA oferecem reserva de vagas em cursos de Antropologia, Sociologia e Direito. A Universidade da Integração Internacional da Lusofonia Afro-Basileira - UNILAB -, abrangida pelos Estados do Ceará e da Bahia, oferece um mestrado interdisciplinar que mescla Agronomia, Saúde e Engenharia (ANDIFES, 2014). 


\section{PERCURSO METODOLÓGICO}

Sampieri et al (2006) afirmam que pesquisa tem relação direta com a realidade, o que pode ocorrer no cotidiano das pessoas informalmente ou de forma científica, sendo essa última mais rígida, organizada e realizada meticulosamente. Dessa forma, “(:) a pesquisa científica supõe uma conjunção de teoria e averiguação de fatos particulares" (ALYRIO, 2009, p. 58).

A presente Dissertação tem como característica um distanciamento da pesquisadora com relação ao tema uma vez que não faz ou fez parte de nenhum dos movimentos que circundam o tema. Portanto, a motivação para realizar este estudo foi o desafio de investigar um tema proposta feita pela orientadora, pouco discutido, sobre o qual tem pouca literatura específica. Esse contexto leva à compreensão da perspectiva abordada somada à formação da autora em Administração privilegiando estudos sob óptica das insituições.

Portanto, para o campo da Administração, de acordo com Hair et al (2005, p.13) por meio da pesquisa, é possível "converter uma simples informação em inteligência". O autor afirma ainda que "pesquisa é uma busca com o objetivo de discernir a verdade. Aqueles que realmente pesquisam estão procurando por respostas” (HAIR et al, op.cit., p. 20).

A pesquisa em Administração é uma investigação científica que tem como foco a verdade dos acontecimentos, ou 'fenômenos administrativos', que envolvem pessoas, e é por isso que seus agentes têm mais afinidade com os cientistas sociais. A pesquisa busca, ainda, entender todo o ambiente administrativo, considerado em seu dinamismo, por meio desses fenômenos com análise, interpretação e relatos das informações, a fim de subsidiar tomadas de decisões administrativas mais eficazes (HAIR et al, op.cit. p. 31).

Outra abordagem em Administração convergente com a apresentada é a definição de 'fato administrativo', apresentada por Alberto Guerreiro Ramos em sua obra intitulada ‘Administração e Contexto Brasileiro: esboço de uma teoria geral da administração", em que 
afirma que

podemos dizer que é um complexo de elementos e suas relações entre si, resultante e condicionante da ação de diferentes pessoas, escalonadas em diferentes níveis de decisão, no desempenho de funções que limitam e orientam atividades humanas associadas, tendo em vista objetivos sistematicamente estabelecidos. (RAMOS, 1983, p. 7)

Nessa definição, o autor atribui à característica 'dinamismo', quando afirma que “está em permanente atualização, por força do desempenho consciente e ininterrupto dos agentes que constituem dele elemento capital" (RAMOS, 1983, p. 7).

Diante disso, este estudo considera a ampliação ao acesso à população negra em PPGs como um fato administrativo, por ter as características de sua definição: complexo de elementos e suas relações entre si; ação de diferentes pessoas; diferentes níveis de decisão; funções que limitam e orientam atividades humanas associadas; e, em vistos objetivos sistematicamente estabelecidos.

A Universidade de Brasília, embora estabelecida há 54 anos pela Lei 3.998/1961, há apenas 16 anos possui uma política de inclusão de negros nos cursos de graduação, implantada de forma institucional, com análise dos seus 10 anos realizada em 2014. Neste trabalho, a intenção foi verificar se a UnB tem se esforçado institucionalmente para atender às demandas por uma política pública de ação afirmativa que estimule a ampliação ao acesso da população negra aos cursos de pós-graduação stricto sensu.

Constatando-se que a UnB tem pouco mais que uma década de experiência com uma política pública de ampliação ao acesso aos negros, com foco apenas na graduação. Embora algumas universidades estaduais (UFRJ, UNEB, entre outras) tenham sido as primeiras a implantarem uma política pública com a mesma finalidade, a UnB ganhou importância no cenário nacional dando visibilidade às ações afirmativas ao se tornar pioneira na esfera federal. Sua experiência contribuiu, inclusive, para a criação da Lei 12.711/2012, transcrita abaixo.

Art. $1^{\underline{0}}$ ) As instituições federais de educação superior vinculadas ao Ministério da Educação reservarão, em cada concurso seletivo para ingresso nos cursos de graduação, por curso e turno, no mínimo $50 \%$ (cinquenta por cento) de suas vagas para estudantes que tenham cursado integralmente o Ensino Médio em escolas públicas. 
Parágrafo único. No preenchimento das vagas de que trata o caput deste artigo, 50\% (cinquenta por cento) deverão ser reservados aos estudantes oriundos de famílias com renda igual ou inferior a 1,5 salário-mínimo (um salário-mínimo e meio) per capita. (Lei ${ }^{\circ} 12.711$ de 29 de agosto de 2012, p. 1)

Conforme a Lei 12.990/2014, que desencadeou a reserva de vagas para negros em concursos públicos,

Art. $1^{\circ}$ - Ficam reservadas aos negros $20 \%$ (vinte por cento) das vagas oferecidas nos concursos públicos para provimento de cargos efetivos e empregos públicos no âmbito da administração pública federal, das autarquias, das fundações públicas, das empresas públicas e das sociedades de economia mista controladas pela União, na forma desta Lei (lei $n^{\circ} 12.990$, de 9 de junho de 2014, p. 1).

O relatório de avaliação dessa experiência sinaliza que dos negros que ingressaram via sistema de cotas e que concluíram a graduação, a maioria não havia ingressado em cursos de pós-graduação stricto sensu.

Além disso, o MEC, por meio do Plano Nacional de Educação, estipulou a meta “14.5) implementar ações para reduzir as desigualdades étnico-raciais e regionais e para favorecer o acesso das populações do campo e das comunidades indígenas e quilombolas a programas de mestrado e doutorado" (Lei n. ${ }^{\circ} 13.005$, de 25 de junho de 2014, p. 25). É algo recente, mas que demonstra um movimento por parte do governo, no sentido de avançar para uma política pública institucional.

Embora em meio a uma crise econômica observada no Brasil, parte-se do entendimento de que o cenário desenhado até 2015 foi favorável à extensão de políticas púbicas sociais, as quais abrangem as ações afirmativas. Além da iniciativa do governo (meta 14.5 do PNE/2014), há pressão por parte de estudantes, tanto nas unidades acadêmicas, quanto de forma articulada com a Associação Nacional dos Pós-graduandos (ANPG), trazendo visibilidade e incluindo o tema na agenda das universidades e do governo. Os cursos também pressionam as IFES a instituírem uma política a fim de fazer justiça social. Com isso, começa a aumentar a discussão acerca do assunto, reforçado com as primeiras iniciativas nas universidades a partir de 2012, quando o sistema de cotas na graduação completou 10 anos.

Posto isso, foram analisadas as ações de ampliação ao acesso da população negra em cursos de pós-graduação stricto sensu entre 2004 a 2015, com aprofundamento na Universidade de Brasília. 
Grawitz (1975, p. 81) afirma que as pesquisas são divididas em dois grandes blocos: etapas preliminares e etapas finais. As etapas preliminares compreendem a preparação, quando a ideia é concebida e transformada em um plano de investigação; e quanto ao levantamento bibliográfico, por meio do conhecimento acumulado acerca do tema - ao definir o objetivo, é prudente inteirar-se do que já fora estudado sobre o mesmo problema, e sobre outros que tenham o mesmo local trazendo dados similares; as técnicas são adotadas para atingir cada objetivo específico, que deverá atingir o objetivo geral. Já as etapas finais compreendem as de análise e interpretação dos resultados.

Hair et al (2005, p. 76) apresentam a divisão da pesquisa em três fases: Formulação; Execução; Análise. A primeira fase, 'formulação' compreende "a definição da substância e do processo de pesquisa", e inicia-se com a leitura da literatura e documentos sobre o tema. Nesta Dissertação, essa fase foi representada a partir da construção da introdução, contendo definição dos objetivos até a revisão da literatura. A segunda, 'execução', é a reunião de informações a serem verificadas, codificadas e armazenadas para análise, partindo do percurso metodológico até a definição das técnicas de coletas de dados. A terceira fase, 'análise' dos dados obtidos e dos resultados fornece respostas às questões de pesquisa, e compreende a parte final desde as técnicas de análise de dados (HAIR et al, 2005, p. 76).

Dessa forma, o plano de pesquisa foi construído ancorado nos princípios metodológicos descritos ao longo de todo o texto, seguindo o modelo de 'Processo de Pesquisa em Administração' de Hair et al (2005, p. 76), contendo as três fases já mencionadas: Formulação; Execução; Análise. Perceba que está tudo interligado, e se trata de um processo de pesquisa realmente representada pela figura 3 :

Figura 3 - Representação do Processo de Pesquisa

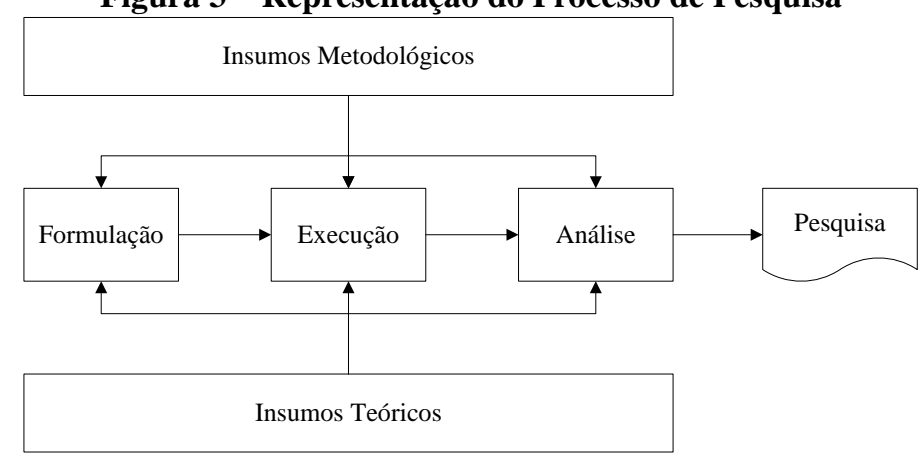

Fonte: Hair et al (2006) 
A fase de formulação permitiu a identificação de duas dimensões interrelacionadas em que está contida a pesquisa. Uma caracteriza-se como histórico, é mais ampla, e contextualiza as políticas públicas de ações afirmativas na educação superior. Essa fase abrange a graduação e a pós-graduação stricto sensu, bem como aspectos cuja compreensão é necessária para o entendimento do tema. A outra caracteriza-se como ações afirmativas na pós-graduação stricto sensu, foco do estudo.

Ambas as dimensões tem como objeto de estudo o fenômeno das políticas de ações afirmativas na educação superior no Brasil. A delimitação temporal, compreendendo os anos entre 2004 a 2015, foi definida partindo-se da premissa de que foi nessa fase em que ocorreram avanços, até atingir maturidade dessas práticas, observada pela experiência de mais de dez anos na graduação. Foi também a partir de 2012 que surgiram iniciativas na pósgraduação stricto sensu. O aprofundamento da pesquisa teve como lócus a Universidade de Brasília, cuja escolha foi motivada pelo seu importante papel na visibilidade das ações afirmativas e pela viabilidade ao acesso aos entrevistados.

Para analisar as ações de ampliação ao acesso da população negra a cursos de pósgraduação stricto sensu da Universidade de Brasília entre 2004 a 2015, foram utilizados recursos metodológicos de acordo com as duas dimensões. A análise de conteúdo foi aplicada para analisar as entrevistas, a fim de atingir os objetivos 2, 3 e 4 desta Dissertação, prioritariamente. A análise documental, complementar à análise de conteúdo, permeia por todos os objetivos específicos, priorizando, no entanto, o objetivo 1.

Segundo preconiza Grawitz (1975, p. 363), sobre análise de conteúdo, as categorias são mais ou menos previsíveis. Por isso, foram previstas as categorias de forma antecipada, baseadas na contextualização do fenômeno estudado. Entretanto, a sua definição não ocorreu de forma aleatória, mas foi guiada pelo objetivo da pesquisa.

As categorias teóricas foram interligadas às dimensões e aos objetivos específicos, e ancoradas pela revisão teórica. As perguntas elaboradas para as entrevistas semiestruturadas foram elaboradas baseadas nas categorias teóricas as quais guiaram a definição das categorias finais. 
Quadro 1 - Relação Entre Dimensões x Categorias Teóricas e Objetivos Específicos

\begin{tabular}{|c|c|c|c|c|c|}
\hline \multicolumn{2}{|r|}{ Dimensão } & \multicolumn{2}{|c|}{ Categoria Teórica } & \multicolumn{2}{|r|}{ Objetivo Específico } \\
\hline \multirow{2}{*}{$\mathbf{I}$} & \multirow{2}{*}{ Histórico } & 1 & Políticas Públicas & 1) & $\begin{array}{l}\text { Descrever o histórico das políticas públicas de educação } \\
\text { superior que adotam ações afirmativas praticadas nas } \\
\text { universidades públicas do Brasil. }\end{array}$ \\
\hline & & 2 & Boas Práticas & 4) & $\begin{array}{l}\text { Descrever/caracterizar as boas práticas das políticas de } \\
\text { ações afirmativas em Programas de Pós-graduação stricto } \\
\text { sensu. }\end{array}$ \\
\hline \multirow[b]{2}{*}{ II } & \multirow{2}{*}{$\begin{array}{l}\text { Ações } \\
\text { Afirmativas }\end{array}$} & 3 & $\begin{array}{l}\text { Ações } \\
\text { Afirmativas }\end{array}$ & 2) & $\begin{array}{l}\text { Descrever as ações afirmativas adotadas na Universidade } \\
\text { de Brasília para acesso de negros em cursos de pós- } \\
\text { graduação stricto sensu, no período de } 2004 \text { a } 2015 \text {. }\end{array}$ \\
\hline & & 4 & Acesso & 3) & $\begin{array}{l}\text { Identificar as dificuldades ao acesso da população negra } \\
\text { aos Programas de Pós-graduação stricto sensu ofertados } \\
\text { pela Universidade de Brasília sob a perspectiva da } \\
\text { instituição. }\end{array}$ \\
\hline
\end{tabular}

Fonte: Elaborado com dados da pesquisa, em 2015

Na sequência, discorrem-se mais detalhes a respeito do percurso metodológico adotado pela pesquisa.

\subsection{ABORDAGEM DA PESQUISA}

Esta pesquisa tem cunho exploratório e descritivo com relação ao processo. Embora a Universidade de Brasília tenha experiência de 10 anos de adoção de uma política de ação afirmativa (sistema de cotas), seu foco tem sido a graduação, com muitos estudos e conhecimentos identificados. Porém, constata-se que poucas ações têm sido adotadas institucionalmente entre 2004 a 2015, para ampliar o acesso de alunos negros aos cursos de pós-graduação stricto sensu.

Dessa forma, a pesquisa exploratória visa, em sua essência, familiarizar-se com um assunto "desconhecido, pouco estudado ou novo". Já seu caráter descritivo "serve para analisar como é e como se manifestam um fenômeno e seus componentes" (SAMPIERI et al, 2006, p. 112), uma vez que se pretendeu buscar "essencialmente a enumeração e a ordenação de dados, sem o objetivo de comprovar ou refutar hipóteses exploratórias, abrindo espaço para uma nova pesquisa explicativa, fundamentada na experimentação” (ALYRIO, 2009, p. 58). 
Neste estudo, prevaleceu o enfoque qualitativo da pesquisa, por meio de um processo dinâmico entre constatações de fatos e suas interpretações, como esclarece Sampieri et al (2006). O objetivo segue a colocação do autor em entender o fenômeno social considerado complexo, como é o acesso da população negra em Programas de Pós-graduação stricto sensu.

Uma pesquisa qualitativa se reflete no "estudo de um objeto, buscando interpretálo em termos do seu significado. Nesse sentido, a análise considera mais a subjetividade do pesquisador" (ALYRIO, op.cit., p. 108). Leva-se em consideração a visão global, podendo não contar com o enfoque estatístico e utilizar discussões em grupo e entrevistas para análise. Para Grawitz (1975), a pesquisa qualitativa deve ser feita de forma rigorosa, ancorada em sua correta construção, desde o plano até o aspecto formal das técnicas recorridas.

Sob o enfoque da Administração, trata-se de pesquisa básica por ser "motivada por um desejo de entender melhor alguns fenômenos relativos à Administração", uma vez que, "auxilia a desenvolver a teoria que tenta descrever e prever eventos administrativos de modo que todos os responsáveis pelas decisões administrativas possam beneficiar-se" (HAIR et al, 2005, p. 33).

A ciência descreve a realidade de forma pura, sendo que ela é o conhecimento que se tem sobre certo assunto adquirido por meio do método científico pelos pesquisadores. De forma análoga, "o processo de pesquisa básica em Administração busca descrever as realidades de ações e interações administrativas de um modo verdadeiro" (HAIR et al, op.cit., p. 80).

\subsection{TÉCNICAS DE COLETAS DE DADOS}

Para Hair et al (2005, p. 152), a coleta de dados nas abordagens qualitativas são empregadas no "estado exploratório do processo de pesquisa", tendo como finalidade "identificar e/ou refinar problemas de pesquisa que podem ajudar a formular e testar estruturas conceituais". A etapa de coleta de dados implica em: selecionar um instrumento ou 
método 'válido e confiável': aplicá-lo a fim de obter observações, contextos, categorias, etc. de interesse ao estudo; e, preparar tudo para correta análise (SAMPIERI et al, 2006, p. 286).

Para coletar os dados que permitissem aprofundar a questão na Universidade de Brasília, foi utilizada a técnica de coleta de dados em entrevistas semiestruturadas. Já para obtenção dos dados necessários para o histórico e as boas práticas, objetivos específicos 1 , principalmente, e demais complementariamente, foi aplicada a técnica análise documental.

\subsubsection{Análise documental}

O registro em documentos oferece inúmeras possibilidades, temas variados, lócus diversificado, entre outras características as quais tornam esta exploração rica, ao mesmo tempo que requer a aplicação de técnicas para imprimir o rigor científico. $\mathrm{O}$ investigador não tem controle sobre a forma como o documento foi criado, por isso é necessário selecionar o que interessa à investigação, interpretar ou comparar os materiais, para torná-los utilizáveis, como sugere Grawitz (1975).

A análise documental pode ser definida como "uma operação ou um conjunto de operações que visam representar o conteúdo num estado ulterior a sua consulta e referenciação". Ela tem como objeto os documentos, e objetiva representar as informações de forma sintética para "consulta e armazenamento" (BARDIN, 2004, p. 40). Essa técnica permite transformar documentos primários em secundários.

Os documentos se dividem em oficiais e particulares. Segundo Grawitz (1975), os primeiros são arquivos públicos considerados uma fonte rica de informações, porém com limitação de disponibilidade, principalmente. Já os segundos se referem, de acordo com Grawitz (op.cit.), à documentação das instituições, como por exemplo, políticas (partidos, etc.), profissionais (sindicatos, etc.), etc.

Essa técnica foi aplicada a fim de complementar a análise de conteúdo, principalmente quanto à obtenção dos dados necessários para o histórico e as boas práticas, objetivos específicos 1 e 2, e demais complementariamente ao 3 e 4. Para tanto, foi 
consultado um total de 308 documentos, sendo:

- 11 Documentos Governamentais;

o Parecer CFE no 977/65, aprovado em 3 de Dezembro de 1965: Definição dos cursos de pós-graduação pelo Conselho Federal de Educação, vinculados ao Ministério da Educação e Cultura;

○ Declaração Universal dos Direitos Humanos (1948);

○ Declaração de Durban: Declaração e Programa de Ação, adotada em 8 de Setembro de 2001, em Durban, África do Sul;

○ O Sistema de Classificação de "Cor ou Raça" do IBGE/IPEA. Brasília. 2003

○ Plano Nacional de Pós-graduação - PNPG 2011-2020. Brasília. CAPES, 2010, 2v.;

o Programa de Gestão de Políticas Públicas em Gênero e Raça. Rio de Janeiro: CEPESC 2011;

○ IPEA: Faces da desigualdade de gênero e raça no Brasil;

○ Mestres 2012: Estudos da demografia da base técnico-científica brasileira. Centro de Gestão e Estudos Estratégicos (CGEE), Brasília, 2012 (Organização Social supervisionada pelo Ministério da Ciência, Tecnologia e Inovação (MCTI));

- Plano Nacional de Políticas para Mulheres. Secretaria de Políticas para Mulheres, 2013.

- Relatório de Comunicação à Comissão Mista de Planos, Orçamentos Públicos e Fiscalização do Congresso Nacional (CMO). Alterações do Plano Plurianual 2012-2015. Brasília;

○ INEP: Resultados do Censo da Educação Superior 2013;

- 12 Leis;

○ Lei no 3.998/1961: Institui a Fundação Universidade de Brasília;

○ Lei $n^{\circ}$ 9.394/1996: Lei de Diretrizes e Bases da Educação Nacional (LDBEN);

○ Constituição Federal 1988;

○ Lei $\mathrm{n}^{\circ} 2.605$, de 06 de Janeiro de 2003. Sistema de cotas. UEMS;

○ Lei no 10.678, de 23 de Maio de 2003. Cria a SEPPIR;

○ Lei 4151 de 04 de Setembro de 2003. Sistema de cotas RJ; 
○ Lei $n^{\circ} 5074$ de 17 de junho de 2007. Revoga a 4151/2003 com relação à PNE;

○ Lei $n^{\circ}$ 5346, de 11 de Dezembro de 2008. - Modelo Sistema de Cotas RJ vigente;

- Lei n 12.288 , de 20 de julho de 2010, Estatuto da Igualdade Racial;

○ Lei $\mathrm{n}^{\circ} 12.990$, de 9 de junho de 2014, Reserva $20 \%$ das vagas aos negros para ingresso no serviço público, cargos efetivos e empregos públicos na esfera federal, por meio de Editais de Concursos Públicos;

○ Lei $n^{\circ} 13.005$, de 25 de junho de 2014, que aprova o Plano Nacional de Educação (PNE 2014-2024);

○ Lei $n^{\circ}$ 12.711, de 9 de junho de 2014: Lei das cotas. Cria-se o sistema de cotas sociais nos processos seletivos de graduação para acesso ao ensino superior nas IFES;

- 02 Decretos:

○ Decreto $\mathrm{n}^{\mathrm{o}} 7.234$, de 19 de julho de 2010 - PNAES;

○ Decreto $n^{\circ} 7.824 / 2012$ - Regulamenta a Lei das Cotas (12.711/2012);

- 21 Informações de sítios da internet (a maioria de páginas oficiais de órgãos do governo);

- 255 Documentos da UnB:

○ 02 Regulamentos:

- Estatuto e Regulamento Geral da UnB, edição de 2011;

- Resolução: Resolução CEPE/UnB 91/2004;

○ 03 Relatórios:

- Relatório de Gestão 2009-2012;

- PDI 2011-2015;

- Relatório de Avaliação do Sistema de Cotas, 10 anos de experiência. Brasília/2013;

○ 05 Editais de Programas de Pós-graduação;

- Edital 01/2014 PPGSol/UnB: seleção de candidatos/as às vagas do programa de pós-graduação em sociologia para os cursos de mestrado acadêmico e doutorado para o primeiro período letivo de 2015;

- Edital 03/2014 PPGAS/UnB: seleção de candidatos residentes no Brasil às vagas do programa de pós-graduação em Antropologia 
social para o curso de mestrado acadêmico para o primeiro período letivo de 2015;

- Edital 04/2014 PPGAS/UnB: seleção de candidatos/as às vagas do programa de pós-graduação em Antropologia Social para o curso de doutorado para o primeiro período letivo de 2015;

- Edital 03/2015 PPGD/UnB: seleção de candidato (a)s às vagas do programa de pós-graduação em direito para os cursos de mestrado acadêmico e doutorado para o primeiro período letivo de 2016;

- Edital 01/2015 PPGDHC/UnB: Seleção de candidatos/as às vagas do Programa de pós-graduação em direitos humanos e cidadania Para o curso de mestrado acadêmico segundo período letivo de 2015;

- 245 Atas de reuniões da Câmara de Pesquisa e Pós-graduação, vinculada e presidida pelo decano de pesquisa e pós-graduação:

- 20 Atas de reuniões da CPP em $2004\left(n^{\circ}\right.$ de $682^{a}$ a $700^{a}$ e uma Ata Reunião Extraordinária);

- 20 Atas de reuniões da CPP em $2005\left(n^{\circ}\right.$ de $701^{a}$ a $719^{a}$ e uma Ata Reunião Extraordinária);

- 17 Atas de reuniões da CPP em $2006\left(n^{\circ}\right.$ de $720^{a}$ a 736 a $)$;

- 19 Atas de reuniões da CPP em 2007 (nº de 737 a 754 );

- 16 Atas de reuniões da CPP em $2008\left(n^{\circ}\right.$ de $755^{a}$ a $\left.770^{a}\right)$;

- 22 Atas de reuniões da CPP em $2009\left(n^{\circ}\right.$ de $771^{\text {a }}$ a $791^{a}$ e uma Ata Reunião Extraordinária);

- 30 Atas de reuniões da CPP em $2010\left(n^{\circ}\right.$ de $792^{a}$ a $811^{a}$ );

- 24 Atas de reuniões da CPP em $2011\left(n^{\circ}\right.$ de 812 a 835 $)$;

- 21 Atas de reuniões da CPP em $2012\left(n^{\circ}\right.$ de 836 a 856 ${ }^{a}$ );

- 21 Atas de reuniões da CPP em $2013\left(n^{\circ}\right.$ de $857^{a}$ a $868^{a}$, de $870^{a}$ a $876,878^{\mathrm{a}}$ e $\left.879^{\mathrm{a}}\right)$;

- 20 Atas de reuniões da CPP em 2014 (nº de 880a a 899ª);

- 15 Atas de reuniões da CPP em 2015 (nº de 900a a 914ª);

- 03 Documentos da UNEB:

○ Resolução n. ${ }^{\text {1 }}$ 196/2002;

○ Resolução n. ${ }^{\circ}$ 486/2002;

○ Resolução n. ${ }^{\circ}$ 710/2002; 
- 02 Documentos da UFRJ:

○ Edital 48 PPGAS/Museu/RJ: seleção de mestrado 2014;

○ Edital 49 PPGAS/Museu/RJ: seleção de mestrado 2014;

- 01 Documento da UFMG, o Relatório de Gestão do Exercício de 2011. Em 2012;

- 01 Documento da APG-UnB: Resolução I Fórum dos pós-graduandos da UnB em junho de 2015 .

Essa documentação foi sendo identificada, baseada na revisão da literatura acerca do tema, contendo a contextualização, o histórico, o marco legal e o seu aprofundamento na Universidade de Brasília.

\subsubsection{Entrevista semiestruturada}

Segundo Alyrio (2009, p. 206), quando se trata de pesquisa no campo da Ciência da Administração, "são poucas as situações que permitem a observação direta dos fatos. Assim, a maioria das informações são alcançadas diretamente das pessoas, por meio de entrevistas e questionários".

Para Hair et al (2005, p. 163), entrevista semiestruturada é uma abordagem na qual "o pesquisador fica livre para exercitar sua iniciativa no acompanhamento da resposta a uma pergunta", podendo "fazer perguntas relacionadas que não foram previamente imaginadas". Essa necessidade pode "resultar do surgimento de informações inesperadas e esclarecedoras, melhorando as descobertas". Esse tipo de entrevista tem "uma estrutura e orientação gerais, mas permite muita flexibilidade para incluir perguntas não estruturadas".

Para esta etapa, foi considerado o aspecto da possibilidade ao acesso ao local que interessa à investigação, para realização das entrevistas, segundo aconselham Sampieri et al (2006).

As entrevistas foram baseadas em um guia de assuntos e questões estruturais, nas 
quais "o entrevistador solicita ao indivíduo uma lista de itens em forma de conjunto ou categorias" (SAMPIERI et al, 2006, p. 381), com vistas à liberdade de se introduzir mais questões, a fim de se obter maior informação sobre o tema, como orientam os referidos autores.

Essa técnica foi empregada para se atingir prioritariamente os objetivos específicos: 3 - descrever as ações afirmativas adotadas na Universidade de Brasília para acesso de negros a cursos de pós-graduação stricto sensu no período de 2004 a 2015; 4 identificar as dificuldades ao acesso da população negra aos Programas de Pós-graduação stricto sensu ofertados pela Universidade de Brasília sob a perspectiva da instituição; 1 descrever o histórico das políticas públicas de educação superior que adotam ações afirmativas praticadas nas universidades públicas do Brasil; e 2 - descrever/caracterizar as boas práticas das políticas de ações afirmativas em programas de pós-graduação stricto sensu.

\subsubsection{Locus}

A Universidade de Brasília é uma Instituição Federal de Ensino Superior (IFES), que faz parte da administração indireta do Governo Federal, mantida por uma fundação pública de direito público com personalidade jurídica, denominada Fundação Universidade de Brasília, estabelecida pela Lei 3.998, de 15 de Dezembro de 1961, com sede na Capital Federal (Estatuto/UnB, 2011).

A estrutura organizacional da UnB está dividida entre: Conselhos Superiores; Reitoria; Unidades Acadêmicas; Órgãos Complementares; e, Centros. Nas unidades acadêmicas, encontram-se as atividades responsáveis pelas finalidades essenciais da Universidade de Brasília, que, segundo o artigo $3^{\circ}$ do Estatuto (AUTOR/ÓRGÃO, op.cit.), são o ensino, a pesquisa e a extensão. Elas são subdivididas em institutos e faculdades, cujas destinações foram definidas desde sua criação. Para os primeiros, fica a função de ensino e pesquisa, e para os segundos, a função de formação profissional (Lei 3.998/1961).

No contexto do tema da pesquisa, a universidade se posicionou como IFES de vanguarda, dando visibilidade e influenciando de forma positiva a consolidação do sistema de cotas para graduação. Em pós-gradação, ela acompanha a tendência de ampliação da prática, 
sendo uma das pioneiras, com quatro programas de pós-graduação que adotam reserva de vagas.

A UnB foi escolhida para a coleta de dados por ser referência no tema. Além disso, a acessibilidade e a viabilidade financeira também foram fatores que definiram a escolha da universidade.

\subsubsection{Seleção dos entrevistados}

Uma vez identificada a existência de quatro programas de pós-graduação stricto sensu com reservas de vagas para a população negra na UnB, fez-se a necessário o levantamento de informações de cunho tanto institucional quanto de iniciativas isoladas. Por isso, as entrevistas foram feitas envolvendo duas áreas estratégicas ligadas à Reitoria, primeira linha da estrutura organizacional da Universidade de Brasília, compreendidas como necessárias e interligadas para esse tipo de política ao acesso; e aos coordenadores dos cursos que implantaram a reserva de vagas em seus programas.

- Entrevistado 1: Diretor em exercício (2012-2016) da Diretoria de Pósgraduação (DIRPG), ligada à Administração Superior - Decanato de Pesquisa e Pós-graduação (DPP)

O DPP "é responsável pela formulação, coordenação e cumprimento do Plano de Desenvolvimento Institucional da Universidade de Brasília, no que tange à sua política de pós-graduação, pesquisa e desenvolvimento em todas as áreas de conhecimento" (UNB, 2015). Estão aqui inseridas as regras, as Políticas Públicas para a pós-graduação stricto sensu na universidade, de forma institucional.

A DIRPG, além de fazer o acompanhamento administrativo e acadêmico dos programas de pós-graduação da UnB, realiza estudos e propostas que auxiliam o DPP na formulação de políticas para apreciação na Câmara de Pesquisa e Pós-Graduação (CPP), e no Conselho de Ensino, Pesquisa e Extensão (CEPE). A DIRPG interage com as coordenações 
dos programas de pós-graduação, e com os órgãos financiadores e de avaliação da pósgraduação, além de participar da Comissão de Planejamento e Gerência do PROF/CAPES.

A DIRPG acompanha a regulamentação das atividades de ensino na pósgraduação, e o cumprimento da legislação interna e das agências de fomento que regulamentam a pós-Ggaduação na UnB, além de assessorar a CPP na emissão de pareceres de assuntos relacionados à sua esfera de competência.

É a área responsável pela implantação de uma possível política pública para os PPG's. Portanto, ao supor que a universidade pouco tem ser esforçado institucionalmente para atender às demandas por uma política pública de ação afirmativa que estimule a ampliação ao acesso da população negra aos cursos de pós-graduação stricto sensu, é necessário averiguar se essa suposição é confirmada. Uma forma é entrevistando os representantes das assossiações de pós-graduandos da UnB e os representantes discentes que participam dos colegiados da Universidade.A ausência do coleta dessas entrevistas se configura como limitação da pesquisa.

- Entrevistado 2: Decana em exercício (2012-2016) da Administração Superior Decanato de Assuntos Comunitários (DAC)

O DAC “está integrado ao Fórum de Pró-reitores de Assuntos Comunitários FONAPRACE, na defesa do acesso ao ensino público, gratuito e de qualidade, aliada a outras ações constantes que viabilizam a permanência do estudante na universidade, e colaboram efetivamente para sua formação" (UNB, 2015). Estão aqui ações de inclusão de diversidade social e permanência de estudantes socioeconomicamente desprivilegiados.

Entendendo, por meio da revisão teórica, que a população negra é também carente financeiramente, a associação de políticas de assistência estudantil para esse público alvo, com as ações afirmativas integradas ao DPP, é necessária. Portanto, é interessante para a pesquisa conhecer as ações ou planos desta área.

- Entrevistado 3: Coordenação do Programa de Pós-graduação Stricto Sensu em Sociologia 
- Entrevistado 4: Coordenação do Programa de Pós-graduação Stricto Sensu em Antropologia

Os departamentos de Antropologia e Sociologia fazem parte da unidade acadêmica Instituto de Ciências Sociais (ICS) da Universidade de Brasília. Esses departamentos são responsáveis pelo PPG's em Antropologia e Sociologia, respectivamente. Ambos aprovaram, em 2014, a reserva de vagas, com turma em andamento em 2015. Portanto, entender a motivação das iniciativas e a integração com o DPP nessas entrevistas são de suma importância.

- Entrevistado 5: Coordenação do Programa de Pós-graduação Stricto Sensu em Direito

A Faculdade de Direito oferta o PPG em Direito, tendo aprovado o sistema de reserva de vagas em 2015, com editais de seleção para início em 2016 já publicados. Trata-se de um dos quatro que passaram a adotar reserva de vagas para a população negra.

- Entrevistado 6: Coordenação do Programa de Pós-graduação Stricto Sensu em Direitos Humanos

Esse PPG está sob a responsabilidade do Centro de Estudos Avançados Multidisciplinares (CEAM), e coloca a UnB entre as poucas que oferecem pós-graduação stricto sensu em Direitos Humanos e Cidadania, tendo implantado a reserva de vagas para o público negro a partir de 2015.

\subsubsection{Roteiro das entrevistas}

Os dados coletados e o conhecimento adquirido por meio da pesquisa bibliográfica e documental contribuíram para a elaboração das questões da entrevista, com base na orientação de Alyrio (2009). 
As perguntas foram elaboradas, baseadas no Quadro 02, de forma a interliga-las ao objetivo da pesquisa - cujo alcance pretende-se chegar por intermédio dos objetivos específicos - às dimensões e às categorias.

\begin{tabular}{|c|c|c|c|c|c|c|}
\hline \multirow[b]{2}{*}{ Dimensão } & \multirow[b]{2}{*}{$\begin{array}{c}\text { Categoria } \\
\text { Teórica }\end{array}$} & \multirow{2}{*}{\multicolumn{2}{|c|}{ Objetivo Específico }} & \multicolumn{2}{|c|}{ Perguntas } & \multirow[b]{2}{*}{ Base Teórica } \\
\hline & & & & $\frac{\tilde{8}}{0}$ & ֻै & \\
\hline \multirow[t]{2}{*}{ Histórico } & $\begin{array}{l}\text { Políticas } \\
\text { Públicas }\end{array}$ & 1) & $\begin{array}{l}\text { Descrever o histórico das } \\
\text { políticas públicas de } \\
\text { educação superior que } \\
\text { adotam ações afirmativas } \\
\text { praticadas nas universidades } \\
\text { públicas do Brasil; }\end{array}$ & $\begin{array}{l}1 \mathrm{e} \\
2\end{array}$ & $\begin{array}{l}1,2 \\
10,12 \\
\text { e } 14\end{array}$ & $\begin{array}{l}\text { Contins e Sant'ana (1996); } \\
\text { Carvalho (2006); Contins e } \\
\text { Sant'ana (1996); Peixoto e Braga } \\
\text { (2012); Santos et al (2008); Rua } \\
\text { (1998), Barreto (2007); } \\
\text { Trevisan et al (2013) }\end{array}$ \\
\hline & $\begin{array}{c}\text { Boas } \\
\text { Práticas }\end{array}$ & 2) & $\begin{array}{l}\text { Descrever/caracterizar as } \\
\text { boas práticas das políticas de } \\
\text { ações afirmativas em } \\
\text { Programas de Pós-graduação } \\
\text { stricto sensu; }\end{array}$ & $\begin{array}{l}10 \\
11 \mathrm{e} \\
12\end{array}$ & 15 & $\begin{array}{l}\text { Carvalho (2006); Contins e } \\
\text { Sant'ana (1996); Peixoto e Braga } \\
\text { (2012); Santos et al (2008); }\end{array}$ \\
\hline \multirow{2}{*}{$\begin{array}{c}\text { Ações } \\
\text { Afirmativas }\end{array}$} & $\begin{array}{c}\text { Ações } \\
\text { Afirmativas }\end{array}$ & 3) & $\begin{array}{l}\text { Descrever as ações } \\
\text { afirmativas adotadas na } \\
\text { Universidade de Brasília para } \\
\text { acesso de negros em cursos } \\
\text { de pós-graduação stricto } \\
\text { sensu, no período de } 2004 \text { a } \\
2015 ;\end{array}$ & 3 e 4 & $\begin{array}{l}3,4,9 \\
11, \mathrm{e} \\
13\end{array}$ & $\begin{array}{l}\text { Contins e Sant'ana (1996); } \\
\text { Carvalho (2006); Contins e } \\
\text { Sant'ana (1996); Peixoto e Braga } \\
\text { (2012); Santos et al (2008); Rua } \\
\text { (1998); Barreto (2007); SPM } \\
\text { (2011) }\end{array}$ \\
\hline & Acesso & 4)) & $\begin{array}{l}\text { Identificar as dificuldades ao } \\
\text { acesso da população negra } \\
\text { aos Programas de Pós- } \\
\text { graduação stricto sensu } \\
\text { ofertados pela Universidade } \\
\text { de Brasília sob a perspectiva } \\
\text { da instituição. }\end{array}$ & $\begin{array}{l}5,6 \\
7,8 \mathrm{e} \\
9\end{array}$ & $\begin{array}{l}5,6,7 \\
\text { e } 8\end{array}$ & $\begin{array}{l}\text { Contins e Sant'ana (1996); } \\
\text { Carvalho (2006); Contins e } \\
\text { Sant'ana (1996); Peixoto e Braga } \\
\text { (2012); Santos et al (2008); } \\
\text { Velloso (2011). Barreto (2007) }\end{array}$ \\
\hline
\end{tabular}

Fonte: Elaborado com dados da pesquisa.

\section{- Perguntas do Bloco 1: Instituição}

O primeiro bloco refere-se às perguntas feitas para os representantes do DPP e do

DAC buscando a visão da Universidade enquanto instituição:

1. Entre 2004 a 2015 a UnB pensou em alguma política pública de forma institucional para incentivar o acesso da população negra aos programas de pósgraduação stricto sensu na UnB? 
2. Quais setores da UnB você avalia que devem estar integrados para implantação de uma política institucional eficiente?

3. Quais as ações afirmativas - ligadas ou não a alguma política pública - este decanato realizou para ampliar o acesso de negros aos cursos de Pós-graduação stricto sensu, entre os anos de 2004 a 2015?

4. Quais as dificuldades institucionais para desenhar e implantar uma ação de ampliação ao acesso à população negra aos Programas de Pós-graduação stricto sensu?

5. Este decanato já realizou algum estudo sobre a ampliação ao acesso da população negra aos PPG's stricto sensu?

6. Quais mudanças institucionais você considera que são importantes para que ocorra a ampliação ao acesso da população negra nos PPG's?

7. Quais as dificuldades encontradas, do ponto de vista da população negra, para que ela acesse os programas de pós-graduação stricto sensu?

8. Como você avalia a atuação deste decanato na ampliação ao acesso da população negra nos PPG's?

9. Quais são os desafios para a ampliação ao acesso da população negra aos PPG's?

10. Você conhece experiências dessas políticas em outras universidades públicas?

11. Você conhece o modelo adotado na Universidade Estadual da Bahia, que implantou ações afirmativas para todos os cursos e graus desde 2004? Como você avalia essa ação afirmativa?

12. Como este decanato vê a iniciativa do Departamento de Sociologia, que aprovou em 2013, e implantou em 2015, via Edital 1/2015, a ação afirmativa que reserva $20 \%$ de suas vagas do mestrado e doutorado?

\section{- Perguntas do Bloco 2: Unidades Acadêmicas}


Essas perguntas foram feitas para o Coordenador em exercício do Programa de Pós-graduação Stricto Sensu do Departamento de Sociologia, buscando a visão de unidade acadêmica.

1. A Sociologia foi o primeiro curso a implantar a reserva de vagas para negros na $\mathrm{UnB}$ ?

2. Como foi a iniciativa do curso para incluir reserva de vaga?

3. Vocês tiveram dificuldade para implantar esse curso?

4. Na seleção, o público universal teve resultado melhor do que os negros?

5. Vocês consideram a reserva de vagas um estímulo para o acesso a negros de fato?

6. Vocês observam que os próprios negros têm preconceito, inibindo, com isso, a busca pela reserva de vagas (identificação)?

7. Dos estudantes que ingressaram, existem egressos do sistema de cotas da UnB?

8. Você concorda que os cursos mais técnicos, sem concorrência, não precisam de ações afirmativas?

9. Você acha que uma política pública, se implantada de forma institucional, como ocorreu com a graduação, estimularia de forma mais eficiente o público negro?

10. Tem mais alguma área que poderia ser envolvida, de forma institucional, como apoiadora dos programas?

11. Tem algum desafio para continuar com a política?

12. Vocês sabem como a CAPES vê essa iniciativa, ou não tem nenhuma visibilidade?

13. Como que foi a influência do movimento estudantil para a iniciativa da criação dessa reserva de vagas no programa?

14. Qual modelo você acha ideal de reserva de vaga, de ação afirmativa para pósGraduação?

15. Qual o modelo da ação afirmativa do PPSOL? 


\subsection{TÉCNICAS DE ANÁLISES DE DADOS}

Para Sampieri et al (2006), a análise de dados em pesquisas qualitativas não é algo definitivo, uma vez que é estabelecido um plano geral que pode ser modificado em função dos resultados, requerendo, assim, flexibilidade. No entanto, sua finalidade deve ser perseguida, qual seja: "alcançar os objetivos de pesquisa e responder às questões do estudo para gerar conhecimento" (SAMPIERI et al, 2006, p. 505).

$\mathrm{Na}$ fase de formulação da pesquisa, foram realizadas leituras de artigos científicos sobre o tema, para levantar o conhecimento e propor uma abordagem que agregasse, e que não fosse repetitiva frente ao conhecimento acumulado. Com base nessas leituras, foi possível estabelecer toda a construção da Dissertação, somado aos livros consultados sobre metodologia de pesquisa científica.

Antecedendo à aplicação das técnicas, foi realizada uma análise, com intuito de sistematizar o material coletado. Durante o processo de análise, os dados foram sistematicamente revidados, tanto na análise documental quanto nas entrevistas. A intenção foi primar pela combinação de conteúdo, validade e autenticidade, conservando, assim, o rigor do estudo como alerta Grawitz (1975).

Posto isso, as técnicas aplicadas foram: Análise Documental e Análise de Conteúdo. A primeira buscou atingir prioritariamente os objetivos específicos 1 e 2 , enquanto que a segunda procurou alcançar, prioritariamente, os objetivos específicos 3 e 4 . Ambas serão detalhadas na sequência.

\subsubsection{Análise documental}

Ao longo da leitura da literatura, foram sendo identificados os documentos relacionados ao tema estudado. A análise dos documentos foi feita utilizando-se a técnica Análise Documental, considerada por Grawitz (1975), como um método. A autora alerta para três aspectos a serem considerados para certificar a rigidez do método: a autenticidade do 
texto e a identificação do autor; a validade da interpretação; e a veracidade do fato.

O material consultado mostra uma evolução de como o governo brasileiro, por meio da legislação, documentos e sítios oficiais, vem evoluindo acerca da busca pela justiça racial, o que envolve desde a questão mais abrangente do reconhecimento da discriminação no âmbito social até políticas públicas de ação afirmativa no Ensino Superior, foco deste estudo. Documentos e relatórios da Universidade de Brasília e as informações obtidas em sítios, a maioria páginas oficiais do governo, também contribuíram para o levantamento do histórico das políticas públicas de ação afirmativa no Ensino Superior brasileiro, incluindo-se aí a UnB.

É importante esclarecer que os documentos foram selecionados de forma a conferir a autenticidade do texto e a identificação do autor, a validade da interpretação, e, a veracidade do fato relatado, preservando, assim, o rigor científico, como sugere Grawitz (op.cit.). Abaixo encontra-se o quadro com a contribuição da análise documental para a pesquisa.

Quadro 3 - Análise Documental e Sua Contribuição

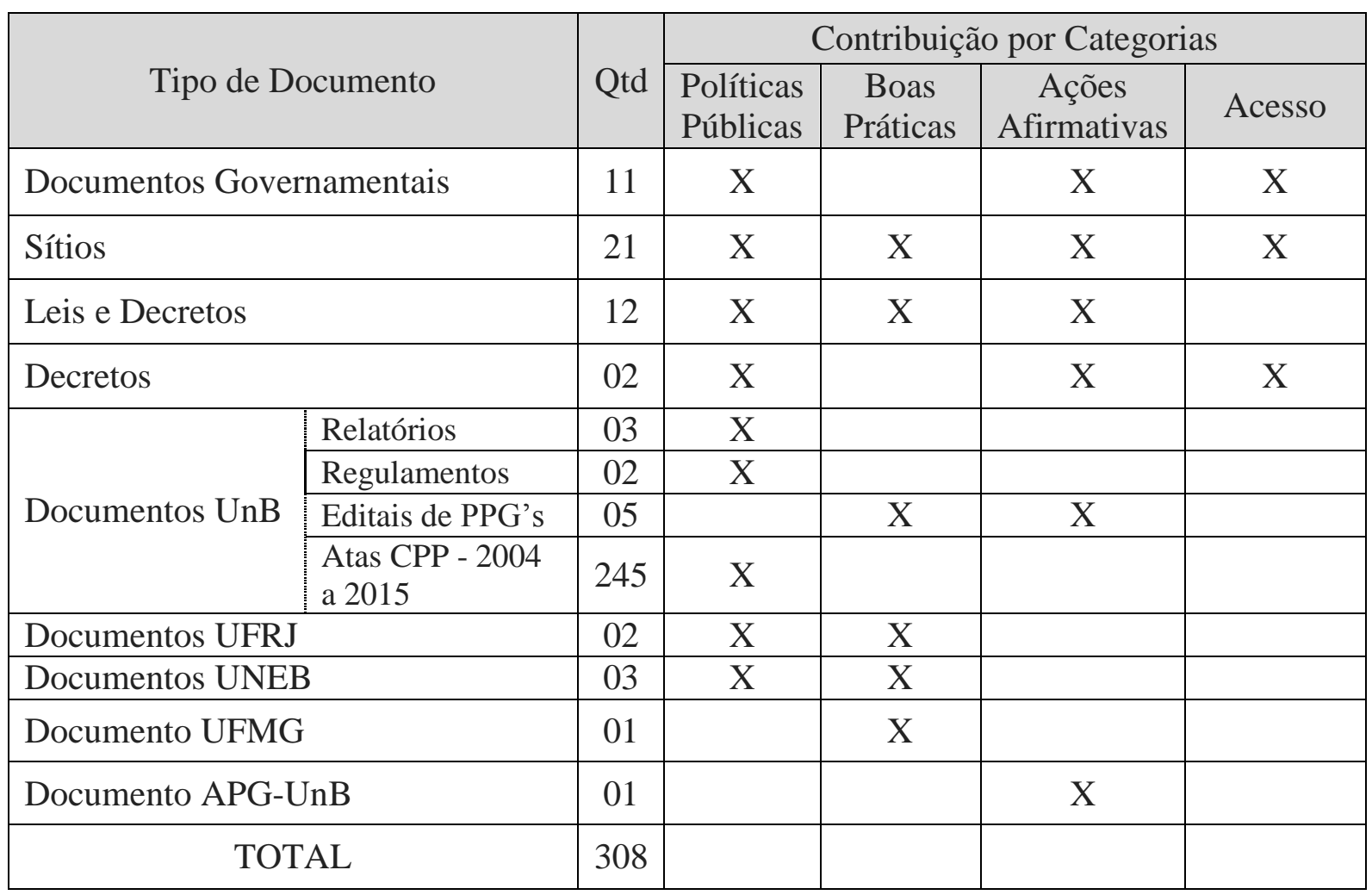

Fonte: Elaboração própria 


\subsubsection{Entrevistas semiestruturadas}

Foram realizadas entrevistas baseadas em um guia de assuntos e questões de estrutura ou estruturais nas quais "o entrevistador solicita ao indivíduo uma lista de itens em forma de conjunto ou categorias" (SAMPIERI et al, 2006, p. 381), com vistas a se ter liberdade para introduzir mais questões, a fim de obter maior informação sobre o tema, como orientam os referidos autores.

Os participantes selecionados são profissionais direta e indiretamente envolvidos com os programas de pós-graduação stricto sensu na Universidade de Brasília. Nesse sentido, as entrevistas foram separadas em dois blocos a fim de ter a percepção das áreas responsáveis por implantar uma política de ação afirmativa de forma institucional e integrada na UnB - a Diretoria de Pós-graduação (DIRPG) e o Decanato de Assuntos Comunitários (DAC), e, pelas unidades acadêmicas as quais implantaram tal política de forma isolada na UnB, a saber: Instituto de Ciências Sociais (ICS), que engloba os cursos Antropologia e Sociologia; Faculdade de Direito (FD), com o programa em Direito, e o Centro de Estudos Avançados Multidisciplinares (CEAM), com o programa em Direitos Humanos e Cidadania.

A intenção foi entrevistar o(a) coordenador(a) dos quatro cursos com reserva de vagas em seus Programas de Pós-graduação stricto sensu, porém, por incompatibilidade de agenda, e com limitação de tempo, não foi possível entrevistar os coordenadores da Antropologia/ISC, do Direito e do Direitos Humanos e Cidadania/CDS. A amostra reduzida constituiu uma limitação da pesquisa. Todavia, o depoimento do coordenador em exercício do Programa de Pós-graduação em Sociologia (PPGSOL/ISC) se mostrou representativo, com relevante contribuição ao estudo, pela propriedade com que falou sobre o assunto, e pelo conhecimento no campo em que está inserido o tema proposto. Inclusive, vale informar que o coordenador responsável pela aprovação da reserva de vagas para o PPGSOL foi o anterior ao atual que está em exercício. Os entrevistados, no final, foram:

- Entrevistado 1 (E1): diretor representante de Pós-graduação (DIRPG) em exercício (2012-2016), ligado ao Decanato de Pesquisa e Pós-graduação (DPP).

- Entrevistado 2 (E2): decana representante de assuntos comunitários em exercício (2012-2016), do Decanato de Assuntos Comunitários (DAC). 
- Entrevistado 3 (E3): coordenador em exercício do programa de pós-graduação stricto sensu em Sociologia, do Instituto de Ciências Sociais (ICS).

As entrevistas foram gravadas com prévia autorização dos entrevistados - os quais assinaram o Termo de Consentimento Livre e Esclarecido do/a Participante da Pesquisa - demonstrando respeito a ética em pesquisa. As entrevistas foram degravadas, a fim de possibilitar a realização da análise. As entrevistas foram realizadas nos locais de trabalho dos decanos e do coordenador entrevistados. No total, foram somadas uma hora, quarenta e oito minutos e vinte o oito segundos de gravação. Abaixo, encontra-se o quadro panorama da realização das entrevistas semiestruturadas.

Quadro 4 - Panorama das Entrevistas Semiestruturadas

\begin{tabular}{|c|c|c|l|c|c|}
\hline Entrevistado & Código & Data & \multicolumn{1}{|c|}{ Local } & Duração & Transcrição \\
\hline Entrevistado 1 & E1 & $04 / 09 / 2015$ & $\begin{array}{l}\text { UnB, Campus Darcy } \\
\text { Ribeiro, Decanato de Pós- } \\
\text { graduação e Pesquisa. }\end{array}$ & 00.36 .15 & 17 páginas \\
\hline Entrevistado 2 & E2 & $05 / 10 / 2015$ & $\begin{array}{l}\text { UnB, Campus Darcy } \\
\text { Ribeiro, Decanato de } \\
\text { Assuntos Comunitários. }\end{array}$ & 00.15 .54 & 6 páginas \\
\hline Entrevistado 3 & E3 & $02 / 10 / 2015$ & $\begin{array}{l}\text { UnB, Campus Darcy } \\
\text { Ribeiro, Departamento de } \\
\text { Sociologia. }\end{array}$ & 00.49 .59 & 16 páginas \\
\hline Entrevistado 4 & E4 & - & - & 0 & 0 \\
\hline Entrevistado 5 & E5 & - & - & 0 & 0 \\
\hline Entrevistado 6 & E6 & - & - & 0 & 0 \\
\hline \multicolumn{7}{|c|}{ TOTAIS } & -1.48 .28 & 34 páginas \\
\hline
\end{tabular}

Fonte: Elaborado com dados da pesquisa (2015)

\subsubsection{Princípios da Análise de Conteúdo}

Para operacionalização deste estudo, foram utilizados os princípios de análise de conteúdo apresentados por Bardin (2007) e por Grawitz (1975). Os autores consultados foram Bardin (2004), principalmente pela abordagem aprofundada, Grawits (1975) e Sumpieri et al, (2006). Além disso, foi priorizada a função heurística, na qual, por meio da análise de conteúdo, "enriquece a tentativa exploratória, aumenta a propensão à descoberta" (BARDIN, op.cit., p. 25). 
Segundo Sampieri et al (2006, p. 494), “(:) na maioria dos estudos qualitativos codificam-se os dados para se ter uma descrição mais completa, resumi-los, eliminar informação irrelevante e gerar maior sentido de entendimento do material analisado". Grawitz (1975) afirma que a primeira etapa da pesquisa é saber o que se busca, o objetivo, e as respostas podem estar nas perguntas feitas por meio de entrevistas ou questionários, ou em análise de documentos, técnica na qual se faz recortes dos dados dos documentos baseados nas categorias.

Segundo Bardin (2004), este método é considerado muito empírico, tem relação com o tipo de fala e de interpretação pretendida como objetivo. Inexiste uma receita pronta e sim algumas regras de base às quais são dificilmente aplicáveis em alguns casos, mas que precisam ser seguidas e precisam ser claras e precisas o suficiente para permitir a compreensão de pesquisadores do mesmo tema, diz Grawitz (1975). A técnica "adequada ao domínio e ao objetivo pretendidos tem que ser reinventada a cada momento..." (BARDIN, op.cit., p. 26).

A Análise de conteúdo é definida como "um conjunto de técnicas de análise das comunicações". Trata-se da reunião de instrumentos que se adaptam ao seu campo de atuação, considerado amplo, que são "as comunicações", segundo Bardin (op.cit., p. 27). Segundo Henry e Moscovici (1968) apud Bardin (op.cit.), tudo o que é dito ou escrito é suscetível a uma análise de conteúdo.

Em uma fase inicial, Bardin (2004, p. 29) sugere fazer um quadro esquemático contendo o conjunto dos tipos de comunicações segundo os critérios de "número de pessoas envolvidas na comunicação" e "a natureza do código e do suporte". Abaixo, está o que foi determinado para este estudo segundo o quadro proposto. 
Quadro 5 - Domínios Possíveis da Aplicação da Análise de Conteúdo

\begin{tabular}{|c|c|c|c|}
\hline \multirow{2}{*}{$\begin{array}{l}\text { Código e } \\
\text { suporte }\end{array}$} & \multicolumn{3}{|c|}{ Número de pessoas implicadas na comunicação } \\
\hline & Comunicação dual Diálogo & Grupo restrito & Comunicação de massa \\
\hline & & $\begin{array}{l}\text { Comunicações escritas } \\
\text { trocadas dentro de um grupo }\end{array}$ & $\begin{array}{c}\text { Textos jurídicos; } \\
\text { Informações de sítios }\end{array}$ \\
\hline 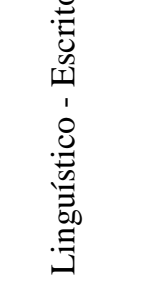 & & $\begin{array}{l}\text { 1) Editais de PPG's da UnB; } \\
\text { 2) Relatórios das } \\
\text { Universidades; }\end{array}$ & $\begin{array}{l}\text { 1) Leis; } \\
\text { 2) Documentos } \\
\text { governamentais; } \\
\text { 3) Informações de sítios } \\
\text { oficiais de órgãos } \\
\text { públicos }\end{array}$ \\
\hline & Entrevistas & & \\
\hline 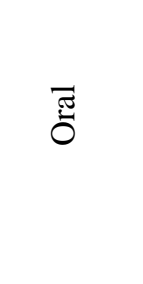 & $\begin{array}{l}\text { 1) Diretor de Pós-graduação da UnB } \\
\text { em exercício (2012-2016); } \\
\text { 2) Decana de Assuntos Comunitários, } \\
\text { em exercício (2012-2016); } \\
\text { 3) Coordenador do Programa de Pós- } \\
\text { graduação em Sociologia em } \\
\text { exercício (2012-2016) }\end{array}$ & & \\
\hline
\end{tabular}

Fonte: Elaboração própria, baseado no quadro "Domínios possíveis da aplicação da análise de conteúdo" proposto por Bardin (2004, p. 30)

Em um segundo nível, em que se faz a descrição analítica, "tratamento da informação contida nas mensagens”, segundo Bardin (2004, p. 29), as categorias foram definidas (iniciais, intermediárias e finais) e as unidades de registro foram bem delimitadas neste estudo. Ambas as classificações foram feitas a partir das categorias teóricas definidas ex-ante.

Para Grawitz (1975), as categorias são expressões que resumem o sentido do que se está agrupando, e sua definição faz parte de uma primeira etapa da análise de conteúdo. No presente estudo, as categorias foram eleitas ex-ante a coleta de dados. Para isso, realizou-se a releitura do material literário e documental, para certificação do que era essencial com relação ao seu objetivo.

Essencialmente foi aplicado:

Este tipo de análise, o mais generalizado e transmitido, foi cronologicamente o primeiro, podendo ser denominado análise categorial. Esta pretende tomar em consideração a totalidade de um texto, passando-o pelo crivo da classificação e do recenseamento, segundo a frequência de presença (ou de ausência) de itens de sentido. Isso pode constituir um primeiro passo, obedecendo ao princípio de objetividade e racionalizando através de número e percentagem uma interpretação que, sem ela, teria de ser sujeita a aval. É o método das categorias, espécie de gavetas ou rubricas significativas que permitem a classificação dos elementos de significação constitutivos da mensagem. É, portanto, um método taxonômico bem 
concebido para satisfazer os colecionadores preocupados em introduzir uma ordem, segundo certos critérios, na desordem aparente (BARDIN, 2004, p. 32).

A transcrição das unidades de contexto (falas) que formaram as categorias iniciais está no quadro analítico disposto como apêndice, com o título 'Sistema de Categorização (Analítico)'. O quadro 6, 'Sistema de Categorização (Sintético)', representa o sistema de classificação elaborado a partir das entrevistas.

Quadro 6 - Sistema de Categorização (Sintético)

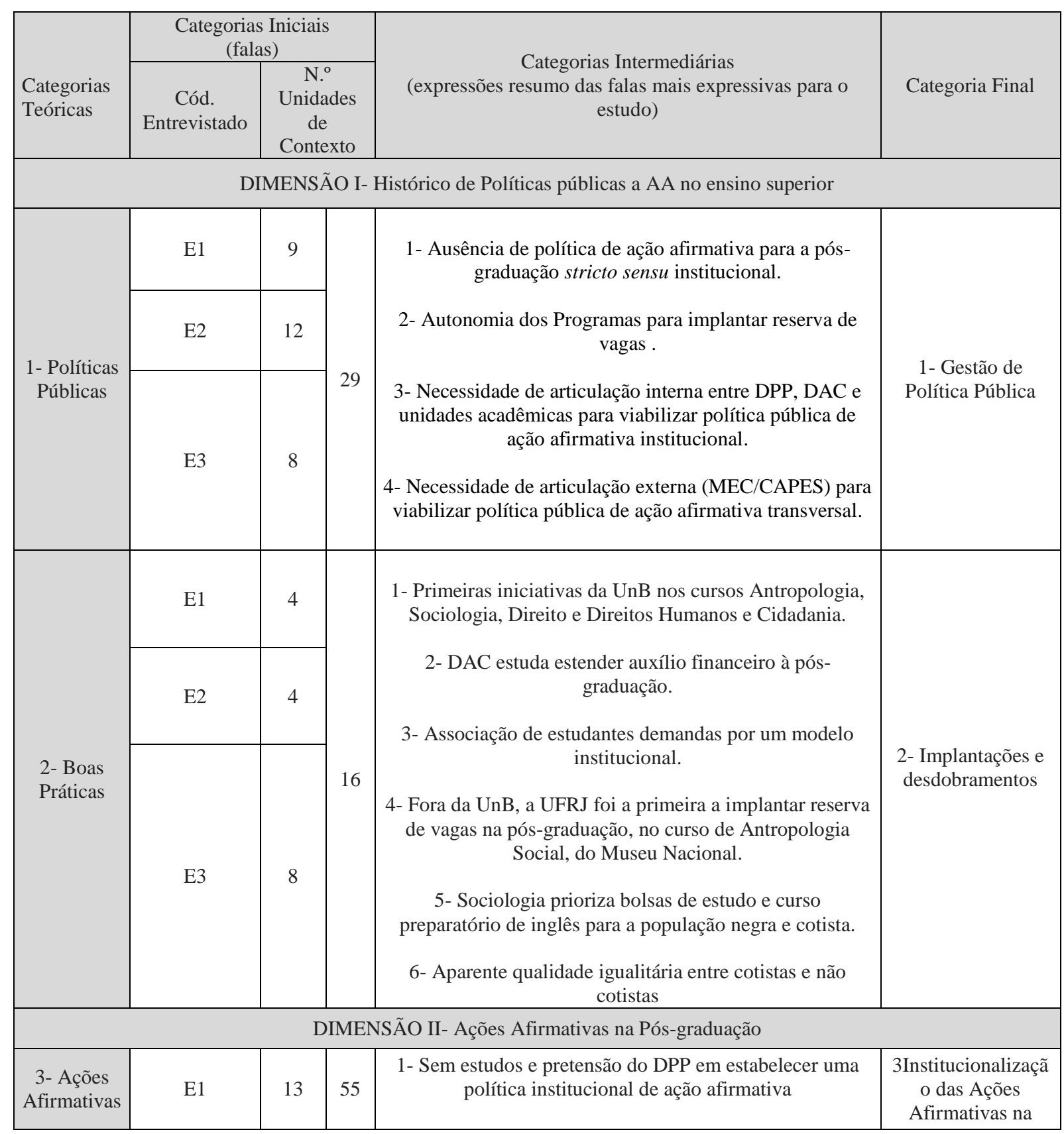




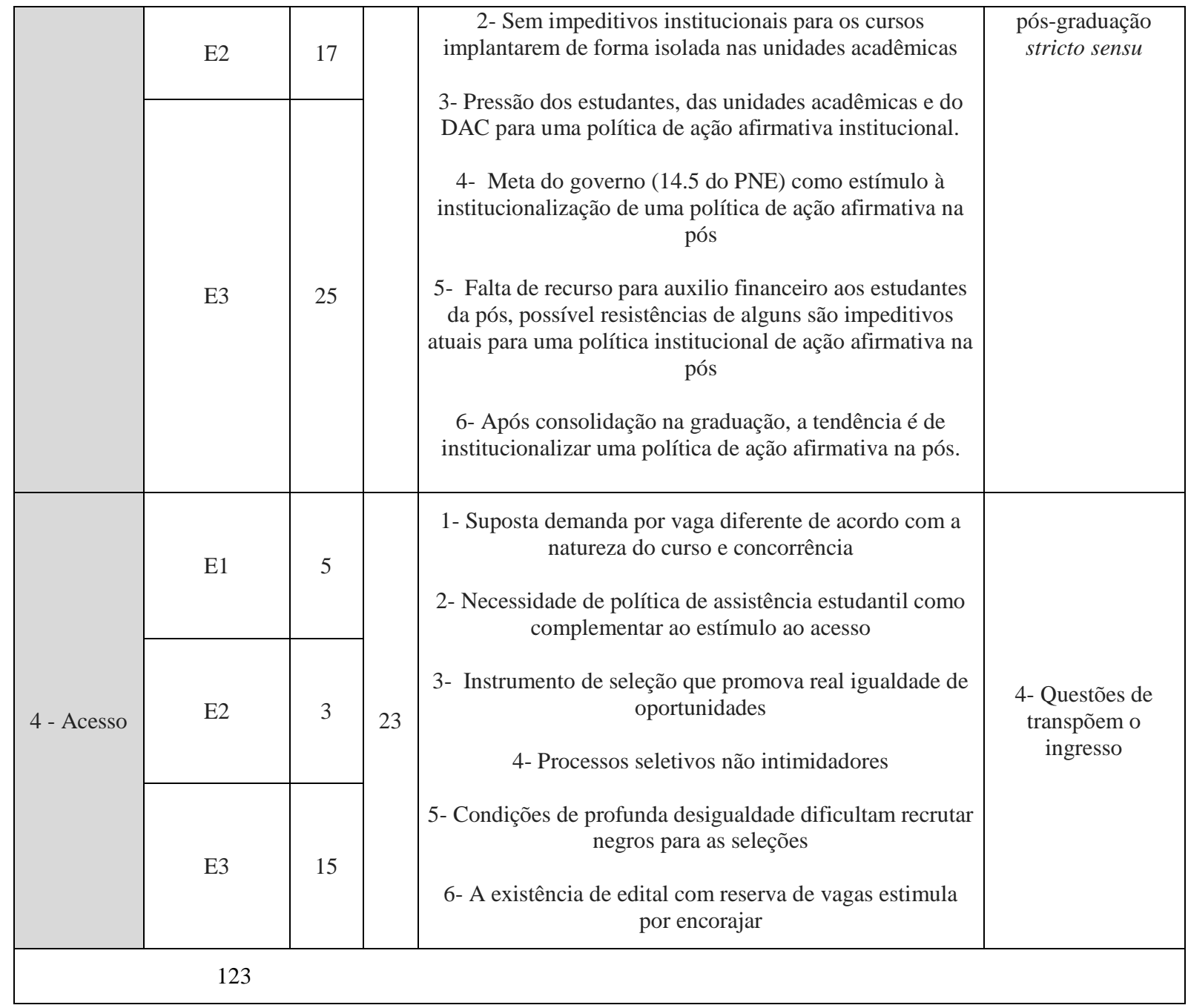

Fonte: Elaboração própria.

Foi feita uma codificação, a fim de sistematizar a utilização das informações fruto da análise de conteúdo dos quadros codificação do sistema de categorização, sintético e analítico. A intenção é facilitar o entendimento no discorrer dos resultados.

Quadro 7 - Codificação do Sistema de Categorização

\begin{tabular}{|l|l|c|}
\hline \multicolumn{2}{|l|}{ Descrição } & Código \\
\hline \multirow{3}{*}{ Dimensão } & Histórico & I \\
\cline { 2 - 3 } & Ações Afirmativas & II \\
\hline \multirow{4}{*}{ Categorias Teóricas } & Política Pública & 1 \\
\cline { 2 - 3 } & Boas Práticas & 2 \\
\cline { 2 - 3 } & Ações Afirmativas & 3 \\
\cline { 2 - 3 } & Acesso & 4 \\
\hline \multirow{3}{*}{ Entrevistados } & Entrevistado 1 & E1 \\
\cline { 2 - 3 } & Entrevistado 2 & E3 \\
\cline { 2 - 3 } & Entrevistado 3 & \\
\hline
\end{tabular}




\begin{tabular}{|l|l|c|}
\hline Categorias Iniciais & Números arábicos por fala & de 1 a 25 \\
\hline Categorias Intermediárias & Números arábicos por expressão & de 1 a 25 \\
\hline \multirow{5}{*}{ Categorias Finais } & Gestão de Política Pública & 1 \\
\cline { 2 - 3 } & Implantações e desdobramentos & 2 \\
\cline { 2 - 3 } & Institucionalização & 3 \\
\cline { 2 - 3 } & $\begin{array}{l}\text { Questões que transpõem o } \\
\text { ingresso }\end{array}$ & 4 \\
\hline & Fonte: Elaboração própria.
\end{tabular}

\subsubsection{Interpretação dos dados}

Para Grawitz (1975), a fase de análise e interpretação dos resultados é delicada e exige habilidade do pesquisador de ponderar entre o rigor científico e a intuição. É o momento de conciliar o conhecimento adquirido sobre o tema e sobre o processo de pesquisa.

No sistema de categoria, foi levada em consideração a relação entre as categorias teóricas (originadas a partir dos objetivos específicos); as falas dos entrevistados (unidades de contexto), expostas como categorias iniciais; as categorias intermediárias que resumem em expressões das falas mais relevantes; e as categorias finais as quais sintetizam todo esse caminho. A lógica do sistema de classificação é a codificação preconizada por Bardin (2004, p. 97), como sendo necessária para se saber a razão "por que e como analisar", para se saber explicar. É a transformação que permite chegar a uma 'representação do conteúdo'.

A seguir, apresenta-se a explicação de cada elemento de classificação, segundo Bardin (2004).

\section{- Unidades de registro ou contexto}

Segundo Grawitz (1975), na codificação das respostas de entrevistas pode ser utilizada unidade de contexto. Como havia um número limitado de entrevistas, não fazia sentido usar recortes em nível linguístico (ex: palavra, frase), sendo mais pertinente adotar o recorte semântico (ex: contexto, tema), portanto, utilizou-se a unidade de contexto, que são as falas dos entrevistados. 


\section{- Regra de contagem}

Foi utilizada, também, a regra de contagem de unidade de registro por contexto, subdividindo-se também por entrevistado consultado, ou seja, a frequência que determinado entrevistado abordou o contexto. Por fim, somou-se, foi agrupado, por categorias detalhadas na sequência.

\section{- Categorias Finais}

O tema central que permeia todas as categorias é caracterizado por 'ações afirmativas ao acesso da população negra aos programas de pós-graduação (PPG's) stricto sensu, com aprofundamento na Universidade de Brasília'. Algumas subcategorias foram criadas para facilitar a identificação da essência das categorias. Esse passo teve a intenção de minimizar as limitações da aplicação da análise de conteúdo em pesquisas qualitativas relacionadas à interpretação do pesquisador, Bardin (2004). As categorias finais foram definidas após um processo de análise das falas das entrevistas de forma sistematizada, e por subcategorias. As dimensões e as categorias teóricas foram a referência para a análise dos significados das falas (unidades de contextos), compondo as categorias iniciais. Baseado nisso, buscaram-se as falas ou expressões mais representativas para definição das categorias intermediárias. Por fim, buscou-se sintetizar toda significação nas categorias finais.

O quadro 8, disponível abaixo, 'Sistema de Categorização (Analítico)', exibe o resultado desse processo de análise de conteúdo:

Quadro 8 - Sistema de Categorização (Analítico)

\begin{tabular}{|c|c|c|c|c|c|}
\hline 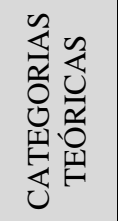 & c & & CATEGORIAS INICIAIS & $\begin{array}{l}\text { CATEGORIAS } \\
\text { INTERMEDIÁRIAS }\end{array}$ & $\begin{array}{l}\text { CATEGORIAS } \\
\text { FINAIS }\end{array}$ \\
\hline \multicolumn{6}{|c|}{ DIMENTSÃO I - Histórico de Políticas Públicas de Ações Afirmativas no Ensino Superior } \\
\hline \multirow{3}{*}{ 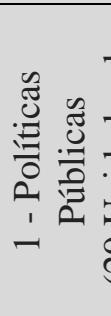 } & \multirow{3}{*}{ E1 } & 1 & $\begin{array}{l}\text { O programa de pós-graduação na Universidade de } \\
\text { Brasília é organizado pelo decanato de pesquisa e } \\
\text { pós-graduação. }\end{array}$ & \multirow{3}{*}{$\begin{array}{l}\text { 1- Ausência de política de } \\
\text { ação afirmativa } \\
\text { institucional para a pós } \\
\text { (pelo DPP) }\end{array}$} & \multirow{3}{*}{$\begin{array}{l}\text { 1- Gestão de Política } \\
\text { Pública }\end{array}$} \\
\hline & & 2 & $\begin{array}{l}\text { As decisões do decanato não são decisões de um } \\
\text { diretor ou de um decano, mas de um colegiado. }\end{array}$ & & \\
\hline & & 3 & $\begin{array}{l}\text { Cada programa tem que ter um colegiado. Então, } \\
\text { cada programa foi criado, na verdade, por iniciativa } \\
\text { de um grupo de professores. }\end{array}$ & & \\
\hline
\end{tabular}




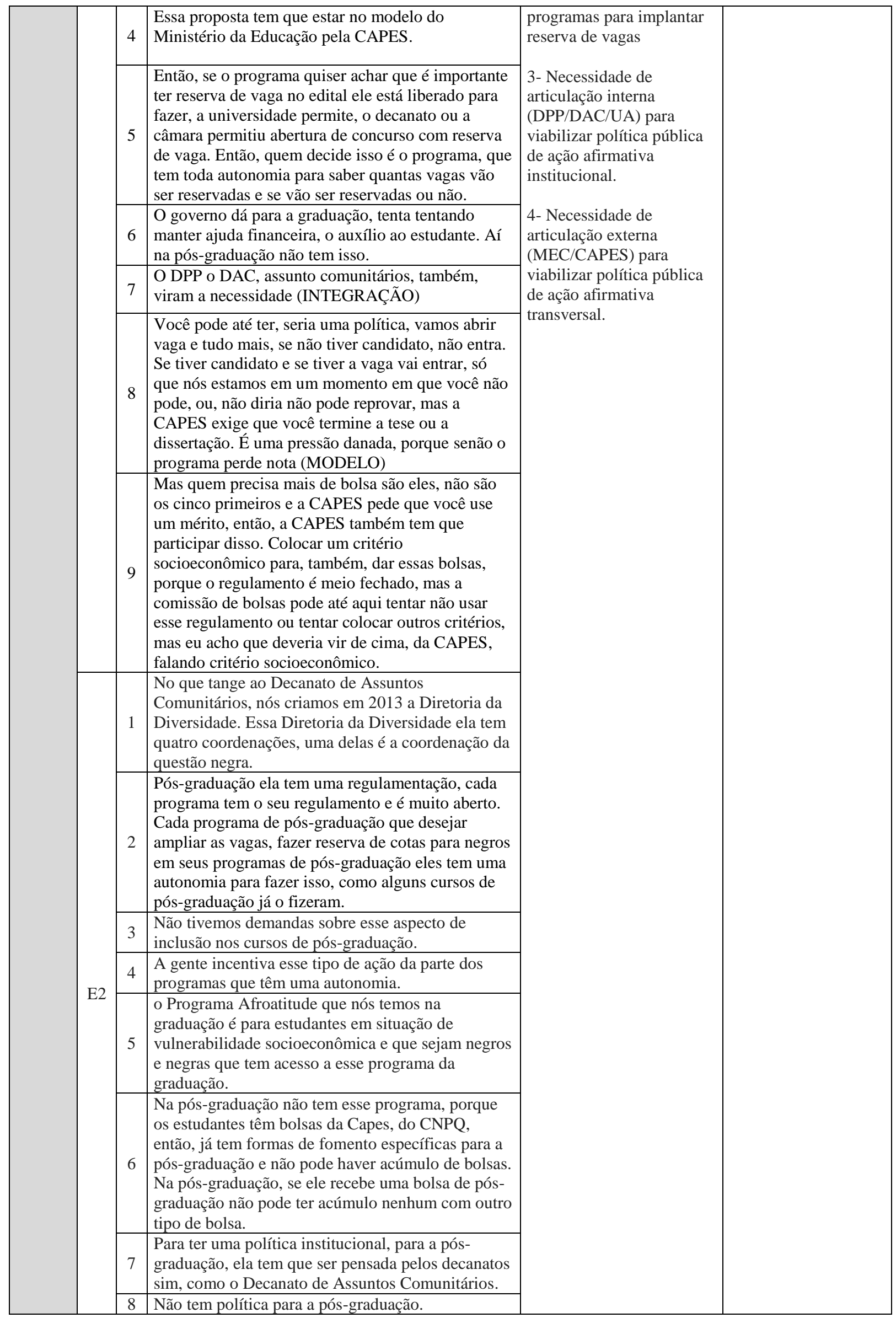




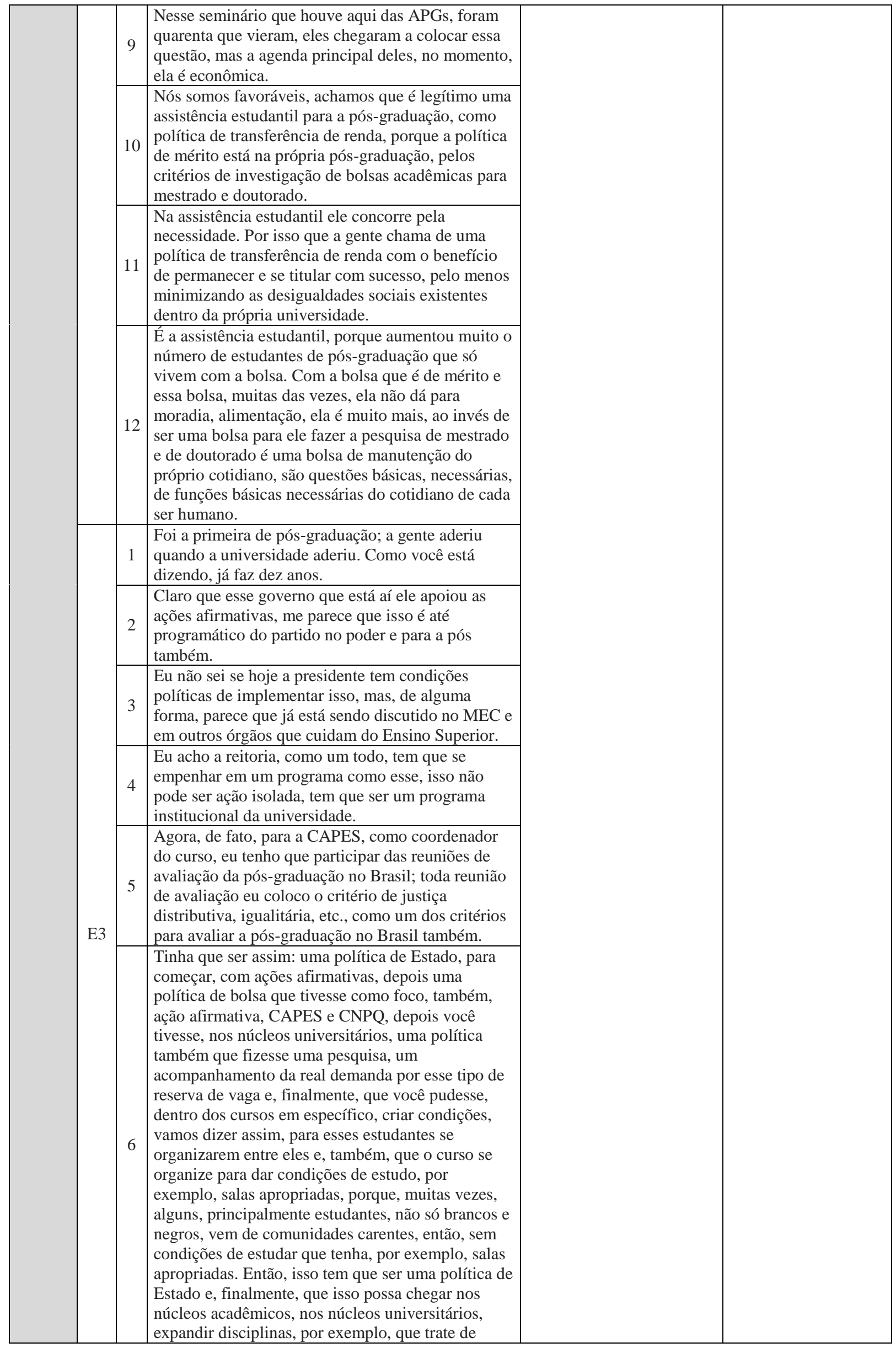




\begin{tabular}{|c|c|c|c|c|c|}
\hline & & & $\begin{array}{l}\text { pensamento negro no Brasil, história dos negros no } \\
\text { Brasil, etc., para também criar uma identidade mais } \\
\text { consciente, vamos dizer assim, da posição que o } \\
\text { negro ocupa na nossa própria história e identidade. } \\
\text { Não adianta, por exemplo, que cursos de } \\
\text { Engenharia não dê condições, por exemplo, de que } \\
\text { esses alunos negros possam estar fazendo estágio } \\
\text { em várias empresas. Sabemos que as empresas, às } \\
\text { vezes, tem políticas raciais muito explícitas, não } \\
\text { contratam negros, tem pesquisas que mostram isso, } \\
\text { então, que de forma que o curso possa se engajar } \\
\text { para arranjar essas vagas de estágio. }\end{array}$ & & \\
\hline & & 7 & $\begin{array}{l}\text { Então, quer dizer, a política é muito mais ampla } \\
\text { obviamente; a gente acredita que a política } \\
\text { afirmativa aqui no departamento de Sociologia, ela } \\
\text { ainda é uma atitude, uma postura, vamos dizer } \\
\text { assim, muito iniciante, tímida, mas a gente acredita } \\
\text { que é desse tipo de esforço que pode aparecer } \\
\text { processos mais amplos de mudança. Enfim... }\end{array}$ & & \\
\hline & & 8 & $\begin{array}{l}\text { A CAPES não vai saber quais alunos são de ação } \\
\text { afirmativa e quais nãos são. É claro que, ao fim, vai } \\
\text { ser uma média, por exemplo, de defesa. Qual foi a } \\
\text { média de defesa do Programa nos cursos de } \\
\text { Mestrado e Doutorado e depois qual foi a } \\
\text { publicação dos estudantes de Mestrado e } \\
\text { Doutorado. }\end{array}$ & & \\
\hline & & 1 & $\begin{array}{l}\text { A grande maioria dos cursos foram criados mais } \\
\text { recentemente e, hoje em dia, a Universidade de } \\
\text { Brasília é a terceira universidade do país com mais } \\
\text { número de curso de pós-graduação stricto sensu. } \\
\text { Em primeiro lugar é a USP, em segundo lugar a } \\
\text { UFRJ. }\end{array}$ & & \\
\hline & E1 & 2 & $\begin{array}{l}\text { Só em 2014, quando a Sociologia veio conversar } \\
\text { comigo, o coordenador da Sociologia e da } \\
\text { Antropologia, também, perguntando sobre como é } \\
\text { que a câmera aceitaria a reserva de vagas para } \\
\text { negro e para indígena no edital. Eu falei: Eu tenho } \\
\text { que passar para a câmara, então, você sugere na } \\
\text { reunião e a gente discute na reunião, então, foi } \\
\text { sugerido, no final do ano passado de } 2014 \text {, e o que } \\
\text { ficou decidido, que cada programa decide. }\end{array}$ & $\begin{array}{l}\text { - Primeiras iniciativas da } \\
\text { UnB nos cursos } \\
\text { Antropologia, Sociologia, } \\
\text { Direito e Direitos } \\
\text { Humanos e Cidadania. } \\
\text { 2- DAC estuda estender } \\
\text { auxílio financeiro à pós- } \\
\text { graduação }\end{array}$ & \\
\hline 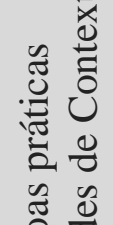 & & 3 & $\begin{array}{l}\text { Então, hoje, o que que já aconteceu? Dois editais da } \\
\text { Sociologia 2004, 2015, geralmente, entre dez e } \\
\text { vinte por cento de vagas, a Antropologia, também, } \\
\text { e o Direito começou esse semestre e o Direitos } \\
\text { Humanos e Cidadania outro curso que começou, } \\
\text { também, esse semestre. }\end{array}$ & $\begin{array}{l}\text { 3- Associação de } \\
\text { estudantes demandas por } \\
\text { um modelo institucional } \\
\text { 4- Fora da UnB a UFRJ foi }\end{array}$ & $\begin{array}{l}\text { 2- Implantações e } \\
\text { desdobramentos }\end{array}$ \\
\hline ค & & 4 & $\begin{array}{l}\text { Nem precisava, não é? Setenta por cento de negro } \\
\text { na Bahia e tem que ter cota? Que coisa. E só olhar } \\
\text { para lá mesmo, tem preto na Bahia então tem que } \\
\text { colocar na universidade. (UNEB) }\end{array}$ & $\begin{array}{l}\text { a primeira a implantar } \\
\text { reserva de vagas na pós no } \\
\text { curso de Antropologia } \\
\text { Social, do Museu Nacional }\end{array}$ & \\
\hline$己$ & & 1 & $\begin{array}{l}\text { Atualmente, a gente está fazendo um levantamento } \\
\text { de todas as linhas de pesquisa sobre essas quatro } \\
\text { áreas da Diretoria da Diversidade, todas as linhas } \\
\text { de pesquisa, os temas que são trabalhados, o que } \\
\text { une isso? Gênero, etnia e raça, inclusive para ver as } \\
\text { lacunas de pesquisa que tem nesta área da } \\
\text { diversidade, gênero, etnia e raça para que a gente } \\
\text { possa fomentar, fazer seminários, pesquisas, } \\
\text { incentivar algum outro tipo de política. }\end{array}$ & $\begin{array}{l}\text { 5- Sociologia prioriza } \\
\text { bolsas de estudo e curso } \\
\text { preparatório de inglês para } \\
\text { a população negra e } \\
\text { cotista. } \\
\text { 6- Aparente qualidade } \\
\text { igualitária entre cotistas e }\end{array}$ & \\
\hline & & 2 & $\begin{array}{l}\text { O Decanato é tido como uma área meio; há uma } \\
\text { discussão sobre isso, também, se o Decanato seria } \\
\text { área meio ou não. Eu acho que deveria ser um } \\
\text { Decanato acadêmico, ele é transversal, o que nós } \\
\text { estamos fazendo é transversal a todas as ações de } \\
\text { ensino, pesquisa e extensão }\end{array}$ & & \\
\hline
\end{tabular}









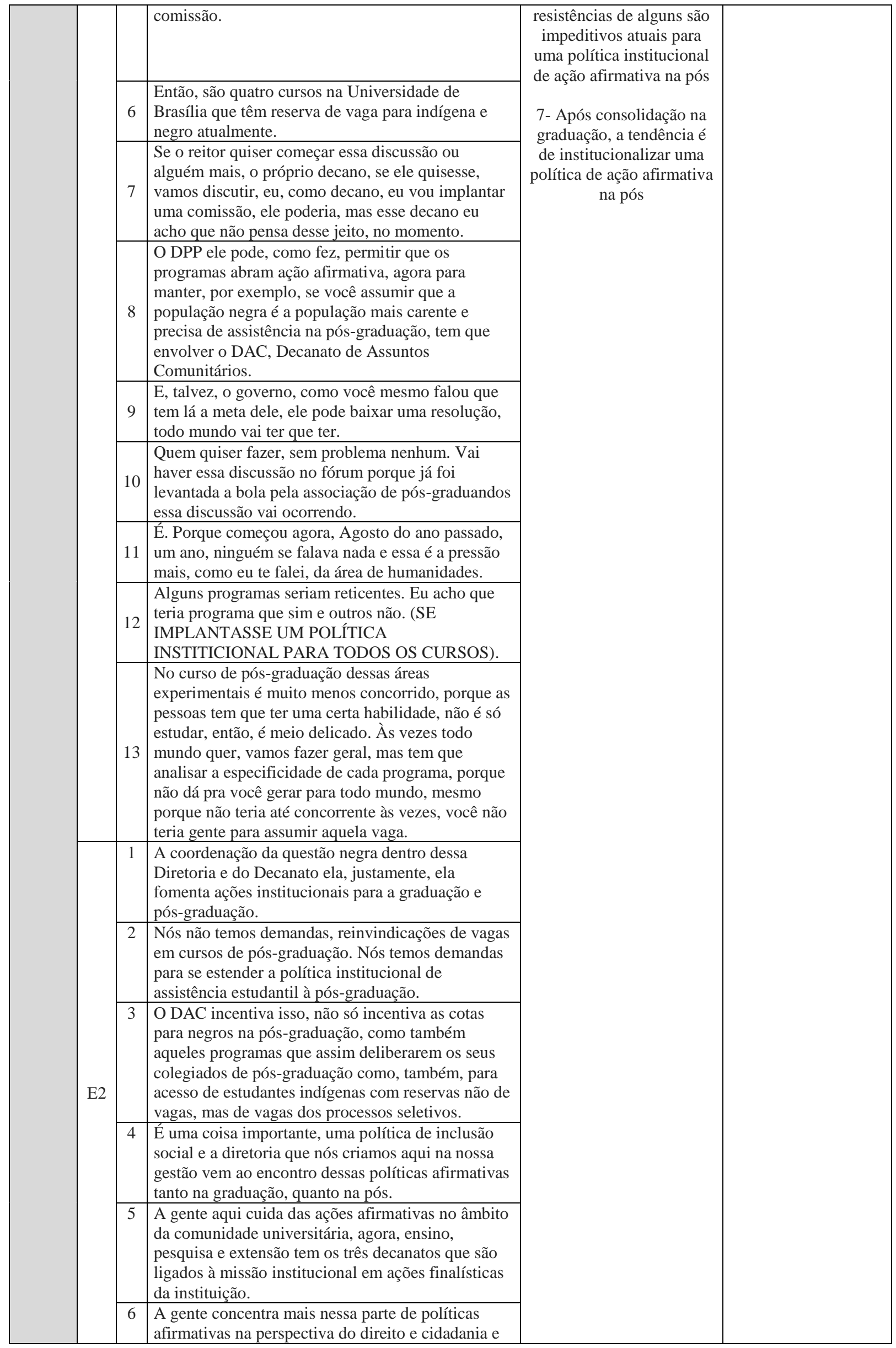




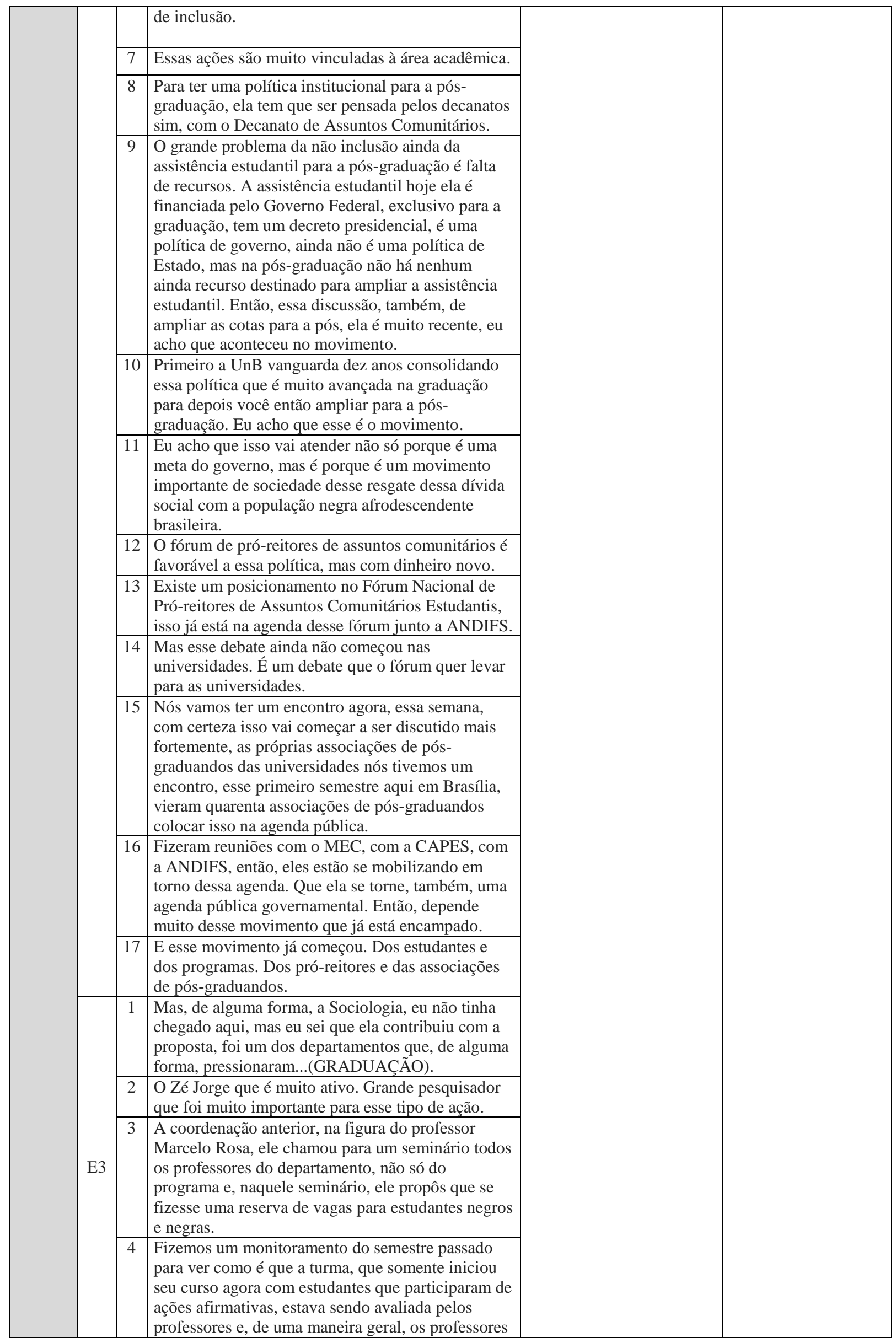




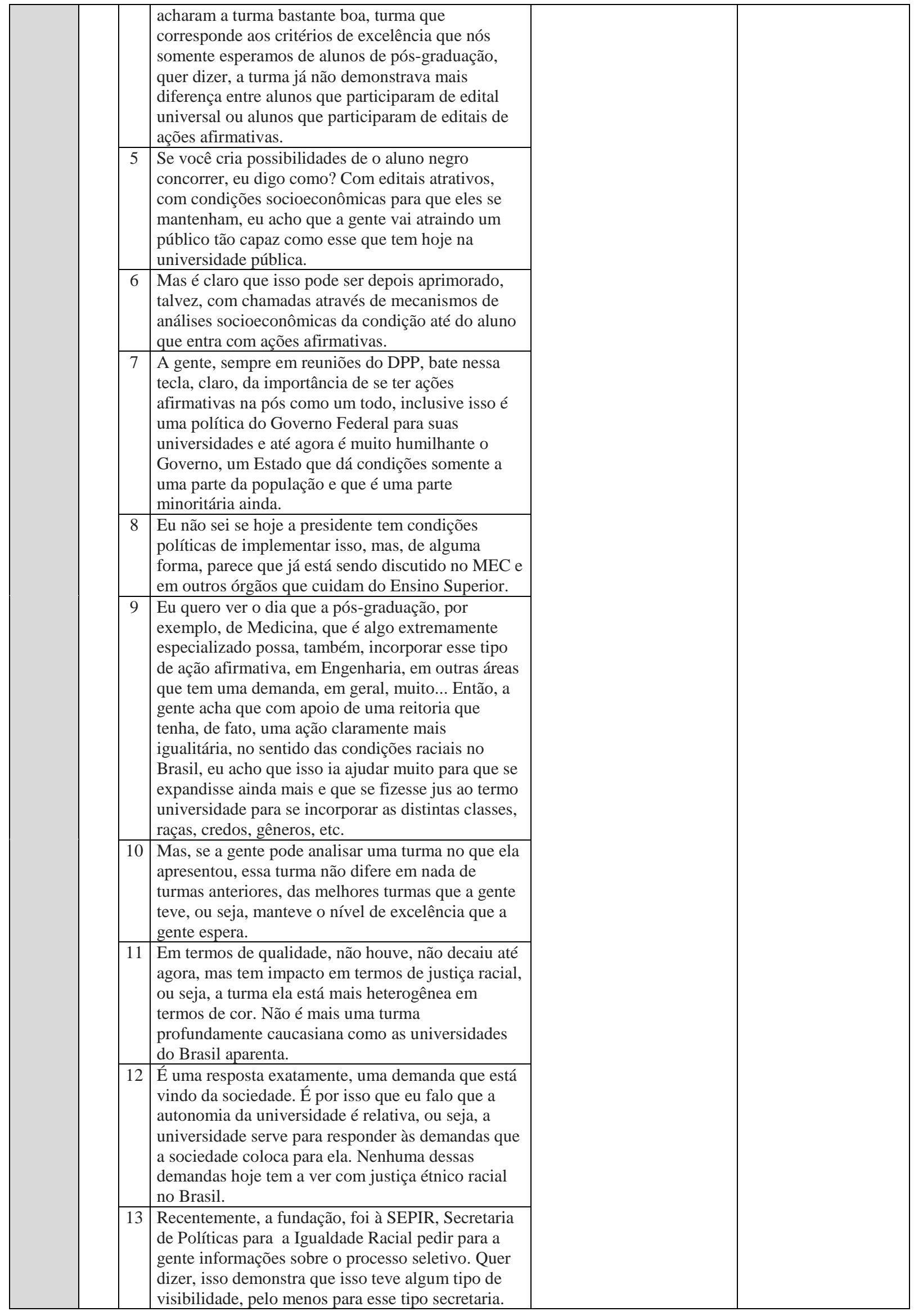




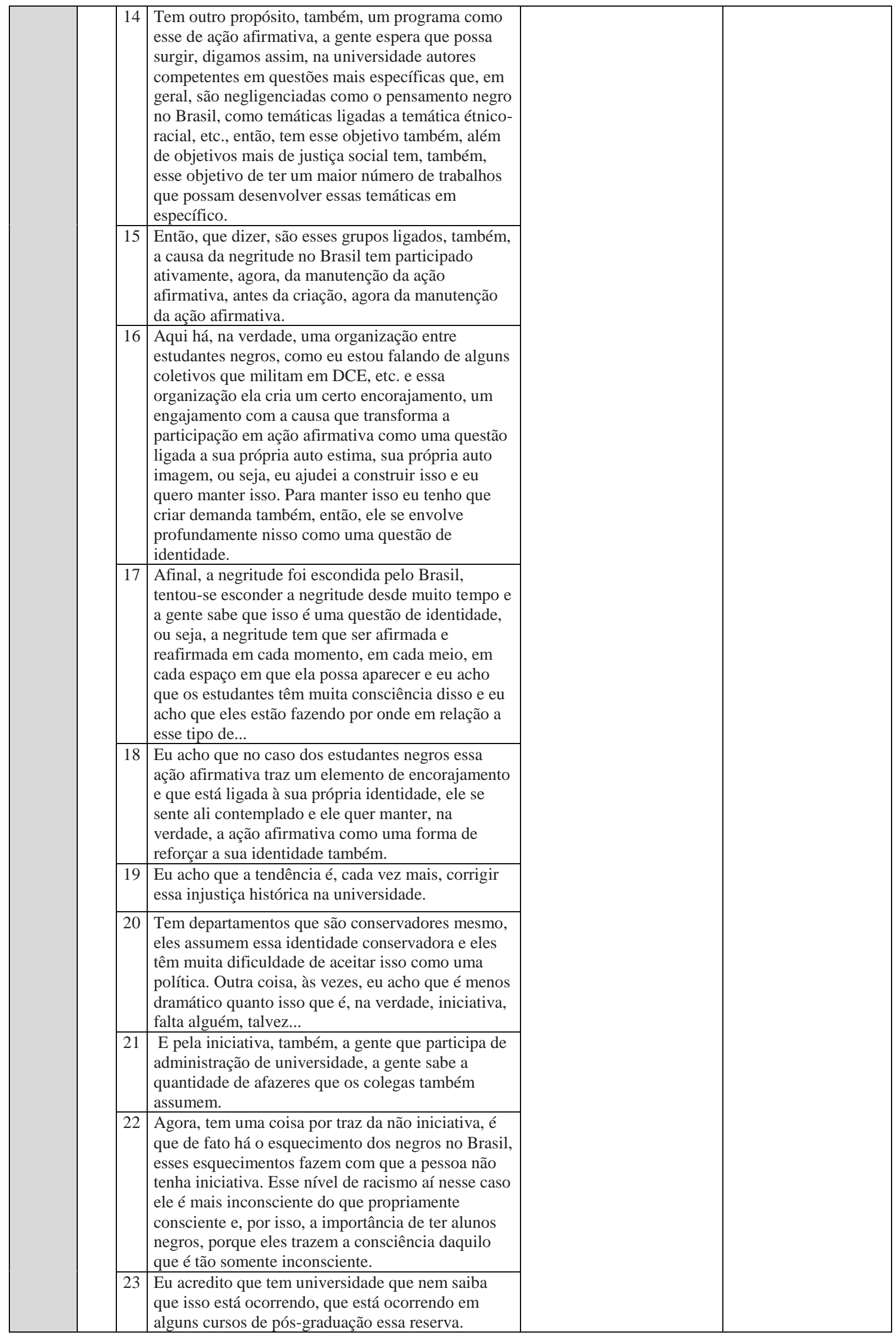




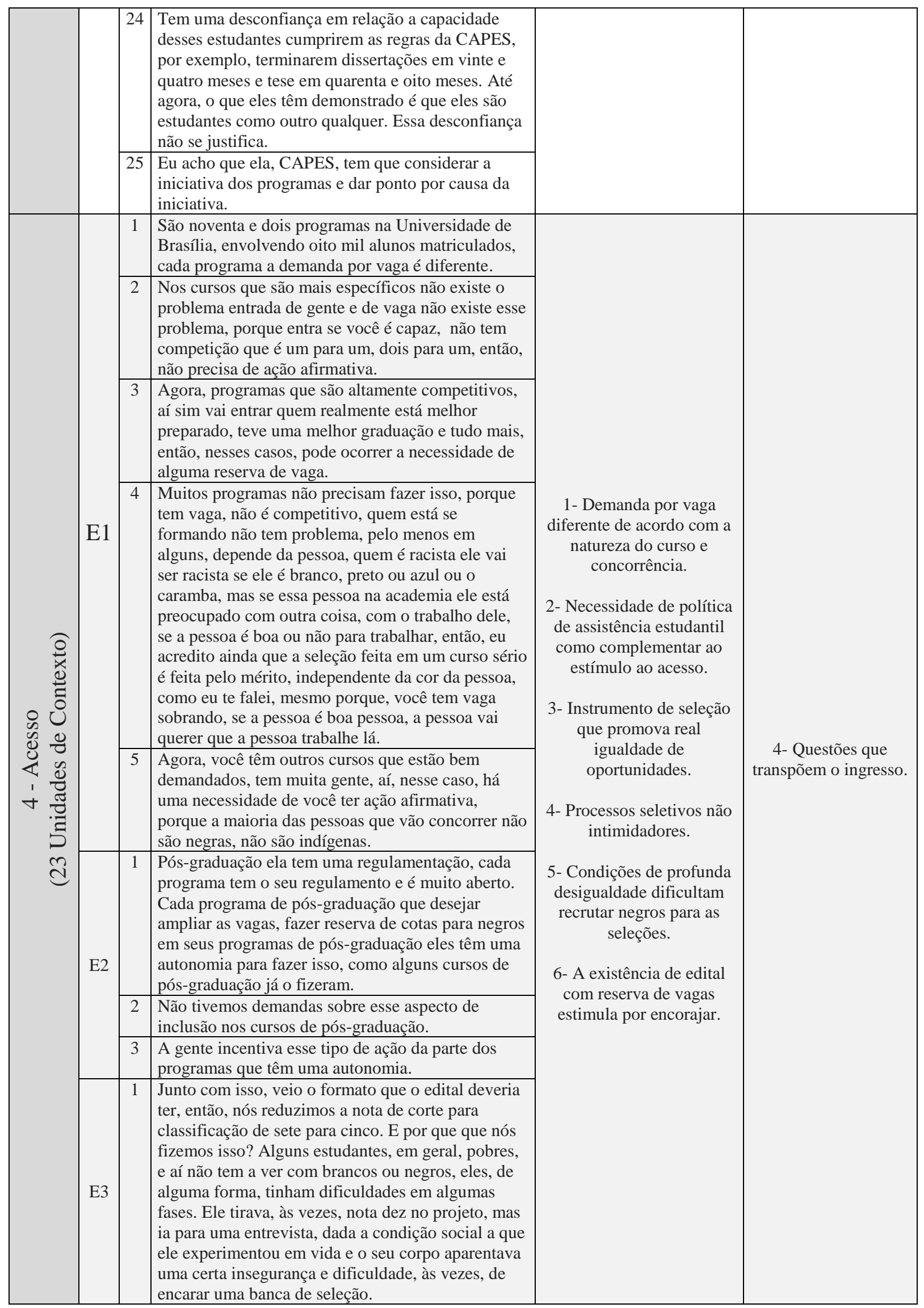




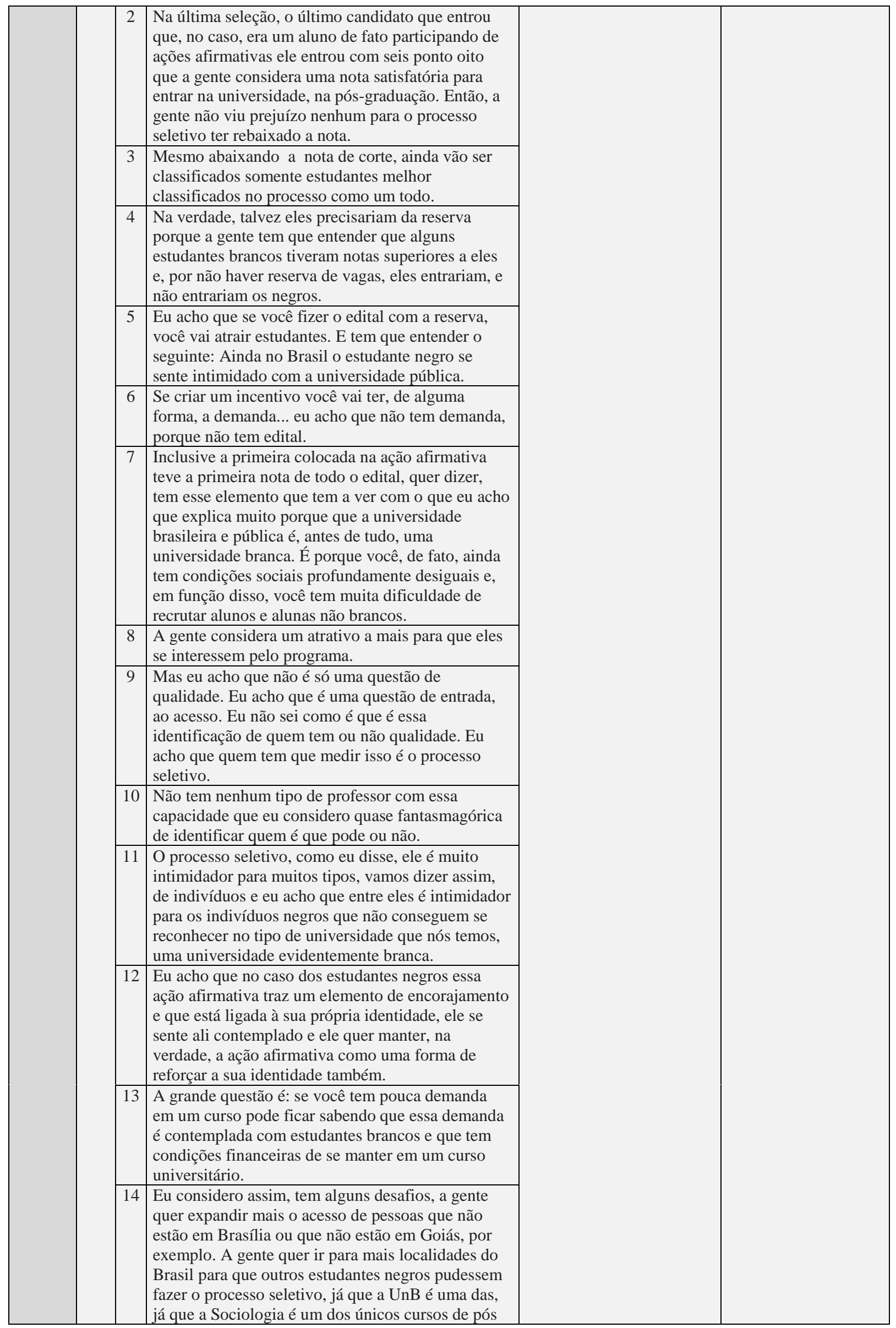




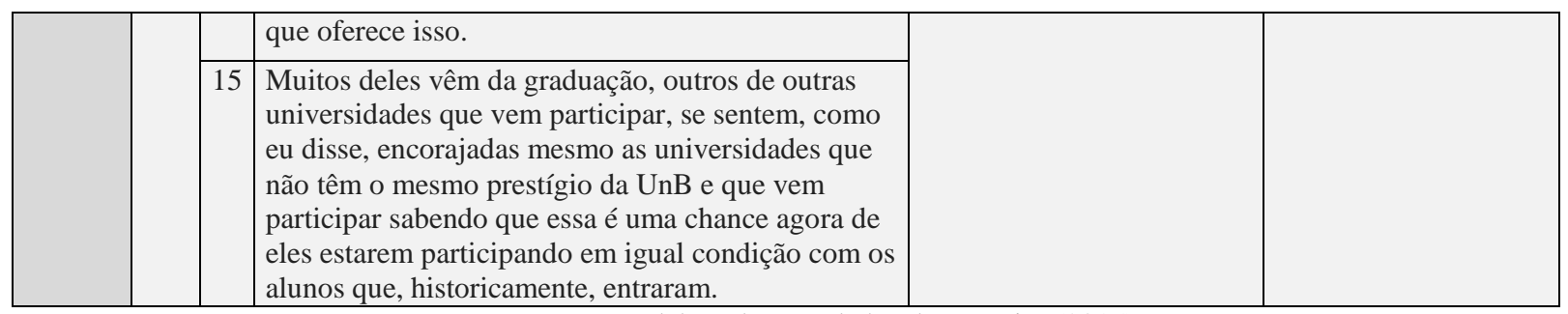

Fonte: Elaborado com dados da pesquisa (2015) 


\section{RESULTADOS E DISCUSSÕES}

Esta pesquisa visou a analisar as ações de ampliação ao acesso da população negra aos cursos de Pós-graduação stricto sensu da Universidade de Brasília entre 2004 a 2015. Os resultados retomam a questão inicial: a ampliação ao acesso da população de negros aos cursos de pós-graduação stricto sensu da Universidade de Brasília tem atendido às demandas das pressões sociais? Partiu-se da suposição de que a UnB pouco tem se esforçado institucionalmente para atender às demandas por uma política pública de ação afirmativa que estimule a ampliação ao acesso da população nos cursos de pós-graduação stricto sensu.

O estudo foi feito sob duas perspectivas que foram chamadas de dimensões: 1) a do histórico das ações afirmativas de estímulo ao acesso da população negra à educação superior brasileira, a qual contribuiu para compreensão desse contexto geral e para entender de que forma a Universidade de Brasília nele se insere; e, 2) a das políticas públicas de ações afirmativas na pós-graduação stricto sensu, propriamente ditas. O recorte temporal foi a última década, por ser considerada o período no qual ocorreu uma consolidação das ações afirmativas na graduação e, observados movimentos para a construção de uma política pública de ação afirmativa institucional para acesso da população negra também a cursos de pósgraduação stricto sensu.

Por meio da revisão teórica, constata-se um conhecimento acumulado sobre aspectos que envolvem o tema como racismo, raça, cultura, discriminação, desigualdade racial e social, e, acesso da população negra ao Ensino Superior. Por esse motivo, acredita-se que um estudo com a abordagem e recorte definidos poderá trazer contribuições agregadoras.

A análise dos documentos possibilitou descrever principalmente os resultados expostos na sequencia, que elucidam o contexto histórico em que o fenômeno ações afirmativas estão inseridos de forma ampla, até chegar ao foco desse estudo. $\mathrm{O}$ aprofundamento na Universidade de Brasília, por intermédio da análise de conteúdo, demonstrou que a instituição está inserida no contexto geral de inexistência de política pública de ação afirmativa direcionada ao acesso na pós-graduação stricto sensu de forma 
institucional e que ela compõe o grupo de universidades pioneiras em implantar reservas de vagas por iniciativas isoladas de unidades acadêmicas ligadas à Antropologia, à Sociologia, ao Direito e aos Direitos Humanos e Cidadania.

O quadro 9 traz a visão geral da pesquisa e de seus eixos e do caminho percorrido para se chegar aos resultados.

Quadro 9 - Modelo Analítico de Pesquisa

\begin{tabular}{|c|c|c|c|}
\hline \multicolumn{4}{|c|}{ MODELO ANALÍTICO DE PESQUISA } \\
\hline \multicolumn{4}{|c|}{ PROBLEMA/QUESTÃO } \\
\hline \multicolumn{4}{|c|}{$\begin{array}{c}\text { A ampliação ao acesso de alunos negros nos cursos de pós-graduação stricto sensu da Universidade de } \\
\text { Brasília tem atendido às demandas das pressões sociais? }\end{array}$} \\
\hline \multicolumn{4}{|c|}{ SUPOSIÇÃO } \\
\hline \multicolumn{4}{|c|}{$\begin{array}{l}\text { A UnB pouco tem ser esforçado institucionalmente para atender às demandas por uma política pública } \\
\text { de ação afirmativa que estimule a ampliação ao acesso da população negra nos cursos de pós- } \\
\text { graduação stricto sensu. }\end{array}$} \\
\hline \multicolumn{4}{|c|}{ OBJETIVO GERAL } \\
\hline \multicolumn{4}{|c|}{$\begin{array}{l}\text { Analisar as ações de ampliação ao acesso da população negra em cursos de pós-graduação stricto } \\
\text { sensu da Universidade de Brasília entre } 2004 \text { a } 2015\end{array}$} \\
\hline \multicolumn{4}{|c|}{ OBJETIVOS ESPECÍFICOS } \\
\hline $\begin{array}{l}\text { 1- Descrever o histórico das } \\
\text { políticas públicas de educação } \\
\text { superior que adotam ações } \\
\text { afirmativas praticadas nas } \\
\text { universidades públicas do Brasil. }\end{array}$ & $\begin{array}{l}\text { 2- Descrever/caracterizar } \\
\text { as boas práticas das } \\
\text { políticas de ações } \\
\text { afirmativas em } \\
\text { programas de pós- } \\
\text { graduação stricto sensu. }\end{array}$ & \begin{tabular}{|l} 
3- Descrever o cenário das \\
ações afirmativas adotadas na \\
Universidade de Brasília para \\
acesso de negros em cursos de \\
pós-graduação stricto sensu, \\
no período de 2004 a 2015.
\end{tabular} & $\begin{array}{l}\text { 4- Identificar as } \\
\text { dificuldades ao acesso da } \\
\text { população negra aos } \\
\text { Programas de Pós- } \\
\text { graduação stricto sensu } \\
\text { ofertados pela } \\
\text { Universidade de Brasília } \\
\text { sob a perspectiva da } \\
\text { instituição. }\end{array}$ \\
\hline \multicolumn{4}{|c|}{ DIMENSÕES } \\
\hline \multicolumn{2}{|c|}{$\begin{array}{l}\text { I - Histórico de políticas públicas a ação } \\
\text { afirmativa no ensino superior. }\end{array}$} & \multicolumn{2}{|c|}{$\begin{array}{l}\text { II - Ações Afirmativas na pós-graduação } \\
\text { stricto sensu. }\end{array}$} \\
\hline \multicolumn{4}{|c|}{ CATEGORIAS TEÓRICAS } \\
\hline 1 - Políticas Públicas & 2 - Boas práticas & 3- Ações Afirmativas & 4 - Dificuldades \\
\hline \multicolumn{4}{|c|}{ CATEGORIAS FINAIS } \\
\hline $\begin{array}{l}\text { 1- Gestão de Política } \\
\text { Pública }\end{array}$ & $\begin{array}{l}2 \text { - Implantações e } \\
\text { desdobramentos }\end{array}$ & 3- Institucionalização & $\begin{array}{l}4 \text { - Questões que } \\
\text { transpõem o } \\
\text { ingresso }\end{array}$ \\
\hline \multicolumn{4}{|c|}{ PERCURSO METODOLÓGICO } \\
\hline \multirow{3}{*}{\multicolumn{2}{|c|}{ Abordagem de pesquisa: }} & \multicolumn{2}{|c|}{ Sumpieri et al (2006); Alyrio (2009) Grawitz (1975) } \\
\hline & & \multicolumn{2}{|c|}{ Sumpieri et al (2006); Alyrio (2009) } \\
\hline & & \multicolumn{2}{|l|}{ Hair et al (2005) } \\
\hline \multirow[t]{2}{*}{ Técnicas de coleta de dados: } & Pesquisa documental & \multicolumn{2}{|c|}{$\begin{array}{l}\text { Sumpieri et al (2006); Alyrio (2009); Grawitz (1975), } \\
\text { Hair et al (2005); Bardin (2004) }\end{array}$} \\
\hline & Entrevistas semiestruturadas & \multicolumn{2}{|c|}{$\begin{array}{l}\text { Sumpieri et al (2006); Alyrio (2009); Grawitz (1975), } \\
\text { Hair et al (2005); Bardin (2004) }\end{array}$} \\
\hline \multicolumn{2}{|c|}{ Técnicas de Análise de Dados: Análise documental } & \multicolumn{2}{|c|}{$\begin{array}{l}\text { Sumpieri et al (2006); Alyrio (2009); Grawitz (1975), } \\
\text { Hair et al (2005); Bardin (2004) }\end{array}$} \\
\hline
\end{tabular}




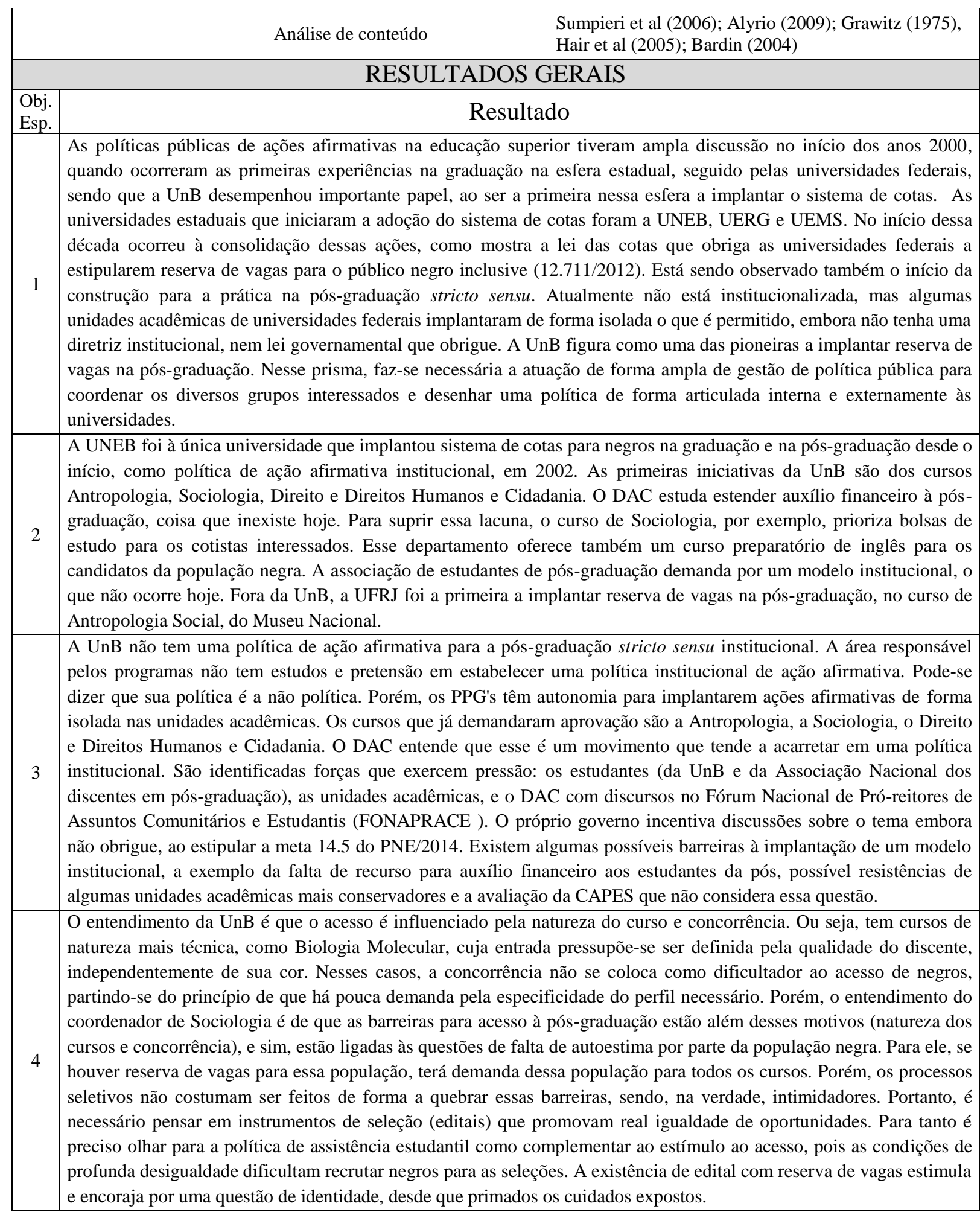

Fonte: Elaboração própria.

O item 4.1 discorre sobre os resultados obtidos por meio da análise de documento, ancorada na revisão teórica. Já o item 4.2 expõe os resultados da análise de conteúdo das entrevistas semiestruturadas. 


\title{
4.1 RESULTADOS GERADOS PELA ANÁLISE DOCUMENTAL
}

\subsubsection{O Histórico das Políticas Públicas de Educação Superior que Adotam Ações Afirmativas nas Universidades Públicas do Brasil}

A experiência brasileira mostra que nos anos 90 surgiram tentativas de implantação de ações afirmativas, que, segundo Contins e Sant'ana (1996), foram reflexo do resurgimento do movimento negro na década de 70 , por meio do qual "as organizações que discutem a questão racial desenvolveram um trabalho significativo pondo em exposição as desigualdades existentes entre brancos e negros" (CONTINS \& SANT'ANA, 1996, p. 215). De acordo com os autores, na época já havia o entendimento que seria necessário seguir esse caminho, a fim de avançar com proposições, realizações e garantias à realização de políticas públicas governamentais, ou não, que atendessem à população negra. Mesmo com essa compreensão, o caráter de conflito de opiniões, desde então, é percebido, como evidenciado pelos autores, quando afirmam:

\begin{abstract}
neste sentido posições contra e a favor de ação afirmativa, ação compensatória, política de cotas e discriminação positiva integram uma discussão atual e revitalizada no centro do movimento negro. Estes debates levam em conta a conjuntura internacional e nacional à situação da população negra brasileira, os mecanismos de discriminação e a política da democracia racial para avaliar a eficácia da ação afirmativa como instrumento de combate a discriminação (CONTINS e SANT'ANA, op.cit., p. 215)
\end{abstract}

À época, uma série de ações não governamentais cobrou a inclusão de ações afirmativas em seus projetos na iniciativa privada, momento em que registrou-se também a criação de projetos de leis com o teor antidiscriminatório na iniciativa pública, com destaque para a coletânea organizada pelo então deputado federal Abdias do Nascimento, Combate ao Racismo (1983, 1984). Houve reflexo no setor de educação como "a oferta de bolsas de estudos universitários para negros, a instituição de meios concretos que garantam o ingresso de negros no Instituto Rio Branco e outros" (CONTINS e SANT’ANA, op.cit., p. 216). No Rio de Janeiro foi onde se registrou iniciativas experimentais de ação afirmativa, podendo-se citar os cursos de pré-vestibular oferecidos ao público de pessoas negras e carentes. Segundo pesquisado pelos autores, provavelmente, essa foi a ação que atingiu diretamente um maior 
número de pessoas não brancas, pelo fato de lidarem "diretamente com um público beneficiado maior que o dos outros cursos, além do número de agenciadores do projeto (professores e pessoal da administração) ser também o mais significativo" (CONTINS e SANT'ANA, 1996, p. 216).

Essa posição é de certa forma confirmada por Carvalho (2007), quando afirma que o instrumento utilizado para ingresso no Ensino Superior é o edital de vestibular na graduação, e os editais de seleção em cursos de pós-graduação. Para o autor, a maior barreira para a igualdade étnico-racial no Ensino Superior no Brasil é a existência de um vestibular universal, o qual para o autor não representa oportunidade igual, e sim, trata-se de uma forma excludente ao acesso. Outro aspecto que reforça esse caráter, para o autor, é o mercado dos cursinhos, cujo público exclui negros e carentes que têm maior chance de ingressar no Ensino Superior, por esse instrumento.

Com todas as dificuldades, o Brasil vem adotando Políticas Públicas de Ação Afirmativa em diversos setores e esferas de governo, como: a concessão de bolsas de estudo; a prioridade em empréstimos e contratos públicos; a distribuição de terras e moradias; medidas de proteção diferenciada para grupos ameaçados; entre outros (BRASIL, 2014), além de ações afirmativas (Cotas/Prouni) e até mesmo a Lei das Cotas em seleção de concursos públicos da esfera federal. Porém, o foco das ações afirmativas, quando se trata do Ensino Superior é a graduação, sendo que pouco tem sido feito para a diminuição das desigualdades étnico-raciais na pós-graduação stricto sensu no Brasil, como observado a seguir.

\subsubsection{A Perspectiva do Arcabouço Jurídico para Ações Afirmativas no Ensino Superior nas Universidades Públicas}

Por meio da análise de documento, foi possível verificar o arcabouço jurídico brasileiro no que tange o Ensino Superior e as ações afirmativas de combate às desigualdades étnico-raciais. Os marcos que mais contribuíram de forma gradativa para o cenário favorável às ações afirmativas no Brasil estão sintetizados na figura a seguir. 
Figura 4 - Marcos para Consolidação das Ações Afirmativas

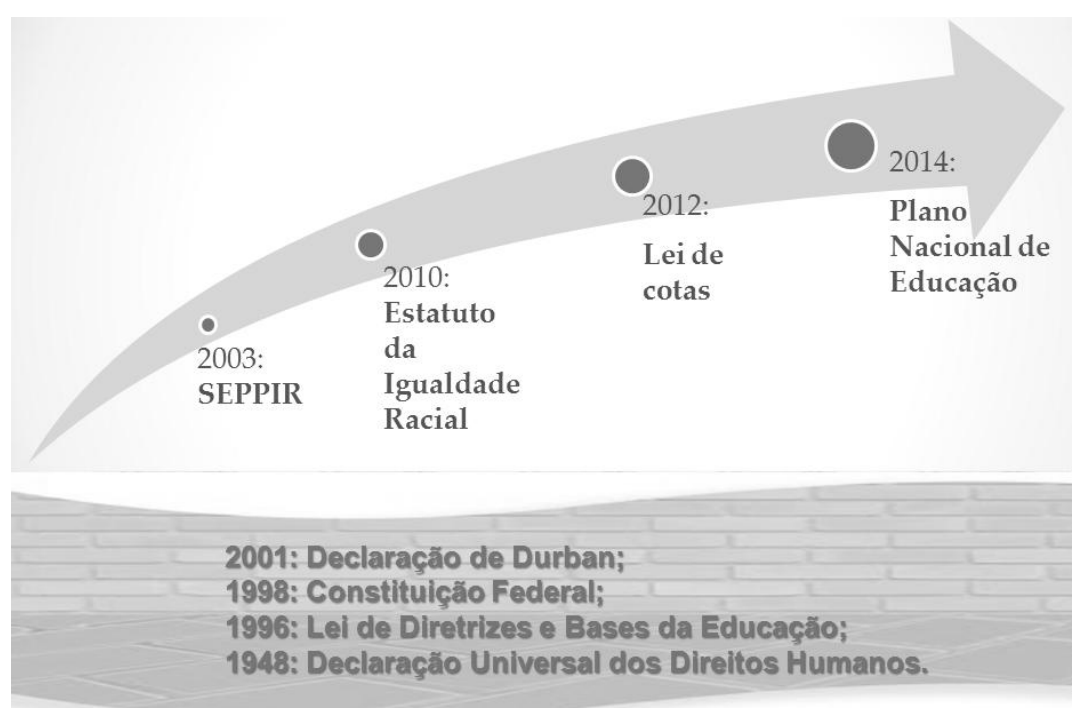

\section{- Carta Internacional de Direitos Humanos, 10 de Dezembro de 1948 - Declaração Universal dos Direitos Humanos:}

Embora não tenha força de lei, a carta reflete um modelo ideal por nações no mundo inteiro. Em seu Art. $2^{\circ}$ fica explícita a intenção em discursar sobre a igualdade étnicoracial, entre outras.

Artigo $2^{\circ}$ : Todos os seres humanos podem invocar os direitos e as liberdades proclamados na presente Declaração, sem distinção alguma, nomeadamente de raça, de cor, de sexo, de língua, de religião, de opinião política ou outra, de origem nacional ou social, de fortuna, de nascimento ou de qualquer outra situação. Além disso, não será feita nenhuma distinção fundada no estatuto político, jurídico ou internacional do país ou do território da naturalidade da pessoa, seja esse país ou território independente, sob tutela, autônomo ou sujeito a alguma limitação de soberania (PARIS, 1948, p. 1).

Esse documento é considerado o marco inicial e universal para fundamentar as ações afirmativas, bem como para incluir o tema na agenda política, segundo Santos (2012).

- Lei n. ${ }^{\circ}$ 9.394, de 20 de Dezembro de 1996 - Lei de Diretrizes e Bases da Educação

Como expresso no título, são diretrizes de sustentação da educação, sem muito detalhamento, o que é feito em âmbitos específicos correspondentes. Ela expressa a intenção 
de igualdade de condições, não só ao acesso, mas também de permanência em todos os graus de educação.

Art. $3^{\circ} \mathrm{O}$ ensino será ministrado com base nos seguintes princípios: I - igualdade de condições para o acesso e permanência na escola. (Lei n. ${ }^{\circ}$ 9.394, de 20 de Dezembro de 1996, p. 1)

Em razão de não detalhar, concede autonomia para as instituições em suas esferas municipal estadual e federal - para organizarem seus sistemas de ensino sob a coordenação da União.

Art. $8^{\circ}$ A União, os Estados, o Distrito Federal e os Municípios organizarão, em regime de colaboração, os respectivos sistemas de ensino.

$\S 1^{\circ}$ Caberá à União a coordenação da política nacional de educação, articulando os diferentes níveis e sistemas e exercendo função normativa, redistributiva e supletiva em relação às demais instâncias educacionais.

$\S 2^{\circ}$ Os sistemas de ensino terão liberdade de organização nos termos desta Lei ; (Lei n. ${ }^{\circ}$ 9.394, de 20 de Dezembro de 1996, p. 4)

\section{- Constituição Federal de 1988:}

Determina a criação de um plano nacional de educação, considerado o detalhamento da Lei das Diretrizes Bases da Educação.

Art. 214. A lei estabelecerá o plano nacional de educação, de duração decenal, com o objetivo de articular o sistema nacional de educação em regime de colaboração e definir diretrizes, objetivos, metas e estratégias de implementação para assegurar a manutenção e desenvolvimento do ensino em seus diversos níveis, etapas e modalidades por meio de ações integradas dos poderes públicos das diferentes esferas federativas que conduzam a Redação dada pela Emenda Constitucional n. ${ }^{\circ}$ 59, de 2009.

I - erradicação do analfabetismo;

II - universalização do atendimento escolar;

III - melhoria da qualidade do ensino;

IV - formação para o trabalho;

V - promoção humanística, científica e tecnológica do país.

VI - estabelecimento de meta de aplicação de recursos públicos em educação como proporção do produto interno bruto. (Incluído pela Emenda Constitucional n. ${ }^{\circ}$ 59, de 2009).(CF 1988, Art. 214º))

O MEC lançou, por meio da Lei N. ${ }^{\circ}$ 13005/2014, o PNE para o período de dez anos, a contar da sua assinatura. 


\title{
- Declaração de Durban: 31 de Agosto a 8 de Setembro de 2001
}

É o marco histórico do reconhecimento do racismo no Brasil, a partir do qual mudou o cenário nacional em favor de concretização das ações afirmativas. A declaração faz uma série de reconhecimentos, expressões, lembranças, afirmações e declarações quanto ao racismo.

\begin{abstract}
MEDIDAS DE PREVENÇÃO, EDUCAÇÃO E PROTEÇÃO COM VISTAS À ERRADICAÇÃO DO RACISMO, DISCRIMINAÇÃO RACIAL, XENOFOBIA E INTOLERÂNCIA CORRELATA EM NÍVEIS NACIONAIS, REGIONAIS E INTERNACIONAIS.

76. Reconhecemos que a desigualdade de condições políticas, econômicas, culturais e sociais podem reproduzir e promover o racismo, discriminação racial, xenofobia e intolerância correlata, e têm como resultado a exacerbação da desigualdade. Acreditamos que a igualdade de oportunidades real para todos, em todas as esferas, incluindo a do desenvolvimento, é fundamental para a erradicação do racismo, discriminação racial, xenofobia e intolerância correlata. (DECLARAÇÃO DE DUBAN, 2001, p. 21)
\end{abstract}

Estabelece, a partir daí, um programa de ação, tendo como objetivo, entre outros, o de promoção da igualdade de oportunidades, a saber:

c) Desenvolver programas destinados aos afrodescendentes alocando recursos adicionais aos serviços de saúde, educação, moradia, energia elétrica, saneamento, medidas de controle ambiental e promover a igualdade de oportunidades no emprego, bem como em outras iniciativas de ações afirmativas ou positivas; (Declaração de Duban, 2001, p. 33)

123. (...) (g) Considerarem o estabelecimento de programas de assistência financeira desenhados para capacitar todos os estudantes, independente de raça, cor, descendência, origem étnica ou nacional a frequentarem instituições educacionais de Ensino Superior. (DECLARAÇÃO DE DUBAN/MEC, 2010, p. 62)

\section{- $\quad$ Lei n. ${ }^{\circ}$ 10.678, de 23 de Maio de 2003 - Secretaria Especial de Políticas de Promoção da Igualdade Racial (SEPPIR)}

Essa lei cria a SEPPIR, órgão de assessoramento imediato à Presidência da República, a Secretaria Especial de Políticas de Promoção da Igualdade Racial, responsável por formular, coordenar e avaliar políticas e diretrizes para a promoção da igualdade racial no Brasil. 


\title{
- $\quad$ Lei n. ${ }^{\circ}$ 12.288, de 20 de Julho de 2010 - Estatuto da Igualdade Racial
}

Essa lei contribui para a transversalidade das ações afirmativas as quais devem permear as políticas públicas.

\begin{abstract}
Art. $1^{\circ}$ Esta Lei institui o Estatuto da Igualdade Racial, destinado a garantir à população negra a efetivação da igualdade de oportunidades, a defesa dos direitos étnicos individuais, coletivos e difusos e o combate à discriminação e às demais formas de intolerância étnica.
\end{abstract}

\section{- Lei 12.711, de Agosto de 2012 - Lei das Cotas}

Garante reserva de $50 \%$ das matrículas por curso e turno nas 59 universidades federais e em 38 institutos federais de educação, ciência e tecnologia, a alunos oriundos integralmente do Ensino Médio público, em cursos regulares ou da educação de jovens e adultos. Os demais 50\% das vagas permanecem para ampla concorrência (MEC, 2014).

\section{- Decreto n. ${ }^{\circ}$ 7.824/2012 - Regulamente a Lei das Cotas}

Com a aprovação da Lei n. 12.711, em 29 de Agosto de 2012, que criou a política de reserva de vagas para alunos de escola pública, negros, pardos e indígenas em todo o sistema de educação superior, a realidade das políticas de ação afirmativa no país tende a se alterar significativamente. Isso torna ainda mais premente à tarefa de compreender o que foi feito até agora.

- $\quad$ Lei N. 13.005, de 15 de Junho de 2014 - Plano Nacional de Educação ( PNE)

O PNE contribui com a inclusão de estratégia e meta para estímulo ao acesso à população negra e outros grupos em cursos de pós-graduação stricto sensu. 
Art. $1^{\circ}$. É aprovado o Plano Nacional de Educação - PNE, com vigência por 10 (dez) anos, a contar da publicação desta Lei, na forma do Anexo, com vistas ao cumprimento do disposto no art. 214 da Constituição Federal.

\subsubsection{Os Pioneiros na Implantação de Ações Afirmativas nas Universidades Públicas do Brasil}

As primeiras iniciativas concretas para romper com a prática de vestibular universal para ingresso no Ensino Superior ocorreu na esfera estadual como evidencia Carvalho (2007). A criação da Lei estadual 4151, de 04 de Setembro de 2003, levou a Universidade Estadual do Rio de Janeiro (UERJ) a ser a pioneira na adoção do sistema de cotas na graduação, destinando " $50 \%$ de suas vagas no vestibular de 2003 para estudantes que cursaram o Ensino Médio em escolas da rede pública" (UERJ, 2014), com a realização de dois concursos: um para o Exame de Qualificação do Sistema de Acompanhamento do Desempenho dos Estudantes do Ensino Médio (SADE) e outro para o vestibular tradicional, ou universal. Nos dois foram incluídos cota para afrodescendentes, porém não foi incluído o

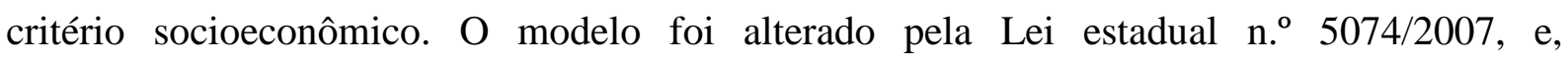
posteriormente, pela Lei estadual 5346/2008, sendo que no artigo $1^{\circ}$, alínea I, estabelece uma reserva de $20 \%$ (vinte por cento) para os estudantes negros e indígenas nos cursos de graduação.

O estado da Bahia foi contemporâneo ao Rio de Janeiro, com a decisão do Conselho dos Professores da Universidade Estadual da Bahia (UNEB) em deliberar pela cota de $40 \%$ das vagas de todos os núcleos serem reservadas para afrodescendentes. Para Carvalho (2007), a Bahia avançou um pouco mais quando englobou tanto a graduação quanto a pósgraduação na política. Essa modificação foi aprovada em 2002 e implementada no processo seletivo da turma de 2003, na gestão da ex-reitora Professora Doutora Ivete Sacramento, primeira reitora negra a dirigir uma universidade no país, 'modelo que passou a ser seguido por instituições de ensino superior em todo o país’ (BAHIA, 2012). 
$\mathrm{Na}$ Universidade Estadual de Mato Grosso do Sul (UEMG), o sistema de cotas para a graduação foi implantado após a criação da Lei n. ${ }^{\circ}$. 2.605, de 06 de Janeiro de 2003, a qual dispõe sobre a reserva de $20 \%$ das vagas para negros.

No âmbito federal, a Universidade de Brasília (UnB) foi a primeira a implementar ação afirmativa, por meio do sistema de cotas, o qual vigora desde o vestibular correspondente ao segundo semestre de 2004, um ano após as iniciativas estaduais da UERJ, UNEB e UEMG. "Tal sistema foi colocado em prática após muito debate e discussão por parte da comunidade acadêmica. A ideia era instaurar, no espaço acadêmico, um mecanismo reparador das perdas infringidas à população negra brasileira” (UNB, 2013, p. 4). Atualmente, o vestibular da UnB está dividido em: Ampla Concorrência (Sistema Universal), Sistema de Cotas para Escolas Públicas e o Sistema de Cotas para Negros da UnB (UNB, 2014).

Uma inovação foi implementada pela Universidade Federal de Minas Gerais (UFMG), valendo a pena tomarem conhecimento do seu modelo de ação afirmativa introduzida a partir de 2009. Peixoto e Braga afirmam que a formulação do programa de bônus partiu da explicitação de três premissas, a saber:

(...) em primeiro lugar, aumentar a proporção de estudantes aprovados egressos de escolas públicas e que se declaram como pretos ou pardos, de tal forma a, pelo menos, aproximá-los do observado no universo dos candidatos; em segundo lugar, produzir efeitos expressivos de inclusão social e étnico/racial sobre os cursos de elevado prestígio social, onde o alunado da UFMG é mais elitizado; em terceiro lugar, reverter à tendência de queda do número de candidatos oriundos da rede pública do ensino médio, observada a partir de 2002. (PEIXOTO \& BRAGA, 2012, p. 169-170)

O Relatório de Gestão referente ao ano 2011 dessa universidade informa que foi adotado o Programa de Bônus, consistindo em garantir " $10 \%$ no total de pontos obtidos pelos candidatos que cursaram pelo menos os três anos do Ensino Médio e os últimos quatro anos do Ensino Fundamental em escola pública", adicionalmente para "os candidatos desse mesmo grupo, que se declararam pretos ou pardos, foi estabelecido o acréscimo de mais 5\%, perfazendo $15 \%$ no total de pontos" (UFMG, 2011). 


\subsubsection{O caminho para a Implantação de Ações Afirmativas em Cursos de Pós- Graduação nas Universidades Públicas do Brasil}

A Lei das Cotas (12.711/2012) que impôs a reserva de vagas nas IFES, exclusivamente para a graduação, foi considerada a consolidação do sistema de cotas, o que ocorreu em 2012. Alguns sítios trazem a informação de unidades acadêmicas de universidades federais que implantaram reserva de vagas em pós-graduação stricto sensu nos três primeiros anos após a Lei das Cotas para a graduação: 2014 a UFRJ - PPG em Antropologia Social; 2015 a UnB - PPG em Sociologia e PPG em Antropologia; 2016 a UnB - PPG em Direito e PPG em Direitos Humanos e Cidadania.

Outras instituições federais com iniciativa similar são: Santa Catarina (UFSC), Pelotas (UFPel), e Pará (UFPA), com reserva de vagas nos PPG’s em Antropologia, Sociologia e Direito. A Universidade da Integração Internacional da Lusofonia Afro-brasileira (UNILAB), no Ceará e na Bahia, também possuem iniciativa parecida. Nessas universidades, a ação afirmativa se dá em um mestrado interdisciplinar que mescla Agronomia, Saúde e Engenharia. (ANDIFES, 2014).

\subsection{RESULTADOS GERADOS PELA ANÁLISE DE CONTEÚDO}

\subsubsection{Aprofundamento na Universidade de Brasília}

Os dados da análise de conteúdo foram codificados no quadro 7 desta pesquisa, o qual complementa o quadro 6 - Sistema de Categorização (Sintético) e o apêndice - Sistema de Categorização (Analítico). Portanto, quando citado algum código, remete-se a esse conjunto de informações sistematizadas, e a compreensão dos resultados dependem da interligação desses quadros. 


\section{- Categoria Final 1: Gestão de Política Pública}

Essa categoria final, ligada à categoria teórica Políticas Públicas na Dimensão Histórica, foi desenvolvida a partir do objetivo específico 1 - Descrever o histórico das políticas públicas de educação superior que adotam ações afirmativas praticadas nas universidades públicas do Brasil. Trata-se de uma visão macro de políticas públicas, permeada pelo aprofundamento na Universidade de Brasília.

As ações afirmativas para estímulo à população negra no Ensino Superior têm sido implantadas pelas instituições de Ensino Superior no âmbito da graduação, em sua maioria. Esse fato pode ser compreendido em razão do filtro natural entre um grau e outro. $\mathrm{O}$ volume de estudantes demandantes de vagas na graduação é maior do que na pós-graduação stricto sensu. Essa ponderação é importante para que seja possível a compreensão do motivo pelo qual o governo prioriza a graduação, onde é encontrada a barreira para acesso para o Ensino Superior. A figura 5 demonstra esse fato.

Figura 5 - Público Negro x Público Branco Ingressante no Ensino Superior

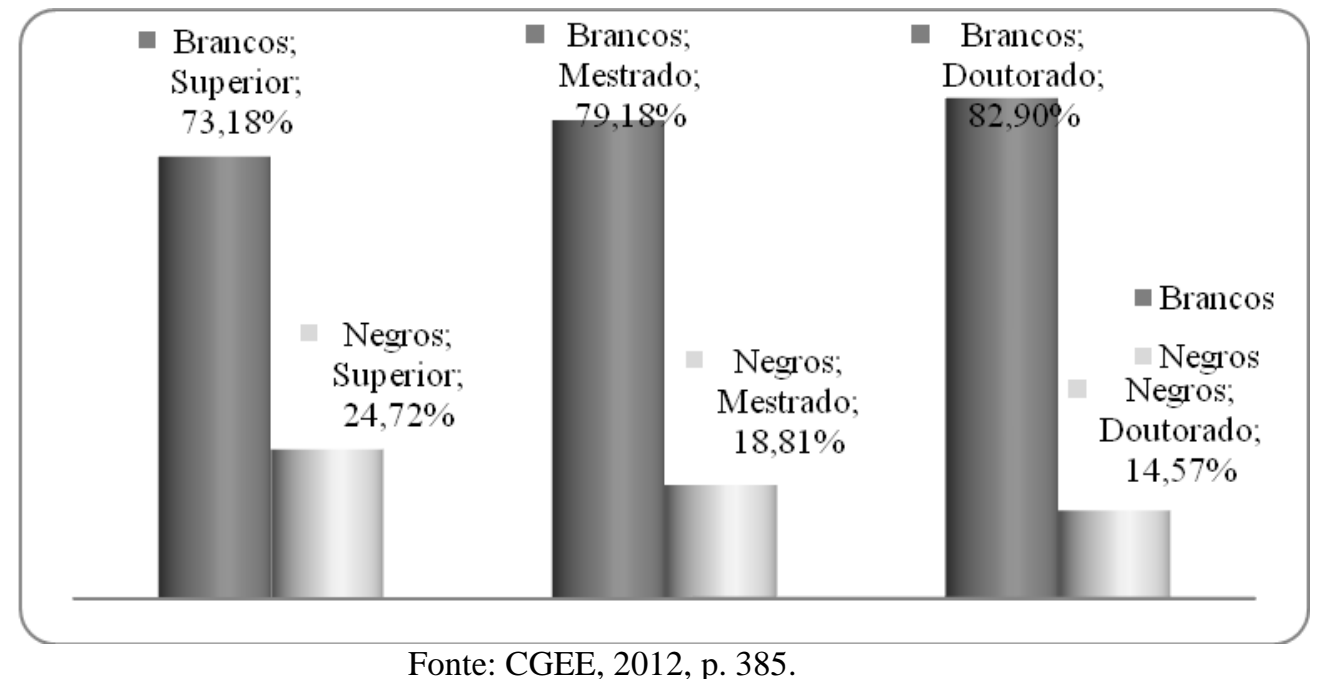

Fonte: CGEE, 2012, p. 385

No entanto, outra visão dos mesmos dados, na perspectiva de proporção, revela que a população de mestres e doutores negros é tanto inferior à branca à medida que avança o grau acadêmico. Observe a figura 6, a seguir. 
Figura 6 - Proporção de Público Negro x Público Branco por Grau no Ensino Superior

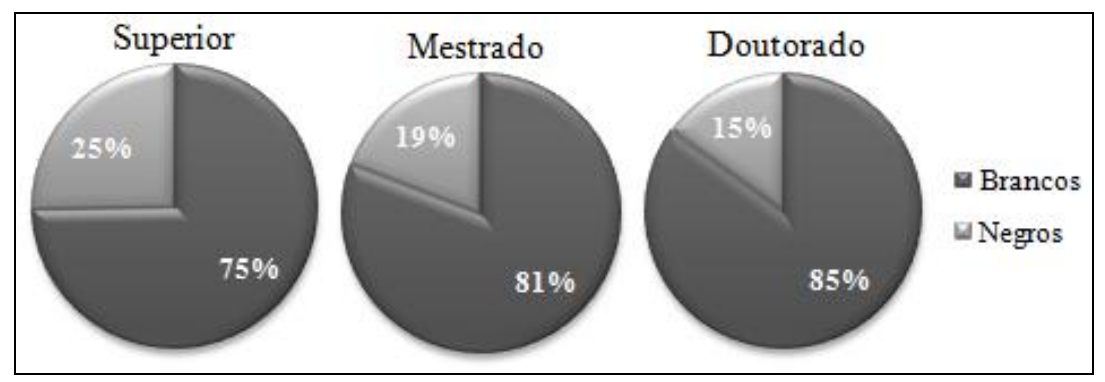

Fonte: CGEE, 2012, p. 385.

Constata-se que a pressão vem aumentando gradativamente, vinda de diversas áreas (sociedade, estudantes, unidades acadêmicas), para a ampliação do sistema de cotas para a pós-graduação. Essa pressão reflete uma lacuna social a qual, como explica Rua (1998), formam o campo de atuação de políticas públicas.

Embora tenha dado um passo para estimular essa tendência com a o Plano Nacional de Educação em 2014, o governo é demandado cada vez mais pela criação de uma política de ação afirmativa para a pós-graduação por força de lei, a exemplo da graduação. Assim, é uma questão mais ampla que desenhar uma política, e sim, envolve uma série de questões as quais necessitam de uma gestão de política pública voltada para a transversalidade de uma política articulada internamente nas universidades e com o governo, inclusive com previsão de recursos.

Na política atual da Universidade de Brasília, verifica-se a inexistência de uma política de ação afirmativa institucional para acesso de negros na pós-graduação stricto sensu. Porém, ela apoia as unidades acadêmicas que queiram implantar de forma isolada. Foi o que ocorreu com os PPG's em Antropologia, Sociologia e Direitos Humanos e Cidadania, em 2015, e Direito, programado para 2016.

As categorias intermediárias que sugerem essa categoria final são: 1 - ausência de política de ação afirmativa para a pós-graduação stricto sensu institucional; 2 - autonomia dos programas de pós-graduação para implantar reserva de vagas; 3 - necessidade de articulação interna entre DPP, DAC e unidades acadêmicas para viabilizar política pública de ação afirmativa institucional; 4 - necessidade de articulação externa (MEC/CAPES) para viabilizar política pública de ação afirmativa transversal. 
São informações postas pela Universidade de Brasília, evidenciadas nas falas do quadro 8, 'Sistema de categorização (Analítico)', código: Dimensão I, Categoria Teórica 1, falas de ambos os entrevistados (E1, E2 e E3).

A estratégia da instituição resume-se em apoiar as iniciativas dos programas que têm autonomia para criarem o incentivo nas unidades acadêmicas, como ocorreu com a Antropologia, a Sociologia, o Direito e os Direitos Humanos e Cidadania. Porém, alguns ajustes são necessários para motivar a institucionalização de uma política de ação afirmativa na pós-graduação como a necessidade de políticas transversais interna e externamente à UnB, a necessidade de recursos para estender assistência estudantil para a pós-graduação e a ausência de lei que obrigue a implantação por parte do governo.

A inexistência de uma política pública de ação afirmativa para a população negra na pós-graduação stricto sensu, institucionalizada pelo governo, contribui para manutenção do resultado apresentado pelo relatório 'Mestres 2012: estudo da demografia da base técnicocientífica brasileira', do Centro de Gestão e Estudos Estratégicos (CGEE). Nele, é demonstrado o espantoso número que constata a pequena representação de negros mestres e doutores.

A população de mestres e doutores é muito mais branca do que a população como um todo. Os brancos correspondiam a 47\% da população residente no Brasil no ano de 2010, mas sua participação chegava a cerca de $80 \%$ da população de residentes cujo nível mais elevado de instrução era o mestrado e o doutorado. Em compensação, os pardos, que representavam $42 \%$ da população total, alcançavam apenas $16 \%$ da população de mestres, e $12 \%$ da de doutores. E os negros, cerca de $8 \%$ da população total, representavam apenas $3 \%$ dos mestres e $2 \%$ dos doutores (CGEE, 2012. p. 22).

Esses dados mostram que as ações afirmativas sugerem que as desigualdades sociais influenciam o número de mestres e doutores negros no Brasil. Revela-se uma relação inversamente proporcional ao percentual de brancos/negros encontrados na população, segundo o censo de 2010, do Instituto Brasileiro de Geografia e Estatística (IBGE, 2015).

No relatório de análise do sistema de cotas da graduação da Universidade de Brasília foi realizada uma pesquisa com uma amostra de cotistas egressos, para conhecer a 
situação deles com relação à pós-graduação. No resultado apresentado, verifica-se que 57\%, ou seja, a maior parte dos cotistas não havia feito, nem estava cursando algum curso de pósgraduação. A pesquisa revela, ainda, que $26 \%$ fez ou estava fazendo especialização, e $15 \%$ cursou ou estava cursando mestrado, 1\% doutorado e 1\% aperfeiçoamento (UNB, 2013, p. $34)$.

Essa perspectiva mostra que existe um potencial de estudantes da própria universidade que poderiam impactar em aumento dos percentuais no mestrado e doutorado, se houvesse ação afirmativa na pós-graduação. Segundo as entrevistas semiestruturadas realizadas com membros da gestão da universidade, o entrevistado E3 afirma que a existência de reserva de vagas atrai esse público tanto da UnB quanto de fora dela, porque faz com que se sintam menos intimidados para participarem de processos seletivos.

$\mathrm{Na}$ perspectiva de gestão pública, o governo sinalizou compactuar com essa tendência, quando o Ministério da Educação estipulou a estratégia 14.5, por meio do Plano Nacional de Educação, lei n. ${ }^{\circ}$ 13.005, de Junho de 2014, que diz:

\footnotetext{
Meta 14: elevar gradualmente o número de matrículas na pós-graduação stricto sensu, de modo a atingir a titulação anual de 60.000 (sessenta mil) mestres e 25.000 (vinte e cinco mil) doutores;

14.5) implementar ações para reduzir as desigualdades étnico-raciais e regionais e para favorecer o acesso das populações do campo e das comunidades indígenas e quilombolas a programas de mestrado e doutorado (PNE, 2014).
}

A ação pode ser considerada um incentivo à implantação de ações afirmativas em programas de pós-graduação stricto sensu. Porém, essa lei não especifica como as universidades devem contribuir para o alcance da meta, não obrigando a adoção de ações afirmativas. Essa decisão fica a cargo da autonomia universitária, garantida pela Constituição Federal, Art. 207 (CF, 1998). Esse fato é confirmado na fala do entrevistado E1, ao afirmar que a autonomia universitária da abertura para escolher quem pode ingressar ou não na universidade não é o governo que vai determinar. $\mathrm{O}$ entrevistado E3 pondera que essa autonomia é relativa, haja visto que a universidade serve para responder às demandas que a sociedade coloca para ela. 


\section{- Categoria Final 2: Implantações e Desdobramentos}

Essa categoria final, ligada à categoria teórica - 'Boas Práticas', na 'Dimensão Histórica' - foi desenvolvida a partir do objetivo específico 2, a saber: descrever/caracterizar as boas práticas das políticas de ações afirmativas em programas de pós-graduação stricto sensu. Trata-se de uma visão de políticas públicas de ação afirmativa na pós-graduação, incluindo a UnB que figura entre as pioneiras dessa prática.

As categorias intermediárias que sugerem a categoria final são: 1 - primeiras iniciativas da UnB nos cursos Antropologia, Sociologia, Direito e Direitos Humanos e Cidadania; 2 - DAC estuda estender auxílio financeiro à pós-graduação; 3 - associação de estudantes e demandas por um modelo institucional; 4 - fora da UnB, a UFRJ foi a primeira a implantar reserva de vagas na pós-gradutação, no curso de Antropologia Social, do Museu Nacional; 5 - a Sociologia da UnB prioriza bolsas de estudo e curso preparatório de inglês para a população negra e cotista; 6 - aparente qualidade igualitária entre cotistas e não cotistas. Os resultados da perspectiva de boas práticas estão na Dimensão I, Categoria Teórica 2, falas dos entrevistados (E1, E2 e E3), as quais podem ser lidas no quadro 'Sistema de Categorização (Analítico)' disponível no apêndice.

A UNEB é uma referência para esse objetivo específico. Embora seja da esfera estadual, ela implantou uma política de ação afirmativa para a população negra institucional e global, pois, desde sua concepção, abrangeu a graduação e a pós-graduação, e, todos os processos seletivos, de acordo com a Resolução 196, publicada no Diário Oficial, em 25 de Julho de 2002, a saber:

Art. $1^{\circ}$ - Estabelecer a quota mínima de $40 \%$ (quarenta por cento) para a população afrodescendente, oriunda de escolas públicas, no preenchimento das vagas relativas aos cursos de graduação e pós-graduação oferecidos pela Universidade do Estado da Bahia, UNEB, seja na forma de vestibular ou de qualquer outro processo seletivo (Resolução CONSU nº 196, 2002, p. 1)

De acordo com os dados levantados, tanto na análise de documento quanto nas entrevistas, constata-se que a Universidade de Brasília tem uma política de ação afirmativa consolidada na graduação, o que ocorreu no início desta década, com 10 anos de experiência, 
período no qual começa a acontecer um movimento de ampliação dessa prática para a pósgraduação stricto sensu. A UnB figura como pioneira no contexto nacional também dentre as universidades federais que avançam em políticas públicas de ações afirmativas, quando implanta em 2015 reserva de vagas em programas de pós-graduação stricto sensu.

A UFRJ é a primeira de todas as federais a implantar reserva das vagas no programa de pós-graduação em Antropologia Social, no Museu Nacional. E há outros exemplos que acompanharam essa tendência, com cursos sempre nas áreas de Antropologia, Sociologia, Direito e Direitos Humanos e Cidadania, confirmando a afirmação do entrevistado E1, de que são os cursos em humanidades que desbravam esse caminho (Cód.: II, 3, E1, 11).

A Sociologia prioriza disponibilizar bolsas de estudos para os cotistas interessados, como forma de suprir a lacuna existente pela falta de recursos para auxílio financeiro aos estudantes por parte do Decanato de Assuntos Comunitários, o que tem sido feito apenas para estudantes de graduação. Outra prática em seu modelo é a oferta de curso preparatório para a prova de proficiência em línguas, preferencialmente para candidatos à reserva de vagas.

Ainda não existem insumos que permitam a realização de uma avaliação para averiguar a qualidade dos cotistas, o que pode ser feito ao final de um ciclo de mestrado ou doutorado que se inicia em 2015. Contudo, baseados em observações de posturas, discussões e atividades desenvolvidas até então, a qualidade da turma de Sociologia é a mesma. A diferença notada é a existência de turma heterogênea, comprovando o caminho para a justiça racial.

Sob o prisma das experiências em ação afirmativa, na pós-graduação stricto sensu, pode-se destacar o que se vê no quadro a seguir.

Quadro 10 - Boas Práticas de Políticas de Ação Afirmativa em Programas de Pós-Graduação Stricto Sensu

\begin{tabular}{|l|l|l|}
\hline \multicolumn{1}{|c|}{ Instituição } & \multicolumn{1}{|c|}{ Implantada } & \multicolumn{1}{c|}{ Modelo } \\
\hline UNEB & 2003 & $\begin{array}{l}\text { Resolução 468/2007 Consu: } \\
\text { 40\% para candidatos negros; }\end{array}$ \\
$\begin{array}{l}\text { Todos } \\
\text { cursos }\end{array}$ & $\begin{array}{l}\text { Fonte: Resolução } \\
196 / 2002 \text { Consu }\end{array}$ & $\begin{array}{l}\text { Estão habilitados a concorrer às vagas reservadas } \\
\text { candidatos negros e candidatos indígenas que } \\
\text { preencham os seguintes requisitos: }\end{array}$ \\
\hline
\end{tabular}




\begin{tabular}{|c|c|c|}
\hline & & $\begin{array}{l}\text { a)Tenham cursado todo o ensino médio em escola } \\
\text { pública; } \\
\text { b) tenha renda familiar mensal inferior ou igual a } 10 \\
\text { (dez) salários mínimos; e } \\
\text { c) sejam e declarem-se negro ou indígena, conforme } \\
\text { quadro de autoclassificação étnico-racial constante da } \\
\text { ficha de inscrição do respectivo processo seletivo. }\end{array}$ \\
\hline $\begin{array}{l}\text { UFRJ } \\
\text { Programa de } \\
\text { Pós- } \\
\text { Graduação em } \\
\text { Antropologia } \\
\text { Social do } \\
\text { Museu } \\
\text { Nacional }\end{array}$ & $\begin{array}{l}2014 \\
\text { Fonte: } \\
\text { Edital } 48 / 2914 \\
\text { Mestrado } \\
\text { Edital } 49 / 2014 \\
\text { Doutorado }\end{array}$ & $\begin{array}{l}\text { Política ao acesso Afirmativo ao PPGAS/MN/UFRJ: } \\
\text { - Reserva de } 20 \% \text {; } \\
\text { - Nota de corte 5,0 para negros em todas as etapas } \\
\text { (sendo 7,0 para não negros); } \\
\text { - Auto-declaração voluntária no momento da } \\
\text { inscrição, por meio do preenchimento de } \\
\text { formulário próprio; }\end{array}$ \\
\hline $\begin{array}{l}\text { UnB } \\
\text { Programa de } \\
\text { Pós- } \\
\text { Graduação em } \\
\text { Sociologia }\end{array}$ & $\begin{array}{l}2014 \\
\text { Fonte: } \\
\text { Edital Mestrado/ } \\
\text { Doutorado } \\
\text { Sociologia } 1 / 2015\end{array}$ & $\begin{array}{l}\text { Programa de Ações Afirmativas PPGSol: } \\
\text { - Reserva de } 25 \% \text { para mestrado e } 21 \% \text { para } \\
\text { doutorado acadêmico; } \\
\text { - Note de corte diminuiu para todos os inscritos; } \\
\text { - Auto-declaração voluntária no momento da } \\
\text { inscrição, por meio do preenchimento de } \\
\text { formulário próprio; } \\
\text { - Considerados/as negros ou negras candidatos/as } \\
\text { socialmente reconhecidos/as como tal e } \\
\text { incluídos/as nas categorias de pretos e pardos, } \\
\text { segundo a classificação IBGE; } \\
\text { Curso preparatório para prova de inglês } \\
\text { preferencialmente para os candidatos negros. }\end{array}$ \\
\hline $\begin{array}{l}\text { UnB } \\
\text { Programa de } \\
\text { Pós- } \\
\text { Graduação em } \\
\text { Antropologia }\end{array}$ & $\begin{array}{l}2014 \\
\text { Fonte: } \\
\text { Edital Mestrado } \\
\text { Antropologia } \\
3 / 2014 \\
\text { Edital Doutorado } \\
\text { 4/2014 }\end{array}$ & $\begin{array}{l}\text { Programa de Ação afirmativa do PPGAS-UnB } \\
\text { - Reserva de } 20 \% \text { para mestrado acadêmico e } 20 \% \\
\text { para doutorado; } \\
\text { - Auto-declaração voluntária no momento da } \\
\text { inscrição por meio do preenchimento de } \\
\text { formulário próprio; } \\
\text { - Prioridade no programa de bolsas do PPGAS-UnB } \\
\text { para esse público }\end{array}$ \\
\hline $\begin{array}{l}\text { UnB } \\
\text { Programa de } \\
\text { Pós- } \\
\text { Graduação em } \\
\text { Direitos } \\
\text { Humanos }\end{array}$ & $\begin{array}{l}2015 \\
\text { Fonte: } \\
\text { Edital 1/2015 }\end{array}$ & $\begin{array}{l}\text { Programa de Ação afirmativa do PPGDHC-UnB } \\
\text { - Reserva de } 25 \% \text { para mestrado acadêmico; } \\
\text { - Auto-declaração voluntária no momento da } \\
\text { inscrição, por meio do preenchimento de } \\
\text { formulário próprio; } \\
\text { - Canditados/as negros/as que sejam socialmente } \\
\text { reconhecidos/as como tais; } \\
\text { O candidato com nota com valor entre a nota de } \\
\text { corte da lista sem ser a reserva de vagas passa a } \\
\text { concorrer na lista geral. A vaga inicial dele vai }\end{array}$ \\
\hline
\end{tabular}




\begin{tabular}{|l|l|l|}
\hline & & $\begin{array}{l}\text { para o candidato subsequente da reserva de vagas; } \\
\text { Prioridade no programa de bolsas do PPGDHC- } \\
\text { UnB para esse público }\end{array}$ \\
\hline $\begin{array}{l}\text { PnB } \\
\text { programa de no } \\
\text { bolsas do } \\
\text { PPGD-UnB }\end{array}$ & $\begin{array}{l}\text { Fonte: } \\
\text { Edital Mestrado } \\
\text { Direitos 1/2016 }\end{array}$ & $\begin{array}{l}\text { Ingresso por meio da modalidade de reserva de vagas } \\
\text { para candidato(a)s negro(a)s: } \\
\text { Reserva de 20\% para mestrado e 20\% para } \\
\text { doutorado acadêmico; } \\
\text { Negro(a), de cor preta ou parda, conforme normas } \\
\text { internas das Políticas de Ação Afirmativa da UnB. }\end{array}$ \\
\hline
\end{tabular}

\section{- Categoria Final 3: Institucionalização}

Esta categoria final, ligada à categoria teórica - 'Ações Afirmativas de PósGraduação Stricto Sensu', na 'Dimensão Ações Afirmativas', foi desenvolvida a partir do objetivo específico 3 - "descrever as ações afirmativas adotadas na Universidade de Brasília para acesso de negros a cursos de pós-graduação stricto sensu, no período de 2004 a 2015”, e se refere a uma visão sob a perspectiva de institucionalização de políticas públicas com aprofundamento na Universidade de Brasília.

Além dessas informações, obtidas por meio da análise documental, as entrevistas semiestruturadas trouxeram elementos que confirmam essa tendência à institucionalização política de ação afirmativa de estímulo ao acesso de negros à pós-graduação stricto sensu, de forma institucional. São falas dos entrevistados, traduzidas (significados) em pressões pelo estabelecimento de uma política pública, as quais definiram as seguintes categorias intermediárias: 1 - sem estudos e pretensão do DPP em estabelecer uma política institucional de ação afirmativa; 2 - sem impeditivos institucionais para os cursos implantarem de forma isolada nas unidades acadêmicas; 3 - pressão dos estudantes, das unidades acadêmicas e do DAC para uma política de ação afirmativa institucional; 4 - meta do governo (14.5 do PNE) como estímulo à institucionalização de uma política de ação afirmativa na pós; 5 - falta de recurso para auxílio financeiro aos estudantes da pós-graduação e possível resistências de alguns são impeditivos atuais para uma política institucional de ação afirmativa na pósgraduação; 7 - após a consolidação na graduação, a tendência é de institucionalizar uma 
política de ação afirmativa na pós-graduação. As falas podem ser lidas no quadro 'Sistema de Categorização (Analítico)', código II, 3, E1-E2-E3.

As forças convergentes para implantação da referida política são: estudantes que pressionam as unidades acadêmicas, as universidades e o governo; unidades acadêmicas que pressionam as universidades e o governo; universidades que pressionam o governo; governo que pressiona as universidades; a sociedade que pressiona o governo. A figura abaixo ilustra essa demanda latente que visa ao alcance do mesmo objetivo.

Figura 7 - Pressão para Política Pública de Ação Afirmativa na Pós-Graduação Stricto Sensu

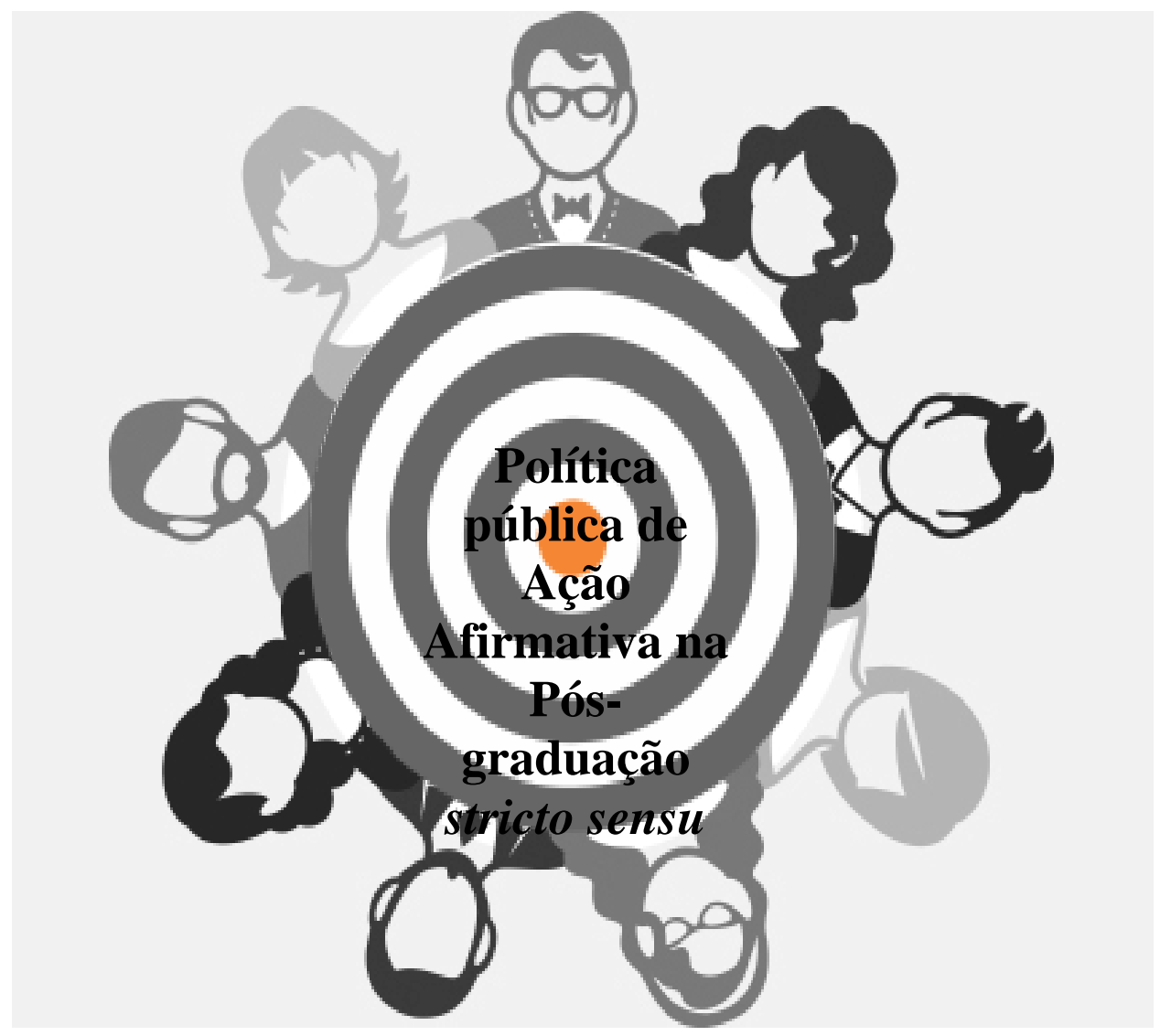

A suposição de que a UnB pouco tem se esforçado institucionalmente para atender às demandas por uma política pública de ação afirmativa que estimule a ampliação ao acesso da população a cursos de pós-graduação stricto sensu é confirmada. É possível perceber uma tendência à manutenção da conduta atual por parte da Universidade de Brasília. 
Constata-se um momento de início de aumento da pressão por diversos lados para a institucionalização de uma política pública de ação afirmativa para ampliação ao acesso da população negra a cursos de pós-graduação stricto sensu obervada nesta década.

A entrevistada E2 menciona que o fórum de pró-reitores de assuntos comunitários é favorável a essa política, mas com dinheiro novo. Esse assunto está na agenda do fórum junto a ANDIFES. A meta 14.5, do Plano Nacional de Educação estipuladada pelo governo, sinaliza um início de diretriz para esse tema.

Os estudantes, historicamente, se movimentam para pressionar melhorias ao acesso e permanência de negros no ensino superior. Recentemente a Associação Nacional de Pós-Graduandos, que existe desde 1986, priorizou a discussão sobre a necessidade de se haver ações afirmativas no I Fórum de Representantes Discentes dos Programas de Pós-Graduação da UnB (ANPG, 2015).

O entrevistado E3 afirma haver uma organização entre estudantes negros, de alguns coletivos que militam em DCE, etc. Essa organização encoraja um engajamento com a causa que transforma a participação em ação afirmativa, uma questão ligada à sua própria autoestima, sua própria identidade. No Instituto de Ciências Sociais, esse grupo se mobiliza para manter a conquista.

Esse conjunto de forças é significativo e provoca uma pressão que direciona para a ampliação da política de ação afirmativa para a pós-graduação stricto sensu.

No entanto, as forças divergentes também deverão ser consideraras. Os entrevistados sinalizaram que o modelo de avaliação da CAPES não contempla essa questão, tornando-se um inibidor de adoção de ação afirmativa por receio, infundado, de impactar nas notas dos cursos. O entrevistado E3 sugere que os programas de pós-graduação, que tenham reservas de vagas, sejam pontuados por isso, estimulando, assim, outros cursos a implantarem a política (Cód. II, 1, E3, 25).

Outro ponto a ser considerado é a possível resistência que os cursos, declaradamente conservadores, apresentam, se opondo a influências das instâncias colegiadas nas aprovações da política institucional. 
Além disso, o fato de inexistir recurso disponibilizado pelo governo para ajuda financeira a estudantes de pós-graduação stricto sensu impossibilita o DAC a estender a política de assistência estudantil para esse público, o qual presume-se ter desvantagens socioeconômicas.

Esses são exemplos de forças que atuam contra a extensão da ação afirmativa da graduação para a pós-graduação stricto sensu na Universidade de Brasília, e, de forças que atuam formando uma pressão para a institucionalização de uma política de ação afirmativa para acesso da população negra à pós-graduação stricto sensu.

\section{- Categoria Final 4: Questões que Transpõem o Ingresso}

Esta categoria final, ligada à categoria teórica - 'Acesso' na 'Dimensão Ações Afirmativas' -, foi desenvolvida a partir do objetivo específico 4 - identificar as dificuldades ao acesso da população negra aos Programas de Pós-graduação stricto sensu ofertados pela Universidade de Brasília sob a perspectiva da instituição. Trata-se de uma visão sob a perspectiva de formas ou barreiras da população negra entrar, acessar e ingressar em cursos de pós-graduação stricto sensu com aprofundamento na Universidade de Brasília.

Alguns pontos se referem ao acesso da população negra aos programas de pósgraduação stricto sensu da Universidade de Brasília. As falas dos entrevistados resultaram na categoria intermediária: 1 - demanda por vaga diferente de acordo com a natureza do curso e concorrência; 2 - necessidade de política de assistência estudantil como complementar ao estímulo ao acesso; 3 - instrumento de seleção que promova real igualdade de oportunidades; 4 - processos seletivos não intimidadores; 5 - condições de profunda desigualdade dificultam recrutar negros para as seleções; 6 - a existência de edital com reserva de vagas estimula por encorajar. As falas podem ser verificadas no quadro 'Sistema de categorização (Analítico)', nos códigos II, 4, E1 a E3.

O entrevistado E1, Cód. I,1, E1, contribui expondo o entendimento dos motivos principais que induzem a inexistência dessa política por parte da instituição. Segundo ele, em alguns cursos, os mais técnicos como Biologia Molecular, não há concorrência o para 
justificar uma reserva de vagas. Em cursos de 'humanidades' existe a concorrência como barreira para o acesso, então até se justifica.

A entrevistada E2 contribui com o posicionamento institucional quando coloca a questão da falta de recursos para assistência estudantil. Parte-se do pressuposto de que o público negro é desprovido financeiramente e a assistência estudantil restringi-se à graduação, dificultando a permanência do cotista de pós-graduação, fato que pode desestimular a participação nos processos seletivos.

Todavia, o entendimento do entrevistado E3 é de que as barreiras para acesso à pós-graduação vão além desses motivos, e estão ligadas às questões de falta de autoestima por parte da população negra. Para ele, a reserva de vagas para essa população ameniza esses fatores. No entanto, os processos seletivos não costumam ser feitos de forma a quebrar essas barreiras, sendo, na verdade, intimidadores. Sendo assim, faz-se necessário pensar em instrumentos de seleção (editais) que promovam real igualdade de oportunidades. Para tanto, é preciso olhar para a política de assistência estudantil como complementar ao estímulo ao acesso, pois as condições de profunda desigualdade dificultam recrutar negros para as seleções. A existência de edital com reserva de vagas estimula e encoraja por uma questão de identidade, desde que primados os cuidados aqui expostos. 


\section{CONSIDERAÇÕES FINAIS}

De acordo com o observado por meio da análise documental e das entrevistas, alicerçado pela revisão da literatura, é possível considerar que as ações afirmativas ao acesso da população negra ao ensino superior estão consolidadas sob a perspectiva do ensino superior brasileiro. Tal resultado é reflexo de toda uma luta secular, do reconhecimento dessa lacuna social e de todo um conhecimento acumulado acerca dos aspectos que circundam o tema. Essa lacuna é campo de atuação de políticas públicas, como esclarecem Rua (1998) e Santos et al (2008), e "que rompe radicalmente com a lógica de funcionamento do mundo acadêmico brasileiro desde a sua origem no início do século passado" (CARVALHO, 2006, p. $01)$.

Existem inúmeras contribuições jurídicas, mas algumas conferiram grande relevância para mudar o cenário das ações afirmativas no Brasil. A Declaração Internacional de Direitos Humanos (1948) projeta a questão da igualdade entre raças no cenário mundial e inclui o tema nas agendas políticas dos países. A Declaração de Durban (2001) teve um papel fundamental ao revelar a existência do racismo no Brasil, velado pela academia, como afirma Carvalho (2007), momento no qual não mais seria possível negar a reparação à população negra sob diversas questões sociais, entre elas a educação superior.

Os estados saíram na frente da União nessas respostas, com implantações de ações afirmativas nas universidades estaduais. Foi na esfera estadual que surgiram os pioneiros na adoção de ações afirmativas ao acesso da população negra ao Ensino Superior brasileiro, no modelo de sistema de cotas ou reserva de vagas: a UNEB, em 2002, e a UERJ e a UEMS, em 2003. Porém foi na esfera federal que esse tema ganhou visibilidade com a reconhecida contribuição da UnB, a pioneira nesse âmbito, a qual implantou a ação afirmativa no mesmo modelo das pioneiras estaduais - o sistema de cotas amplamente adotado. Em 2009, a UFMG inova, implantando o Sistema de Bônus, que ao invés de reservar vagas para os negros, adiciona pontuação extra nos resultados das seleções desse público.

As ações afirmativas na graduação foram incorporadas por meio de políticas 
públicas institucionalizadas primeiramente pelas universidades e depois pelo governo, por força de lei. Uma prática mais avançada nesse cenário é verificada na universidade UNEB que incluiu a pós-graduação stricto sensu desde a implantação da política pública, de forma institucional, aprovada em 2002.

O governo passou a demandar das Instituições de Ensino Superior o estímulo ao acesso da população negra à pós-graduação stricto sensu, quando aprovou o Plano Nacional de Educação (PNE) em 2014, com a - meta 14 - com o objetivo de "elevar gradualmente o número de matrículas na pós-graduação stricto sensu, de modo a atingir a titulação anual de 60.000 (sessenta mil) mestres e 25.000 (vinte e cinco mil) doutores", considerando atingir a meta, agregando grupos discriminados, incluindo a população negra, étnico-racial na estratégia. A meta 14.5 propõe "implementar ações para reduzir as desigualdades étnicoraciais e regionais, para favorecer o acesso das populações do campo e das comunidades indígenas e quilombolas a programas de mestrado e doutorado". Como as universidades contribuirão para essa meta não está vinculado a ações afirmativas pelo PNE/2014. Dessa forma, trata-se de um estímulo, mas não de uma obrigação às IES a implantação de ações afirmativas de forma institucional na pós-graduação stricto sensu, como ocorre com a graduação, consequência da Lei das Cotas 12.711/2012. Porém, há a sinalização de intenção do governo em incentivar o aumento do número de negros mestres e doutores.

A Universidade de Brasília, sob a perspectiva da instituição, tem uma postura omissa com relação à ampliação da política afirmativa para a pós-graduação stricto sensu. Pode-se dizer que essa seja a sua política. Por outro lado, as unidades acadêmicas que tratam assuntos relacionados a desigualdades sociais e, portanto, que têm conhecimento da causa, começam a se mobilizar e a usar de sua autonomia para implantar reservas de vagas em programas de pós-graduação, como no caso da Antropologia, da Sociologia, do Direito e do Direitos Humanos e Cidadania. No cenário da educação superior são verificados os mesmo movimentos, o que revela ser uma tendência.

O posicionamento da Universidade de Brasília segue o regulamentado pela Resolução n. ${ }^{\circ}$ 91/2004, aprovada pelo Conselho de Ensino, Pesquisa e Extensão da instituição. Nele não há determinação para os cursos adotarem reserva de vagas para a população negra. Ou seja, a UnB, enquanto instituição, não tem política de ação afirmativa na pós-graduação stricto sensu. A estratégia da instituição resume-se em apoiar as iniciativas dos 
programas que têm autonomia para criarem o incentivo nas unidades acadêmicas, como ocorreu com a Antropologia, a Sociologia, o Direito e os Direitos Humanos e Cidadania.

Existem forças convergentes significativas que exercem uma pressão para a implantação de uma política institucional sobre as universidades e o governo, como sociedade, estudantes, universidades, governo - contribuindo para essa discussão. Em consequência, surgem lacunas para as quais se faz necessário mudanças, para ajustes necessários, que visem motivar a institucionalização de uma política de ação afirmativa na pós-graduação, como a necessidade de políticas transversais interna e externamente à UnB, como a necessidade de recursos para estender assistência estudantil para a pós-graduação, pois não há lei que obrigue a implantação por parte do governo e a avaliação da CAPES/MEC, pois não contemplam essa questão. Para isso, faz-se necessária a atuação do governo, sob a perspectiva de gestão pública, para articular os setores necessários a fim de desenhar uma política de ação afirmativa para a pós-graduação, que possa, de fato, representar um estímulo ao acesso às universidades públicas.

Os dados da pesquisa apontam duas perspectivas para responder à questão da pesquisa, a saber: a ampliação ao acesso da população negra nos cursos de pós-graduação stricto sensu da Universidade de Brasília tem atendido às demandas das pressões sócias?) 1) Da instituição UnB que corresponde a gestão da administração superior, representadas pelo DPP e DAC: O DPP, área diretamente responsável por essa política, e, DAC, que subsidia de forma integrada esse tipo de ação. A primeira área não criou uma política de ação afirmativa de forma institucional que abrangesse todos os cursos, e, não fomenta discussões sobre o assunto. Sua atuação é omissa e se limita a prestar o apoio dentro da legalidade e dos procedimentos pertinentes às unidades acadêmicas que queiram implantar, usando de suas autonomias expressas no regulamento. A segunda, fomenta a discussão dos Fóruns Nacionais de Pró-reitores de Assuntos Comunitários e Estudantis (FONAPRACE) os quais participam. Ambos apoiam os estudantes, principalmente organizados em forma de associação - nacional (ANPG) e da UnB (APG) - de pós-graduandos. 2) Das ações isoladas por parte das unidades acadêmicas que têm autonomia para propor critérios ao acesso, garantida pela Resolução CEPE 91/2004. Na UnB, as unidades acadêmicas que implantaram a ação afirmativa, no modelo de reserva de vagas, foram o Instituto de Ciências Sociais (ICS), nos cursos de Sociologia e a Antropologia Social, a Faculdade de Direto, curso de Direito, e o Centro de Estudos Avançados Multidisciplinares, no curso de Direitos Humanos e Cidadania. Segue o 
observado nas IFES de ter iniciativas das unidades acadêmicas dos cursos de ciências humanas, os quais têm afinidade e discutem o tema. Elas saíram na frente da instituição a fim de responder às demandas da lacuna social em questão.

Diante do exposto, os dados da pesquisa sugerem que a Universidade de Brasília tem sido omissa no esforço para atender às demandas por uma política pública de ação afirmativa que estimule a ampliação ao acesso da população negra a cursos de pós-graduação stricto sensu. Constata-se isso pelo fato de apenas 04 (quatro) de seus 94 (noventa e quatro) programas de pós-graduação em funcionamento (CAPES, 2016), ou seja, 4,2\%, ter reserva de vagas, o que ocorreu por iniciativa dos próprios programas de pó-graduação, os quais discutem o tema pela natureza dos cursos. Além disso, na fala do DPP fica intrínseca a estratégia de não se mobilizar nesse sentido de institucionalizar a prática.

Tendo em vista o quadro apresentado, sob a perspectiva acadêmica, são recomendados alguns estudos para que haja um avanço nas discussões: a Universidade de Brasília poderia realizar estudos integrando o Decanato de Pesquisa e Pós-graduação, o Decanato de Assuntos Comunitários às unidades acadêmicas, aos estudantes, a fim de analisar a viabilidade de uma política de ação afirmativa de estímulo ao acesso da população negra na pós-graduação stricto sensu, à luz da teoria da institucionalização; um modelo de instrumento de seleção a ser adotado poderia ser analisado, que fosse efetivo no atendimento da sua finalidade, que é o acesso de negros em mestrados e doutorados, considerando-se fatores diversos, como a existência de processos seletivos verdadeiramente atrativos que considerassem as questões intrínsecas sociais; bem como, podem ser desenvolvidos estudos que avaliem os resultados e impactos das turmas que têm reserva de vagas após conclusão da pós-graduação para se verificar, por exemplo, se afetou a qualidade dos cursos, ao final do ciclo das turmas em andamento nas universidades, entre outros aspectos.

Sob a perspectiva da instituição, recomenda-se: propor a implantação de uma política de ação afirmativa de estímulo ao acesso de negros na pós-graduação stricto sensu de forma institucional; promover debates sobre esse assunto no meio acadêmico (fóruns de reitores e pró-reitores), no MEC, e em outras reuniões pertinentes, para mostrar um posicionamento favorável à ampliação do sistema de cotas para a pós-graduação stricto sensu, reafirmando, assim, sua conduta de vanguarda no tema; dialogar com o governo, a fim de angariar recursos para subsidiar a política de permanecia na pós-graduação stricto sensu; e 
buscar o desafio do envolvimento da CAPES, para rever sua forma de avaliar os programas de pós-graduação, de forma a considerar a existência de ações afirmativas. Pode-se, ainda, realizar ações de conscientização junto às instituições conveniadas à UnB que oferecem vagas de estágios. Dessa forma, a Universidade de Brasília confirmaria seu comportamento de vanguarda. 


\section{REFERÊNCIAS}

ALYRIO, Rovigati Danilo. Métodos e técnicas de pesquisa em administração. Rio de Janeiro: Fundação CECIERJ, 2009.

ANDIFES. Associação Nacional dos Dirigentes das Instituições Federais de Ensino Superior. Universidades públicas aumentam uso de cotas para negros e índios na pós-graduação. Disponível em: <http://www.andifes.org.br/universidades-publicas-aumentam-uso-de-cotaspara-negros-e-indios-na-pos-graduacao>. Acesso em 25 de Novembro de 2015.

BAHIA. Universidade do Estado da Bahia. Ex-reitora é homenageada por pioneirismo na implantação do sistema de cotas. Disponível no sítio: <http://www.uneb.br/2012/11/06/exreitora-ivete-sacramento-foi-homenageada-na-casa-do-comercio>. Acesso em: 05 de Novembro de 2014.

BARRETO, Paula. Apoio à permanência de estudantes de escolas públicas e negros em universidades públicas brasileiras: as experiências dos projetos Tutoria e Brasil Afroatitude. In: BRANDÃO, André Augusto (Org.). Cotas Raciais no Brasil: uma primeira avaliação. Rio de Janeiro: DP\&A, 2007.

BRASIL. Constituição (1988). Constituição da República Federativa do Brasil. Brasília, DF: Senado Federal: Centro Gráfico, 1988.

Ministério da Educação. Coordenação de Aperfeiçoamento de Pessoal de Nível Superior. História e Missão. Disponível no sítio: < http://www.capes.gov.br/historia-emissao>. Acesso em 25 de Novembro de 2014.

Ministério da Educação. Coordenação de Aperfeiçoamento de Pessoal de Nível Superior. Cursos Recomendados/Reconhecidos.. Disponível no sítio: <http://www.capes.gov.br/cursos-recomendados>. Acesso em 25 Nov 2014.

Ministério da Educação. Coordenação de Aperfeiçoamento de Pessoal de Nível Superior. Plataforma Sucupira. Dados Cadastrais do Programa. Disponível no sítio: https://sucupira.capes.gov.br/sucupira/public/consultas/coleta/programa/listaPrograma.jsf> Acesso em 02 de Janeiro de 2016.

Ministério da Educação. Coordenação de Aperfeiçoamento de Pessoal de Nível Superior. Sobre avaliação. Disponível no sítio: <http://www.capes.gov.br/avaliacao/sobre-aavaliacao>. Acesso em 25 de Novembro de 2014.

Ministério da Educação. Coordenação de Aperfeiçoamento de Pessoal de Nível Superior. Plano Nacional de Pós-graduação - PNPG 2011-2020. Brasília. CAPES, 2010.

Ministério da Educação. Ações Afirmativas (Cotas/Prouni). Disponível no sítio: $<$ http://etnicoracial.mec.gov.br/acoes-afirmativas-cotas-prouni>. Acesso em 11 de Dezembro de 2014. 
no sítio: < http://etnicoracial.mec.gov.br/images/pdf/declaracao_durban.pdf>. Acesso em 13 de Dezembro de 2014.

- Ministério da Educação. Educação para as relações ético-raciais: Ações Afirmativas (Cotas/Prouni). Disponível no sítio: <http://etnicoracial.mec.gov.br/acoesafirmativas-cotas-prouni>. Acesso em 11 de Dezembro de 2014.

Ministério da Educação. Instituto Nacional de Estudos e Pesquisas Educacionais Anísio Teixeira Resultados do Censo da Educação Superior 2013. Brasília, DF: INEP, 2013.

Ministério da Educação. Programas e Ações. Disponível no sítio: $<$ http://portal.mec.gov.br/index.php?option=com_content\&view=article\&id=12498\&Itemid= 820>. Acesso em 25 de agosto de 2015.

BRASIL. Ministério da Educação e Cultura. Documento. Parecer CFE no 977/65, aprovado em 3 dez. 1965. Definição dos cursos de pós-graduação. Rev. Bras. Educ. $n^{a} 30$ Rio de Janeiro Sept./Dec. 2005

BRASIL. Ministério do Planejamento, Orçamento e Gestão. Secretaria de Planejamento e Investimentos Estratégicos. Relatório de Comunicação à Comissão Mista de Planos, Orçamentos Públicos e Fiscalização do Congresso Nacional (CMO). Alterações do Plano Plurianual 2012-2015. Brasília - DF, Julho de 2013.

Câmara dos Deputados Documento de Referência do PNE. Plano Nacional de Educação (PNE).2014-2024: Lei n. ${ }^{\circ}$ 13.005, de 25 de junho de 2014, que aprova o Plano Nacional de Educação (PNE) e dá outras providências. - Brasília: Câmara dos Deputados, Edições Câmara, 2014.

Ministério do Planejamento, Orçamento e Gestão. Secretaria de Planejamento e Investimentos Estratégicos. Faces da desigualdade de gênero e raça no Brasil. Brasília: IPEA, 2011.

Ministério do Planejamento, Orçamento e Gestão. Secretaria de Planejamento e Investimentos Estratégicos. O sistema classificatóriode "cor ou raça" do IBGE. ISSN 1415-4765. Texto para discussão no 996. Brasília: IPEA, 2003. Disponível em < http:// http://www.ipea.gov.br/portal/images/stories/PDFs/TDs/td_0996.pdf> Acesso em: 16.out 2015 .

Presidência da República. Lei 13.005 de 25 de junho de 2014. Disponível no sítio: <http://www.planalto.gov.br/ccivil_03/_ato2011-2014/2014/lei/113005.htm>. Acesso em 16 Out 2015.

Portal Brasil. Capes recomenta 574 opções de cursos de mestrado profissional. Disponível no sítio: <http://www.brasil.gov.br/educacao/2014/05/capes-recomenda-574opcoes-de-cursos-de-mestrado-profissional> . Acesso em de 25 Novembro de 2014.

Portal Brasil. Saiba como funciona sistema de ensino superior no Brasil

Disponível no sítio: < http://www.brasil.gov.br/educacao/2009/11/ensino-superior>. Acesso em 24 de Agosto de 2015. 
. Secretaria de Políticas para as Mulheres. Programa de Gestão de Políticas Públicas em Gênero e Raça. Rio de Janeiro: CEPESC; Brasília: Secretaria de Políticas para as Mulheres, 2011.

Secretaria de Políticas para as Mulheres. Brasília Plano Nacional de Políticas para Mulheres. Secretaria de Políticas para Mulheres, 2013.

. SEPPIR. O que são Ações Afirmativas. Disponível no sítio: < http://www.seppir.gov.br/assuntos/o-que-sao-acoes-afirmativas > Acesso em 16 de Outubro de 2014.

SEPPIR. O ministério. Disponível no sítio: < http://www.seppir.gov.br/sobre-aseppir/o-ministerio>. Acesso em 16 de Outubro de 2015.

. SEPPIR. "Mulheres, juventude e comunidades tradicionais continuam sendo prioritários", afirma novo secretário. Disponível no sítio: < http://www.seppir.gov.br/central-de-conteudos/noticias/201 cmulheres-juventude-e-

comunidades-tradicionais-continuam-sendo-prioritarios201d-afirma-novo-secretario> Acesso em 29 de Dezembro de 2015.

BORGES, Maria Creusa de. SANTOS, Thiago Rodrigo Fernandes da Silva. O acesso à educação superior brasileira: a adoção das cotas sociais - mapeando as discussões no supremo tribunal federal. Seminário/ANPAE, 2012.

CARVALHO, José Jorge de. As propostas de cotas para negros e o racismo acadêmico no Brasil. Sociedade e Cultura, v. 4, n. 2, , p. 13-30. jul./dez. 2007.

CARVALHO, José Jorge de. O confinamento racial do mundo acadêmico brasileiro. Revista USP, São Paulo, n. 68, p. 88-103, dezembro/fevereiro 2005-2006.

CGEE. Centro de Gestão e Estudos Estratégicos. Mestres 2012: Estudos da demografia da base técnico-científica brasileira. Brasília, DF: Centro de Gestão e Estudos Estratégicos, 2012.

CONTINS, Marcia. SANT'ANA, Luiz Carlos. O movimento negro e a questão da ação afirmativa. Estudos Feministas n.4, p. 209-220, 1996.

CURY, Carlos Roberto Jamil. Quadragésimo ano do parecer CFE no 977/65. Revista Brasileira de Educação. N. 30, set /out /nov /dez, 2005.

HAIR JR., JOSEPH F. Fundamentos de Métodos de Pesquisa em Administração. Joseph F. Hair Jr, Barry Babin, Arthur H. Money e Phiilip Samuel (Orgs.). Porto Alegre: Bookman, 2005.

ONU. Declaração Universal dos Direitos Humanos. Organização das Nações Unidas. 1948.

PEIXOTO, Maria do Carmo de Lacerda. BRAGA, Mauro Mendes. Ações afirmativas no ensino superior e o programa de bônus para ingresso nos cursos de graduação da Universidade Federal de Minas Gerais. Revista Brasileira Estudos Pedagógicos (RBEP), Brasília, v. 93, n. 233, p. 166-188, jan./abr. 2012. 
REVISTA FORUM. Mesmo com Nilma Gomes ministra da Cidadania, extinção da Seppir é retrocesso. Disponível no sítio: <http://www.revistaforum.com.br/quilombo/2015/10/02/mesmo-com-nilma-gomes-ministrada-cidadania-extincao-da-seppir-e-retrocesso/> Acesso em 29 de Dezembro de 2015.

RIBEIRO, Renato Janine. O mestrado profissional na política atual da Capes. Revista Brasileira de Pós-graduação - RBPG/CAPES. v. 2, n. 4, p. 8-15, jul. 2005.

RUA, Maria Graça. Análise de Políticas Públicas: Conceitos básicos. In: RUA, G. \& CARVALHO, M.I.V (Org.). O estudo da política: tópicos selecionados. Brasília: Paralelo $15,1998$.

SANTOS, Sales Augusto dos. CAVALlEIRO, Eliane. BARBOSA, Maria Inês da Silva. RIBEIRO Matilde. Ações afirmativas: polêmicas e possibilidades sobre igualdade racial e o papel do estado. Revista Estudos Feministas. v.16, n.3, p. 913-929, 2008-12.

SANTOS, A. P. Itinerário das ações afirmativas no ensino superior público brasileiro: dos ecos de Durban à Lei das Cotas. Revista de Ciências Humanas, Viçosa, v. 12, n. 2, p. 289-317, jul./dez. 2012.

SAMPIERI, Roberto Hernández. COLLADO, Carlos Fenández. LÚCIO, Pilar Baptista; tradução Fpatima Conceisão Murad, Melissa Kassner, Sheila Clara Dystyler Lareira. Metodologia de pesquisa. 3 ed. São Paulo: McGraw-Hill, 2006.

SIGNIFICADOS. Acesso. Disponível no sitio: http://michaelis.uol.com.br/moderno/portugues/index.php?lingua=portugues-

portugues\&palavra=acesso $>$. Acesso em 12 de Dezembro de 2014.

TREVISAN, Amarildo Luiz. DEVECHI, Catia Piccolo Viero. DIAS, Evandro Dotto. Avaliação da Avaliação da pós-graduação em educação do brasil: quanta verdade é suportável? Avaliação, Campinas; Sorocaba, SP, v. 18, n. 2, p. 373-392, jul. 2013

UFMG. Universidade Federal de Minas Gerais. Relatório de Gestão 2011. Disponível no sítio:

<file:///C:/Users/DEG_Admin/Downloads/RELAT\%C3\%93RIO_DE_GEST\%C3\%83O_UF

MG_2008.pdf>. Acesso em 12 de Dezembro de 2014.

UERJ. Universidade Estadual do Rio de Janeiro. Sistema de Cotas. Disponível no sítio: <http://www.uerj.br/institucional>. Acesso em 11 de Dezembro de 2014.

UFRJ. Universidade Federal do Rio de Janeiro. Edital PPG em Antropologia social 48/2014. Disponível no sítio: <http://www.ufrj.br/docs/editais/2014/edital-2014-03-10_0903.pdf > Acesso em 11 de Dezembro de 2014.

. Universidade Federal do Rio de Janeiro. Edital PPG em Antropologia social

49/2014. Disponível no sítio: <http://www.ufrj.br/docs/editais/2014/edital-2014-03-10_09-

06.pdf > Acesso em 11 de Dezembro de 2014.

UNB. Universidade de Brasília. Análise do sistema de cotas para negros da universidade de Brasília. Decanato de ensino de graduação. Brasília: UnB, 2013. 
Universidade de Brasília. Centro de Desenvolvimento Sustentável (CDS). Mestrado inovador para comunidades tradicionais, indígenas e quilombolas terá nova turma no Centro de Desenvolvimento Sustentável da Universidade de Brasília. Disponível no sítio: <http://www.cds.unb.br/cds/portal2/index.php/pt/noticia/481-mestradoinovador-para-comunidades-tradicionais-indigenas-e-quilombolas-tera-nova-turma-no-centrode-desenvolvimento-sustentavel-da-universidade-de-brasilia>. Acesso em 13 de Dezembro de 2014.

Universidade de Brasília. Decanato de Assuntos Comunitários (DAC). Disponível no sítio: < http://www.unb.br/administracao/decanatos/dac/index1.php>. Acesso em 10 de Agosto de 2015.

Universidade de Brasília. Decanato de Pesquisa e Pós-graduação (DPP). Disponível no sítio: < http://www.unb.br/administracao/decanatos/dpp/>. Acesso em $10 \mathrm{de}$ Agosto de 2015.

UNB. Universidade de Brasília. Edital PPG em Antropologia 3/2014. Disponível no sítio: < http://dan.unb.br/images/pdf/ppgas-

selecao/2014/Edital_PPG_Antropologia_Mestrado2015.pdf> Acesso em 11 de Dezembro de 2014.

sítio:

Universidade de Brasília. Edital PPG em Antropologia 4/2014. Disponível no http://www.unb.br/posgraduacao/stricto_sensu/editais/12015/edital_antropologia_d_12015.pd f> Acesso em 11 de Dezembro de 2014.

. Universidade de Brasília. Edital PPG em Direitos 3/2015. Disponível no sítio: < http://www.unb.br/posgraduacao/stricto_sensu/editais/12016/edital_direito_md_12016.pdf> Acesso em 11 de Dezembro de 2014.

Universidade de Brasília. Edital PPG em Direitos Humanos e Cidadania

1/2015. Disponível no sítio: <

http://www.unb.br/posgraduacao/stricto_sensu/editais/22015/edital_ppgdh_m_22015.pdf>

Acesso em 11 de Dezembro de 2014.

Universidade de Brasília. Edital PPG em Sociologia 1/2015. Disponível no sítio: <http://www.ics.unb.br/sol/ppg/processo_seletivo/2014/Edital-Mestrado-Doutorado.pdf>. Acesso em 11 de Dezembro de 2014.

Universidade de Brasília. Estatuto e Regimento Geral. Edição com emendas e alterações inseridas no Estatuto e no Regimento Geral, aprovadas pelo Conselho Universitário da UnB, por meio da Resolução n. 29/2010, de 7 de dezembro de 2010, publicada no DOU n. 21, de 31/1/2011, p. 124, Seção 1, e da Resolução n. 7/2011, de 24/5/2011, publicado no DOU n. 125 de 1\%/7/2011, p. 11, Seção 1.

Universidade de Brasília. Vestibular. Disponível no sítio: < http://www.unb.br/estude_na_unb/formas_de_admissao/vestibular.>. Acesso em 11 de Dezembro de 2014.

Universidade de Brasília. Lei 3.998/1961 que institui a FUB. Disponível no 
sítio: < http://www.unb.br/administracao/fub/lei.php.> Acesso em 25 nov 2015.

UNEB. Universidade do Estado da Bahia. Projeto mapeia trajetória de egressos do sistema de cotas para negros. Disponível no sítio: <http://www.uneb.br/2011/02/21/projeto-mapeiatrajetoria-de-estudantes-negros-egressos-do-sistema-de-cotas $>$. Acesso em 11 de Dezembro de 2014.

. Universidade do Estado da Bahia. Resolução 196/2012 Consu. Disponível no sítio: <http://www.ppgesa.uneb.br/arquivos/196\%20-\%20consu\%20-quotas\%20afro.pdf>. Acesso em 11 de Dezembro de 2014.

VELLOSO, Jacques. MELO, Lívia Veleda de Sousa e. Democratização do acesso à educação superior: o campus da UnB em Planaltina. Brasilia: Universidade de Brasília, 2011. 


\section{APÊNDICE 1}

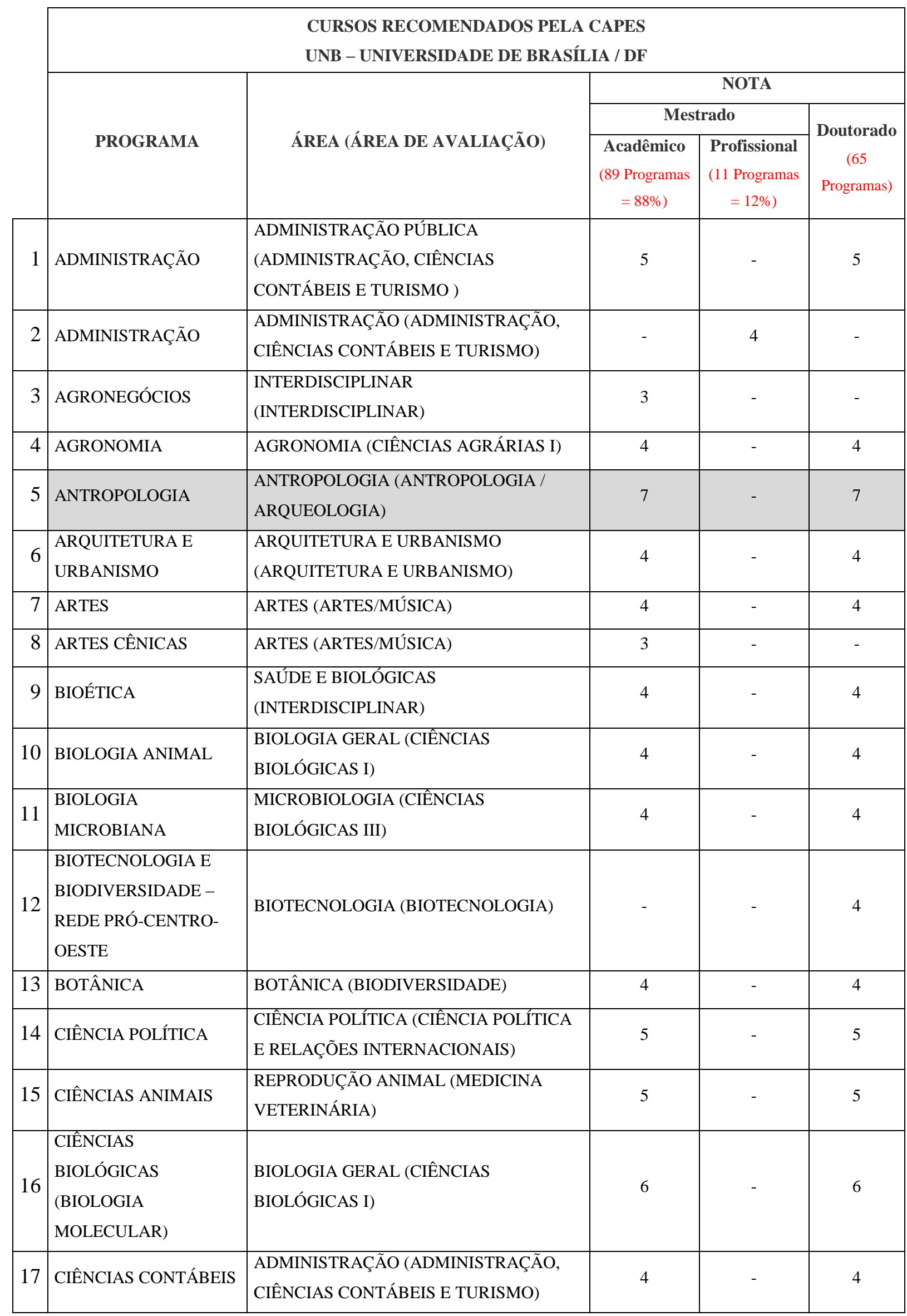




\begin{tabular}{|c|c|c|c|c|c|}
\hline 18 & $\begin{array}{l}\text { CIÊNCIAS DA } \\
\text { INFORMAÇÃO }\end{array}$ & $\begin{array}{l}\text { CIÊNCIA DA INFORMAÇÃO (CIÊNCIAS } \\
\text { SOCIAIS APLICADAS I) }\end{array}$ & 4 & - & 4 \\
\hline 19 & CIÊNCIAS DA SAÚDE & NEUROLOGIA (MEDICINA II) & 5 & - & 5 \\
\hline 20 & $\begin{array}{l}\text { CIÊNCIAS DE } \\
\text { MATERIAIS }\end{array}$ & MATERIAIS (MATERIAIS) & 3 & - & - \\
\hline 21 & $\begin{array}{l}\text { CIÊNCIAS DO } \\
\text { COMPORTAMENTO }\end{array}$ & PSICOLOGIA (PSICOLOGIA) & 4 & - & 4 \\
\hline 22 & $\begin{array}{l}\text { CIÊNCIAS E } \\
\text { TECNOLOGIAS EM } \\
\text { SAÚDE }\end{array}$ & $\begin{array}{l}\text { SAÚDE E BIOLÓGICAS } \\
\text { (INTERDISCIPLINAR) }\end{array}$ & 4 & - & 4 \\
\hline 23 & $\begin{array}{l}\text { CIÊNCIAS } \\
\text { FARMACÊUTICAS }\end{array}$ & FARMÁCIA (FARMÁCIA) & 4 & - & 4 \\
\hline 24 & $\begin{array}{l}\text { CIÊNCIAS } \\
\text { FLORESTAIS }\end{array}$ & $\begin{array}{l}\text { RECURSOS FLORESTAIS E } \\
\text { ENGENHARIA FLORESTAL (CIÊNCIAS } \\
\text { AGRÁRIAS I) }\end{array}$ & 4 & - & 4 \\
\hline 25 & $\begin{array}{l}\text { CIÊNCIAS } \\
\text { MECÂNICAS }\end{array}$ & $\begin{array}{l}\text { ENGENHARIA MECÂNICA } \\
\text { (ENGENHARIAS III ) }\end{array}$ & 4 & - & 4 \\
\hline 26 & CIENCIAS MÉDICAS & MEDICINA (MEDICINA I) & 4 & - & 4 \\
\hline 27 & $\begin{array}{l}\text { COMPUTAÇÃO } \\
\text { APLICADA }\end{array}$ & $\begin{array}{l}\text { CIÊNCIA DA COMPUTAÇÃO (CIÊNCIA } \\
\text { DA COMPUTAÇÃO) }\end{array}$ & - & 3 & - \\
\hline 28 & COMUNICAÇÃO & $\begin{array}{l}\text { COMUNICAÇÃO (CIÊNCIAS SOCIAIS } \\
\text { APLICADAS I) }\end{array}$ & 4 & - & 4 \\
\hline 29 & $\begin{array}{l}\text { CONTABILIDADE - } \\
\text { UNB - UFPB - UFRN }\end{array}$ & $\begin{array}{l}\text { CIÊNCIAS CONTÁBEIS } \\
\text { (ADMINISTRAÇÃO, CIÊNCIAS } \\
\text { CONTÁBEIS E TURISMO) }\end{array}$ & 5 & - & 5 \\
\hline 30 & $\begin{array}{l}\text { DESENVOLVIMENTO } \\
\text { SUSTENTÁVEL }\end{array}$ & $\begin{array}{l}\text { CIÊNCIAS AMBIENTAIS (CIÊNCIAS } \\
\text { AMBIENTAIS) }\end{array}$ & 6 & - & 6 \\
\hline 31 & $\begin{array}{l}\text { DESENVOLVIMENTO } \\
\text { SUSTENTÁVEL }\end{array}$ & $\begin{array}{l}\text { CIÊNCIAS AMBIENTAIS (CIÊNCIAS } \\
\text { AMBIENTAIS) }\end{array}$ & - & 3 & - \\
\hline 32 & $\begin{array}{l}\text { DESENVOLVIMENTO, } \\
\text { SOCIEDADE E } \\
\text { COOPERAÇÃO } \\
\text { INTERNACIONAL }\end{array}$ & $\begin{array}{l}\text { SOCIAIS E HUMANIDADES } \\
\text { (INTERDISCIPLINAR) }\end{array}$ & 4 & - & 4 \\
\hline 33 & DESIGN & $\begin{array}{l}\text { DESENHO INDUSTRIAL (ARQUITETURA } \\
\text { E URBANISMO) }\end{array}$ & 3 & - & - \\
\hline 34 & DIREITO & DIREITO PÚBLICO (DIREITO) & 6 & - & 6 \\
\hline 35 & $\begin{array}{l}\text { DIREITOS HUMANOS } \\
\text { E CIDADANIA }\end{array}$ & $\begin{array}{l}\text { INTERDISCIPLINAR } \\
\text { (INTERDISCIPLINAR) }\end{array}$ & 3 & - & - \\
\hline 36 & ECOLOGIA & ECOLOGIA (BIODIVERSIDADE) & 6 & - & 6 \\
\hline 37 & ECONOMIA & ECONOMIA (ECONOMIA) & 6 & - & 6 \\
\hline 38 & ECONOMIA & ECONOMIA (ECONOMIA) & - & 4 & - \\
\hline 39 & EDUCAÇÃO & EDUCAÇÃO (EDUCAÇÃO) & 4 & - & 4 \\
\hline
\end{tabular}




\begin{tabular}{|c|c|c|c|c|c|}
\hline 40 & EDUCAÇÃO & EDUCAÇÃO (EDUCAÇÃO) & - & 3 & - \\
\hline 41 & EDUCAÇÃO FÍSICA & EDUCAÇÃO FÍSICA (EDUCAÇÃO FÍSICA) & 4 & - & 4 \\
\hline 42 & ENFERMAGEM & ENFERMAGEM (ENFERMAGEM) & 3 & - & 3 \\
\hline 43 & $\begin{array}{l}\text { ENGENHARIA } \\
\text { BIOMÉDICA }\end{array}$ & $\begin{array}{l}\text { ENGENHARIA BIOMÉDICA } \\
\text { (ENGENHARIAS IV) }\end{array}$ & 3 & - & - \\
\hline 44 & $\begin{array}{l}\text { ENGENHARIA DE } \\
\text { SISTEMAS } \\
\text { ELETRÔNICOS E DE } \\
\text { AUTOMAÇÃO }\end{array}$ & $\begin{array}{l}\text { ENGENHARIA ELÉTRICA } \\
\text { (ENGENHARIAS IV) }\end{array}$ & 4 & - & 4 \\
\hline 45 & $\begin{array}{l}\text { ENGENHARIA } \\
\text { ELÉTRICA }\end{array}$ & $\begin{array}{l}\text { ENGENHARIA ELÉTRICA } \\
\text { (ENGENHARIAS IV) }\end{array}$ & - & 3 & - \\
\hline 46 & $\begin{array}{l}\text { ENGENHARIA } \\
\text { ELÉTRICA }\end{array}$ & $\begin{array}{l}\text { ENGENHARIA ELÉTRICA } \\
\text { (ENGENHARIAS IV) }\end{array}$ & 4 & - & 4 \\
\hline 47 & ENSINO DE CIÊNCIAS & $\begin{array}{l}\text { ENSINO DE CIÊNCIAS E MATEMÁTICA } \\
\text { (ENSINO) }\end{array}$ & - & 4 & - \\
\hline 48 & ENSINO NA SAÚDE & ENSINO (ENSINO) & 3 & - & - \\
\hline 49 & ESTATÍSTICA & $\begin{array}{l}\text { ESTATÍSTICA } \\
\text { (MATEMÁTICA/PROBABILIDADE E } \\
\text { ESTATÍSTICA) }\end{array}$ & 3 & - & - \\
\hline 50 & \begin{tabular}{|l|} 
ESTRUTURAS E \\
CONSTRUÇÃO CIVIL
\end{tabular} & ENGENHARIA CIVIL (ENGENHARIAS I) & 4 & - & 4 \\
\hline 51 & $\begin{array}{l}\text { ESTUDOS } \\
\text { COMPARADOS SOBRE } \\
\text { AS AMÉRICAS }\end{array}$ & $\begin{array}{l}\text { SOCIAIS E HUMANIDADES } \\
\text { (INTERDISCIPLINAR) }\end{array}$ & 4 & - & 4 \\
\hline 52 & $\begin{array}{l}\text { ESTUDOS DE } \\
\text { TRADUÇÃO }\end{array}$ & LETRAS (LETRAS/LINGUÍSTICA) & 3 & - & - \\
\hline 53 & FILOSOFIA & $\begin{array}{l}\text { FILOSOFIA (FILOSOFIA/TEOLOGIA: } \\
\text { subcomissão FILOSOFIA) }\end{array}$ & 4 & - & - \\
\hline 54 & FÍSICA & FÍSICA ( STRONOMIA/FÍSICA) & 4 & - & 4 \\
\hline 55 & FITOPATOLOGIA & AGRONOMIA (CIÊNCIAS AGRÁRIAS I) & 5 & - & 5 \\
\hline 56 & $\begin{array}{l}\text { GEOCIÊNCIAS } \\
\text { APLICADAS }\end{array}$ & GEOCIÊNCIAS (GEOCIÊNCIAS) & 4 & - & 4 \\
\hline 57 & GEOGRAFIA & GEOGRAFIA (GEOGRAFIA) & 4 & - & 4 \\
\hline 58 & GEOLOGIA & GEOLOGIA (GEOCIÊNCIAS) & 6 & - & 6 \\
\hline 59 & GEOTECNIA & GEOTÉCNICA (ENGENHARIAS I) & 6 & - & 6 \\
\hline 60 & GESTÃO PÚBLICA & $\begin{array}{l}\text { ADMINISTRAÇÃO PÚBLICA } \\
\text { (ADMINISTRAÇÃO, CIÊNCIAS } \\
\text { CONTÁBEIS E TURISMO) }\end{array}$ & - & 3 & - \\
\hline 61 & HISTÓRIA & HISTÓRIA (HISTÓRIA) & 4 & - & 4 \\
\hline 62 & INFORMÁTICA & $\begin{array}{l}\text { CIÊNCIA DA COMPUTAÇÃO (CIÊNCIA } \\
\text { DA COMPUTAÇÃO) }\end{array}$ & 4 & - & 4 \\
\hline
\end{tabular}




\begin{tabular}{|c|c|c|c|c|c|}
\hline 63 & $\begin{array}{l}\text { INTEGRIDADE DE } \\
\text { MATERIAIS DA } \\
\text { ENGENHARIA }\end{array}$ & $\begin{array}{l}\text { ENGENHARIA MECÂNICA } \\
\text { (ENGENHARIAS III) }\end{array}$ & 3 & - & - \\
\hline 64 & LINGUÍSTICA & LINGUÍSTICA (LETRAS/LINGUÍSTICA) & 4 & - & 4 \\
\hline 65 & $\begin{array}{l}\text { LINGUÍSTICA } \\
\text { APLICADA }\end{array}$ & $\begin{array}{l}\text { LINGUÍSTICA APLICADA } \\
\text { (LETRAS/LINGUÍSTICA) }\end{array}$ & 3 & - & - \\
\hline 66 & LITERATURA & LETRAS (LETRAS/LINGUÍSTICA) & 5 & - & 5 \\
\hline 67 & MATEMÁTICA & $\begin{array}{l}\text { MATEMÁTICA } \\
\text { (MATEMÁTICA/PROBABILIDADE E } \\
\text { ESTATÍSTICA) }\end{array}$ & 7 & - & 7 \\
\hline 68 & MEDICINA TROPICAL & $\begin{array}{l}\text { DOENÇAS INFECCIOSAS E } \\
\text { PARASITÁRIAS (MEDICINA II) }\end{array}$ & 4 & - & 4 \\
\hline 69 & $\begin{array}{l}\text { MEIO AMBIENTE E } \\
\text { DESENVOLVIMENTO } \\
\text { RURAL }\end{array}$ & $\begin{array}{l}\text { MEIO AMBIENTE E AGRÁRIAS } \\
\text { (INTERDISCIPLINAR) }\end{array}$ & 3 & - & - \\
\hline 70 & MÚSICA & MÚSICA (ARTES/MÚSICA) & 3 & - & - \\
\hline 71 & \begin{tabular}{|l|} 
NANOCIÊNCIA E \\
NANOBIOTECNOLOGIA
\end{tabular} & $\begin{array}{l}\text { ENGENHARIA/TECNOLOGIA/GESTÃO } \\
\text { (INTERDISCIPLINAR) }\end{array}$ & 4 & - & 4 \\
\hline 72 & NUTRIÇÃO HUMANA & NUTRIÇÃO (NUTRIÇÃO) & 4 & - & 4 \\
\hline 73 & $\begin{array}{l}\text { PATOLOGIA } \\
\text { MOLECULAR }\end{array}$ & $\begin{array}{l}\text { IMUNOLOGIA (CIÊNCIAS BIOLÓGICAS } \\
\text { III) }\end{array}$ & 5 & - & 5 \\
\hline 74 & POLÍTICA SOCIAL & SERVIÇO SOCIAL (SERVIÇO SOCIAL) & 6 & - & 6 \\
\hline 75 & $\begin{array}{l}\text { PROCESSOS DE } \\
\text { DESENVOLVIMENTO } \\
\text { HUMANO E SAÚDE }\end{array}$ & $\begin{array}{l}\text { PSICOLOGIA DO DESENVOLVIMENTO } \\
\text { HUMANO (PSICOLOGIA) }\end{array}$ & 4 & - & 4 \\
\hline 76 & $\begin{array}{l}\text { PSICOLOGIA CLÍNICA } \\
\text { E CULTURA }\end{array}$ & PSICOLOGIA (PSICOLOGIA) & 5 & - & 5 \\
\hline 77 & $\begin{array}{l}\text { PSICOLOGIA SOCIAL, } \\
\text { DO TRABALHO E DAS } \\
\text { ORGANIZAÇÕES } \\
\text { (PSTO) }\end{array}$ & PSICOLOGIA (PSICOLOGIA) & 5 & - & 5 \\
\hline 78 & QUÍMICA & QUÍMICA (QUÍMICA) & 5 & - & 5 \\
\hline 79 & $\begin{array}{l}\text { REGULAÇÃO E } \\
\text { GESTÃO DE } \\
\text { NEGÓCIOS }\end{array}$ & $\begin{array}{l}\text { ENGENHARIA/TECNOLOGIA/GESTÃO } \\
\text { (INTERDISCIPLINAR) }\end{array}$ & - & 3 & - \\
\hline 80 & $\begin{array}{l}\text { RELAÇÕES } \\
\text { INTERNACIONAIS }\end{array}$ & $\begin{array}{l}\text { POLÍTICA INTERNACIONAL (CIÊNCIA } \\
\text { POLÍTICA E RELAÇÕES } \\
\text { INTERNACIONAIS) }\end{array}$ & 6 & - & 6 \\
\hline 81 & SAÚDE ANIMAL & $\begin{array}{l}\text { MEDICINA VETERINÁRIA (MEDICINA } \\
\text { VETERINÁRIA) }\end{array}$ & 4 & - & 4 \\
\hline 82 & SAÚDE COLETIVA & SAÚDE COLETIVA (SAÚDE COLETIVA) & 4 & - & 4 \\
\hline 83 & SAÚDE COLETIVA & SAÚDE COLETIVA (SAÚDE COLETIVA) & - & 3 & - \\
\hline
\end{tabular}




\begin{tabular}{|c|c|c|c|c|c|}
\hline 84 & $\begin{array}{l}\text { SISTEMAS } \\
\text { MECATRÔNICOS }\end{array}$ & $\begin{array}{l}\text { ENGENHARIA MECÂNICA } \\
\text { (ENGENHARIAS III) }\end{array}$ & 4 & - & 4 \\
\hline 85 & SOCIOLOGIA & SOCIOLOGIA (SOCIOLOGIA) & 6 & - & 6 \\
\hline 86 & $\begin{array}{l}\text { TECNOLOGIA } \\
\text { AMBIENTAL E } \\
\text { RECURSOS HÍDRICOS }\end{array}$ & $\begin{array}{l}\text { ENGENHARIA SANITÁRIA } \\
\text { (ENGENHARIAS I) }\end{array}$ & 4 & - & 4 \\
\hline 87 & $\begin{array}{l}\text { TECNOLOGIAS } \\
\text { QUÍMICA E } \\
\text { BIOLÓGICA }\end{array}$ & $\begin{array}{l}\text { ENGENHARIA/TECNOLOGIA/GESTÃO } \\
\text { (INTERDISCIPLINAR) }\end{array}$ & 4 & - & 4 \\
\hline 88 & TRANSPORTES & $\begin{array}{l}\text { ENGENHARIA DE TRANSPORTES } \\
\text { (ENGENHARIAS I) }\end{array}$ & 4 & - & 4 \\
\hline 89 & TURISMO & $\begin{array}{l}\text { TURISMO (ADMINISTRAÇÃO, CIÊNCIAS } \\
\text { CONTÁBEIS E TURISMO) }\end{array}$ & - & 3 & - \\
\hline 90 & ZOOLOGIA & ECOLOGIA (BIODIVERSIDADE) & 4 & - & 4 \\
\hline
\end{tabular}

Fonte: Sistema Nacional de Pós-graduação (SNPG)/CAPES

Disponível no sitio:

<http://conteudoweb.capes.gov.br/conteudoweb/ProjetoRelacaoCursosServlet?acao=pesquisarRegiaoIesProgram a\&codigoIes=53001010\&conceito=\#>, Acesso em 25 de Novembro de 2014. Data de atualização: 20/03/2015.

Legenda:

M - Mestrado Acadêmico

D - Doutorado

F - Mestrado Profissional

M/D - Mestrado Acadêmico/Doutorado 


\section{APÊNDICE 2}

\section{Entrevistado (E1):}

\section{Diretor em exercício (2012-2016) da Diretoria de Pós-graduação (DIRPG), ligada à Administração Superior - Decanato de Pesquisa e Pós-graduação (DPP) da Universidade de Brasília.}

Entrevistador: Não sei se a Socorro passou alguma coisa sobre o, pelo menos o tema da dissertação.

Entrevistado (E1): Superficialmente. Só sobre ações afirmativas na pós-graduação que esse era o tema.

Entrevistador: Eu estou estudando ações afirmativas que ampliam acesso da população negra nos cursos de pós-graduação stricto sensu. E aí, isso o que que motivou? Existe pouca coisa com relação a isso e tem uma, no plano nacional de educação, tem uma meta, uma estratégia do MEC que inclui lá, então é como se fosse uma oportunidade para as instituições repensarem isso, já que a gente tem dez anos de implantação efetiva de ações em graduação e pouco se fala da pós-graduação, então, a gente resolveu falar sobre esse tema. Eu sou aluna da pós-graduação do programa de pós-graduação lá da FUP, de gestão pública, coordenado pela professora Andréa que, inclusive, é minha orientadora.

Entrevistado (E1): Conheço ela.

Entrevistador: Conhece? E aí eu vi aqui que você tem uma experiência em gestão. Então, essa gestão, a política, inclusive, em coordenação de curso de pós-graduação. Então, você está por dentro do teor do assunto. E eu estava vendo, também, que essa diretoria ela acompanha administrativa e faz acompanhamento dos programas de pós-graduação da UnB. Evolve latu sensu e stricto sensu, isso tudo e faz estudos, emite parecer que são relacionados à área.

Entrevistado (E1): Você quer um resumo do que que a diretoria faz?

Entrevistador: Gostaria para eu entender melhor. 
Entrevistado (E1): O programa de pós-graduação na Universidade de Brasília, ele é organizado pelo decanato de pesquisa e pós-graduação. Está abaixo de uma câmara de conselheiros chamada Câmara de Pesquisa e Pós-Graduação, são representantes de cada unidade que tem pós-graduação, então, ele tem um representante que é o nosso suplente que vem aqui na Reitoria a cada duas semanas, tem uma reunião dessa câmara, para resolver os problemas burocráticos da pós-graduação. O problema é rente aluno e professor, professor e aluno, projeto de pesquisa, criação de curso, regulamento, resolução. Tudo isso é discutido na câmara, então, as decisões do decanato, não são decisões de um diretor ou de um decano, é a decisão do colegiado, é feito em conjunto com esses representantes da Câmara. Cada programa tem que ter um colegiado. Então, cada programa foi criado, na verdade, por iniciativa de um grupo de professores, então, um grupo de professores se reúne e quer fazer um curso, por exemplo, de gestão como foi feito no caso do curso de que você faz parte agora, era a professora da administração, juntou outros professores e fizeram uma proposta. Essa proposta tem que estar no modelo do Ministério da Educação pela CAPES, então, existe, a CAPES tem, também, um grupo de consultores que avaliam as propostas de cursos de pósgraduação e tem as regras nos modelos de como é que tem que ser um curso de pósgraduação. Então, as pessoas pegam esse modelo de várias Universidades do país juntam os professores e fazem a proposta. Aí, nessa proposta, eu tenho que ter um grupo de número $\mathrm{X}$ de professores, os professores tem que estar atuando, tem que ter publicação, podem ou não já ter orientado na pós-graduação, melhor ter orientado, que sejam pessoas mais experientes. Então, essa proposta de curso passa pela câmara, se aprovada, vai para a CAPES, aí a CAPES avalia de novo com um grupo de consultores, se aprovado na CAPES, o reitor autoriza o funcionamento do curso e o curso começa a funcionar. Esse curso tem um colegiado que é escolhido, está tudo no regulamento, o regulamento que é feito entre escola e colegiado e tem uma comissão. A Comissão Executiva que faz com que o programa ande. Então, qualquer decisão que acontece, quem faz é a comissão, o coordenador ele simplesmente preside a comissão e o colegiado. Então, todos os problemas são encaminhados para cá via o coordenador. Mas quem decide é aquela comissão e o colegiado do programa e aqui quem decide é a Câmara de Pesquisa e Pós-Graduação. Em relação à inclusão de alunos, por exemplo, cada programa pode fazer o seu edital de seleção, existe um modelo que nós fizemos de como se faz um edital de seleção de alunos. Esse modelo está no portal do decanato. Então, esse edital é geral, quais são as etapas que tem que ter esse edital, como ele tem que ser feito, quanto tempo para cada, distância para cada etapa e tudo mais, os recursos. 
Então, é bem uniforme o edital, só que tem a peculiaridade de cada programa, cada programa pode mudar um pouquinho aqui e ali dependendo da especificidade de cada programa. E nesse edital, a primeira vez que surgiu uma solicitação de cotas para negros ou para indígenas foi ano passado, antes disso, nunca havia nenhum questionamento, nenhum pedido nem nada. Então, são noventa e dois programas na Universidade de Brasília, envolvem oito mil alunos matriculados, cada programa a demanda por vaga é diferente. Eu fui coordenador de dois programas, um Biologia Molecular que é avaliado como seis na CAPES e um Patologia Molecular que é avaliado como cinco. Biologia Molecular é da Biologia e Patologia Molecular da Faculdade de Medicina. Nesses programas a demanda, geralmente, é dois alunos por vaga mais ou menos, de dois a três no máximo e a grande maioria das pessoas que... Então, voltando, são noventa e dois programas de pós-graduação, esses noventa e dois programas nas diversas áreas de conhecimento, muitos programas foram criado na década, alguns na verdade, não muitos, final da década de sessenta, outros no início da década de setenta e muitos mais recentemente. A grande maioria dos cursos foram criados mais recentemente e, hoje em dia, a Universidade de Brasília é a terceira Universidade do país com mais número de curso de pós-graduação stricto sensu. Em primeiro lugar é a USP, em segundo lugar a UFRJ, em terceiro lugar é a Universidade de Brasília. Então, como eu estava falando, os cursos de pós-graduação são bem heterogêneos e a concorrência é muito menor do que no vestibular para graduação, especificamente se você olha para um curso bem específico como, por exemplo, Biotecnologia ou Nanobiotecnologia ou Engenharia Biomédica, não é um curso que é procurado por muita gente. Agora, se você olhar para educação, direito, administração, como existem várias faculdades de graduação e são cursos tradicionais, a procura para a pós-graduação nesses cursos é muito grande, então, a competição é muito maior, então, nos cursos que são mais específicos não existe o problema entrada de gente e de vaga, não existe esse problema, porque entra se você é capaz, não tem competição que é um para um, dois para um, então, não precisa de ação afirmativa. Sinceramente não precisa. Só você saber o mínimo você entra em um curso desses. Agora, programas que são altamente competitivos, aí sim vai entrar quem realmente está melhor preparado, teve uma melhor graduação e tudo mais, então, nesses casos, pode ocorrer a necessidade de alguma reserva de vaga. No caso de indígenas já é bem diferente, esses indígenas não tiveram uma base muito boa, porque você mesmo fazendo graduação, tem muito indígena ainda que não tem uma base boa e, talvez, não saiba fazer um processo, encarar um processo de ser aprovado. Então, até o momento, a grande maioria dos programas não se preocupou com isso. Só em 2004, quando a Sociologia veio conversar comigo, o coordenador da Sociologia e da Antropologia, também, 
perguntando sobre como é que, se a câmera aceitaria a reserva de vagas para negro e para indígena no edital. Eu falei: Eu tenho que passar para a câmara, então, você sugere na reunião e a gente discute na reunião, então, foi sugerido, no final do ano passado de 2014, e o que ficou decidido, que cada programa decide. Então, se o programa quiser achar que é importante ter reserva de vaga no edital ele está liberado para fazer, a Universidade permite, o decanato ou a câmara permitiu abertura de concurso com reserva de vaga, aí quem decide isso é o programa, tem toda autonomia para saber quantas vagas vão ser reservadas e se vão ser reservadas ou não. Então, hoje, o que que já aconteceu? Dois editais da Sociologia 2004, 2015, geralmente, entre dez e vinte por cento de vagas, a Antropologia, também, e o Direito começou esse semestre e o Direitos Humanos e Cidadania outro curso que começou, também, esse semestre. Então, são quatro cursos na Universidade de Brasília que tem reserva de vaga para indígena e negro atualmente. Essa é a situação atual de como é a reserva de vagas, então, a opinião minha não interessa, é a opinião da câmara, isso se decide na câmara, então, cada um pode ter sua opinião e ela é discutida e decidida no colegiado e o colegiado decidiu dessa forma. $\mathrm{O}$ representante de estudantes, hoje mesmo na reunião que teve, ele sugeriu que fosse feito uma comissão para avaliar a obrigatoriedade de cotas na pós-graduação. O decano, como presidente da CPP, simplesmente disse que é esse tipo de discussão pode ser levantador no fórum de pós-graduação que vai ocorrer aqui agora em Outubro, no dia quatorze de Outubro, onde vai ser discutido o regulamento atual da pós-graduação, que é uma resolução de 2004, resolução 91/2004, é o regulamento que rege toda a pós-graduação, então, sugiro que você leia de cima a baixo esse regulamento, você sabe como é que funciona. Então, vai ser revisto esse regulamento e na hora de rever esse regulamento, talvez, esse tópico pode ser discutido, mas como eu falei, a minha opinião não interessa, mas a minha opinião é que não é necessário para todo mundo.

Entrevistador: Mas assim, é que eu estou pesquisando, querendo ver não a opinião, mas institucionalmente às ações que estão sendo feitas, quem é responde institucionalmente é o DPP, não é? Se falar em UnB, quem é responsável...

Entrevistado (E1): Sim, a pós-graduação é o DPP.

Entrevistador: Aí, pelas coisas que estou pesquisando, assim, então, entre 2004 e 2014 não foi desenhada nenhuma política institucional, como você me respondeu, tem políticas por programa, os programas desenharam as suas políticas particulares, até porque, vocês não 
percebem a necessidade de rever a política porque é muito peculiar de cada curso. Então, esse decanato, foi feito algum estudo já pelo decanato?

Entrevistado (E1): Não.

Entrevistador: Mas, nem por essa comissão...

Entrevistado (E1): Não. Não tem nenhuma comissão que estudou cotas na pós-graduação. Foi sugerido em uma reunião a montagem de uma comissão, não tem ainda essa comissão, pode ser montada agora nesse fórum da pós-graduação que vai ser feito em outubro.

Entrevistador: E você conhece outras experiências de fora, institucionais? Por exemplo, a experiência da Bahia, porque a Bahia ela implantou assim, foi institucional, o DPP de lá implantou reserva...

Entrevistado (E1): Nem precisava, não é? Setenta por cento de negro na Bahia e tem que ter cota? Que coisa. E só olhar para lá mesmo, tem preto na Bahia então tem que colocar na Universidade.

Entrevistador: E eles implantaram, foi realmente institucional. Todos os cursos de todos os programas, todos editais de graduação e pós-graduação, de todas as unidades acadêmicas de lá tem a reserva. É a única que fez isso, mas tem essa razão que o senhor falou.

Entrevistado (E1): É. Uma grande maioria negra e só tinha branco na Universidade, aí também é complicado.

Entrevistador: Então, vocês avaliam dificuldades institucionais para desenhar e implantar alguma ação?

Entrevistado (E1): Não existem dificuldades basta à questão de conversar, porque nós funcionamos em órgãos colegiados, então, não é uma decisão de uma pessoa, não é uma decisão do decano ou do reitor, nem nada, se a CPP achar que tem que implantar ela sugere. Aí vai para o CEPE que é o Conselho de Pesquisa e Extensão e eles aprovam ou não, mas a proposição disso está aberta, não existe proibição nem nada, é algo que pode ser discutido. Eu 
acho que vai chegar o momento, agora o que que aconteceu, o número de estudantes de pósgraduação aumentou muito ao longo dessa última década, era realmente pequeno, então, essa população que está crescendo, o número de pós graduandos, com certeza, está gerando uma demanda para a pós-graduação, está aumentando isso e isso pode resultar e todos precisarem, mas também, se o reitor quiser começar essa discussão ou alguém mais, o próprio decano, se ele quisesse, vamos discutir, eu, como decano, eu vou implantar uma comissão, ele poderia, mas esse decano eu acho que não pensa desse jeito, no momento.

Entrevistador: Assim, institucionalmente tem que ser feita ação, você acha que tem que ser feita ação do DPP junto com outros setores da Universidade para funcionar esse suporte para a população negra?

Entrevistado (E1): O DPP ele pode, como fez, permitir que os programas abram ação afirmativa, agora para manter, por exemplo, se você assumir que a população negra é a população mais carente e precisa de assistência na pós-graduação, tem que envolver o DAC, Diretoria de Assuntos Comunitários. Então, teria que ter o envolvimento de outro decanato. Porque na pós-graduação nós temos em torno de oito mil alunos e apenas duas mil bolsas de pós-graduação. Então ficam seis mil alunos sem bolsa. A grande maioria trabalha e não precisa de bolsa e tal, teve um aumento significativo no número de bolsas. Mas tem muita gente que não vai fazer pós-graduação, porque não tem dinheiro, é pobre e não consegue, então, com certeza, se começar a aumentar o número de vagas na pós-graduação, vai ter que, necessariamente, as pessoas para ficar na pós-graduação vão ter que ter ajuda financeira. $O$ governo dá para a graduação, está tentando manter ajuda financeira, o auxílio ao estudante. Aí na pós-graduação não tem isso. Outro problema, as áreas são bem diferentes, por exemplo, eu sou biólogo trabalho com vírus de inseto e tenho um laboratório, então, tem um limite, de cinco a oito alunos, hoje tem doze, mas cinco a dez alunos de graduação eu posso orientar e o aluno, por exemplo, como é que eu oriento o aluno? Eu tenho um projeto de pesquisa que eu escrevi para ganhar dinheiro, para fazer aquele projeto de pesquisa. Eu quero saber a diversidade de vírus de inseto na população de borboletas e mariposas aqui do cerrado. Então, eu tenho que sair coletando as mariposas, identificando vírus, fazendo sequenciamento de genoma e tudo mais, eu preciso de gente experiente para fazer isso, que o projeto de pesquisa dura dois anos, então eu vou pegar um mestrado que seja capaz de fazer as metodologias que eu quero, eu não vou pegar alguém que, simplesmente, saiu de um curso de graduação sem saber nada, impossível, é um tipo de trabalho muito técnico que precisa de habilidade técnica. 
Então não é só, não é um curso que você senta, lê e faz prova, é um curso que você tem que ter habilidade de pesquisa mesmo, então, é muito mais difícil você achar gente, por isso que no curso de pós-graduação dessas áreas experimentais é muito menos concorrido, porque as pessoas tem que ter uma certa habilidade, não é só estudar, então, é meio delicado. Às vezes todo mundo quer, vamos fazer geral, mas tem que analisar a especificidade de cada programa, porque não dá pra você gerar para todo mundo, mesmo porque não teria até concorrente às vezes, você não teria gente para assumir aquela vaga. Você pode até ter, seria uma política, vamos abrir vaga e tudo mais, se não tiver candidato, não entra. Se tiver candidato e se tiver a vaga vai entrar, só que nós estamos em um momento em que você não pode, ou, não diria não pode reprovar, mas a CAPES exige que você termine a tese ou a dissertação. É uma pressão danada, porque senão o programa perde nota. Você sabe como é que são as notas da CAPES? As notas são feitas da seguinte forma: Você tem, todo ano o coordenador do programa, ele pega as informações com o orientador, quantos trabalhos você publicou esse ano, quantos alunos você orientou, quantas disciplinas você deu na graduação e na pós-graduação, você tem aluno de iniciação científica, me fala tudo que você fez. Você pega algumas informações curriculares e você gera um relatório online que é isso aqui, a plataforma Sucupira, então todo programa você pode saber quais são os professores, alunos, trabalhos publicados de todo mundo e de todos os programas pós-graduação no país que é isso aqui.

Entrevistador: Ele é público?

Entrevistado (E1): Público. Então, está aqui, plataforma Sucupira, dados cadastrais do programa, programa da disciplina, financiadores, proposta, discentes, docentes, projeto de pesquisa, disciplinas, turmas, condições intelectuais, por exemplo, eu clico aqui condições intelectuais, aí ele me pergunta qual a Universidade, qual o ano, 2014, porque o relatório 2015 não tá aberto para preenchimento, 2014 já foi...

Entrevistador: É do primeiro semestre, não é?

Entrevistado (E1): É. Já foi fechado. 2015, na verdade, você começa em 2016, porque você tem que esperar até dezembro, já faz no outro ano. Então, é só clicar, eu coloco aqui UnB, aí ele vai procurar, aí você seleciona o seu programa, gestão, gestão pública, aí você pode procurar por título, autor ou tipo de produção, se é artigo bibliográfico, subtítulo, certinho, jornal, periódico, e tal, então, periódico, ele me dá uma lista, sua orientadora, o que que foi 
publicado, o nome do título do artigo que foi publicado e tal e os detalhes. No total foram trinta registros de artigos publicados em 2014, então, o coordenador faz isso com todos os orientadores, publicação de orientador, isso em todo o Brasil, para você ter uma ideia, a CAPES divide as áreas em quarenta e sete áreas diferentes, e cada área pode ter até centenas de cursos, por exemplo, a Biologia Molecular, que é o curso que eu fui coordenador, é da área de Ciências Biológicas 1, se eu não me engano tem cento e vinte cursos, então, cada coordenador desses cursos faz um relatório e envia para a CAPES, aí essa área, Ciências Biológicas 1, tem um comitê que vai avaliar todos os relatórios comparativamente com todos os outros, e vê qual o melhor relatório, quem tem as melhores revistas que são publicadas com uma maior quantidade de artigos, defesa, se defendeu no tempo, se não defendeu no tempo e tudo mais, e você dá uma nota, um número, é uma avaliação daquele programa, olhando todos os outros, o melhor programa foi você, então, esse programa é o melhor que tem, então, ele vai ter a nota maior, só que a qualidade dele, ele publica, aí que vem, ele é bom, então no mínimo ele é cinco, ele é o melhor de todos, esse é minha nota cinco, aí você olha, ele tem projetos internacionais, colaboração internacional, publica em outra língua e tudo mais, aí se ele tem isso, internacionalização, ele é considerado de excelência, seis ou sete, sete é o máximo, seis é a excelência, também, internacional, aí eles ganham dinheiro separadamente, quem é seis e sete a CAPES dá dinheiro diretamente para o coordenador, quem é cinco para baixo o dinheiro vem para cá, para o DPP, para a gente ajudar os programas, então, é meritocracia, eles olham para os melhores parâmetros de cada programa. Então, para você chegar a esses melhores parâmetros, você tem que escolher os melhores alunos, os alunos tem que produzir todo ano, então, é uma pressão danada para você se manter no topo, você pode se manter como três e quatro, mas você não ganha muito dinheiro, o seu curso não tem muito prestígio, para você ter uma ideia, a UFMG tem setenta e sete cursos de pós-graduação, dois terços dos cursos da UFMG tem nota entre cinco, seis e sete, já a UnB tem noventa e dois, dois terços três e quatro, então, tem muito curso, mas a qualidade ainda não está lá em cima, então, precisa melhorar. Então, a qualidade é dos professores, dos alunos, do que é feito na pós-graduação, então, a gente tenta melhorar esses parâmetros na pós-graduação, então, é muito puxado mesmo, porque não pode ter a vazão, tem que publicar, então, tem várias resoluções dizendo que se você entrou no mestrado, você tem que sair publicando alguma coisa, não pode sair apenas passando em prova e acabou, você tem que ter um resultado, uma produção científica do seu mestrado e do seu doutorado. Então, muitos os que são de excelência, seis e sete aqui, exigem, no mínimo, um artigo publicado em revista internacional, os melhores, outros exigem apenas um artigo publicado em revista indexada e, dependendo da 
área, as exigências são diferentes, então, é uma pressão danada. Então, as pessoas estão mais preocupadas em atrair alunos bons do que atrair muitos alunos. Então, não é quantidade, tem que ser diferente, não é olhar para a pós-graduação, como a graduação que é quantidade, a pós-graduação não foi feita para todo mundo, ela foi feita para quem quer se especializar na área porque, às vezes, a gente está tentando ter um olhar para a pós-graduação como continuidade da graduação, e não deve ser assim, a pós-graduação é para realmente quem está envolvido na academia que quer se especializar e que quer para um nicho específico, porque você vai ficar muito tempo sem ganhar dinheiro, acabou a graduação você entra na pósgraduação para se especializar, e que o grande problema, também, é que o governo agora dá incentivo para quem está no governo, se você tem uma pós-graduação o seu salário aumenta, então, muita gente quer entrar na Universidade para aumentar o salário, não para fazer um curso de pós-graduação como ele deve ser feito, então, a qualidade do aluno não é aquela coisa, para você ter ideia, eu já orientei vinte e nove mestres e quinze doutores de noventa e três para cá, são vinte e dois anos. Desses, eu conto em uma mão os que são realmente que nasceram para fazer doutorado, e a partir dali, seguir uma carreira acadêmica. Não quer dizer que o cara que faz doutorado só vai para a academia, ele pode ir para a indústria, fazer outra coisa, mas o cara que faz doutorado não pode fazer concurso público para ser um burocrata, dependendo da área. Se ele faz um doutorado em gestão, tudo bem, é aquilo que você tem que ser, você faz o doutorado em vírus de inseto, especificamente em uma área específica eu acho um desperdício e é incentivado por, sei lá, por querer ter doutorado, mas, também, pelo estímulo do serviço público que dá um aumento no salário só porque ele tem doutorado e ele não se dedica no doutorado, porque ele poderia se dedicar muito bem ao doutorado, e nem no trabalho se ele está trabalhando. Por isso que a exigência na pós-graduação é de você receber bolsa, mas ter dedicação exclusiva, porque não é fácil, pós-graduação não deve ser fácil. Não é para te dar apenas outro título, é para realmente quem quer fazer aquilo. Então, a discussão eu acho que está muito mais, tem gente que não entende bem o processo de pós-graduação e quer simplesmente aumentar vaga, aumentar, aumentar e ....

Entrevistador: Mas, assim, pegando esse gancho que falou que não é uma extensão da graduação, mas contextualizando para as ações afirmativas, porque tem aí dez anos que está implementado o número de negros na graduação, essa mesma proporção não poderia, proporcionalmente, a pós-graduação olhar isso, porque também tem essa meta do governo que o DPP tem que responder. 
Entrevistado (E1): Teoricamente. Se o governo baixar uma lei, tudo bem, mas, teoricamente a Universidade tem autonomia universitária, escolhe quem pode entrar aqui ou não, não é o governo que vai dizer, porque a Universidade, teoricamente, tem essa autonomia, só que, na verdade, não tem. Todo o dinheiro vem do governo, mas, teoricamente, eu posso, o conselho pode dizer: Não, nós temos autonomia didática de ensino, para quem entrar aqui ele ter esse perfil.

Entrevistador: Então, vocês não pensam em pegar esse público e avaliar, desse público, quem tem esse perfil de pesquisador, esse olhar, sabe? Conciliando as duas coisas.

Entrevistado (E1): Perfeito. Só que como eu te falei, muitos programas não precisam fazer isso, porque tem vaga, não é competitivo, quem está se formando não tem problema, pelo menos em alguns, depende da pessoa, quem é racista ele vai ser racista se ele é branco, preto ou azul ou o caramba, mas se essa pessoa na academia ele está preocupado com outra coisa, com o trabalho dele, se a pessoa é boa ou não para trabalhar, então, eu acredito ainda que a seleção feita em um curso sério é feita pelo mérito, independente da cor da pessoa, como eu te falei, mesmo porque, você tem vaga sobrando, se a pessoa é boa pessoa, a pessoa vai querer que a pessoa trabalhe lá. Agora, você tem outros cursos que estão bem demandados, tem muita gente, aí, nesse caso, há uma necessidade de você ter ação afirmativa, porque a maioria das pessoas que vão concorrer não são negras, não são indígenas.

Entrevistador: Então, nesse sentido, não tem nenhuma, assim, uma ação do DPP para ter esse olhar?

Entrevistado (E1): Não. Ainda não.

Entrevistador: E como é que vocês veem essa iniciativa da Antropologia, da Sociologia, do Direito...

Entrevistado (E1): Direitos Humanos e Cidadania. Então, é uma iniciativa dos cursos da área de humanas aonde existe uma maior discussão sobre esses assuntos, porque a natureza dos cursos de humanas, de ter o debate, de discutir e tudo mais, já os outros cursos mais tecnológicos e biológicos são mais práticos, sem discutir muito, mais técnicos. Eu estou pensando na técnica, não no geral, na sociedade, então, eu acho normal, compreensível e a 
gente apoia, mesmo porque, foi aprovado pela CPP que eles podem fazer o que eles e quiserem, sem problema nenhum.

Entrevistador: Mas vocês acompanham resultado...

Entrevistado (E1): Como eu te falei. Só tem dois semestres que ocorreu esse tipo de ação.

Entrevistador: Não tem turma formada.

Entrevistado (E1): Não tem. Só entrou um no primeiro semestre de 2015. A seleção foi no segundo de 2014 para começar em 2015. Então, começou agora. E tem essa seleção agora para entrar no primeiro de 2016. Então, a nossa primeira turma entrou efetivamente nesse ano, então está todo mundo fazendo ainda. Aliás são duas, por exemplo, a Antropologia duas vagas de mestrado, três de doutorado, Sociologia, mais ou menos isso, dois e três.

Entrevistador: E você já teve feedback se entrou negro nessas vagas?

Entrevistado (E1): Não. Tem as vagas aí, não sei se entraram ou não. Eu acho que deve ter entrado em Direito e Direitos Humanos, porque a concorrência é muito grande. Em Antropologia eu não sei, porque eu não sei qual é a proporção muito grande. Mas o interessante é você conversar com esses quatro cursos, quatro cursos só. Se você quiser o contato eu passo para você dos coordenadores.

Entrevistador: Vou querer sim. Acho que é isso, porque, na verdade..

Entrevistado (E1): É porque você fez uma questão como já tivesse tudo andando, já tivesse sido avaliado.

Entrevistador: Um estudo, já tivesse tido uma ação. Mas, não, se eu for seguir aqui entre 2004 e 2014 se desenhou alguma política pública de forma institucional? Não.

Entrevistado (E1): Não.

Entrevistador: Por que? 
Entrevistado (E1): Porque essa demanda não surgiu, não tinha surgido ainda, até o ano passado, nos programas de pós-graduação, porque os programas são independentes, eles são autônomos. Eles podem escolher a própria política e você discute na CPP. A CPP não iniciou esse tipo de discussão, então, e ninguém trouxe, então, por isso que não tem.

Entrevistador: $\mathrm{O}$ decanato realizou algum estudo acerca desse tema?

Entrevistado (E1): Não.

Entrevistador: Conhece algumas experiências, como a da Bahia?

Entrevistado (E1): Que você me falou.

Entrevistador: Quais as dificuldades institucionais para desenhar e implantar esse tipo de política?

Entrevistado (E1): Não teve dificuldade nenhuma, pelo menos os que implantaram, simplesmente, quando o edital foi aprovado, passou por aqui nós aprovamos, a CPP aprovou a abertura de vagas, sem problema.

Entrevistador: Mas, aí é que tá. Se o DPP tivesse essa iniciativa, gostaríamos de, é um assunto que está em debate, a gente tem um, está começando a aumentar o número de programas demandando, gostaríamos de curtir uma política institucional. Teria dificuldade? Você acha que sairia?

Entrevistado (E1): Alguns programas seriam reticentes. Eu acho que teria programa que sim e outros não.

Entrevistador: Mas se acontecesse poderia até colocado esse critério.

Entrevistado (E1): É. Existe essa possibilidade, você faz se você quiser. Já foi aprovado isso. Mas se for imposto.... 
Entrevistador: É uma coisa de estímulo. Nós gostaríamos de estimular, então, não temos uma política, programas, como vocês podem fazer? Vocês teriam alguma dificuldade ou isso é...

Entrevistado (E1): Não. Quem quiser fazer, sem problema nenhum. Vai haver essa discussão no fórum porque já foi levantada a bola pela associação de pós-graduandos essa discussão vai ocorrendo.

Entrevistador: Então, está em processo de discussão disso mesmo, parece que está caminhando para uma política institucional.

Entrevistado (E1): É. Porque começou agora, agosto do ano passado, um ano, ninguém se falava nada e essa é a pressão mais, como eu te falei, da área de humanidades.

Entrevistador: E aí deveria ter uma integração, então, como DPP que tem esses setores que avalia que devem estar integrados com a implantação de uma forma institucional.

Entrevistado (E1): O DPP o DAC, assunto comunitários, também, viram a necessidade...

Entrevistador: Pensaram na permanência, porque, provavelmente, um público carente economicamente.

Entrevistado (E1): Porque, as bolsas, como é que são distribuídas, você tem, a CAPES dá uma cota de bolsa chamada demanda social. Então, cada programa, tem um conjunto de bolsas, poucas bolsas, ele tem um regulamento. Então, você como programa de pós-graduação eu te dou essas bolsas e você tem que montar uma comissão de bolsas e você tem que escolher quem vai receber essa bolsa pelo mérito, mas se você fala que é pelo mérito, vamos supor aqui que o cotista passe lá em quinto lugar, sexto lugar, eu só tenho quatro bolsas. Mas quem precisa mais de bolsa são eles, não são os cinco primeiros e a CAPES pede que você use um mérito, então, a CAPES também tem que participar disso. Colocar um critério socioeconômico para, também, dar essas bolsas, porque o regulamento é meio fechado, mas a comissão de bolsas pode até aqui tentar não usar esse regulamento ou tentar colocar outros critérios, mas eu acho que deveria vir de cima, da CAPES falando critério socioeconômico.

Entrevistador: É. Porque se vocês são cobrados pelo critério da CAPES, realmente, é 
interessante que ela esteja envolvida. Quais as dificuldades encontradas do ponto de vista da população negra? Você tem esse feedback, assim, desses cursos, ainda não, não é? Aí eu teria que conversar com os cursos.

Entrevistado (E1): Teve já a defesa de um índio de um curso, se eu não me engano, de linguística. Porque o curso de linguística eles tem uma professora que é especialista em línguas indígenas, tem um professor bem antigo aqui, chamado Aron, que ele foi um dos primeiros a decifrar um monte de língua da Amazônia e ela era uma ex aluna dele, ela já tem mais de sessenta anos, no laboratório LIPS, se eu não me engano, de línguas indígenas e ela tem alunos indígenas da tribo que ela quer saber a língua, então, ele vai passar a língua que é apenas falada para o papel, fonema e tudo mais, tentar resgatar aquele língua e um desses índios teve sua tese aprovada recentemente esse ano.

Entrevistador: Negros, não?

Entrevistado (E1): Negros, tem. Um. O decano, misturado, não é negro, mas...

Entrevistador: Eu sou descendente de índio.

Entrevistado (E1): Negros você tem em todos os lugares, mas é esporádico, é pouco, eu não fiz aqui doutorado, eu fiz no exterior, mas você tem, sempre teve, mas em pequena quantidade. Você foi à Bahia fazer essa pesquisa?

Entrevistador: Não.

Entrevistado (E1): Tem que ir para lá.

Entrevistador: Não. Lá já está implantado desde 2004.

Entrevistado (E1): Mas você teria respostas para tudo isso.

Entrevistador: Mas, eu preciso ver o caso da Universidade de Brasília. As coisas particulares, as questões particulares. 
Entrevistado (E1): Por enquanto, não. Tem um embrião.

Entrevistador: É e tem uma característica aí que é institucional que está desenhando aí, parece, para uma política institucional.

Entrevistado (E1): E, talvez, o governo, como você mesmo falou que tem lá meta dele, ele pode baixar uma resolução, todo mundo vai ter que ter.

Entrevistador: Não tem.

Entrevistado (E1): Mas, como eu te falei, a Universidade, teoricamente, ela pode.

Entrevistador: É a 14.5, implantar ações para resolver as desigualdades étnicos raciais e regionais.

Entrevistado (E1): É. Mas isso ele não está obrigando ninguém. Ele pode obrigar em um decreto, a partir de agora tem que ter.

Entrevistador: Ainda não fez isso, não é? Mas é a programação de educação.

Entrevistado (E1): É, mas ele não está obrigando.

Entrevistador: É uma orientação.

Entrevistado (E1): Como eu te falei, as Universidades deveriam ter a tal da autonomia mesmo com dinheiro para usar onde quiser, mas não tem autonomia, tudo amarrado, você tem os auditores, a procuradoria jurídica e ninguém não deixa você fazer nada. Então, é uma autonomia vigiada.

Entrevistador: É isso. Tem mais alguma coisa que você queria que fosse acrescentada para essa pesquisa, para esse tema? Você acha interessante essa...

Entrevistado (E1): A minha opinião pessoal? Eu acho, dependendo da área não precisa, outras áreas, sim. Pelo menos do que eu vejo como coordenador por cinco anos, os processos 
seletivos sempre foram minoria negra, índio, quase nunca. Eu tenho um aluno de ascendência índia e ele era professor de Tocantins, da UFT. Ele teve bolsa do Bradesco dada pela bolsa Bradesco pela alfabetização. O Bradesco tem um sistema de dar bolsa para aluno carente, ele ganhou essa bolsa, era PM, fez Agronomia lá em Tocantins, depois foi pra Viçosa fazer mestrado e fez doutorado comigo aqui em Brasília. Hoje ele é professor de Tocantins já há uns cinco anos e a gente colabora com pesquisas em conjunto e tudo mais. Ele é cara de índio, aqueles índios do Xingu, a família grande parte, mas, é misturado, também, como a maioria de nós somos, ninguém pode dizer que é puro disso ou daquilo.

Entrevistador: Tá bom. Acho que eu me dou por satisfeita.

Entrevistado (E1): Você provavelmente gostaria que tivesse mais coisa, mas não tem.

Entrevistador: É. Mas foi bom perceber isso nessa entrevista. Obrigada.

Entrevistado (E1): De nada. 


\section{APÊNDICE 3}

\section{Entrevistado (E2):}

\section{Decana em exercício (2012-2016) da Administração Superior - Decanato de Assuntos Comunitários (DAC) da Universidade de Brasília.}

Entrevistador: Eu gostaria de entender o lado institucional da Universidade de Brasília com relação às ações afirmativas ao acesso de negros na Pós-Graduação stricto Sensu. E aí, eu já entendi lá com o DPP que não existe uma política institucional geral, assim como foi feito na Graduação que foi institucional primeiro e foi posta para as unidades acadêmicas. Lá não existe, porque eles entendem que não existe uma demanda desse nível que necessite de uma iniciativa institucional. De todo modo, existe todo o movimento e existem iniciativas das Universidades, de algumas unidades acadêmicas, como a senhora mesmo mencionou, Sociologia, Antropologia, Direito. E o DAC tem sempre acesso e contato com esse tipo de estudantes, de demandas. Então, eu gostaria de saber em primeiro lugar se já foi desenhado algum tipo de política de ação, de plano para estimular o acesso da população negra na Universidade de Brasília, nos últimos anos de 2004 a 2014, de forma institucional.

Entrevistado (E2): Tem várias políticas. Tem políticas no Decanato de Graduação, que eu acho que você deveria entrevistar o decano de Graduação, isso no que tange a Graduação. No que tange ao Decanato de assuntos comunitários, nós criamos em 2013 a Diretoria da Diversidade. Essa Diretoria da Diversidade ela tem quatro coordenações, uma delas é a coordenação da questão negra. A coordenação da questão negra dentro dessa Diretoria e do Decanato ela, justamente, ela fomenta ações institucionais para a Graduação e PósGraduação, então, por exemplo, a Pós-Graduação ela tem uma regulamentação, cada programa tem o seu regulamento e é muito aberto. Cada programa de Pós-Graduação que desejar ampliar as vagas, fazer reserva de cotas para negros em seus programas de PósGraduação eles tem uma autonomia para fazer isso, como alguns cursos de Pós-Graduação já o fizeram. Da parte do Decanato, nós recebemos as demandas, não tivemos demandas sobre esse aspecto de inclusão nos cursos de Pós-Graduação, mas nós temos demandas para as cotas, não só para as cotas, mas para a assistência estudantil extensiva, também, à PósGraduação. Então, nós não temos demandas, reinvindicações de vagas em cursos de pósGraduação. Nós temos demandas para esse estender a política institucional de assistência 
estudantil à Pós-Graduação. Agora, o DAC incentiva isso, não só incentiva as cotas para negros na Pós-Graduação como, também, aqueles Programas que assim deliberarem os seus colegiados de Pós-Graduação como, também, para acesso de estudantes indígenas com reservas não de vagas, mas de vagas dos processos seletivos. É assim que acontece. É uma coisa importante, uma política de inclusão social e a Diretoria que nós criamos aqui na nossa gestão vem ao encontro dessas políticas afirmativas tanto na Graduação, quanto na Pós. Então, nós temos a Diretoria da Diversidade, uma coordenação da questão negra, uma coordenação da questão indígena, uma coordenação dos direitos da mulher e uma coordenação das questões de diversidade sexual, orientação sexual, contra toda forma de violência nesse segmento da comunidade universitária. Então, a gente incentiva esse tipo de ação da parte dos programas que têm uma autonomia.

Entrevistador: Então, vocês fazem algum estudo a respeito desse tema?

Entrevistado (E2): Não. Do tema sim, das cotas, mas não centrada na Graduação ou PósGraduação. Atualmente a gente está fazendo um levantamento de todas as linhas de pesquisa sobre essas quatro áreas da Diretoria da Diversidade, todas as linhas de pesquisa, os temas que são trabalhados, o que une isso? Gênero, etnia e raça, inclusive para ver as lacunas de pesquisa que tem nesta área da diversidade, gênero, etnia e raça para que a gente possa fomentar, fazer seminários, pesquisas, incentivar algum outro tipo de política. Essa Diretoria é nova, ela vai fazer dois anos agora, então, a gente está em uma fase mais de prospecção.

Entrevistador: Você tem conhecimento de outras Universidades que têm um modelo para a Pós-Graduação?

Entrevistado (E2): Não, porque isso é uma iniciativa, eu não fiz esse levantamento ainda, mas a Universidade de Brasília é sempre vanguarda dessas áreas, então, eu creio que se tiver são muito poucas. Porque essa pesquisa que você está fazendo é ligada muito a área acadêmica; ensino, pesquisa e extensão. A gente aqui cuida das ações afirmativas no âmbito da comunidade Universitária, agora, ensino, pesquisa e extensão tem os três Decanatos que são ligados a missão institucional em ações finalísticas da instituição, então, a gente concentra mais nessa parte de políticas afirmativas na perspectiva do direito e cidadania e de inclusão. E essas ações são muito vinculadas à área acadêmica. O Decanato é tido como uma área meio, há uma discussão sobre isso, também, se o Decanato seria área meio ou não. Eu acho que 
deveria ser, um Decanato acadêmico ele é transversal, o que nós estamos fazendo é transversal a todas as ações de ensino, pesquisa e extensão.

Entrevistador: Porque quando eu perguntei para o professor Fabrício da Sociologia de que forma quais outras áreas que podiam ajudar, lá eles mencionam o DAC, porque eles têm o incentivo e tem a população carente que precisa de uma assistência estudantil que seria por aqui.

Entrevistado (E2): Mas eu acho que a sua pesquisa ela não centra na questão da carência em si, da pobreza, ela centra na questão da inclusão, do acesso à população negra, de uma maneira geral. Então, ela tem outro viés, mas aqui, por exemplo, o Programa Afroatitude que nós temos na Graduação é para estudantes em situação de vulnerabilidade socioeconômica e que sejam negros e negras que tem acesso a esse programa da Graduação. Na Pós-Graduação não tem esse programa, porque os estudantes têm bolsas da Capes, do CNPQ, então, já tem formas de fomento específicas para a Pós-Graduação e não pode haver acúmulo de bolsas. Na Pós-Graduação, se ele recebe uma bolsa de Pós-Graduação não pode ter acúmulo nenhum com outro tipo de bolsa.

Entrevistador: Então, no entendimento da senhora, esse tipo de política tem que ter uma integração entre as áreas para ser eficiente?

Entrevistado (E2): Para ter uma política institucional, para a Pós-Graduação ela tem que ser pensada pelos Decanatos sim, com o Decanato de Assuntos Comunitários. O grande problema da não inclusão ainda da assistência estudantil para a Pós-Graduação é falta de recursos. A assistência estudantil hoje ela é financiada pelo Governo Federal, exclusivo para a Graduação, tem um decreto presidencial, é uma política de governo, ainda não é uma política de Estado, mas na pós-Graduação não há nenhum ainda recurso destinado para ampliar a assistência estudantil para a Pós. Então, essa discussão, também, de ampliar as cotas para a Pós, ela é muito recente, eu acho que aconteceu no movimento, o seguinte: Primeiro a UnB vanguarda dez anos consolidando essa política que é muito avançada na Graduação para depois você então ampliar para a pós-Graduação. Eu acho que esse é o movimento.

Entrevistador: E tem no governo o novo Plano Nacional de Educação, ele colocou uma meta lá que prevê, que pede aumento de percentual de inclusão de acesso de alunos na Pós- 
Graduação Stricto Sensu. Então, está surgindo, realmente, de vários lugares.

Entrevistado (E2): Eu acho que isso vai atender não só porque é uma meta do governo, mas é porque é um movimento importante de sociedade desse resgate dessa dívida social com a população negra afrodescendente brasileira.

Entrevistador: Então, a dificuldade, o desafio encontrado para fazer a assistência estudantil na Pós-Graduação é, justamente, não existir uma política de Governo, de Estado e aí desencadeia em recurso.

Entrevistado (E2): Não tem política para a pós-Graduação, o fórum de pró-reitores de assuntos comunitários é favorável a essa política, mas com dinheiro novo. Porque o que nós temos hoje de recursos para a Graduação não é suficiente para atender a todas as demandas, qualificada por assistência estudantil, em termos de recursos. Então, hoje a gente atende, digamos assim, trinta por cento da demanda por assistência estudantil na Graduação com o recurso que vem do MEC. Nós somos favoráveis, achamos que é legítimo uma assistência estudantil para a Pós-Graduação, como política de transferência de renda, porque a política de mérito está na própria Pós-Graduação pelos critérios de investigação de bolsas acadêmicas para Mestrado e Doutorado. A discussão tem que ser por mérito, é o que nós temos no diferencial, também, na assistência estudantil na Graduação, uma coisa é o mérito do estudante em relação a PIBIC, a Iniciação Científica, ao PIBEX, então, ele concorre pelo mérito. Na assistência estudantil ele concorre pela necessidade. Por isso que a gente chama de uma política de transferência de renda com o benefício de permanecer e se titular com sucesso, pelo menos minimizando as desigualdades sociais existentes dentro da própria Universidade.

Entrevistador: Além dos Decanatos fins, quais Decanatos que você acha, ou áreas que tem que estar ligado, integrado, além do DAC?

Entrevistado (E2): Ensino, pesquisa e extensão e o DAC. Os demais são muito específicos, gestão de pessoas já é uma outra questão, planejamento é assimilar os recursos para isso, se for o caso, e DAF para personalizar as bolsas, ou esse acesso. Mas, na Universidade é o DAC com os três Decanatos da missão finalística da instituição. 
Entrevistador: Quais mudanças institucionais você considera que são importantes para que ocorra essa ampliação efetiva?

Entrevistado (E2): Eu acho que, aquilo que eu estava falando para você, existe um posicionamento no Fórum Nacional de Corretores de Assuntos Comunitários Estudantis, isso já está na agenda desse fórum junto a ANDIFS. Mas esse debate ainda não começou nas Universidades. É um debate que o fórum quer levar para as Universidades. Nós vamos ter um encontro agora, essa semana, com certeza isso vai começar a ser discutido mais fortemente, as próprias Associações de pós-graduandos das Universidades nós tivemos um encontro, esse primeiro semestre aqui em Brasília, vieram quarenta associações de pós-graduandos colocar isso na agenda pública. Fizeram reuniões com o MEC, com a Capes, com a ANDIFS, então, eles estão se mobilizando em torno dessa agenda. Que ela se torne, também, uma agenda pública governamental. Então, depende muito desse movimento que já está encampado pelo $(12: 56)$.

Entrevistador: Os programas de Pós-Graduação eles têm autonomia para definir.

Entrevistado (E2): E esse movimento já começou.

Entrevistador: Me parece que está acontecendo é um movimento dos dois lados.

Entrevistado (E2): É. Dos estudantes e dos programas.

Entrevistador: Os programas começaram já até a implantar e, também, tem esse movimento, que eu não sabia, dos...

Entrevistado (E2): Dos pró-reitores e das associações de pós-graduandos. Eu acho que um aluno que você deveria entrevistar era o nosso estudante da APG daqui, Associação de PósGraduandos, é Gabriel, eu vou te dar o telefone dele. A professora Marcela (13:43) ela é de cotas para índios na Antropologia, não é para negros, é para índios, mas é o estudante da PG que pode te dizer todo esse movimento da parte dos estudantes, por assistência estudantil e também por cotas para negros, os programas de pós-Graduação.

Entrevistador: E vocês como DPP estão abertos, também, para essas demandas se surgirem, só 
que não surgiu, não chegou.

Entrevistado (E2): Não chegou aqui para nós, mas nesse seminário que houve aqui das APGs, foram quarenta que vieram, eles chegaram a colocar essa questão, mas a agenda principal deles, no momento, ela é econômica. É a assistência estudantil, porque aumentou muito o número de estudantes de Pós-Graduação que só vivem com a bolsa. Com a bolsa que é de mérito e essa bolsa, muitas das vezes, ela não dá para moradia, alimentação, ela é muito mais, ao invés de ser uma bolsa para ele fazer a pesquisa de Mestrado e de Doutorado é uma bolsa de manutenção do próprio cotidiano, são questões básicas, necessárias, de funções básicas necessárias do cotidiano de cada ser humano. Então, essa discussão ela é muito importante e ela vai na esteira dessa discussão, também.

Entrevistador: É isso.

Entrevistado (E2): Espero ter contribuído pouquinho. Vou pegar o telefone do Gabriel para você e veja com a sua professora do programa essa questão do Código de Ética, porque se o Comitê de Ética e Pesquisa sabe que está fazendo isso, eles podem solicitar ou procurar adequações no atendimento ao protocolo. Tem núcleos de ética agora e pesquisa das Universidades. 


\section{APÊNDICE 4}

\section{Entrevistado (E3):}

\section{Coordenador em exercício do Programa de Pós-graduação Stricto Sensu em Sociologia (PPGSol), do Departamento de Sociologia (Sol), ligado à unidade acadêmica Instituto de Ciências Sociais (ICS) da Universidade de Brasília.}

Entrevistador: Eu sou lá do Programa de Pós-Graduação em Gestão Pública da FUP. Já ouviu falar?

Entrevistado (E3): Eu conheço a Universidade eu não sabia que tivesse esse curso.

Entrevistador: Tem, lá na FUP, lá em Planaltina. E aí a minha dissertação o tema é ações afirmativas para aumento ao acesso da população negra em Programas de Pós-Graduação Stricto Sensu e aprofundando a questão na Universidade de Brasília, porque a gente tem dez anos de experiência em Graduação e Pós-Graduação eu até achava que não tinha na Universidade, na minha experiência, mas descobri que tem. E a Sociologia foi a primeira?

Entrevistado (E3): Foi a primeira de Pós. De Graduação a gente aderiu quando a Universidade aderiu. Como você está dizendo, já faz dez anos.

Entrevistador: Dez anos. Foi de forma institucional, não foi?

Entrevistado (E3): Institucional.

Entrevistador: A iniciativa foi da Universidade de forma institucional e as unidades acadêmicas aderiram.

Entrevistado (E3): Mas, de alguma forma, a Sociologia, eu não tinha chegado aqui, mas eu sei que ela contribuiu com a proposta, foi um dos departamentos que, de alguma forma, pressionaram...

Entrevistador: O professor Carvalho de Antropologia que escreveu sobre a primeira proposta...

Entrevistado (E3): Isso. O Zé Jorge que é muito ativo.

Entrevistador: Até citei ele na minha pesquisa, na dissertação. Interessante o ponto de vista dele.

Entrevistado (E3): Grande pesquisador que foi muito importante para esse tipo de ação. 
Entrevistador: Aí eu estou fazendo o seguinte, é um relatório técnico, não tem juízo de valor, eu vou levantar a situação atual e fazer recomendações, conclusões, etc. Então, eu queria começar perguntando como foi a iniciativa de vocês para incluir esse curso na reserva de vaga?

Entrevistado (E3): A coordenação anterior, na figura do professor Marcelo Rosa, ele chamou para um seminário todos os professores do departamento, não só do programa e, naquele seminário, ele propôs que se fizesse uma reserva de vagas para estudantes negros e negras. Essa reserva de vaga ficou em trinta por cento, o Mestrado hoje são duas vagas, no Doutorado hoje são três vagas. Houve, na verdade, no ano passado um aumento dessas vagas devido ao fato de que no ano passado não foram selecionados estudantes estrangeiros para cursar a Sociologia. Então, sobraram duas vagas de Mestrado e duas de Doutorados que tão logo a gente soube do resultado foram incorporadas as vagas universais e, dessas vagas incorporadas, uma foi para ação afirmativa e a outra foi para o edital universal, tanto Mestrado quanto do Doutorado. Isso foi ano passado, então, voltando um pouco, nesse seminário o departamento fechou uma proposta desse seminário, se eu não me engano foi em 2012, fechou uma proposta para trabalhar no edital que contemplasse ações afirmativas. Se eu não me engano quem trabalhou nesse edital foi o professor Marcelo Rosa, o professor Joaze Bernardino, o professora Aide Caruso e outros colegas também que eu vou está fazendo uma injustiça.

Entrevistador: Seminário sobre ações afirmativas gerais?

Entrevistado (E3): Não só sobre ações afirmativas. Foi um seminário sobre o Programa de Pós-Graduação e a proposta que eu considerei, que eu considero no momento mais avançada era essa proposta de ação afirmativa que é inédita no Brasil, parece que os cursos começaram concomitante a implantar isso aqui na UnB e, também, no Museu Nacional no Rio de Janeiro, eu sei que agora eles estão fazendo isso. Junto com isso veio o formato que o edital deveria ter, então, nós reduzimos a nota de corte para classificação de sete para cinco. E por que que nós fizemos isso? Alguns estudantes, em geral pobres, e aí não tem a ver com brancos ou negros, eles, de alguma forma, tinham dificuldades em algumas fases. Ele tirava, às vezes, no dez no projeto, mas ia para uma entrevista, dada a condição social a que ele experimentou em vida e o seu corpo aparentava uma certa insegurança e dificuldade, às vezes, de encarar uma banca de seleção. Então, nós resolvemos baixar essa nota para cinco para que a pessoa pudesse chegar ao fim do processo seletivo e, somente ali, se fizesse a conta, se ele teria ou não alcançado nota para ser aprovado.

Entrevistador: Mas isso independente de ser negro ou branco?

Entrevistado (E3): Isso. Para todo mundo todo mundo baixou a nota.

Entrevistador: Foi subjetivo, não é, que é a entrevista? 
Entrevistado (E3): Na verdade, o que que acontece? A gente achava que a entrevista ela abaixava muito a nossa dos candidatos, isso negros e brancos também, então, uma maneira de mantê-los ainda concorrendo no processo, nós abaixamos a nota pra que eles tivessem chance de chegar até o fim no processo seletivo. Só que aí tem que notar o seguinte: Mesmo abaixando a nota de corte, ainda vão ser classificados somente estudantes melhor classificados no processo como um todo. Então, por exemplo, na última seleção, o último candidato que entrou que, no caso, era um aluno de fato participando de ações afirmativas ele entrou com seis ponto oito que a gente considera uma nota satisfatória para entrar na Universidade, na Pós-Graduação. Então, a gente não viu prejuízo nenhum para o processo seletivo ter rebaixado a nota. Fizemos um monitoramento do semestre passado para ver como é que a turma, que somente iniciou seu curso agora com estudantes que participaram de ações afirmativas estava sendo avaliada pelos professores e, de uma maneira geral, os professores acharam a turma bastante boa, turma que corresponde aos critérios de excelência que nós somente esperamos de alunos de Pós-Graduação, quer dizer, a turma já não demonstrava mais diferença entre alunos que participaram de edital universal ou alunos que participaram de editais de ações afirmativas.

Entrevistador: Então a qualidade é a mesma?

Entrevistado (E3): É a mesma. E, às vezes, até alunos de ações afirmativas eles tem o rendimento muito melhor de que outros alunos.

Entrevistador: Então, de repente, esses alunos nem precisariam da reserva para fazer...

Entrevistado (E3): Na verdade, talvez eles precisariam porque a gente tem que entender que alguns estudantes brancos tiveram notas superiores a eles e, por não haver reserva de vagas, eles entrariam, e não entrariam os negros.

Entrevistador: Então, na seleção de forma geral, os brancos tiveram resultado melhor do que os negros?

Entrevistado (E3): Não. Inclusive a primeira colocada na ação afirmativa teve a primeira nota de todo o edital, quer dizer, tem esse elemento que tem a ver com, que eu acho que explica muito porque que a Universidade brasileira e pública é, antes de tudo, uma Universidade branca. É porque você, de fato, ainda tem condições sociais profundamente desiguais e, em função disso, você tem muita dificuldade de recrutar alunos e alunas não brancos.

Entrevistador: E acaba que existir a reserva de vagas é um estímulo, não é? De repente, esses alunos negros não iriam para a seleção se não tivesse essa reserva.

Entrevistado (E3): Isso. A gente considera um atrativo a mais para que eles se interessem pelo programa. 
Entrevistador: Eu conversei com o professor Bergman, que é o diretor atual do DPP, e não existe um incentivo institucional, assim como houve na Graduação que o movimento institucional para as unidades e aqui não, para a Pós-Graduação não existe. Até há o entendimento de que existem cursos ou algumas unidades que nem precisa, nem tem demanda para ter uma reserva de vaga.

Entrevistado (E3): Eu não acredito nisso. Eu acho que se você fizer o edital com a reserva, você vai atrair estudantes. E tem que entender o seguinte: Ainda no Brasil o estudante negro se sente intimidado com a Universidade pública. Isso é uma realidade, porque eu vim de uma comunidade extremamente carente do Rio de Janeiro e todos os meus colegas negros, mais capazes do que eu, desistiram de seguir carreira no meio do segundo grau, etc. E, no meu caso, por vários motivos eu pude seguir a carreira. Se criar um incentivo você vai ter, de alguma forma, a demanda. Se ele diz que não tem demanda, eu acho que não tem demanda, porque não tem edital.

Entrevistador: É porque diz que tem cursos muito específicos, alguns cursos muito específicos, microbiologia, não sei o que lá, de T.I, talvez, que já é auto seletivo, poucas pessoas procuram por isso, então, um professor ele já consegue identificar se o aluno, independente de cor, se ele tem a qualidade para seguir na vida acadêmica.

Entrevistado (E3): Mas eu acho que não é só uma questão de qualidade. Eu acho que é uma questão de entrada, de acesso. Eu não sei como é que é essa identificação de quem tem ou não qualidade. Eu acho que quem tem que medir isso é o processo seletivo. Não tem nenhum tipo de professor com essa capacidade que eu considero quase fantasmagórica de identificar quem é que pode ou não. O processo seletivo, como eu disse, ele é muito intimidador para muitos tipos, vamos dizer assim, de indivíduos e eu acho que entre eles é intimidador para os indivíduos negros que não consegue se reconhecer no tipo de Universidade que nós temos, uma Universidade evidentemente branca. Se você for olhar os dados é mais ou menos isso que ocorre. A grande questão é: Se você tem pouca demanda em um curso pode ficar sabendo que essa demanda é contemplada com estudantes brancos e que tem condições financeiras de se manter em um curso universitário. Se você cria possibilidades de o aluno negro concorrer, eu digo como? Com editais atrativos, com condições socioeconômicas para que eles se mantenha, eu acho que a gente vai atraindo um público tão capaz como esse que tem hoje na Universidade pública.

Entrevistador: Então, talvez, se isso fosse uma política institucional, de repente, evidenciaria isso aí que você está falando.

Entrevistado (E3): Isso, perfeito, é isso mesmo. Aqui, só para te adiantar, a gente começa a distribuir bolsas com alunos cotistas, depois a gente segue com os alunos universais.

Entrevistador: Na Pós-Graduação? Porque eu estava olhando os editais de permanência lá do 
DAC, só tem Pós... Não, tem de moradia Pós-Graduação, não é? Mas...

Entrevistado (E3): Tem também moradia, mas nós damos a bolsa de estudos que nós temos, bolsa de Mestrado e Doutorado com preferência para esses estudantes. Claro que até agora nós tivemos um número até razoável de bolsas, uma parte dos estudantes, inclusive estudantes que entraram com ações afirmativas eles têm trabalho, então, abriram mão da bolsa, então, estão se mantendo com o salário do trabalho deles, mas a gente tem essa política de começar a ver os alunos cotistas para que eles, de alguma forma, tenham meios de se manter aqui. Mas é claro que isso pode ser depois aprimorado, talvez, com chamadas através de mecanismos de análises socioeconômicas da condição até do aluno que entra com ações afirmativas.

Entrevistador: Então vocês seguem mais ou menos o modelo que a Universidade pratica, não é?

Entrevistado (E3): Aparentemente sim.

Entrevistador: Que é fazer o edital com reserva de vaga, com essa série de critérios que você falou e, também, tem um apoio para a permanência no curso, mas isso não é apoiado nem é estudado, nem acompanhado pelo CPP, nem pelo DAC? É uma iniciativa totalmente daqui?

Entrevistado (E3): Daqui. A gente, sempre em reuniões do DPP, bate nessa tecla, claro, da importância de se ter ações afirmativas na Pós como um todo, inclusive isso é uma política do Governo Federal para suas Universidades e até agora é muito humilhante o Governo, um Estado que dá condições somente a uma parte da população e que é uma parte minoritária ainda.

Entrevistador: É, o novo Programa Nacional de Educação tem uma estratégia lá que...

Entrevistado (E3): Tem. Para implementar isso, eu acho que vai ser uma questão política muito difícil.

Entrevistador: O Bergman falou da autonomia universitária. O governo lança meta, mas a autonomia universitária permite que ele adote isso ou não. Não há uma política, é uma meta que ele lança...

Entrevistado (E3): Mas isso, também, é relativo. Claro que esse governo que está aí ele apoiou as ações afirmativas, me parece que isso é até programático do partido no poder e para a Pós também. Eu não sei se hoje a presidenta tem condições política de implementar isso, mas, de alguma forma, parece que já está sendo discutido no MEC e em outros órgãos que cuida do ensino superior.

Entrevistador: Aí a gente consegue entender, então, a relação da iniciativa de vocês com a Instituição UnB que seria o DPP e DAC. Tem mais alguma área que poderia ser envolvida de 
forma institucional para apoiar os programas?

Entrevistado (E3): Tem. No caso, eu acho a Reitoria, como um todo, tem que se empenhar em um programa como esse, isso não pode ser ação isolada, tem que ser um programa institucional da Universidade e eu quero ver o dia que a Pós-Graduação, por exemplo, de Medicina, que é algo extremamente especializado possa, também, incorporar esse tipo de ação afirmativa, em Engenharia, em outras áreas que tem uma demanda, em geral, muito (31:08). Então, a gente acha que com apoio de uma Reitoria que tenha, de fato, uma ação claramente mais igualitária, no sentido das condições raciais no Brasil, eu acho que isso ia ajudar muito para que se expandisse ainda mais e que se fizesse jus ao termo Universidade para se incorporar as distintas classes, raças, credos, gêneros, etc.

Entrevistador: E a relação? Como você vê o impacto disso, então, na Universidade dessa implantação do Programa, dessa reserva de vaga do Programa? Na Sociologia, então, não teve impacto em termos de qualidade, de produção, de qualidade nas disciplinas, porque até agora o que vocês conseguem monitorar é só isso, não é? A qualidade nas disciplinas, porque não tem dois anos de curso ainda para ter o...

Entrevistado (E3): Eles entraram esse ano, é muito cedo ainda afirmar o que vai ocorrer, talvez seja melhor a gente analisar isso ao fim de um ciclo de Mestrado, um ciclo de Doutorado, após isso que a gente vai poder fazer uma análise mais detalhada das condições de entrada e as condições de saída. Mas, se a gente pode analisar uma turma no que ela apresentou, essa turma não difere em nada de turmas anteriores, das melhores turmas que a gente teve, ou seja, manteve o nível de excelência que a gente espera.

Entrevistador: Então, o impacto dessa reserva foi, não houve em termos de qualidade?

Entrevistado (E3): Em termos de qualidade não houve, não decaiu até agora, mas tem impacto em termos de justiça racial, ou seja, a turma ela está mais heterogênea em termos de cor. Não é mais uma turma profundamente caucasiana como as Universidades do Brasil aparenta.

Entrevistador: E é uma resposta social, não é?

Entrevistado (E3): É uma resposta exatamente, uma demanda que está vindo da sociedade. É por isso que eu falo que a autonomia da Universidade é relativa, ou seja, a Universidade serve para responder às demandas que a sociedade coloca para ela. Nenhuma dessas demandas hoje tem a ver com justiça étnico racial no Brasil. Agora, a Antropologia incorpora, também, inicialmente indígenas, na Graduação tem uma série de políticas também que eu considerei inicialmente interessante para fazer valer esse princípio de justiça.

Entrevistador: E vocês tiveram dificuldade para implantar esse curso?

Entrevistado (E3): Não. Parece que foi quase um consenso aqui e deve ser tipo uma ou outra 
voz que colocou questões mais pontuais sobre o edital, sobre como seria isso, mas em termos de um consenso parece que foi consensual essa proposta. É claro que mais cedo ou mais tarde ocorrerá alguns ajustes no edital, talvez a nota possa subir, a nota de corte de cinco para seis, porque ele está começando agora, está ocorrendo agora pela segunda vez o processo seletivo, pode ser que isso altere no futuro, mas, até agora, os colegas também avaliam como uma política bem sucedida.

Entrevistador: Não existe nenhum desafio para frente, então, está indo tranquilo. Foi implantada de forma tranquila e não tem desafios ainda para vencer não, então...

Entrevistado (E3): Isso. Eu considero assim, tem alguns desafios, a gente quer expandir mais o acesso de pessoas que não estão em Brasília ou que não estão em Goiás, por exemplo. A gente quer ir para mais localidades do Brasil para que outros estudantes negros pudessem fazer o processo seletivo, já que a UnB é uma das, já que a Sociologia é um dos únicos cursos de Pós que oferece isso. Esse é um desafio que a gente tem se colocado também: Como fazer. Mas a gente sabe, tem muitas dificuldades para esse tipo de estudante, por exemplo, condições financeiras de pegar um avião e de fazer o processo seletivo já que é presencial, e tem o elemento econômico de como se manter em Brasília, as pessoas em geral se assustam muito com o custo de vida em Brasília. Então, a gente está tentando algumas outras ações que pudessem encorajar estudante de fora do Distrito Federal a vir, também, fazer o processo seletivo, talvez seja o principal desafio que a gente tem atualmente.

Entrevistador: Vocês tem um feedback de como a CAPES vê essa iniciativa ou não tem nenhuma relação?

Entrevistado (E3): Recentemente, a fundação, foi a SEPIR, Secretaria de Políticas para a Igualdade Racial pediu para a gente informações sobre o processo seletivo. Nós encaminhamos, eu fiz um relatório sobre como ocorreu o processo seletivo, o número de vagas, quem são as pessoas, etc., e a gente não divulga os nomes, a gente não divulga quem é que participou de um processo e quem participou de outro processo. Quer dizer, isso demonstra que isso teve algum tipo de visibilidade, pelo menos para esse tipo Secretaria. Agora, de fato, para a CAPES, como coordenador do curso eu tenho que participar das reuniões de avaliação da Pós-Graduação no Brasil, toda reunião de avaliação eu coloco o critério de justiça distributiva, igualitária, etc., como um dos critérios para avaliar a PósGraduação no Brasil também.

Entrevistador: E não existe esse critério, não é?

Entrevistado (E3): Não existe. Existe lá em termos qualitativos que não conta nada para a avaliação do programa, então, tem outro propósito, também, um programa como esse de ação afirmativa, a gente espera que possa surgir, digamos assim, na Universidade autores competentes em questões mais específicas que, em geral, são negligenciadas como o pensamento negro no Brasil, como temáticas ligadas a temática étnico-racial, etc., então, tem 
esse objetivo também, além de objetivos mais de justiça social tem, também, esse objetivo de ter um maior número de trabalhos que possam desenvolver essas temáticas em específico. Até agora, os estudantes que entraram, não todos, tem desenvolvido teses que tem a ver com questões raciais que para a gente cumpra um pouco das expectativas, também, desse tipo de reserva de vagas.

Entrevistador: Como que foi a influência do movimento negro para a iniciativa da criação dessa reserva de vagas no programa?

Entrevistado (E3): De fato, isso é uma demanda que ocorre esporadicamente, alguns estudantes aqui sempre reivindicaram isso, da Pós, alguns estudantes da Graduação reivindicaram, alguns coletivos reivindicaram. Tem agora aqui no departamento um coletivo de estudantes negros que, de alguma forma, participa bastante na manutenção da política contra qualquer tentativa de... Na verdade, nunca houve uma tentativa, mas eles já se prepararam para caso haja uma reação contra em algum momento, eles possam se organizar para impedir isso, aí tem discutido essas questões todas na própria reunião do colegiado, no sentido da manutenção do Programa. Então, que dizer, são esses grupos ligados, também, a causa da negritude no Brasil tem participado ativamente, agora, da manutenção da ação afirmativa, antes da criação, agora da manutenção da ação afirmativa. Eu acho que isso é importante com esses riscos conservadores que o Brasil está passando hoje, uma hora para outra você baixa um decreto proibindo isso, você tem que ter um grupo organizado para defender.

Entrevistador: E parece que hoje o cenário é favorável.

Entrevistado (E3): Isso. Houve um retrocesso, mas é favorável. Por exemplo, um Eduardo Cunha não é mole, um cara desse querer, mais cedo ou mais tarde, o poder que tem, criar uma lei e essa lei ser votada e ele cancelar o que foi votado e voltar de novo até ser aprovado é pouco possível.

Entrevistador: Não dá para duvidar mesmo de nada, não.

Entrevistado (E3): Ultimamente a gente pode acreditar em tudo que tem acontecido, enfim.

Entrevistador: Tem um lado que é a própria pessoa negra ter preconceito e não se colocar em uma seleção de reserva dessa, até porque existe todo um preconceito em volta. Você percebe que isso acontece aqui? Os alunos são inibidos ou não?

Entrevistado (E3): Não. Pelo menos aqui há, na verdade, uma organização entre estudantes negros, como eu estou falando de alguns coletivos que militam em DCE, etc. e essa organização ela cria um certo encorajamento, um engajamento com a causa que transforma a participação em ação afirmativa como uma questão ligada a sua própria auto estima, sua própria auto imagem, ou seja, eu ajudei a construir isso e eu quero manter isso. Para manter 
isso eu tenho que criar demanda também, então, ele se envolve profundamente nisso como uma questão de identidade. Afinal, a negritude foi escondida pelo Brasil, tentou-se esconder a negritude desde muito tempo e a gente sabe que isso é uma questão de identidade, ou seja, a negritude tem que ser afirmada e reafirmada em cada momento, em cada meio, em cada espaço em que ela possa aparecer e eu acho que os estudantes têm muita consciência disso e eu acho que eles estão fazendo por onde em relação a esse tipo de...

Entrevistador: Esses estudantes eles vem da Graduação?

Entrevistado (E3): Muitos deles sim, outros de outras Universidades que vem participar, se sentem, como eu disse, encorajadas mesmo as Universidades que não tem o mesmo prestígio da UnB e que vem participar sabendo que essa é uma chance agora de eles estarem participando em igual condição com os alunos que, historicamente, entraram Só para completar em relação a isso, é claro que discriminação é um sistema de classificação, não importa o que você é, por exemplo, discriminação de gênero não importa se você é homem ou mulher, você acaba sendo apanhado por esse tipo de sistema discriminatório e você opera, às vezes, sendo mulher contra outras mulheres, etc., ou contra si mesmo desencorajando você de certas coisas que deveriam ser universais. Eu acho que no caso dos estudantes negros essa ação afirmativa traz um elemento de encorajamento e que está ligada à sua própria identidade, ele se sente ali contemplado e ele quer manter, na verdade, a ação afirmativa como uma forma de reforçar a sua identidade também.

Entrevistador: Desde que ele tenha essa identidade.

Entrevistado (E3): Desde que ele assuma isso. Isso é importante também, porque, às vezes, essas políticas que foram implementadas há muito tempo no Brasil de apagamento da identidade negra da cultura do Brasil dos corpos, as pessoas tentando embranquecer, etc. elas hoje eu acho que sofreram com o retrocesso por causa do engajamento negro, pode-se colocar aí desde a década de setenta, na verdade, em que esse engajamento tem feito, eu considero, um bem muito grande ao país na medida em que apresenta o Brasil como um país identitariamente plural, embora não racialmente democrático. Ou seja, na medida em que aparece a identidade negra, aparece o quanto ela é discriminada, o quanto ela é, de alguma forma, apagada frente a outras formas de identidade, e a principal dela é a identidade do branco, caucasiano que se acha, nem é nascido em Miami, nem Europa ou em qualquer outro lugar branco do mundo.

Entrevistador: Lá na Bahia eles implantaram na Pós-Graduação, desde 2002, a implantação de cotas foi na Graduação e Pós-Graduação, em todas as unidades, foi de forma institucional.

Entrevistado (E3): Na Pós, também?

Entrevistador: Na Pós, também. 
Entrevistado (E3): Mas na Federal?

Entrevistador: Não, na Estadual. Federal, não.

Entrevistado (E3): Na Federal, me parece que os dois primeiros cursos, na Federal do Rio de Janeiro, no Museu Nacional, e os cursos aqui de Antropologia e Sociologia.

Entrevistador: E agora aqui, também, tem Direito. Direito tem uma e tem a outra... Não me recordo, são quatro cursos, mas o primeiro foi daqui.

Entrevistado (E3): Serviço social, não?

Entrevistador: Direito, Antropologia é da Andressa, não é?

Entrevistado (E3): Não, é a Andréia.

Entrevistador: Fabrício, Direitos Humanos e Cidadania, da Sociologia, Andréia, Juliano Zaiber.

Entrevistado (E3): Juliano é do Direito.

Entrevistador: Tem dois do Direito.

Entrevistado (E3): Eu sei que o Juliano é do direito. Isso é bom, eu acho que, na verdade, isso vai crescer, não vai parar por esses cursos e nem vai parar na UnB. Eu acho que a tendência é, cada vez mais, corrigir essa injustiça histórica na Universidade ...

Entrevistador: Como que faz, por exemplo, uma unidade acadêmica aqui em Sociologia e outra na própria Universidade de Brasília não...

Entrevistado (E3): Eu acho que tem a ver com condições próprias do departamento. Tem departamentos que são conservadores mesmo, eles assumem essa identidade conservadora e eles tem muita dificuldade de aceitar isso como uma política. Outra coisa, às vezes, eu acho que é menos dramático quanto isso que é, na verdade, iniciativa, falta alguém, talvez...

Entrevistador: Até o movimento negro não ser tão forte naquela unidade...

Entrevistado (E3): Também. E pela iniciativa, também, a gente que participa de administração de Universidade, a gente sabe a quantidade de afazeres que os colegas também assumem. Agora, tem uma coisa por traz da não iniciativa, é que de fato há o esquecimento dos negros no Brasil, esses esquecimentos faz com que a pessoa não tenha iniciativa. Aqui, felizmente, você se lembrou desde, eu acho que se lembra há muito tempo a partir de uma simples observação que é a cor da salas de aula que são brancas e, a partir disso, esse reconhecimento 
de que não tem ali contemplado outras formas identitárias negras e outras formas étnicas aí houve a iniciativa de criar as ações afirmativas. Nos departamentos eu acho que, por causa dessa política de esquecimento, eu acho é muito comum as pessoas não se engajam, não têm iniciativa. Esse nível de racismo aí nesse caso ele é mais inconsciente do que propriamente consciente e, por isso, a importância de ter alunos negros, porque eles trazem a consciência daquilo que é tão somente inconsciente.

Entrevistador: O modelo que você acha ideal de reserva de vaga, ação afirmativa para PósGraduação? Se envolver a Instituição, no CAPES, dentro da UnB que estão envolvidas?

Entrevistado (E3): Tinha que ser assim: Uma política de Estado, para começar, com ações afirmativas, depois uma política de bolsa que tivesse como foco, também, ação afirmativa, CAPES e CNPQ, depois você tivesse nos núcleos Universitários, uma política também que fizesse uma pesquisa, um acompanhamento da real demanda por esse tipo de reserva de vaga e, finalmente, que você pudesse, dentro dos cursos em específico, criar condições, vamos dizer assim, para esses estudantes se organizarem entre eles e, também, que o curso se organize para dar condições de estudo, por exemplo, salas apropriadas, porque, muitas vezes, alguns, principalmente estudantes, não só brancos e negros, vem de comunidades carentes, então, sem condições de estudar que tenha, por exemplo, salas apropriadas. Então, isso tem que ser uma política de Estado e, finalmente, que isso possa chegar nos núcleos acadêmicos, nos núcleos universitários, expandir disciplinas, por exemplo, que trate de pensamento negro no Brasil, história dos negros no Brasil, etc., para também criar uma identidade mais consciente, vamos dizer assim, da posição que o negro ocupa na nossa própria história e identidade. Não adianta, por exemplo, que cursos de Engenharia não dê condições, por exemplo, de que esses alunos negros possam estar fazendo estágio em várias empresas. Sabemos que as empresas, às vezes, tem políticas raciais muito explícitas, não contratam negros, tem pesquisas que mostram isso, então, que elas possam de forma que o curso possa se engajar para arranjar essas vagas de estágio.

Entrevistador: Para transformar o mercado para que aceite...

Entrevistado (E3): Isso. Para que aceite esses indivíduos. Então, quer dizer, a política é muito mais ampla obviamente, a gente acredita que a política afirmativa aqui no departamento de Sociologia, ela ainda é uma atitude, uma postura, vamos dizer assim, muito iniciante, tímida, mas a gente acredita que é desse tipo de esforço que pode aparecer processos mais amplos de mudança. Enfim...

Entrevistador: Muito interessante essa iniciativa. Tem mais alguma coisa que você gostaria de dizer para que eu pudesse elaborar aqui na minha pesquisa?

Entrevistado (E3): Eu acho que a sua pesquisa vai se enriquecer muito, também daqui... Você está fazendo Mestrado, não é? Daqui há um ano, dois, quando você estiver no Doutorado, porque aí você já vai ter dados, talvez, mais consolidados a respeito de como ocorreu o 
desenvolvimento dessa política. Mas, em termos de iniciativa, eu acho que até agora a iniciativa tem sido muito bem-vinda e bem sucedida de ações afirmativas.

Entrevistador: A pretensão da minha pesquisa é justamente isso. É um assunto que pouco se fala e que quase não tem iniciativa, pode-se dizer isso. Porque eu imagino, na Universidade Federal a quantidade de Universidades que tem, quantos cursos que têm na oferta? Então, é quase percentual zero, zero vírgula um, que tem oferta de reserva de vagas, então, é justamente começar a provocar uma discussão, porque é uma coisa muito incipiente ainda, essa meta acabou de sair que foi ano passado, as primeiras iniciativas de reserva vagas estão acontecendo a partir de agora, então, é um lançamento, está começando um movimento para aumentar, para ampliar.

Entrevistado (E3): O seu trabalho é muito relevante por causa disso, porque traz, também, visibilidade dessas políticas, eu acredito que tem Universidade que nem saiba que isso está ocorrendo, que está ocorrendo em alguns cursos de Pós-Graduação essa reserva.

Entrevistador: Essa informação dessa pesquisa....

Entrevistado (E3): Eu acho que sim.

Entrevistador: E a gente vai fazer artigo também.

Entrevistado (E3): Muito legal. É importante, porque aí divulga mais.

Entrevistador: E no artigo, a gente pretende usar, justamente, as iniciativas da Universidade de Brasília, o lado institucional, as iniciativas das unidades e CAPES, vê se consegue, porque, pelo o que eu estou percebendo, os cursos de Pós-Graduação são massacrados pela avaliação da CAPES e, normalmente, é numérico, tem fator qualitativo e tem o numérico e o numérico é alto. Você tem que ter muitas horas de aula, você tem que ter muitas publicações, tem que ter número e qualidade também.

Entrevistado (E3): Tem uma desconfiança em relação a capacidade desses estudantes cumprirem as regras da CAPES, por exemplo, terminarem dissertações em vinte e quatro meses e tese em quarenta e oito meses. Até agora, o que eles têm demostrado, é que eles são estudantes como outro qualquer. Essa desconfiança não se justifica.

Entrevistador: Mas, assim, é uma questão social, se o próprio Governo já está demandando, não tanto uma política de Estado, mas tem uma meta, pelo menos no plano de educação. Se já tem até iniciativas da Universidade acontecendo, então, como isso se reflete na CAPES? Não há uma desconfiança também de que, pelo menos nos estudos, a nota lá, o IRA dos estudantes, no estudo de dez anos de experiência da Universidade de Brasília, os estudantes de Graduação eles tem o IRA mais baixo, pouca coisa, mas tem. Então, esses estudantes negros, baseado nos estudantes daqui, eles já vem para um público de Pós-Graduação que 
pode ter menor qualidade do que o público branco. E aí, há um filtro, eles tentam fazer um filtro, porque entende que nem todo mundo tem perfil para pesquisador, para Mestrado e tal, então, quem são os melhores? Então, como isso é um filtro, mas como que vai corrigir essa distorção que há, da população negra é maior, mas a população acadêmica é maior branca ou reflete isso, também, na avaliação CAPES. De repente pode colocar alguma coisa algum critério lá que considere todo esse cenário.

Entrevistado (E3): Eu acho que ela tem que considerar a iniciativa dos Programas e dar ponto por causa da iniciativa. Agora, eu não acredito que vai haver diferença...

Entrevistador: Mas aí não tem números de, quando tem um programa de Pós-Graduação não tem a expectativa, também, e isso reflete na nota do Programa, a quantidade de publicações...

Entrevistado (E3): E isso que eu estou te dizendo, até agora não dá para afirmar que os estudantes que entraram em ações afirmativas vão apresentar o desempenho acadêmico aquém dos estudantes que não assim entraram.

Entrevistador: Então, tanto a CAPES avaliar...

Entrevistado (E3): A CAPES não vai saber quais alunos são de ação afirmativa e quais nãos são. É claro que, ao fim, vai ser uma média, por exemplo, de defesa. Qual foi a média de defesa do Programa nos cursos de Mestrado e Doutorado e depois qual foi a publicação dos estudantes de Mestrado e Doutorado. Não vai ser assim: Publicação de estudantes de ação afirmativa e de não ação afirmativa. Agora, de fato, a gente só pode avaliar isso ao fim de um ciclo de Pós, ao fim dos dois anos de Mestrado dos que entraram esse ano e ao fim dos quatro anos de Doutorado. Qualquer tipo de desconfiança que a gente possa ter é mais preconceito. $\mathrm{Na}$ época da libertação dos escravos, também, se tinha o preconceito se eles seriam disciplinados o suficiente pra assumir trabalho livre, ou seja, contasse as doze horas daquela época em que se trabalhava, se ele chegaria às oito da manhã e sairia às oito da noite. Depois, foi-se ver que isso é uma quimera, que depois os trabalhadores eram iguais a quaisquer outros e faziam a diferença. Tem alguns argumentos que são colocados e que ganham certa projeção que a gente tem que analisar a fundo de onde vem esse argumento. $\mathrm{O}$ argumento da desconfiança, ele só pode ser algo levado realmente a sério, como a gente está colocando, ao fim do ciclo de Pós, ou seja, ao fim de dois anos de Mestrado e ao fim de quatro anos de Doutorado, quiçá, dois e quatro seja realmente efetivo para avaliar uma política como essa, talvez, tenha que se esperar outras turmas entrarem...

Entrevistador: De outros cursos? Juntar a avaliação de outros cursos, também.

Entrevistado (E3): Os outros cursos, outros Programas, etc. Análise política pública é algo muito mais amplo do que nós podemos imaginar com um semestre só de ação afirmativa na Universidade e tem que esperar, então, isso ainda é algo em aberto que tem que se ver. 
Entrevistador: Mas essa informação que você colocou de que a aluna que teve a melhor nota foi negra, que os professores estão percebendo a turma no mesmo padrão das outras antes de haver essa reserva. Então, aponta, mas não dá pra concluir, não é?

Entrevistado (E3): Isso. Não dá para afirmar. Se pudesse pegar uma turma isolada como avaliação da política eu diria que a política foi um sucesso, mas a gente não pode, isso é metodologicamente equivocado. Esperar para, daqui a um tempo, para a gente fazer realmente a análise. As análises que eu tenho lido sobre ações afirmativas na Graduação elas tem apontado para o sucesso da política, por mais que aqui eles tem o IRA menor, mas a inclusão, essas coisas tem sido feitas.

Entrevistador: Se eu não me engano cinquenta e quatro por cento dos alunos não estão fazendo Pós. E quinze fazem Doutorado e um pouquinho mais que isso Mestrado.

Entrevistado (E3): Treze, doze anos atrás, antes das políticas serem implementadas, enfim, eu fiz Mestrado com uma menina negra e eu fiz o Doutorado com uma menina negra, uma só. Então, a gente pode imaginar que tem alguma coisa errada.

Entrevistador: E os Programas dá para ver o potencial, até na Universidade.

Entrevistado (E3): Claro. E você está em qual semestre da Pós?

Entrevistador: No último.

Entrevistado (E3): Tem que defender agora...

Entrevistador: Em dezembro. Estou um pouquinho atrasada.

Entrevistado (E3): Atrasos acontecem. Eu, como coordenador de Pós, eu seria hipócrita em dizer que isso é bom, não é bom, isso é ruim, mas atraso a gente sabe que ocorre.

Entrevistador: Tá bom.

Entrevistado (E3): Bom, sucesso, espero que saia daí uma grande dissertação.

Entrevistador: Obrigada.

Entrevistado (E3): Depois eu queria ter contato com o trabalho final, se possível.

Entrevistador: Claro.

Entrevistado (E3): O programa, quando o aluno não passa na prova de línguas, o estudante não passa, seja ele estudante que está participando de ação afirmativa ou não, a gente dá um 
curso de inglês vez de quinze dias, um curso de reforço, todos os dias, quatro horas diárias. É um curso que dá mais ou menos quarenta horas em que eles fazem as questões que eles não conseguiram responder, a professora dá apoio em problemas específicos que eles tiveram e, depois, ele faz outra prova, tem uma segunda chance. Aí, dependendo do... Ano passado, seis pessoas não foram aprovadas, daqueles aprovados na classificação geral não foram aprovados em língua estrangeira. Aí, depois do curso, cinco foram aprovados, um só que foi reprovado. E não era de ações afirmativas aquele que foi reprovado. Então, a gente acha que o curso, também, que a gente está dando de inglês, de alguma forma, ajuda e esse estudante possa ter sucesso, um bom resultado ao fim do processo.

Entrevistador: Eu não entendi por que que essa nota de corte foi diminuída para cinco para todo público, não é?

Entrevistado (E3): Para todo. Tanto universal, quanto edital de ações afirmativas e todas as fases a nota de corte é de cinco.

Entrevistador: São três fases, que você falou...

Entrevistado (E3): Três fases mais a prova de língua. Primeira fase, projeto; segunda fase, prova escrita; terceira fase, prova oral, entre uma fase e outra, se eu não me engano entre a prova escrita e a prova oral tem a prova de línguas que é eliminatória.

Entrevistador: E isso beneficia não só...

Entrevistado (E3): A todos os estudantes. A única coisa que difere no edital hoje é que o aluno que concorre no edital ação afirmativa, ao fim do processo ele vai está concorrendo com aqueles que concorreram com ação afirmativa. Essa é a única diferença, o processo é igual para todos os grupos.

Entrevistador: E para ser considerado como população negra, qual que é o critério que se usa?

Entrevistado (E3): O critério é a auto definição. A pessoa se inscreve ou não como participante de ações afirmativas. Se declara negro, pardo, aqueles critérios de classificação do IBGE. Tem sido um sucesso, vamos ver a longo prazo. 


\section{ANEXO 1}

Programas sociais incluídos no Plano Pluri Anual 2012-2015

\begin{tabular}{|c|c|c|c|}
\hline & & & $\begin{array}{c}\text { PPA } \\
2012 \div 2015\end{array}$ \\
\hline \multicolumn{4}{|c|}{ PROGRAMA: 2034 - Enfrentamento ao Racismo e Promoção da Igualdade Racial } \\
\hline \multirow{2}{*}{ INDICADORE S } & \multirow{2}{*}{ Unid ade de Medida } & \multicolumn{2}{|c|}{ Referêncin } \\
\hline & & Data & Índire \\
\hline $\begin{array}{l}\text { Núme ro de comunidades quilombolas certificadas - } \\
\text { (Alteração do Indic ador) }\end{array}$ & unidade & $31 / 12 / 2011$ & $1.863,00$ \\
\hline $\begin{array}{l}\text { Núme ro de famílias quilombolas no CadÚnico dos programas } \\
\text { sociais do Gove mo Federal - (A theraç ão do Indir ador) }\end{array}$ & unidade & $31 / 12 / 2011$ & $65.779,00$ \\
\hline \multicolumn{4}{|c|}{$\begin{array}{r}\text { OBJE TIVO: } 0772 \text { - Promover a incorporação da perspectiva da igualdade racial nas políticas } \\
\text { governamentais, articul ando ministérios e demais órgãos federais, estados e municipios. }\end{array}$} \\
\hline \multicolumn{4}{|c|}{ Órgão Responsável: Secretaria de Políticas de Promoção da Igualdade Racial } \\
\hline \multicolumn{4}{|l|}{ Metas 2012-2015 } \\
\hline \multicolumn{4}{|c|}{$\begin{array}{l}\text {-Produzir e difundir publicaçōes e outros instrumentos de orientação que ofereçam suporte à formulação e } \\
\text { monitoramento das políticas de promoção da ig ualdade racial, inclúdo perspectiva de gênero. - (Alteraçâo da } \\
\text { Meta) }\end{array}$} \\
\hline \multicolumn{4}{|c|}{$\begin{array}{l}\text { Froduzir e publicar relatórios periódicos de monitoramento das políticas de promoção da igualdade racial, } \\
\text { inclumindo a perspectiva de gênero - (Meta original) }\end{array}$} \\
\hline \multicolumn{4}{|c|}{$\begin{array}{l}\text { - Realizar ações com órgãos da Administração Publica Federal e com estados e municípios visando à efetivação de } \\
\text { políticas que têm como foco prioritário a populaçăo neg ra. - (Nova Meta) }\end{array}$} \\
\hline \multicolumn{4}{|c|}{$\begin{array}{c}\text { OBJE TIVO: } 0773 \text { - Promover ações afirmativas no âmbito da ação governamental visando a corrigir } \\
\text { as desigual dades raciais e assegurar a igualdade de oportunidades. }\end{array}$} \\
\hline \multicolumn{4}{|c|}{ Órgão Responsável: Secretaria de Políticas de Promoção da Igualdade Racial } \\
\hline
\end{tabular}




\section{Metas 2012-2015}

- Ampliar o núme ro de organizações públic as e privadas que implementam ações afirmativas para a população negra. - (Alteração da Meta)

Construir cadastro de programas de ações afirmativas no âmbito das três esferas de Governo e da iniciativa privada - (Meta original)

OBJE TIVO: 0774 - Disseminar e adotar medidas que garantam a efetividade dos marcos legais referentes ao enfrentamento do racismo e à promoção da igualdade racial.

Órgão Responsável: Secretaria de Políticas de Promoção da Igualdade Racial

\section{Metas 2012-2015}

-Produzir e difundir instrumentos de onentação para implementação dos marcos legais. - (Nova Meta)

OBJE TIVO: 0776 - Instituir medidas de prevenção e enfrentamento do racismo institucional, fomentando a valorização da pluralidade etnicorracial em instituições públicas e privadas.

Órgão Responsável: Secretaria de Políticas de Promoção da Igualdade Racial

\section{Metas 2012-2015}

- Assegurar a inclusão de conteúdos sobre a te mática racial em programas e ações de sensibilização e capacitação de servidores(as) para identificação, abordagem e enfrentamento ao racismo institucional. - (Nova Meta)

OBJE TIVO: 0777 - Reverter representações negativas da pessoa negra, que sustentam as ações de negação simbólica e as diversas formas de violência bem como reconhecer e val orizar a historia e a cultura negra em suas formas de existência e resistência 


\section{Mais Brasil}

Órgão Responsável: Secretaria de Políticas de Promoção da Igualdade Racial

\section{Metas 2012-2015}

-Colaborar para o fortalecimento institucional de organizações negras e sua participação em instâncias de controle social de políticas públicas. - (Alteração da Meta)

Fortalecer organiaç̧ós de midia negra - (Meta original)

- Realizar e apoiar ações elou medidas para a valorização da pessoa negra e para o enfrentamento ao racismo, divulgando as manifestações da cultura, a memónia e as tradições afrobrasileiras. - (Alteração da Meta)

Realizar e apoiar campanhas de valorização da pessoa negra e de enfrentamento ao racismo, divulgando as manifestações da cultura, a memória e as tradiçóes afrobrasileiras - (Meta original)

OBJE TIVO: 0986 - Articular junto aos ministérios e demais órgãos governamentais o acesso de povos e comunidades tradicionais a serviços públicos e programas sociais.

Órgão Responsável: Secretaria de Políticas de Promoção da Igualdade Racial

\section{Metas 2012-2015}

-Criar instrumento de coorde nação e monitoramento para promover o acesso às políticas governamentais pe los povos e comunidades tradicio nais de matriz africana e os povos de culturas ciganas. - (Alteração da Meta)

Implantar sistema integrado de informações sobre as ações governamentais para comunidades de terreiro e powos de culturas ciganas - (Meta original)

\section{Iniciativas}

.0477 - Des envolver coopera̧̧ão com a Fundação Nacional do Índio (FUNAI) estabelecendo linha de parceria em açöes relacionadas à questão indígena - (Exchúda) 
-0478 - Mapeamento e levantamento scciceconônico e de demandas por serviços e programas sociais dos povos e conmudades tradicionais de matriz africana em sua diversidade, bem como acompanhamento de açóes de deservolvimento sus tentável ness as commudades - (Alteraçăo da Iniciativa)

Mapeamento e levantanento socioeconônico e de demandas por serviços e programas sociais das comuridades tradicionais de terreiro em su diversidade, bem como acompanhanento de açöes de desenvolvimento sustentável nessas commidades - (Titulo origind)

-0479 - Articulação com Irstituiọões que tem oomo finalidade a preservação do patrimônio Histórico, Artís tico e Cultural para deservolvimento de açóes específicas junto aos powos e comunidades tradicionais de matriz africana. (Aleraçăo da Iniciativa)

Proposição de modalidade de tombamento que considere as variadas dimensöes que compõem o patrimôrio imaterial inerente à combnidades tradicionais de terreiro e acompanhamento dos processos de tombamento. salvagurda registro dou inventário do patrimôno dess as comunidades - (Título original)

.04DX - Apoio ao deserrolvimerto sustentável dos povos indígenas, comuridades quilombolas e outros povos e comunidades tradicionais visando à marntenção e à dispornb ilidade dos recurs os naturais em seus terniónios, necessários a sua reprodução culturale segurança alimentar e mutricional, bem como incentivar o fortalecimento das organizações comuritárias, qualificando e ampliando o acesso às políticas públicas, com êrfase nos serviços, infraestnutura social e acess bi ilidade e a participação nos espaços de gestão púb lica, mediarte articulação de parcerias com instituiçóes públicas e privadas, vis ando ao etrodesenvolvimento desses powos e comuridades (Nova Iniciativa) 


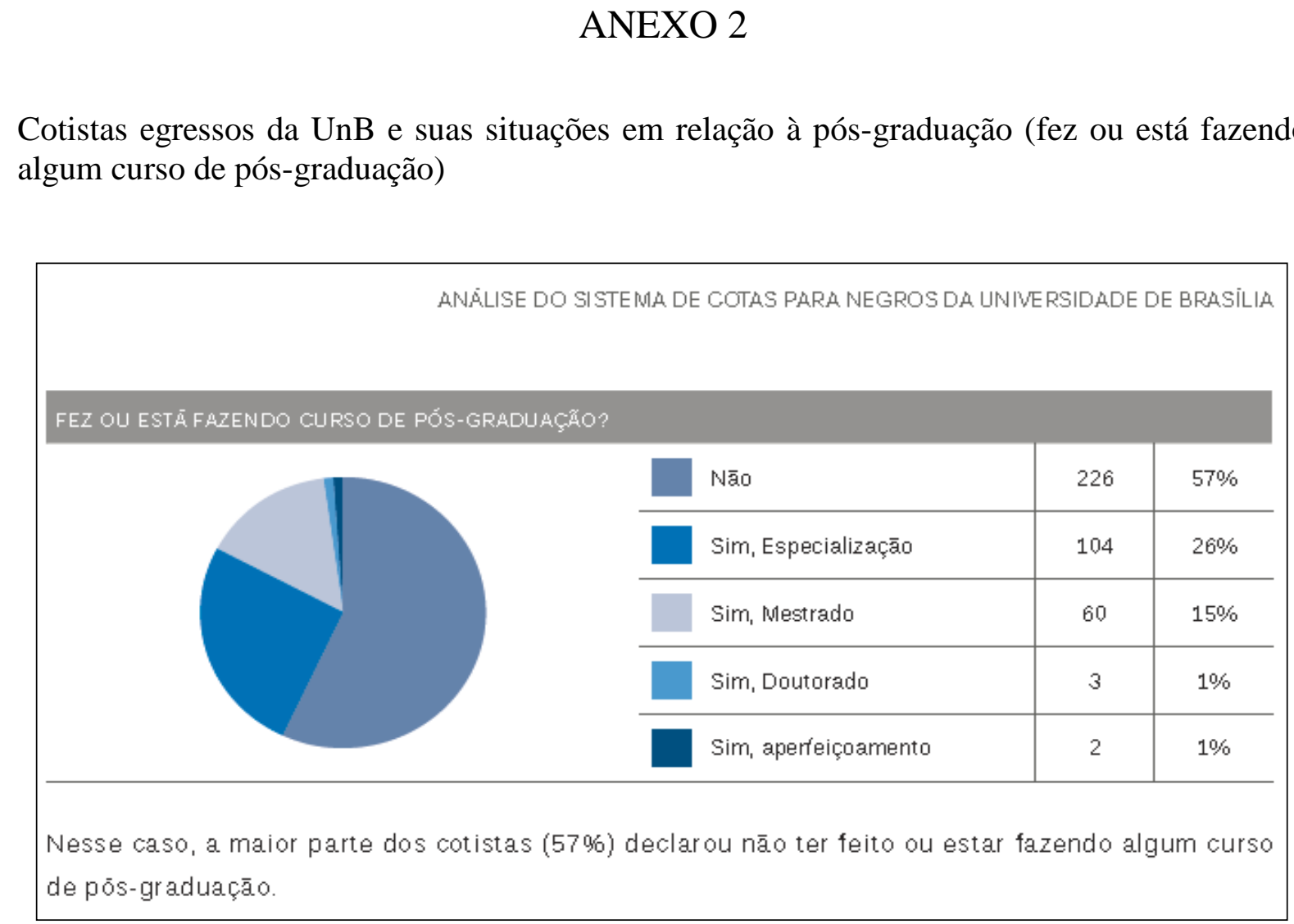

Fonte: UnB (2013) 